University of Louisville

ThinkIR: The University of Louisville's Institutional Repository

Electronic Theses and Dissertations

$5-2014$

\title{
An analysis of the Creation Museum : hermeneutics, language, and information theory.
}

Steven Mark Watkins

University of Louisville

Follow this and additional works at: https://ir.library.louisville.edu/etd

Part of the Arts and Humanities Commons

\section{Recommended Citation}

Watkins, Steven Mark, "An analysis of the Creation Museum : hermeneutics, language, and information theory." (2014). Electronic Theses and Dissertations. Paper 1536.

https://doi.org/10.18297/etd/1536

This Doctoral Dissertation is brought to you for free and open access by ThinkIR: The University of Louisville's Institutional Repository. It has been accepted for inclusion in Electronic Theses and Dissertations by an authorized administrator of ThinkIR: The University of Louisville's Institutional Repository. This title appears here courtesy of the author, who has retained all other copyrights. For more information, please contact thinkir@louisville.edu. 


\title{
AN ANALYSIS OF THE CREATION MUSEUM: HERMENEUTICS, LANGUAGE, AND INFORMATION THEORY
}

\author{
By \\ Steven Mark Watkins \\ B.A., Northern Kentucky University, 1996 \\ M.Div., The Master's Seminary, 2000
}

\begin{abstract}
A Dissertation Submitted to the Faculty of the College of Arts and Sciences of the University of Louisville In Partial Fulfillment of the Requirements for the degree of
\end{abstract}

Doctor of Philosophy

Department of Humanities

University of Louisville

Louisville, Kentucky

May 2014 
Copyright 2014 by Steven Mark Watkins

All rights reserved 



\title{
AN ANALYSIS OF THE CREATION MUSEUM: HERMENEUTICS, LANGUAGE, AND INFORMATION THEORY
}

\author{
By \\ Steven Mark Watkins \\ B.A., Northern Kentucky University, 1996 \\ M.Div., The Master's Seminary, 2000
}

A Dissertation Approved on

March 21, 2014

by the following Dissertation Committee:

Dissertation Director

Mary Ann Stenger

Tatjana Soldat-Jaffe

Osborne Wiggins

James Bielo 


\section{DEDICATION}

This dissertation is dedicated to my wife

Andrea Susanne Watkins

without whose support this dissertation would never have happened. 


\section{ACKNOWLEDGEMENTS}

I want to express my deepest gratitude and thanks to my mentor and professor, Mary Ann Stenger, for her confidence in me and her continual guidance to shape me into a better scholar. I would also like to express heartfelt thanks to my committee members at the University of Louisville, Tatjana Soldat-Jaffe and Osborne Wiggins-I cannot imagine a better, more supportive, or smarter committee anywhere. I owe a deep thanks to my outside reader, James S. Bielo, of Miami University (Ohio) for his mentorship as well as his friendship — thanks too, James, for teaching me so much about ethnography. While these four scholars have improved this dissertation vastly, I remain solely responsible for any errors or inaccuracies that this work might contain. Thanks to Tim Gombis for his loyal friendship and faith in me. I would also like to thank a list of scholars who have helped and shaped me in profound ways: David Aaron, John Alberti, Annette Allen, Pamela Beattie, Doug Hume, Denis O. Lamoureux, David E. Long, Elizabeth Patton, Pat Pranke, Mark C. Taylor, Bill and Sue Trollinger, Amy Tudor, David Vinson, Julie Marie Wade, Lindsey Walters, Mark Williams, and Elaine O. Wise. Special thanks to Renee Culver, Angie Griffin, James Leary, Lynda Mercer, Carol Stewart, Katherine Wagner, and Ben Wilt. Dr. And Mrs. Jim Ramage have supported and helped our family in so many ways that I cannot imagine completing this task without them. My parents, Ed and Judy Watkins, have been a source of inspiration in so many ways by their constant demonstration of love for me. I saved the most important 
expression of thanks for last—-thank you with all my heart, Andrea, for your ceaseless love and encouragement. I hope my dissertation, in some small way, measures up to yours. 


\begin{abstract}
AN ANALYSIS OF THE CREATION MUSEUM: HERMENEUTICS, LANGUAGE, AND INFORMATION THEORY
\end{abstract}

Steven M. Watkins

March 21, 2014

This dissertation analyzes the Creation Museum in Petersburg, Kentucky with respect to hermeneutic, linguistic, and information theories. The popularity of the CM, with an excess of 1.6 million visitors to date and future plans to build a one-hundred million dollar theme park, raises concerns among religious and non-religious people. The $\mathrm{CM}$ has drawn the attention of all the major news networks and has been reported on extensively in print media. The number of visitors and money raised by the CM dwarfs other museums in the area with large federal endowments. This dissertation draws the interest of popular educated audiences as well as scholars.

The dissertation is divided into five main chapters. Chapter I surveys the relevant literature on creationism in the United States. Chapter II defines the use of three theoretical fields - hermeneutics, linguistics, and information theory - to analyze the operational logic of the CM. Chapter III uses aspects of Hans-Georg Gadamer's ideas of interpretive horizons to demonstrate how the CM justifies a selective and literal interpretation of Genesis 1. Chapter IV applies Norman Fairclough's theory of Critical Language Study (CLS) to the various structures that project an authoritative form of discourse at the CM. Chapter V uses theories put forth by Mark C. Taylor to explain how 
information is processed in terms of screening - a phenomenon that seeks to reify an ancient myth. Taylor's definition of religion as a complex adaptive network also illustrates why science is such a threat to the $\mathrm{CM}$ and why efforts are made to redefine science.

The primary sources of evidence used include museum exhibits, literature published by the CM, videos, and ethnographic interviews. The interviews are semistructured and allow for clarification and elaboration.

The central conclusion is that the CM is a fundamentalist organization that rigorously maintains biblical inerrancy as an interpretive principle. Moreover, it employs a closed hermeneutic approach that I have identified as "concordism." Authority is established through a discursive use of academic frames (contexts) and scripts (individual roles). The $\mathrm{CM}$ also displays certain features of complex adaptive networks as it reacts to a wider set of epistemological domains. 
TABLE OF CONTENTS

PAGE

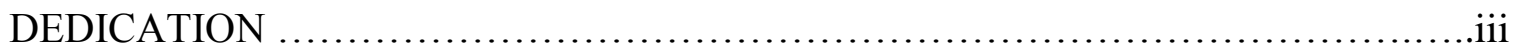

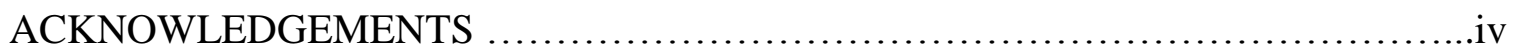

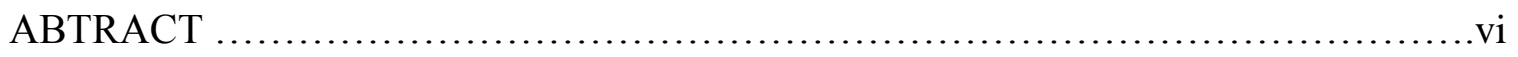

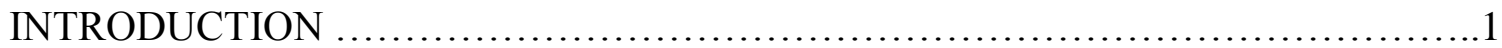

CHAPTER I

REVIEW OF LITERATURE $\ldots \ldots \ldots \ldots \ldots \ldots \ldots \ldots \ldots \ldots \ldots \ldots \ldots \ldots \ldots \ldots \ldots \ldots \ldots$

CHAPTER II

THEORIES PERTAINING TO AN ANALYSIS

OF THE CREATION MUSEUM ........................................................

CHAPTER III

THE CONSTRUCTED NARRATIVE: THE EPISTEMOLOGICAL BASE

AND A MODERN INTERPRETIVE HORIZON .................................83

CHAPTER IV

EVIL EXPLAINED: THE CAUSE AND SOLUTION TO CORRUPTION ...........134

CHAPTER V

SCIENCE REDEFINED: WHY A MUSEUM .....................................184

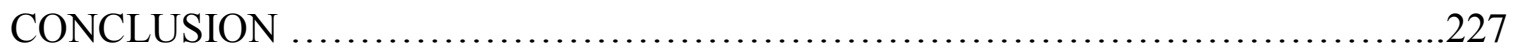

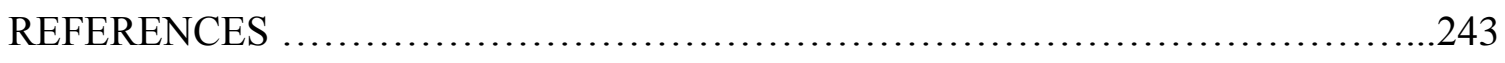

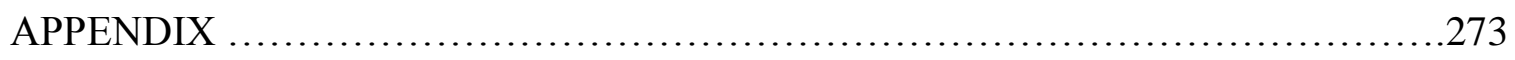

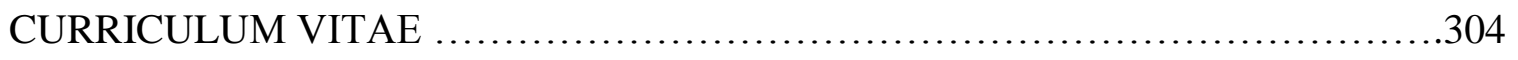




\section{INTRODUCTION}

The central thesis for my dissertation proposal is that the Creation Museum (CM) offers a fundamentalist interpretation of the Bible which purports to be a corrective to various social problems of modern society. This main hypothesis gives rise to several key premises for research: first, the $\mathrm{CM}$ taps into societal anxiety through the presentation of images such as natural disasters, starvation, drug abuse, and other pejorative aspects of the world. Second, these ills are then connected to human sinfulness as portrayed in a literalistic account of human transgression in the Garden of Eden. Having eaten the forbidden fruit, Adam and Eve doomed humanity to all forms of evil on earth—physical and moral. Third, the corrective for transforming the world is to be found in applying a literal interpretation of the Bible and thus recovering a more "godly" society and world.

Fundamentalism formed in the early twentieth century as a reactionary movement against modernist, biblical criticism. As a North American Protestant movement, early fundamentalists were reacting to what they perceived as an attack by biblical critics on the Bible. The primary focus in early fundamentalist writing dealt predominantly with the rejection of higher biblical criticism, the divinity of Christ (including the miraculous conception, physical resurrection, and miracles), and the inerrancy and inspiration of the Old and New Testaments. ${ }^{1}$ However, the specific issues that fundamentalists oppose have varied through the years. The single theological issue which has remained constant for

\footnotetext{
${ }^{1}$ The title of the four volume original work which deals with the specific issues mentioned above, became the term that would stand for the movement itself-The Fundamentals. R. A. Torrey and A. C. Dixon et. al. eds. The Fundamentals: A Testimony to the Truth. Vols. I and II. (Grand Rapids: Baker Books, 1917 [Reprint 2008]).
} 
fundamentalists has been a rigorous defense of biblical inerrancy. Other moral, social, scientific, and theological issues have varied. My study of fundamentalist cultures has yielded the following definition that I will use throughout this project: "Fundamentalism is a reactive religious movement that seeks to establish a pure religious order of society through born-again conversion/salvation. The inerrancy of the Old and New Testaments (not including the Apocryphal writings) is a non-negotiable presupposition."2

Following the basic tenets listed above, fundamentalist cultures of all types tend to develop similar dynamics. Such dynamics include, but are not limited to: authoritarian leadership by a charismatic individual, a dualistic or binary view of the world as divided sharply between good/evil, the subjection of women or what I will refer to later as "patriarchalism," and an effort to set boundaries which separate insiders (the godly) from outsiders (the secular or worldly). ${ }^{3}$ These dynamics shift in their proportions depending upon the particular variety of fundamentalist culture.

Another common denominator of the $\mathrm{CM}$ and fundamentalism is a strong reaction to the growing complexities of network society and globalization. I will explain in more detail below how "information theory" contributes to destabilization and its connection with fundamentalism. Here I would simply assert the connection between the fundamentalist impulse to react to modernization by attempting to return to a more stable time/place — as if such a return were even possible. At least four scholars have

\footnotetext{
${ }^{2}$ Inerrancy is the doctrine that the Bible is the supreme word of God and as such it contains no errors - scientific, historic, or otherwise.

${ }^{3}$ These aspects have been thoroughly documented in the following sources: George Marsden, Fundamentalism and American Culture (Oxford: Oxford University Press, 2006) and Martin E. Marty and R. Scott Appleby, The Glory and the Power: The Fundamentalist Challenge to the Modern World (Boston: Beacon Press, 1992) and Gabriel A. Almond, R. Scott Appleby, and Emmanuel Sivan, Strong Religion: The Rise of Fundamentalisms around the World (Chicago: The University of Chicago Press, 2003).
} 
documented this tendency_-Manuel Castells, Olivier Roy, Peter Berger, and Mark C. Taylor. 4

Young Earth Creationism (YEC) has become a significant part of North American Protestant fundamentalism. This assertion will be one focus of my research which I will discuss at length. Here, I will simply refer to Arthur McCalla's book as a recent source that identifies YEC as one variety of fundamentalism. ${ }^{5}$

One important feature of fundamentalism is the presence of a charismatic leader. These leaders are often extremely persuasive public speakers. Language is the primary medium used by charismatic leaders as they construct and maintain fundamentalist enclaves. The leading spokesperson for YEC is Ken Ham, founder, President and CEO of Answers in Genesis (AIG). ${ }^{6}$ AIG is the parent organization that built the Creation Museum in 2007. Ham fits the profile of a charismatic leader and has become the single most popular voice in YEC. Ham's language includes typical fundamentalist forms such as literalism, either/or dichotomies, and emotive appeals. ${ }^{7}$ But his language also includes innovative features such as the supplemental use of visual imagery and technology to bolster his verbal and written arguments.

\footnotetext{
${ }^{4}$ Manuel Castells, The Rise of the Network Society, Vol. 1 of The Information Age: Economy, Society, and Culture, $2^{\text {nd }}$ ed. (Malden, MA: Wiley-Blackwell, 2010); Olivier Roy, Holy Ignorance: When Religion and Culture Part Ways, trans. Ros Schwartz (New York: Columbia University Press, 2010); Mark C. Taylor, After God (Chicago: The University of Chicago Press, 2007); Peter Berger and Anton Zijderveld, In Praise of Doubt (New York: Harper One, 2009).

${ }^{5}$ Arthur McCalla, The Creationist Debate: The Encounter Between the Bible and the Historical Mind (New York and London: Continuum, 2006).

${ }^{6}$ Randall J. Stephens and Karl W. Giberson, The Anointed: Evangelical Truth in a Secular Age (Cambridge, MA: Harvard University Press, 2011), 11.

${ }^{7}$ The following sources have documented such use of language: Nancy Tatom Ammerman, Bible Believers: Fundamentalists in the Modern World (New Brunswick, NJ: Rutgers University Press, 1987); Kathleen C. Boone, The Bible Tells Them So: The Discourse of Protestant Fundamentalism (London: SCM Press, 1989); and Susan Friend Harding, The Book of Jerry Falwell: Fundamentalist Language and Politics (Princeton, NJ: Princeton University Press, 2000).
} 
The CM is the culmination of Ham's innovations of over twenty years. In addition to more traditional forms of communication (speaking to conferences and church groups, as well as publishing books and magazines), Ham's construction of the CM has been successful in maintaining a narrow and selectively literal interpretation of Genesis 1 in addition to maligning both science and mainstream biblical scholarship. Ham alone oversees the tight sequence of arguments presented at the CM. My analysis will include sources from Ham's writings, CM publications, video presentations, website postings, museum displays, and imagery, as well as ethnographic interviews of key CM staff. Analysis of the CM, the topic for this dissertation, requires an interdisciplinary approach. Scientists (especially geologists, biologists, and paleontologists) must also contribute for a full critique of the CM and these analyses are obviously beyond my capability. In some cases, where scientific issues appear to be obvious, I will raise a few tentative questions but will leave the fuller critique to scientific experts. My interdisciplinary approach is required because the $\mathrm{CM}$ mixes visual, linguistic, and hermeneutic approaches in an effort to explain the current world. For example, a visitor walking from one exhibit to the next is transported from the Garden of Eden to Pol Pot's Cambodia and Hitler's Germany. In such a transition from the Garden to the "Cave of Sorrows," interpretive audio and visual images bombard the viewer in a rapid, staccato fashion.

The popularity of the CM, with an excess of 1.6 million visitors to date and future plans to build a multi-million dollar theme park, raises concerns among religious and 
non-religious people throughout the country. ${ }^{8}$ The CM has drawn the attention of all the major news networks and has been reported on extensively in print media. ${ }^{9}$ This project will draw the interest of popular educated audiences as well as scholars. Articles on the $\mathrm{CM}$ have appeared in publications such as Vanity Fair and Curator Magazine as well as the popular books, Rapture Ready by Daniel Radosh, and Why People Believe Weird Things by Michael Shermer. ${ }^{10}$ Interest from professional anthropologists, sociologists, educators, religious studies scholars, and scientists are documented in the Review of Literature (Chapter I).

This project also addresses aspects of the political and cultural concern in American society. The number of visitors and money raised by the CM dwarfs other museums in the area with much larger federal endowments. ${ }^{11}$ Evolutionary scientist and Christian, Asa Gray, delivered a lecture to a theology class at Yale University in 1880. In that lecture he made an important statement. He noted that there was a time, "when schemes for reconciling Genesis with Geology had an importance in the churches, and among thoughtful people, which few if any would now assign to them." 12 This statement is striking when contrasted with several polls that place a large percentage of Americans

\footnotetext{
${ }^{8}$ The first phase of the Ark Encounter is estimated to cost seventy-three million dollars with later phases putting the park at well over one-hundred million dollars. Answers in Genesis, http://www.answersingenesis.org/articles/ark/ark-bond-offering-succeeds (accessed March 5, 2014). its website.

${ }^{9}$ The CM's parent organization (Answers in Genesis) lists the programs and articles published on

${ }^{10}$ Daniel Radosh, Rapture Ready: Adventures in the Parallel Universe of Christian Pop Culture (New York: Scribner, 2008); and Michael Shermer, Why People Believe Weird Things: Pseudoscience, Superstition, and other Confusions of Our Time (New York: St. Martin's Griffin, 2002).

${ }^{11}$ One example is the National Underground Railroad Freedom Center in Cincinnati, Ohio. Since opening in 2004, this one-hundred-and-ten million dollar facility has cut staff in half and was threatened with closure in 2012 because of a one-and-a-half million dollar shortfall. Meanwhile the CM has drawn far more visitors and money, despite the lack of federal funding.

${ }^{12}$ Quoted in Edward B. Davis, "The Word and the Works: Concordism in American Evangelical Thought," Klaas Van Berkel and Arjo Vanderjagt eds. The Book of Nature in Early Modern and Modern History (Leuven, Belgium: Peeters, 2006), 202 [emphasis mine].
} 
(somewhere in the mid-40\% range) as not believing in evolution. ${ }^{13}$ Even if the polls are off to some degree, it is striking that Gray's confidence in 1880 has seemingly gone in the opposite direction for large segments of American society. Moreover, the early fundamentalists (1900 to 1925) held overwhelmingly to a creationism that was old-earth and evolutionist in nature.

The following list of questions is based on preliminary research that I have conducted at the CM. In what ways has the CM structured a cohesive but revisionist/concordist biblical narrative in the architecture, exhibits, and media forms present at the museum? Has the CM become one of the new movements within fundamentalism? What aspects of fundamentalism have remained the same in YEC? How does the CM use language, interpretation (hermeneutics), and imagery to uphold biblical literalism? To what degree are the portrayals of evolutionary science at the CM accurate? How is information "screened" and controlled at the CM? Are there shared demographic connections among visitors at the CM (political, denominational, educational, ethnic)? What are the core premises that enable the CM's position to be understood and accepted? In what ways does the CM manifest the dynamics of a complex adaptive network?

This dissertation differs from previous publications in several ways. First, no single, comprehensive analysis of the CM has been conducted by a scholar. Previously published materials by scholars amount to several chapters and a few articles, and all but one of these articles have come from scientists. To my knowledge, a dissertation length

13 John D. Miller, Eugenie C. Scott, Shinji Okamoto, "Public Acceptance of Evolution," Science (August 2006), 765-6, as referenced in Kenneth R. Miller, Only a Theory: Evolution and the Battle for America's Soul (New York: Viking, 2008), 214. Miller uses a pole taken from and cited in a 2006 article in Science magazine. Gallup polls are pretty much consistent with the statistics above: http://www.gallup.com/poll/114544/Darwin-Birthday-Believe-Evolution.aspx 
analysis of the CM has not been completed on the Ph.D. level. Second, an interdisciplinary approach has not been applied to the overall structure of the CM. My application of linguistics, hermeneutics, and information theory will be the first attempt to show the interconnections from these humanitarian disciplines. Third, humanitarian disciplines such as those used in my dissertation have not been applied in any comprehensive analysis.

Based on my research, I show how the pre-patriarchal narratives (Genesis 1-11) are used to support a YEC version of history and science. The CM attempts to connect these Genesis narratives with certain New Testament doctrines of theology-especially doctrines pertaining to Christology, soteriology, and hamartiology. My research also shows how these connections are both selective examples of "screening information" and a hermeneutical approach that provides justification for the historical-literal reading of the pre-patriarchal narratives. The connections are made linguistically through frames, scripts, and schemata that fit a particular religious worldview. ${ }^{14}$

What is essentially provided at the CM is a web of images, language, and texts that form an argument held together with one primary premise-biblical inerrancy. There is a great deal of vacillation between the creation story (mostly Genesis 1), the fall of humanity (Genesis 3), the story of Noah's flood (Genesis 6-9), and a division of race/ethnicity in the Tower of Babel story (Genesis 11). Literalizing these separate, pre-

\footnotetext{
${ }^{14}$ I will use Norman Fairclough's definitions of frames, scripts, and schemata (defined below) to connect the language of the CM with the religious worldview I see as necessary in order for YEC to appear as cohesive.
} 
patriarchal (or primeval) narratives, the $\mathrm{CM}$ has established an explanatory framework for the interpretation of the modern world. ${ }^{15}$

The CM bases its explanation around the following three themes. First is the assertion that there is only one correct reading of the Bible-which is the inerrant word of God. Second, it attempts to account for and to provide a corrective for a wide variety of social "problems" — racism, drug, abuse, suicide, euthanasia, homosexuality, abortion, and pornography are the most commonly named problems. Third, it proposes a substitute for scientific evolutionary theory by attacking mainstream science and by offering its own pseudoscience as a substitute.

Ironically, one of the two main goals of the CM, to evangelize, has likely been among its least successful outcomes. ${ }^{16}$ My hypothesis is that the museum's logic does not usually work for visitors who do not hold to the doctrine of inerrancy — religious or nonreligious. My research will demonstrate how these arguments are presented. While they are basically summarized in the three main theses above, they are mixed together in a cacophony of multi-sensory images, statements, and narrative structures.

${ }^{15}$ This explanatory framework is understood by YEC and the CM to be an absolute and universalist concept. As Olivier Roy has argued, one variety of fundamentalism is a universalist position that actually sees itself as a-cultural — somehow having transcended culture altogether, as if that were possible. Olivier Roy, Holy Ignorance: When Religion and Culture Part Ways, trans. Ros Schwartz (New York: Columbia University Press, 2010), 30-33.

${ }^{16}$ I base this assertion on an informal conversation with a high-level staff member who I wish to keep anonymous. Further, the original design at the CM's opening in 2007 contained a chapel (as seen in Map 2, Appendix A), the chapel was turned into a Children's Reading Room because, according to the same source, people hardly ever went into the chapel. The intended purpose of the chapel was to counsel and witness to people who wanted to "be saved." 


\section{CHAPTER I}

\section{REVIEW OF LITERATURE}

The Creation Museum (CM), and its larger, umbrella organization Answers-inGenesis (AIG), is the largest and most successful Young Earth Creationist (YEC) organization in the world. While there are a number of other creationist positions within Christianity, the CM holds to the most extreme end of the spectrum which espouses that creation took place a mere six-thousand years ago. The CM adamantly opposes all other Christian views on creation and insists that the YEC interpretation is the only position established in the Bible. The YEC literature produced by the CM under the imprint Master Books, along with other print and web sources, will serve as the primary sources for analysis in the dissertation.

Because YEC is a relatively recent phenomenon, the literature addressing the subject has been especially prolific in the past two decades. This chapter will review the pertinent literature on YEC from three different perspectives. First is peer reviewed academic literature which is overwhelmingly critical of creationism in general and is especially critical of YEC. The second area will review literature coming from evangelicals who address creationism. Here the literature is a mixture of criticism of YEC and sympathy to some shared religious points of view. The third category of literature is a brief survey of critical biblical commentaries on Genesis.

Before focusing in on YEC, it would be helpful to mention the different creationist positions from the start. Some of the terminology is used inconsistently at 
times, but the following categories are generally agreed upon by scholars. "Creationism" has a wide range of adherents. Some creationists are fully credentialed scientists who are both Christians and committed evolutionists. ${ }^{17}$ Denis O. Lamoureux refers to this position as "evolutionary creation"- - the title of his book. ${ }^{18}$ One unifying feature I have noted among this group is the rejection of "concordism." Lamoureux defines concordism as, "a method of biblical interpretation that seeks to find a correspondence between science and scripture." ${ }^{19}$ Several scholars have used the term "concordism" to describe this fallacious approach to both science and to biblical interpretation. ${ }^{20}$ Concordism is the issue that separates elocutionary creationism from the other main forms of creationism, to be discussed below. "Theistic Evolution" is virtually the same position as Lamoureux's "Evolutionary Creationism." Basically, it tends not to impose any biblical reading upon science, but leaves science alone to draw its own conclusions using methodological naturalism. But they in no way equate methodological naturalism with philosophical materialism. $^{21}$

On the other side of the creationist divide are concordist approaches to science and scripture. Generally they are divided between "Young Earth Creationists" and "Progressive Creationists." The major differences here are assumptions about the age of

\footnotetext{
${ }^{17}$ Among these scholars are: Karl Giberson, Francis Collins, Denis O. Lamoureux, John Polkinghorne, Simon Conway Morris, and others.

${ }^{18}$ Denis O. Lamoureux, Evolutionary Creation: A Christian Approach to Evolution (Eugene, OR: Wipf and Stock Publishers, 2008). I will discuss Lamoureux's writings in more detail in the section on evangelical scholarly literature.

${ }^{19}$ Ibid., 14.

${ }^{20}$ Stanley L. Jaki, Denis O. Lamoureux, and Edward B. Davis.

${ }^{21}$ By "methodological naturalism," I mean the scientific methods of dealing with natural causes and effects. Further, methodological naturalism is the empirical approach that drives scientific experimentation on any and all physical matter. "Philosophical materialism" is a position of belief in only physical matter and no supernatural deity. My point is that methodological naturalism, as a scientific method of inquiry, should not be equated with a commitment to materialism because it does not deal with supernatural investigations. This is essentially the same point made by Stephen Jay Gould in "Nonoverlapping Magesteria," Natural History 106 (March 1997): 16 ff.
} 
the earth and the degree to which evolutionary change has occurred. YEC accepts an earth no older than 10,000 years. The CM prefers a date no older than 6,000 years. Thus, for YECs evolution could not possibly have taken place because of the time required to explain the great geological epochs and adaptations in species. Six thousand years is not nearly enough time for evolution to have occurred. Progressive Creationists have numerous views on the age of the universe and on evolution itself. For example, many Progressive Creationists (some of whom are also referred to as "Intelligent Design" proponents) take a mainstream view of the age of the earth (4.5 billion years) and universe (14 billion years). They also allow for evolutionary change, yet there are different positions as to what role God plays in the process.

\section{Peer Reviewed Literature on Young Earth Creationism}

Peer reviewed literature that addresses YEC has been published mainly by university presses and usually appears in larger works addressing all forms of “creationism." The most comprehensive work to date is Ronald L. Numbers' The Creationists. $^{22}$ First published in 1992, this four-hundred fifty-eight page work surveys the major figures in creationism from the mid-nineteenth century until the early 1990s. Numbers explains the connection between early fundamentalists and creationism as a changing concept through the twentieth century. In the early decades of the twentieth century, many fundamentalists saw no problem with evolutionary theory. At that time, even the majority of fundamentalist scholars held to either a theistic evolutionary position

\footnotetext{
${ }^{22}$ Ronald L. Numbers, The Creationists: The Evolution of Scientific Creationism (Berkeley: University of California Press, 1992).
} 
or to the Gap Theory. ${ }^{23}$ But George Frederick Wright (1838-1921) wrote a chapter in The Fundamentals entitled "The Passing of Evolution." 24 Wright was the first fundamentalist to argue against both theistic evolutionary positions as well as anything materialistic.

Numbers documents the anti-evolutionary crusade up to the time of William Jennings Bryan (1860-1925), culminating in the famous Scopes Monkey Trial in $1925 .^{25}$ As a result of the embarrassment that creationists faced at the Scopes Trial, much of fundamentalism retreated to found their own independent institutions such as Bible colleges, seminaries, and para-church training ministries. Both George Marsden and Numbers identify World War I as a turning point for fundamentalist views against evolution. The horrors of the war created a "cultural crisis." Bryan connected cultural decay - in his case fascist government powers and moral laxity among college studentswith Darwinism and evolution. ${ }^{26}$

Numbers identifies George McCready Price (1870-1963) as the initial pioneer of what came to be YEC. Price, a Canadian, Seventh Day Adventist began writing his interpretations of geology based on the prophetic visions of Ellen G. White (1827-1915), an Adventist leader and prophetess. The idea started with several basic premises from White. A six, twenty-four hour day period of special creation, a global flood as told in the

${ }^{23}$ The Gap Theory was a concordist approach that allowed for a vast period of time between Genesis 1 verse one and verse two. Popularized in The Scofield Study Bible, the note of commentary by Scofield reads, "The first creative act ["In the beginning God created the heavens and the earth."] refers to the dateless past, and gives scope for all the geologic ages." The Scofield Study Bible, Containing the Old and New Testaments: The Authorized Version. Edited by C. I. Scofield (New York: Oxford University Press, 1917 Reprint, 1996), 3.

${ }^{24}$ George Frederick Wright, "The Passing of Evolution," in R. A. Torrey, R. A. and A. C. Dixon et. al. eds. The Fundamentals: A Testimony to the Truth. Vol. II. Grand Rapids: Baker Books, 1917 (Reprint 2008), 72-87. The chapter was originally titled "Evolution from the Christian Point of View."

${ }^{25}$ Numbers does not give a full account of the Scopes trial. A definitive scholarly source for the Scopes Trial is Edward J. Larson's Summer of the Gods: The Scopes Trial and America's Continuing Debate over Science and Religion (Cambridge, MA: Harvard University Press, 1997) .

${ }^{26}$ Numbers makes these observations (Ibid., 41-2) as does Marsden. George M. Marsden, Fundamentalism and American Culture (Oxford: Oxford University Press, 2006), 143-9. 
Noah narratives, and a 6,000 year chronology of earth history offered by Archbishop James Ussher (1581-1656). With these premises, Price used a version of Noah's flood as the catastrophic, global event responsible for explaining the many rock layers and fossils that we find today. This was the beginning of young earth catastrophism which would grow into the current YEC movement.

The largest portion of Numbers' book deals with the rise of catastrophism beginning with Price and taking full form with two of the most influential YECs in the twentieth century-Henry M. Morris (1918-2006) was a hydrologic engineer who coauthored The Genesis Flood: The Biblical Record and its Scientific Implications. The other author, John C. Whitcomb (b. 1924), is a fundamentalist theologian who worked with Morris to co-author the most influential single book on YEC. Numbers documents the influence of Price on Morris and Whitcomb. ${ }^{27} \mathrm{He}$ also explains how Morris and Whitcomb added new sophistication to Price's original ideas. Most significant is the rising popularity of The Genesis Record among evangelicals and fundamentalists in the late 1960s and early 1970s. Also founded in this time period was the San Diego based Institute for Creation Research (ICR) by Morris.

One last aspect of Numbers' work that should be mentioned is his coverage of the establishment of the American Scientific Affiliation (ASA) in 1941. The ASA is a group of scientists and other scholars who take varying views on evolution, but who are supportive of both theistic and progressive creationist points of view. In other words, they all hold to some form of evolutionary creation. The organization sought to teach evolutionary ideas that were complementary with evangelical Christianity. The ASA

\footnotetext{
${ }^{27}$ I am planning to interview Dr. Whitcomb as part of my ethnographic analysis and he has agreed to the interview. One question will be directed at the influence of George McCready Price on Whitcomb and the late Dr. Morris.
} 
continues to provide scientific papers on aspects of evolution from a Christian point of view, but the ASA is opposed to YEC and most other concordist approaches to the biblical and scientific interpretation.

Since the publication of Numbers' The Creationists, a number other important peer-reviewed books have commented on the development of YEC. The first book published after The Creationists was by anthropologist Christopher P. Toumey. His book, God's Own Scientists: Creationists in a Secular World, was based on five years of ethnographic work conducted in the realm of YEC. ${ }^{28}$ Toumey documents the growing popularity of YEC in North America, even among college-educated adults. The book explores the pioneering work of Whitcomb and Morris and it delves into the reasons why YEC becomes powerful for true believers. Toumey identifies evolution as the culprit of the evils of modern society for YEC believers. Additionally, Toumey shows how important the connections are for YECs between evolution, secular humanism, and societal problems. ${ }^{29}$ The book presents an overall argument for the YEC understanding of the world, or "worldview," for lack of a better term.

Toumey's summary statement in the closing pages of his book identifies a similar phenomenon that I have hypothesized concerning the CM. Although Toumey was looking at a group of YECs in North Carolina in the early 1990s, I have found the following statement to be applicable to the CM:

\footnotetext{
${ }^{28}$ Christopher P. Toumey, God's Own Scientists: Creationists in a Secular World (New Brunswick, NJ: Rutgers University Press, 1994).

${ }^{29}$ The term "secular humanism" is used by the CM in a most pejorative sense. Ken Ham uses "secular humanism" as a catchall phrase to refer to godlessness, atheism, nihilism, moral relativism, and elocutionary theory. Christopher Toumey has also discussed this demonizing of secular humanism in another book titled Conjuring Science: Scientific Symbols and Cultural Meanings in American Life (New Brunswick, NJ: Rutgers University Press, 1996).
} 
The creationism of the local activists is much more than a model, a theory, or a strategy. It is the existential stuff of their lives, the glue that binds together all the disparate selves of a self-respecting scientist or engineer, a righteous Christian, a dutiful parent, and a good citizen. Their creationism makes them whole. It is the thing that, to them, makes a person all those things at once, and all for the same reason. It is, for them, a personal way in which science makes sense morally. ${ }^{30}$

I would add to Toumey's description that for the true believers of the CM, all of those parts are not only components of their personal identity, but are the essential aspects of what they believe is true Christianity - all other forms of Christianity range from somewhat corrupt to heretical. This concept will be explored more in my research.

Simon Coleman and Leslie Carlin co-edited a collection of essays on creationism in English-speaking countries. ${ }^{31}$ Of importance for my research are two chapters in particular. The first, written by Simon Coleman, is the Introduction. Coleman provides an analysis of the epistemological issues connected to creationism. He writes, "Making a case for creationism plugs into a wider construction of identity that seeks restoration of lost cultural and intellectual authority." 32 The statement above is one reason why I judge YEC to be fundamentalist in nature. For example, much of the language at the CM alludes to restoring authority for the culture at large. Coleman also suggests that creationism is far more about "a discourse (or set of discourses) embodied in religious practices whose relevance to the evangelical life go far beyond debates about Genesis."33 Such a conclusion confirms my own investigations of the CM and their efforts to create a cohesive set of explanations for why the world is the way that it is. In-depth analysis of

${ }^{30}$ Toumey, God's Own Scientists, 264-65.

${ }^{31}$ Simon Coleman and Leslie Carlin, eds., The Cultures of Creationism: Anti-Evolution in English-Speaking Countries (Burlington, VT: Ashgate Publishing Co., 2004).

${ }^{32}$ Ibid., 12.

${ }^{33}$ Ibid., 7. 
the literature of Genesis is bypassed or, as I will argue below, "screened out," by the CM in an effort to reduce complexity and to simplify causal postulates.

The second important chapter in The Cultures of Creationism is titled "The New Creationism: Its Philosophical Dimension," by Michael Ruse. ${ }^{34}$ Ruse, a philosopher, has written a number of books on creationism. The chapter identifies three of the most sophisticated and popular creationists alive in North America today. They are Phillip Johnson (Berkeley, law professor), Michael Behe (Lehigh, biochemist), and Alvin Plantinga (Notre Dame, philosopher). Johnson and Behe's sources have been sold at the CM's bookstore, however, neither author is a creationist of the young-earth variety. Rather, they follow what has come to be called Intelligent Design, a broad range of directed or planned evolution. Of interest to my project will be how the CM justifies using these books while the authors (Johnson and Behe) hold to a form of theistic evolution, a position that the $\mathrm{CM}$ adamantly rejects.

The Evolution-Creation Struggle (2005), the most significant book on creationism by Michael Ruse, surveys the debate between evolution and creation from the years preceding Darwin to the date of the book's publication. Ruse identifies two common denominators in YEC: premillenialism and catastrophism. One year later Eugenie C. Scott, Executive Director of the National Center for Science Education, produced the first edition of a thorough examination of the creation and evolution controversy. ${ }^{35}$ This book is quite broad as it deals with the proper role and place of science, as well as the development of various creationist positions. Most of her treatment deals with the more sophisticated Intelligent Design (ID) proponents, however, she chronicles YEC in a few

\footnotetext{
${ }^{34}$ Ibid., 175-92.

${ }^{35}$ Eugenie C. Scott, Evolution vs. Creationism: An Introduction, $2^{\text {nd }}$ ed. (Berkeley: University of California Press, 2006).
} 
pages. Scott mentions Ken Ham and Answers in Genesis as she narrates the major influences of YEC. She predicts "that young-Earth creationism is expanding its potential for influence toward the end of the first decade of the twenty-first century." ${ }^{36}$ This statement signals the need for further analysis of YEC to which I hope my dissertation will be a contribution.

Arthur McCalla's The Creationist Debate was also published in 2006. This book devotes an entire chapter to "Young-Earth Creationism." The contribution of McCalla's study is his identification of YEC as a fundamentalist culture. He also connects the earlier fundamentalist concern with inerrancy to the YEC movement - a major premise of my research at the CM. In 2011, Randall J. Stephens and Karl W. Giberson devoted an entire chapter to the analysis of Ken Ham and the CM. ${ }^{37}$ This chapter is especially helpful as it documents how someone like Ham, with no scientific or biblical credentials in academics, is able to become a voice of authority for many fundamentalists and evangelicals. The concept of an "anointed" spokesperson comes to be viewed by true believers as more important than academic training. This area of an authoritarian spokesperson is one that I will seek to expand on in an analysis of the CM.

In addition to Stephen's and Giberson's book, the two most extensive discussions of the $\mathrm{CM}$ are Evolution and Religion in American Education, by David E. Long (George Mason University), and Among the Creationists, by Jason Rosenhouse (James Madison University). ${ }^{38}$ Long's research is ethnographic in nature and is primarily focused on

${ }^{36} \mathrm{Ibid}, 110$.

${ }^{37}$ Randall J. Stephens and Karl W. Giberson, The Anointed: Evangelical Truth in a Secular Age (Cambridge, MA: Harvard University Press, 2011). The first chapter, "The Answer Man," is a reference to Ken Ham and Answers in Genesis.

${ }^{38}$ David. E. Long, Evolution and Religion in American Education: An Ethnography (New York: Springer, 2011) and Jason Rosenhouse, Among the Creationists: Dispatches from the Anti-Evolution Front Line (Oxford: Oxford University Press, 2012). 
issues of science education in public school settings. However, he identifies existential anxiety on the part of students who have been raised in fundamentalist and evangelical homes as a powerful factor in misunderstanding evolution. He identifies a dichotomous logic and competing epistemologies as the primary locus of this tension. Long also makes the observation that Ken Ham and Richard Dawkins have become "symbolic placeholders" to many in American society. My research will interact with and expand on Long's findings in the areas of existential anxiety and dichotomous logic.

Rosenhouse, a mathematician, provides a lengthy reflection of his more informal study of creationism over the past decade. He devotes nearly forty pages to the CM in his personal, philosophic, and mathematic analysis. An important thesis of his work is the appeal of clarity and simplicity in the CM and YEC message. My research will seek to expand on the importance of simplicity and clarity in connection with the larger dualistic schemata of God, self, and world — as proposed by Mark C. Taylor and applied through linguistic analysis of Norman Fairclough. My hypothesis is that the threefold schemataGod, self, and world — are conceptualized by CM proponents as sharply divided, dualistic categories. God is seen as transcendent and yet always present and accessible. The human self is in one of two absolute states, either redeemed (able to understand properly) or condemned (blinded and unable to understand). The $\mathrm{CM}$ also sees the world as divided in that it has been corrupted by sin and thus is unintelligible apart from divine information. ${ }^{39}$ They assert that meaning and order in this world are extrinsic and only knowable by God.

\footnotetext{
${ }^{39}$ This is the same explanation as given by Mark C. Taylor in After God (Chicago: The University of Chicago Press, 2007), 39-40.
} 
Thus, all scientific inquiry and general/natural ${ }^{40}$ revelation is tainted and must be decoded through biblical interpretation. My goal is to illustrate how the simplicity and clarity proposed by Rosenhouse is established within the dualistic schemata outlined above. Ella Bulter published an important article on the CM in Ethnos journal. ${ }^{41}$ As I have stated in my dissertation prospectus, at a most fundamental level I see the CM as the construction of an epistemological structure. If people can be led to accept the CM's either/or set of premises as to knowledge systems, then those with Christian faith only have one set of options as to how humans can know anything about the world. Butler shows how the CM uses a type of Kuhnian reasoning as it challenges the narrative of mainstream science - as if there were only one. Ironically, the CM ends up becoming surreptitiously post-modern in its approach — although they would never claim to be postmodernists.

Further, Butler shows how the CM presents the Bible (here they assume an ultimate, single and correct interpretation of the Bible that they alone have found) as the only reliable source for interpreting the natural world. Scientists, on the other hand, have agendas and biases that jade the correct interpretation of fossil and geologic data. Butler articulates how empirical data alone is not enough for the creationists. Their claim to the ultimate and inerrant status of the Bible gives them warrant to go about decoding empirical data in the correct way-i.e. the way in which the premises have been set by God as opposed to scientists looking at the same empirical data but with the missing premises. Butler writes, "Therefore, the Creation Museum is, on one level, a negotiation

\footnotetext{
${ }^{40}$ General or natural revelation in theology refers to the insights God has revealed through the creation-i.e. the physical universe. This is a problem for the CM and they resist the category of natural revelation.

${ }^{41}$ Ella Butler, "God is in the Data: Epistemologies of Knowledge at the Creation Museum," Ethnos 75:3 (September 2012): 229-51.
} 
of incommensurability, an attempt to maintain a coherent Biblical narrative that straddles competing epistemic structures." Butler's article also makes an important observation about how the CM views the Bible itself as the ultimate and supreme artifact. ${ }^{42}$ The Bible, seen as an ultimate and true artifact, trumps every other form of evidence in the YEC's mind. In fact, one hypothesis I have developed is that because the Bible is seen in this category, the need for a collection of artifacts - the normal approach to organizing a museum-is not important at the CM.

A third aspect of Butler's article that I apply is her identification of the CM's use of conspiracy theory to explain mainstream evolutionary science. The only way to explain why the scientists at the $\mathrm{CM}$ are not published in peer-reviewed science journals, since some of them have Ph.D.s from reputable schools, is to invoke a conspiracy by evolutionists against YEC. I focus on this aspect in my interviews with the science staff at the $\mathrm{CM}$.

Published in 2012, geology professor David Montgomery (University of Washington) has delivered a monograph that explains the many flaws of flood geology. ${ }^{43}$ Montgomery writes for a popular audience, however, the book does get technical at various points. Diagrams and visual illustrations help the reader who is not trained in geology. The book raises a great number of problems with Whitcomb and Morris' approach to flood geology. One important aspect of this book for my research is that it provides confirmation for some of the problems that I have seen with flood geology but

\footnotetext{
${ }^{42}$ The identification of the Bible as "artifact" in fundamentalist and evangelical culture has been made by two scholars recently: Brian Malley, How the Bible Works: An Anthropological Study of Evangelical Biblicism (Walnut Creek, CA: Alta Mira Press, 2004) and James S. Bielo ed. The Social Life of the Scriptures: Cross Cultural Perspectives on Biblicism (New Brunswick, NJ: Rutgers University Press, 2009).

${ }^{43}$ David R. Montgomery, The Rocks Don't Lie: A Geologist Investigates Noah's Flood (New York: W.W. Norton, 2012).
} 
lack the expertise to be confident about. Further, Montgomery provides a basis that informs numerous of my interview questions, especially with the staff members at the $\mathrm{CM}$, some of whom are scientists themselves.

Chapter 10, "Dinosaurs in Paradise" is a summary discussion of Montgomery's visit to the $\mathrm{CM} .{ }^{44} \mathrm{He}$ briefly touches on the problems with the geologic presentations at the $\mathrm{CM}$ such as the attempt to explain the vast geologic columns as a result of a global flood. Additionally, he notes the dichotomous attempt to place mainstream science and human reason as the conspiratorial culprits of modern social problems. This chapter is valuable because it is a credentialed geologist's analysis of the fallacious and inaccurate presentations at the CM. Some of these mistakes I have posited myself, however, it is quite valuable to have a scientific expert comment on the specific exhibits that I will be analyzing. The book is important because it addresses the largest section of floor space in the CM's main exhibits-flood geology. ${ }^{45}$

\section{Evangelical Literature on Creationism}

The second group of scholars who have written about YEC and the CM have been evangelicals themselves. While "evangelical" includes a wide range of positions, the scholars to which I refer all have the shared commitment to evolution as the mechanism of creation. The most substantial work dealing with YEC to date is Denis O. Lamoureux's (University of Alberta, professor of science and religion) Evolutionary Creation. Lamoureux has contributed significantly to my thinking about YEC, especially as he has identified concordism and phenomenological aspects of YEC as two imperative

\footnotetext{
${ }^{44}$ Ibid., 179-99.

${ }^{45}$ See Appendix-“A Narrative Overview of the Creation Museum," 16-18.
} 
pieces of the debate over origins. Lamoureux's book was published one year after the CM opened. The book does not deal with the CM as it focuses on YEC more broadly. Gordon J. Glover has also written a more popular critique of YEC, which interacts briefly with Lamoureux's points. ${ }^{46}$ Glover's book lacks the depth of Lamoureux's, but it is far easier to read and Glover also comes from an evangelical position.

Francis S. Collins, Karl W. Giberson, and Kenneth R. Miller are scientists who have written a number of important critiques of creationism. ${ }^{47}$ Miller (Brown University, biology) is Catholic and Giberson (Eastern Nazarene College, physics) and Collins (Director, National Institutes of Health, genetics) are Protestant Evangelicals, but they are all widely published research scientists. The books listed in the footnote below amount to over one-thousand pages of the scientific responses to the fallacies of both YEC and Intelligent Design. They are written for popular audiences, however, they can be quite technical at times - especially Miller's books. In my dissertation, I will draw from some of the insights in these sources as they relate to public presentations of scientific information.

In 1988, three evangelical scientists (Howard J. Van Till, Davis A. Young, and Clarence Menninga) from Calvin College wrote an important book on the problems on both extremes of the evolution/creation debate. That book, Science Held Hostage: What's Wrong with Creation Science AND Evolutionism, is basically an evangelical equivalent to

\footnotetext{
${ }^{46}$ Gordon J. Glover, Beyond the Firmament: Understanding Science and the Theology of Creation (Chesapeake, VA: Watertree Press, 2008).

${ }^{47}$ Kenneth R. Miller, Finding Darwin's God: A Scientist's Search for Common Ground Between God and Evolution (New York: Harper Perennial, 1999) and Only a Theory: Evolution and the Battle for America's Soul (New York: Viking, 2008); Karl W. Giberson, Saving Darwin: How to be a Christian and Believe in Evolution (New York: Harper One, 2008); and Karl W. Giberson and Francis S. Collins, The Language of Science and Faith (Downers Grove: IL, 2011).
} 
Stephen Jay Gould's call for non-overlapping magesteria. ${ }^{48}$ An important point of caution is set forth in which the authors explain the limits of empirical science on the one hand and theology and philosophy on the other. The methodologies of these domains are different as they seek to investigate separate realms of knowledge. Science Held Hostage is as critical of scientists who draw conclusions about the nature of God as it is of creation science's attempt to substitute Biblicism as science. The book also contains a helpful epilogue that identifies creation science as "folk science." While the book is now quite dated, it was the first organized effort to answer numerous fallacious arguments put forth by YEC. However, it is neither as extensive nor up-to-date a critique in answering hundreds of YEC arguments as that found in Mark Isaak's book, The Counter-Creation Handbook ${ }^{49}$ Three other strengths of Science Held Hostage are that it was one of the few books written by Christians who are also credentialed scientists, it scientifically answers the fallacious arguments set forth by YECs, and is written for a popular audience.

In 2012, Gerald Rau published Mapping the Origins Debate: Six Models of the Beginning of Everything. ${ }^{50}$ The book has several strengths. First, it is accessible for educated people who are not specialists in biblical studies or evolutionary science. The subtitle sets out the basic structure of the book-i.e. that there are six basic viewpoints on origins. Those six are: naturalistic evolution, non-teleological evolution, planned evolution, directed evolution, old-earth creationism, and young-earth creationism. Having this spectrum organized and clarified is quite helpful for people who are not familiar with

\footnotetext{
${ }^{48}$ Howard J. Van Till, Davis A. Young and Clarence Menninga. Science Held Hostage: What's Wrong with Creation Science and Evolutionism (Downers Grove, IL: InterVarsity Press, 1988). Gould's article, "Non-overlapping magesteria," is cited in footnote 5.

${ }^{49}$ Mark Isaak, The Counter-Creation Handbook (Berkeley: University of California Press, 2007).

${ }^{50}$ Gerald Rau, Mapping the Origins Debate: Six Models of the Beginning of Everything (Downers Grove, IL: IVP Academic, 2012).
} 
the range of creationist and evolutionist positions. Second, the book avoids drawing rigid and dogmatic lines between evolution and creationism. On this note, the book is mostly descriptive of all the varying positions without taking sides. Third, Rau's categories are complete. In all of my research, I have not run across any position, atheistic or creationist, which falls outside of Rau's map. Fourth, the book contains a helpful set of charts to show how the various positions line up with respect to basic propositions, theologies, scientific methodologies, and underlying philosophies involved in the various positions.

Two sources from evangelical biblical scholars also address the textual and interpretive problems of creationism. ${ }^{51}$ These are valuable sources that serve to answer numerous theological, historic, and interpretive problems with the way the CM and YEC uses biblical texts. Citations from these books will aid in giving evangelical responses to issues that are never mentioned at the CM. Additionally, Christopher Southgate has written a book devoted to answering the theological problems involved in evolution and aspects of moral and physical evil—many of these problems are ones that the CM uses as premises for the YEC position. ${ }^{52}$ Benedictine priest and theologian Stanley L. Jaki's history of interpretation, Genesis One Through the Ages, presents the historic problems of concordist interpretations throughout Christian and Jewish history. ${ }^{53}$ Jaki's book and

${ }^{51}$ Peter Enns, The Evolution of Adam: What the Bible Does and Doesn't Say About Origins (Grand Rapids: Brazos Press, 2012) and John H. Walton, The Lost World of Genesis One: Ancient Cosmology and the Origins Debate (Downers Grove, IL: Intervarsity Press, 2009).

52 Christopher Southgate, The Groaning of Creation: God, Evolution, and the Problem of Evil (Louisville: Westminster John Knox Press, 2008).

${ }^{53}$ Stanley L. Jaki, Genesis 1 Through the Ages (Edinburgh: Scottish Academic Press, 1998). 
selections from the edited work, The Book of Nature in Early Modern and Modern History, provide illustrations of how certain information is screened at the CM. ${ }^{54}$

Genesis and Christian Theology is a recent book with essays by twenty-one biblical scholars and systematic theologians. ${ }^{55}$ David Fergusson's essay, "Interpreting the Story of Creation," provides historical and theological perspective to how Genesis has been handled throughout the past two millennia. ${ }^{56}$ It is shorter than Jaki's history of interpretation but it is more up to date. It demonstrates some of the historical tensions in the ongoing dialogue between theology and science. Fergusson makes clear that after the rise of modern biblical criticism in the late $19^{\text {th }}$ century, the vast majority of biblical scholars and theologians have come to reject that theology has any place in science texts. However, this is exactly what the CM would argue is imperative for any proper interpretation of the Bible.

\section{Critical Biblical Scholarship on Genesis}

The third category of literature, critical biblical commentaries, also plays an important part in my research. Because there are hundreds of commentaries on Genesis alone, I will refer to three or four well-respected volumes to briefly explain the consensus approach of exegetes on the early chapters of Genesis. Additionally, I will limit these sources to only critical commentaries by peer reviewed publishers. One of the most respected and enduring commentaries on Genesis was written by Gerhard Von Rad. ${ }^{57}$

\footnotetext{
${ }^{54}$ Klaas Van Berkel and Arjo Vanderjagt, eds., The Book of Nature in Early Modern and Modern History (Leuven, Belgium: Peeters, 2006).

55 Nathan MacDonald, Mark W. Elliott, and Grant Macaskill, eds., Genesis and Christian Theology (Grand Rapids, MI: William B. Eerdman's Publishing, 2012).

${ }^{56}$ Ibid., 155-74.

${ }^{57}$ Gerhard Von Rad, Genesis, Rev. ed. (Philadelphia: The Westminster Press, 1971).
} 
Von Rad and the other scholars I cite hold to some variation of the documentary

hypothesis - that the Torah was edited and expanded over hundreds of years by Priestly (P), Jahwistic (J), Deuteronomistic (D), and Elohistic (E) writers. Thus, I judge Genesis 1:1-2:4 $a$ to be of a later date than Genesis 2:4b-25 and that Genesis 1 was added by a Priestly writer or writers. ${ }^{58}$ Based on the work of biblical scholars (Fretheim, Von Rad, Jaki, Westerman, and Arnold), I agree that the time frame of the Genesis 1 composition is from the post-exilic period (i.e. after the Babylonian exile—Sixth century BCE or later). Thus seen, Genesis 1 was part of a Priestly effort at restructuring Jewish identity after exile. Sabbath observance was at the center of this identity and would fit nicely with the creational order in the six days of God's work and rest on the seventh. The best category for the genre of Genesis 1:1-2:4a is what Stanley Jaki has called a "didactic recital. ${ }^{, 59}$ In my introductory classes of the Hebrew Scriptures, I adapted Jaki's phrase to identify the genre of Genesis 1 as a "liturgical poem." ${ }^{60}$ It is essentially an effort to reestablish the Sabbath rhythms of life after having lost much Jewish identity whilst in Babylon.

As for interpretation of Genesis 1, there is some variance among biblical scholars. The overwhelming majority of peer reviewed commentaries interpret Genesis 1 as an ancient Near Eastern (ANE) convention that tells the story of creation out of the chaotic primordial waters—a feature common in related ANE creation stories. ${ }^{61}$ Enuma Elish, a Mesopotamian creation myth, came from a much earlier and well-established culture and

\footnotetext{
${ }^{58}$ Genesis 2:4b-25 is seen to be composed by a Yahwist writer at an earlier period than the Priestly writer/s.

${ }^{59}$ Stanley L. Jaki, Genesis 1 Through the Age, 2nd ed. (Edinburgh: Scottish Academic Press, 1998), 288.

${ }^{60}$ Walter Brueggemann identifies the form of Genesis 1 as "liturgical." An Introduction to the Old Testament: The Canon and Christian Imagination (Louisville: Westminster John Knox Press, 2003), 29.

${ }^{61}$ The two most common ANE creation stories are found in Enuma Elish (Heidel) and the Gilgamesh Epic (Gardner and Maier). These epics contain strikingly similar accounts as that found in Genesis. Scholars have also noted important differences. (See Kenton Sparks, Ancient Texts for the Study of the Hebrew Bible (Peabody, MA: Hendrickson Publishers, 2005).
} 
is a likely source that informed the Hebrew imagination concerning creation-the main difference being the Hebrew, monotheistic perspective to the Mesopotamian, polytheistic perspective. Usually categorized as "myth," these creation stories were aetiological in that they sought to provide causes for the existence of world and for its machinations. For the Hebrew people, Genesis 1 served as the true, monotheistic version of creation myth to be set apart from other competing cosmologies in the ANE. Since the Genesis 2 account of creation presents a different order of created things- e.g. man is created before the plants—and because it is a much older account (Jahwist), it is unlikely that the ancient writers were overly concerned with the material processes involved in creation. Rather, they told these creation accounts with certain functional goals in mind. In the account of Genesis 1, I offer the following as examples of such functions: an explanation of one God as creator; a description of order over chaos; the setting forth of a work-week and Sabbath; and the establishment of what has come to be known as God's sovereignty over the creation. The majority of critical commentaries would agree to most or all of these purposes of Genesis 1.

John Walton provides a most helpful connection between Genesis 1 and the ANE practice of temple inauguration. ${ }^{62} \mathrm{He}$ demonstrates that ancient Mesopotamian practice, like that of the Hebrews, held that the actual creation of a temple occurred at the inauguration ceremony — not at the actual building of the temple structure itself. This is a feature of the ANE that is not transparent to modern readers. Walton uses the example of Solomon's Temple to illustrate such an inauguration. 1 Kings 8 describes a seven-day feast and banquet at the consecration/establishment of Solomon's Temple. A parallel can

\footnotetext{
${ }^{62}$ John H. Walton, The Lost World of Genesis One: Ancient Cosmology and the Origins Debate (Downers Grove, IL: Inter Varsity Press, 2009).
} 
be found as well in Enuma Elish, with the god Marduk ascending as the head of the gods as he built and created the temple.

Walton's thesis makes much more sense of Genesis 1 as the telling of God's inauguration of a cosmic temple which, in the minds of those in the ANE, implies the taking control of all lesser functionaries down to planet earth. In his words, "In this way of thinking, Genesis 1 would be a recounting of the functional origins of the cosmos as a temple that was rehearsed yearly to celebrate God's creation and enthronement in the temple. ${ }^{63}$ Such a reading of Genesis 1 also compliments the understanding of the genre as a liturgical poem. As Moshe Weinfeld has observed, Genesis 1 could have served as liturgy for such an inaugural celebration. ${ }^{64}$ This reading would make perfect sense given the impetus among the Priestly push to rebuild Solomon's Temple after the exile and to reassert Jewish Sabbath custom. Finally, this would also explain why the Priestly source writers had no problem giving an account that differed from the Jahwist in Genesis 2.

In addition to monographs and journal articles on creationism discussed above, there are hundreds of articles and papers written and published by the following organizations which will be used when relevant in the dissertation. These sources are The American Scientific Affiliation, Biologos Foundation, and the National Center for Science Education. These organizations have provided a tremendous amount of scientific and biblical data addressing YEC and the CM.

${ }^{63}$ Ibid., 91.

${ }^{64}$ Moshe Weinfeld, "Sabbath, Temple and the Enthronement of the Lord-The Problem of the Stitz im Leben of Genesis 1.1-2.3," in Mélanges bibliques et orientaux en l'honneur de M. Henri Cazelles, ed. A. Caquot and M. Delcor, Alter Orient und Altes Testament 212 (Neukirchener-Vluyn: Neukirchener; Kevelaer: Butzon \& Bercker, 1981), 502-12. 


\section{Conclusion}

While the relevance of these three categories of literature for my research will become clearer as I apply them to the analyses in the dissertation, I will provide a brief summary of how this literature connects with my research at the CM. The work by scholars on YEC provides a historical narrative which helps to inform my questions concerning the influences of this newer generation of creationists. ${ }^{65}$ For example, the Seventh-Day Adventist origin of YEC and catastrophism, as documented by Numbers, provided a number of questions for my interview with John C. Whitcomb. An historical overview of the last seventy years of YEC also allows me to see what aspects of the movement have remained constant and which ones have fallen away. Even within YEC, the CM presents its own, highly selective version of creationism as the definitive position.

Toumey’s works are especially important as he defines the ways in which YECs have used the term "secular humanism" as a pejorative label that has come to be equated with all that fundamentalists feel is wrong with modern society. ${ }^{66}$ Ken Ham employs this term constantly as he links secular humanism with evolution, atheism, academia, and a list of other terms that stand as culprits of societal decadence and immorality. In analyzing the argumentation at the CM, I will draw from Toumey's work in illustrating the concept that has been constructed for secular humanism in the minds of CM proponents.

\footnotetext{
${ }^{65}$ The list of scholars, cited above, are: Numbers, Toumey, Coleman, Ruse, Scott, and McCalla.

${ }^{66}$ In addition to God's Own Scientists, cited above, Toumey also has a fuller discussion of the misuse of "secular humanism" by fundamentalists in Conjuring Science: Scientific Symbols and Cultural Meanings in American Life (New Brunswick, NJ: Rutgers University Press, 1996).
} 
Coleman and Carlin provide a helpful framework as I attempt to explain how the $\mathrm{CM}$ offers the typically fundamentalist effort to restore the world to a more certain moral authority. Ruse, Scott, Montgomery, and McCalla all help to form many of my ethnographic interviews as they provide scientific aspects of YEC that are outside of my field. These are especially helpful in interviewing the scientists on staff at the CM. Long's ethnographic work contributes to my analysis of the symbiotic relationship that I see between extremists like Ham and Dawkins. Each person has become a symbolic placeholder of a particular variety of extremism which is ironically helpful as each side can point to the other as an example of what happens when one believes "the other postion"-neglecting to note that the vast majority of positions are actually somewhere in between the extremes.

Butler offers two important observations about the CM directly. First, she discusses the framework of competing epistemologies - this is one of the most prevalent forms of discourse at the CM. Second, like Malley and Bielo, she identifies how the CM has come to view the Bible as the ultimate artifact. This aspect has textual, verbal, and visual dynamics that I intend to analyze at the CM far beyond the scope of Butler's article.

Lamoureux has provided the fullest discussion of concordism among creationists. I will attempt to show how the concordist interpretation of Genesis forces the CM to distance itself from mainstream biblical scholarship and science. This is one form of "screening" information that occurs at the CM. The work of Van Till, Young, and Menninga establishes the pseudo-scientific approaches of the CM as "folk science." 
While the book predates the opening of the CM, my goal is to explain how the form of science presented at the CM could be classified as folk science.

In the last category of critical biblical scholarship, I will use the insights of various scholars to show how certain parts of Genesis 1 have been totally avoided by the CM. Certain ANE viewpoints present a radically different phenomenological world. We find clues to this different cosmology within the biblical texts, especially Genesis. In the bookstore as well as in audio, video, and museum displays, no mention of alternative interpretations is even discussed. For example, I intend to document how the concept of an ancient firmament holding up a heavenly sea — while present in Genesis1—is avoided and also reinterpreted. This is one more way that information is screened at the CM.

In the later chapters of the thesis, I will show more connections between the literature I have reviewed and other aspects for analysis at the CM. The particular questions in the ethnographic interviews have been informed largely from an overall picture that has arisen in my reading of these sources. Further, the primary sources for my dissertation — publications at the $\mathrm{CM}$-also interact at various points with some of the sources I have discussed. I will address these connections as they arise in the course of my analysis. 


\section{CHAPTER II}

\section{THEORIES PERTAINING TO AN ANALYSIS OF THE CREATION MUSEUM}

Analyzing the Creation Museum (CM) requires several methodological approaches. These different methods are required because the CM espouses an interpretation of Genesis 1, uses multi-media dialogue to present this interpretation, and also attempts to undermine evolutionary science. This chapter addresses aspects of HansGeorg Gadamer's hermeneutic theory to demonstrate the interpretive procedures used at the CM. Following this section, I will use written sources from Ken Ham as an example of a literalist approach to interpretation based on Vincent Crapanzano's definition of "literalism."

The CM's wider message involves a merging of selective, literalist biblical interpretations with selective aspects of the modern world. The CM conflates these two selective aspects which results in the suggested causes and solutions for evil in the world today. Here I will apply two concepts from Norman Fairclough's theory of Critical Language Study (CLS) to show how this coherent worldview is portrayed and maintained at the CM.

I define the CM as a Complex Adaptive Network (CAN) based on Mark C. Taylor's definition of religious culture. ${ }^{67}$ Additionally, I will explain how I intend to apply the process of "screening information" to the CM. Taylor's theory will be applied

\footnotetext{
${ }^{67}$ Mark C. Taylor, After God (Chicago: The University Press of Chicago, 2007), 12.
} 
mostly to the CM's criticisms of evolutionary science. The concluding chapter of the dissertation will include how network society and rapid increases of information may contribute to a larger societal anxiety which provide fertile ground for fundamentalism.

\section{$\underline{\text { Hermeneutics }}$}

\section{Gadamer's Horizon and Closed Approaches to Interpretation}

A hermeneutical analysis is of central importance in analyzing the CM because the museum espouses not just an interpretation of certain biblical texts, but also that a young earth creationist (YEC) interpretation of the Bible is the one and only correct interpretation. My analysis will consist of the following sections. First, I will define hermeneutics as it will be used in this dissertation. Second, I will draw from several insights of Hans-Georg Gadamer (1900-2002) in establishing two approaches to hermeneutics. These insights include Gadamer's "fusion of horizons," the idea of translation as interpretation, and the importance of asking questions as a crucial hermeneutic posture. Further, I will explain that the two approaches mentioned above may be conceptualized as "open" versus "closed" interpretive endeavors. Third, I will frame the CM's approach to interpretation as "closed." This will enable me to address publications, placards, lectures, media presentations, and imagery with the basic hermeneutic framework established below.

Hermeneutics has been variously defined in publications ranging from methods for the interpretation of biblical texts to the philosophy of language. Hermeneutics is defined in Webster's dictionary as "the art or science of the interpretation of literature." 68 I would argue that hermeneutics is both the art and science of interpretation. As an art,

\footnotetext{
${ }^{68}$ Webster's New World Dictionary, $3{ }^{\text {rd }}$ College ed., s.v. "Hermeneutics"
} 
hermeneutics requires sensitivity to literature, poetry, culture, and visual imagery. As a science, hermeneutics requires rigorous critical tools for the analysis of literary textsincluding lexicons, grammars, textual commentaries and translations, and a variety of other critical tools. Additionally, hermeneutics is descriptive of a process of interpretation. As such, hermeneutics may be described as a "phenomenology of understanding." 69

One of Gadamer's important contributions to this field lies in his insistence on hermeneutics as an ever increasing process of understanding. He articulates hermeneutics in a couple of ways. First, "The principle of hermeneutics simply means that we should try to understand everything that can be understood." ${ }^{, 70}$ The implication here is that there is more to understanding than just the words on a page. What the reader brings to the text, including her cosmology, theology, philosophy, etc., all contribute to the way the reader interprets the words on the page. Second, "Understanding is to be thought of less as a subjective act than as participating in an event of tradition, a process of transmission in which past and present are constantly mediated." "71 Following Gadamer, I define hermeneutics as a dynamic process that seeks to understand a text and is always open to revision when given new insights from the author's or interpreter's horizon. This will be developed throughout my analysis as opposed to interpretation based on a dogmatic presupposition which is closed to further questioning.

${ }^{69}$ Richard N. Soulen, Handbook of Biblical Criticism, ${ }^{\text {nd }}$ ed. (Atlanta: John Knox Press, 1981), 82. Gadamer brought hermeneutics into the area of phenomenology following the influences of his influential teacher, Martin Heidegger. Heidegger was previously influenced by Edmund Husserl. "Philosophical hermeneutics" became an interdisciplinary field which drew attention from linguistics, anthropology, semiotics, pragmatics, and sociology.

${ }^{70}$ Hans-Georg Gadamer, Philosophical Hermeneutics, trans. David E. Linge (1976; repr. Berkeley: University of California Press, 2008), 31.

${ }^{71}$ Hans-Georg Gadamer, Truth and Method, trans. and ed. Joel Weinsheimer and Donald G. Marshall, $2^{\text {nd }}$ rev. ed. (1989; repr., New York: Continuum, 2006) 291. 
In Truth and Method, Gadamer explains one of Heidegger's terms- - "for-

structure" or the process of projecting meaning onto things - and its implications for the interpretive process.

A person who is trying to understand a text is always projecting. He projects a meaning for the text as a whole as soon as some initial meaning emerges in the text. Again, the initial meaning emerges only because he is reading the text with particular expectations in regard to a certain meaning. Working out this foreprojection, which is constantly revised in terms of what emerges as he penetrates into the meaning, is understanding what is there. ${ }^{72}$

Having an awareness of such a projection is crucial for the interpretive process. In fact, I would argue that the better one becomes at recognizing one's own projections, as well as the projections of others in the history of interpretation, the more attentive that individual will become to all texts. The result is a better interpretive sensitivity. I have observed a similar lack of sensitivity to one's own projections in fundamentalist interpretation, especially when it comes to aspects of a text which are counterintuitive. ${ }^{73}$

Part of such a projection is the prejudice of the interpreter. These prejudices (Vorurteile) contribute to one's projection of a certain interpretive horizon onto a text to the potential neglect of an ancient writer's projection. Gadamer brings attention to these so called "two horizons." Borrowing the term from Husserl, the horizon is defined by Gadamer as "the range of vision that includes everything that can be seen from a particular vantage point." "74 Of course, he uses the word "sight" in a metaphorical sense, meaning comprehension of the realm of one's context. In addition to one's own horizon, the second involves the contextual realm of the text under scrutiny (e.g. the ancient Near

${ }^{72}$ Gadamer, Truth and Method, 269.

${ }^{73}$ For example, one counterintuitive mistake is the reading into an ancient text, a modern notion. This mistake has also been called eisegesis as opposed to exegesis. An easy example is the common assumption that biblical writers understood a helio-centric or geo-centric view of the universe when they actually held to an ancient, three-tiered cosmology. Both horizons, the ancient and the modern, need to be carefully assessed in order to avoid the projection of one horizon to the detriment of the other.

${ }^{74}$ Gadamer, Truth and Method, 301. 
Eastern horizon in the case of interpreting the Old Testament). He adds that "working out the hermeneutical situation means acquiring the right horizon of inquiry for the questions evoked by the encounter with tradition." ${ }^{, 75}$ So as the interpreter sees one's own present horizon merge with the historical horizon of the text, a "fusion of horizons" takes place and this fusion yields understanding. ${ }^{76}$

In fundamentalist circles, interpretation tends to be limited by a one-sided projection. ${ }^{77}$ In the case of the $\mathrm{CM}$, the most significant hermeneutical error occurs in the projection of a modern understanding of cosmology onto Genesis. This will be the primary area of analysis of Chapter IV. But here it serves to illustrate why Gadamer's theory of hermeneutics is so relevant to my analysis. Gadamer described exactly what may happen when someone neglects one horizon to the detriment of the other. "The hermeneutic task consists in not covering up this tension by attempting a naïve assimilation of the two [horizons] but in consciously bringing it out." ${ }^{.78}$ I will demonstrate how the CM covers-up the ancient horizon with a modern one.

One of the most significant projections of fundamentalists are the doctrines of inerrancy and infallibility. Biblical exegetes who take care to consult critical studies have overwhelmingly distanced themselves from these doctrines. If they have not rejected inerrancy outright, then they have defined it in terms relating to faith and practice rather than science and history. Thus, it is no surprise that in the few cases where biblical criticism is mentioned at the $\mathrm{CM}$, it appears only as the subject of critique and is the

\footnotetext{
${ }^{75}$ Ibid., 302.

${ }^{76}$ Ibid., 306.

${ }^{77}$ Anthony Thiselton notes this tendency which he describes as only focusing on the "second" horizon - i.e. the interpreter's horizon. Anthony C. Thiselton, Hermeneutics (Grand Rapids, MI: Eerdmans, 2009), 3.

${ }^{78}$ Gadamer, Truth and Method, 305.
} 
result of sinful approaches to studying the Bible. The study of ancient Near Eastern literature opens a horizon that calls into question and exposes modern cosmological horizons for what they are-recent conceptualizations that have no historical evidence as ever having been present in the minds of ancient Near Easterners. ${ }^{79}$

One example of such a projection is found in the biblical commentaries of reformer John Calvin (1509-1564). In 1543, the geocentric model of the universe met its first great challenge when Nicolaus Copernicus (1473-1543) published On the Revolutions of the Heavenly Spheres. The Ptolemaic or geocentric model had been in place for nearly thirteen-hundred years at the time of Copernicus' treatise. Further, the Ptolemaic model would not be overturned until years after Galileo Galilei (1564-1642) wrote his Dialogue Concerning the Two Chief World Systems (1632). Opinion about the validity of the heliocentric model of Copernicus and Galileo was slow to come. For Calvin and Martin Luther (1483-1546), the heliocentric model was heresy because it contradicted their traditional interpretations of certain biblical passages.

Psalm 93:1 declares, "He [God] has established the world; it shall never be moved." ${ }^{\prime 80}$ The majority of Catholic and Protestant theologians rejected the heliocentric model until well into the eighteenth-century. Calvin was caught between two interpretive horizons. The older three-tiered cosmology of the Ancient Near East was not even discussed by Calvin. So the obvious option for Calvin was the geocentric model, which seemed to confirm a few basic texts like Psalm 93. Calvin's interpretive horizon when reading the passage quoted above led him to the following interpretation:

\footnotetext{
${ }^{79}$ I make this bold claim based on extensive comparisons between the text of Genesis 1 and Mesopotamian and Egyptian epigraphy. These comparisons will be developed at length in Chapter IV.

${ }^{80}$ New Revised Standard Version.
} 
The heavens revolve daily, and, immense as is their fabric, and inconceivable the rapidity of their revolutions, we experience no concussion-no disturbance in the harmony of their motion. The sun, though varying its course every diurnal revolution, returns annually to the same spot. The planets, in all their wanderings, maintain their respective positions. How could the earth hang suspended in the air were it not upheld by God's hand? By what means could it maintain itself unmoved, while the heavens above are in constant rapid motion, did not its Divine Maker fix and establish it? ${ }^{81}$

Had Calvin been aware of an even older cosmology, held in the times of the Hebrew writers, he might have sought a less literal interpretation of this verse. He might also have listened a bit more carefully to Copernicus's argument. Rather, his projection onto the text was a rigid commitment to geo-centrism which left him with a closed set of options as to what the text might mean. This was the same projection made by the Catholic theologians who condemned Galileo to house arrest. Calvin's interpretive process concerning any text related to the cosmos demanded geo-centrism. Thus, for any such specific text Calvin brought a limited horizon to bear in extracting the meaning. These texts had to be read as geo-centric or else the very words of God were wrong. Thus, the interpretive process was closed as it allowed for geocentric interpretations.

Calvin's interpretation is an example of what modern theologians have called “concordism." 82 Denis Lamoureux defines concordism as "a method of biblical interpretation that seeks to find a correspondence between science and Scripture." ${ }^{83}$ Here is just one more description of what Gadamer would call a projection as the interpreter "is reading the text with particular expectations in regard to a certain meaning." ${ }^{84}$ In this case, the particular expectations happen to be the assumption that the Bible is written in

\footnotetext{
${ }^{81}$ John Calvin, Commentary on the Book of Psalms, vol. 6, trans. James Anderson (repr., Grand Rapids, MI: Baker Book House, 1996), 7.

${ }^{82}$ Lamoureaux conducts the most thorough discussion of concordism in biblical studies. Denis O. Lamoureux, Evolutionary Creation: A Christian Approach to Evolution (Eugene, Oregon: Wipf and Stock Publishers, 2007).

${ }^{83}$ Ibid., 14.

${ }^{84}$ Gadamer, Truth and Method, 269.
} 
terms of exactly what modern scientific observations have rendered. For Calvin, that was geo-centrism. As I will develop later, the projection for Ham is helio-centrism. But both Calvin and Ham project a culturally current cosmological paradigm onto the ancient text. Here is where one inescapable postulate of hermeneutics arises. That postulate is that a text cannot have meant something to the original author/audience that the author/audience was unable to comprehend. While it is extremely difficult to prove what an ancient writer was or was not aware of without direct interrogation, I find the postulate above to be logically necessary to at least clear the field of impossible meanings before proposing the possible meanings. With this in mind, one should remember that what we know as modern science arose during the Scientific Revolution and we find no trace of evidence that the ancient Hebrew people ever conceptualized the cosmos in anything like the Copernican sense, much less the Ptolemaic one. So to force such a cosmological notion onto any Hebrew prophet, from Moses to the Second Temple period, would be an egregious hermeneutical mistake.

This example of concordism amounts to a closed hermeneutic approach. In the minds of the interpreters (Calvin and Ham), the Bible is elevated to a level of truth that trumps all other forms of investigation, especially certain fields of scientific investigation. Ptolemaic cosmology was the dominant view for the majority of medieval Catholic and Protestant theologians. ${ }^{85}$ However, after the Scientific Revolution and the advent of modern critical studies, such approaches to Bible interpretation seem naïve, to

${ }^{85}$ The field of biblical scholarship called "history of interpretation" illustrates these trends. Three such works are: Stanley L. Jaki, Genesis One Through the Ages $2^{\text {nd }}$ rev. ed. (Edinburgh: Scottish Academic Press, 1998); Alan J. Hauser and Duane F. Watson, eds. A History of Biblical Interpretation: The Ancient Period, Vol. 1 (Grand Rapids, MI: Eerdmans, 2003); and Alan J. Hauser and Duane F. Watson, eds. A History of Biblical Interpretation: The Medieval through the Reformation Periods, Vol. 2 (Grand Rapids, MI: Eerdmans, 2009). 
say the least. This naiveté still exists in fundamentalist circles today. My analysis of the $\mathrm{CM}$ will seek to demonstrate how this type of projection - the modern onto the ancientstill occurs.

At the same time, an interpretive misfire also works in an opposite direction. A closed interpretive framework not only forces rigid anachronisms on the ancient texts, but the text — when interpreted as an authoritative epistemological source for all realms of knowledge (especially science) — causes a similarly closed approach with respect to science. Thus, the CM ends up having to purport a version of science that is mostly Enlightenment and sometimes pre-Enlightenment science. ${ }^{86}$ Since the age of the earth is assumed to be no older than six-thousand years, the CM must reject any scientific discoveries that would challenge a young earth interpretation. ${ }^{87}$ So a similar type of closure happens with any scientific theory that interferes with a young earth view of history.

Science, as it is portrayed at the CM, is also a closed endeavor. ${ }^{88}$ One of my hypotheses is that the two most neglected aspects of study at the CM are scholarly biblical exegesis and interaction with the best scholarship on evolutionary science (especially biology, astronomy, and geology). ${ }^{89}$ However, if the Bible and science are as closed and absolute as the CM maintains, then such neglect is completely understandable.

${ }^{86}$ See, Toumey, God's Own Scientists, 15-17.

${ }^{87}$ The CM has been vehement in arguing for a young earth because such a short span of time undercuts the vast ages necessary for evolution. If that one premise is accepted, then they really do not even need to deal with refuting evolutionary science because, in their minds, it could never have happened in 6,000 years.

${ }^{88}$ I find it extremely ironic that the $\mathrm{CM}$ views science as rigidly closed and limited because true scientific endeavor is always open to further refinement and testing. For science to make progress, new challenges are constantly brought to bear in efforts to test, refine, and move knowledge forward.

${ }^{89}$ In part, this lack of scholarly material also occurs because the CM is targeting a popular, layoriented audience. However, even reputable popular-lay materials on biblical interpretation and science are lacking. 
Additionally, the withholding of some positions are necessary because they offer too much counter evidence that may cause some individuals to doubt the very premises of the CM.

Another important aspect of Gadamer's analysis is the observation that all translation is an act of interpretation. In Part Three of Truth and Method, Gadamer emphasizes "Language as the Medium of Hermeneutic Experience." ${ }^{90}$ He discusses how meaning is mediated through language. In one observation he states the following: "Thus every translation is at the same time an interpretation. We can say that the translation is the culmination of the interpretation that the translator has made of the words given him." ${ }^{, 91}$ For those who have translated texts from a language other than one's native tongue, this observation seems almost obvious. However, Ham and the staff at the CM seem to be completely unaware of this important hermeneutic point.

In a talk given to YECs, Ham illustrates this lack of awareness as he addresses the crowd. "You see, people say 'You have a particular interpretation.' I don’t think so. I think I just read it. And what it says is what it means. Other people interpret it and they get into trouble., ${ }^{92}$ Ham's comments demonstrate a lack of understanding in at least two fundamental ways. First, he asserts that reading a text is somehow different from interpreting a text. Second, he seems to be unaware of Gadamer's point that any translation of the Bible into English is itself an interpretation. Ham may not be aware of this fact because he has never been trained in any of the biblical languages-Hebrew, Greek, or Aramaic.

\footnotetext{
${ }^{90}$ Gadamer, Truth and Method, 385-484.

${ }^{91}$ Ibid., 386.

${ }^{92}$ This quote is transcribed from a clip in a PBS documentary titled "Evolution." PBS, “Evolution,” Public Broadcasting Network, http://www.pbs.org/wgbh/evolution/library/08/1/1_081_04.html
} 
But anyone who has translated a biblical text should understand Gadamer's point. In fact interpretation from a translation actually becomes a twofold challenge because one is dealing with essentially two texts, that of the original language and that of the vernacular language. Gadamer addresses this point: "Having to depend on an interpreter's translation is an extreme case that doubles the hermeneutical process, namely the conversation between the interpreter and the other, and a second between the interpreter and oneself. ${ }^{" 93}$ My intention is to question Mr. Ham on some of these subtle points in the ethnographic interview. However, my preliminary hypothesis is that he is unaware of these subtle aspects of interpretation.

The fact that CM advocates are either unaware of these subtleties or deny them outright may help to explain why the perspectives of two horizons are so crucial to the hermeneutic process. I intend to demonstrate several cases where one word or phrase mistranslated can cause massive interpretive reconstructions that are anachronistic.

My view of "open" versus "closed" hermeneutics is most thoroughly explored by Gadamer in his discussion of "The Hermeneutic Priority of the Question." ${ }^{.94}$ He writes: "We will now examine the logical structure of openness that characterizes hermeneutical consciousness, recalling the importance of the concept of the question to our analysis of the hermeneutical situation." ${ }^{95} \mathrm{He}$ explains that the interpretive endeavor may be essentially structured as a question. This is a profound and crucial part of all interpretation. When someone reads, the process of questioning is always unfolding. Questioning the material is an almost unnoticeable aspect of reading. As Gadamer puts it, "In order to be able to ask, one must want to know, and that means knowing that one does

\footnotetext{
${ }^{93}$ Gadamer, Truth and Method, 387.

${ }^{94}$ Ibid., 356-71.

${ }^{95}$ Ibid., 356.
} 
not know ... The openness of what is in question consists in the fact that the answer is not settled."96

According to Gadamer, the retaining of false presuppositions causes the interpreter to ask questions from the wrong interpretive horizon. Thus, the openness of proper questions is lost and the interpretive process fails. This is the best description of the hermeneutical mistake I have witnessed in the interpretation of Genesis at the CM. The imposition of the Copernican horizon (one that closes off other interpretations) onto the text has given rise to questions about meaning that are imposed or projected on the ancient text. Similarly, the CM's concept of biblical inerrancy also forces a closed presupposition on the text. This results in exactly what Gadamer describes: "Thus, despite his scientific method, he behaves just like everyone else-as a child of his time who is unquestioningly dominated by the concepts and prejudices of his own age."97

\section{Ham's Closed Approach to Interpretation}

Fundamentalist approaches to interpretation are surprisingly unsystematic in appropriating meaning from biblical texts. Recent scholarship on conservative evangelical and fundamentalist interpretation has shown that these groups often see themselves as carrying on a tradition of interpretation, but in fact they lack a systematic interpretive tradition. ${ }^{98}$ Rather, they tend to selectively shift back-and-forth between

\footnotetext{
${ }^{96}$ Ibid., 357.

${ }^{97}$ Ibid., 397.

98 Three scholars have identified this phenomenon in evangelical and fundamentalist cultures and have used the term "biblicism" in an effort to describe such an approach to interpretation. See Brian Malley, How the Bible Works: An Anthropological Study of Evangelical Biblicism (Walnut Creek, CA: Alta Mira Press, 2004); James S. Bielo, Words Upon the Word: An Ethnography of Evangelical Group Bible Study (New York: New York University Press, 2009); and Vincent Crapanzano, Serving the Word: Literalism in America from the Pulpit to the Bench (New York: The New Press, 2000).
} 
literal and figurative to support a theological doctrine that is prior to the interpretive process. James Barr's historic study on fundamentalism identifies this same tendency.

Even if fundamentalists sometimes say they take the Bible literally, the facts of fundamentalist interpretation show that this is not so. In order to avoid imputing error to the Bible, fundamentalists twist and turn back and forward between literal and non-literal interpretation. ${ }^{99}$

The process is often referred to by fundamentalists as a "literal" form of interpretation, but even such an alleged literal reading inevitably becomes inconsistent at certain points.

One easy example is the claim by YECs that God's resting on the seventh day of creation was not literal rest because an omnipotent and spiritual being cannot be physically tired. ${ }^{100}$ Another non-literal statement is made in the dialogue between God and Cain in Genesis 4. The statement, "Listen; your brother's [Abel's] blood is crying out to me from the ground," is explained by a CM source as non-literal. ${ }^{101}$ There are numerous examples of this sort of literal/non-literal interpretation that I will deal with as I interact more with the actual exhibits in the following chapter.

Vincent Crapanzano has done the most thorough job in explaining how fundamentalists and evangelicals use the term "literalism." He offers ten features of this usage:

1. It focuses on the referential or semantic dimension of language - more specifically on the word - rather than on its rhetorical or pragmatic (that is, its context-relating) dimensions.

2. It assumes a simple, unambiguous correlation of word and thing.

3. It insists on the single, the essential, the "plain, ordinary, commonsense" meaning of the word.

4. It believes that the meaning of a text, is ultimately decidable.

${ }^{99}$ James Barr, Fundamentalism (Philadelphia: Westminster Press, 1978), 40.

${ }^{100}$ Answers in Genesis provides an alternate explanation for the term translated "rest" in Genesis 2:3. One explanation is found on the AIG website: http://www.answersingenesis.org/articles/cm/v21/n3/seventh-day-eternal (accessed May 13, 2013).

${ }^{101}$ Tim Chaffey, "How Should We Interpret the Bible?" How Do We Know the Bible is True, vol. 1, ed. Ken Ham and Bodie Hodge (Green Forest, AK: Master Books, 2011), 131. 
5. It finds figurative understanding distorting, even corrupting. Or it contains such figuration in special genres, like "poetry" or "parable," which limit its extension.

6. It stresses authorial intention — “original intention"- - as an indicator of right meaning.

7. It views certain texts as fundamental - as grounding meaning.

8. Its practitioners are given to quoting or citing such texts on all manner of occasions.

9. It gives priority to the written - the text - over the spoken and in the case of sacred texts like the Bible, at times over experience.

10. Its proponents argue for the most part that a text must be interpreted in its own in [sic] terms before it can be applied to a particular situation. In other words, they tend to separate exegesis, interpretation, and application from one another rather than conjoin them in a single, mutually enriching movement. ${ }^{102}$

In researching the CM's publications as well as exhibits, video presentations, and lectures, I find Crapanzano's list to be amazingly accurate in describing Ham's interpretive approach. Further, Crapanzano identifies these tendencies to be at odds with an "openness" in approaching ancient texts. "Openness and indeed relativism are frequently contested, not in terms of the issues at stake, but in assertions of simplistic interpretive modes, like the literalist. An arid hermeneutics comes to substitute for live moral, political, and intellectual debate."103 Such "arid" and "non-open" tendencies aptly describe the closed hermeneutic practiced at the CM.

Although a single book on hermeneutics is not to be found at the CM bookstore, there are several brief chapters on interpretation in a select few CM publications. ${ }^{104}$ At this point, I will mention the features that Crapanzano has proposed (points 1 through 10, above) as they arise in the three sources cited below. Crapanzano notes that not all of

${ }^{102}$ Crapanzano, Serving the Word, 2-3.

${ }^{103}$ Ibid., 2.

104 Tim Chaffey, "How Should We Interpret the Bible?" in How Do We Know the Bible is True, vol. 1, ed. Ken Ham and Bodie Hodge (Green Forest, AK: Master Books, 2011), 121-37; Brian H. Edwards, "How To Understand the Bible: Hermeneutics, a Key to Treasure," in Nothing But the Truth: The Inspiration, Authority and History of the Bible Explained (Darlington, England: Evangelical Press, 2006), 318-55; Todd S. Beall, "Contemporary Hermeneutical Approaches to Genesis 1-11," in Coming to Grips with Genesis: Biblical Authority and the Age of the Earth, ed. Terry Mortenson and Thane H. Ury (Green Forest, AK: Master Books, 2008), 131-62. 
these ten features are always involved in literalist interpretation but rather, are "family resemblances" among fundamentalist and evangelical interpreters. ${ }^{105}$ In three books sold at the CM, I have identified assertions that match numbers 1, 2, 3, 4, 5, 6, and 10 from Crapanzano's list. Literalism is a style of interpretation rather than a systematic methodology. I have found systematic approaches to hermeneutics to be problematic for those who approach the Bible with presupposed doctrines, especially one such as inerrancy. In fact, the title to one of the books listed above, How Do We Know the Bible is True, hints that the major premise for $\mathrm{CM}$ advocates is the infallibility of the Bible. Judging by the positive reactions from audiences — usually impromptu applause — this is also the premise that gains the most traction when Ken Ham speaks about creationism. Ham has developed several central premises for his interpretation of Genesis 111. He has actually employed an ingenious set of premises that hardly any inerrantists can take exception to. In this way, Ham's popular discussions about Bible interpretation - especially the six, literal days of creation and a young-earth - avoid technical jargon or detailed biblical studies and appeal more to those who are looking for clarity and certainty. At times, Ham does employ the majority of Crapanzano's identifiable features of literalism. However, he does so in a straight-forward and charismatic way.

The majority of my analysis will come in Chapters IV, V, and VI. At this point, I will sketch a brief outline of the major premises Ham uses to reaffirm Christians to accept his views of the Bible and science. These premises do not necessarily come in any order, however, the first and most important premise is that of biblical inerrancy. This view of the Bible holds that the original written documents of the Old and New

105 Crapanzano, Serving the Word, 3. 
Testament are completely free of any error-scientific, historic, or theological. Therefore, the Bible is the ultimate authority on everything which it addresses. Ham's second premise is that belief in the Bible (meaning every single verse) is contingent upon Genesis, especially chapters 1-11, as the foundational epistemological basis for all the other parts. Simply put, if Genesis 1 to 11 cannot be trusted as literal historic fact, then any other part of the Bible cannot be trusted — thus, God cannot be trusted. The third premise is that evolutionary theory is the single greatest threat to people's confidence in an inerrant Bible. Premise four is that the result of this lack of trust in the Bible and abandoning of moral absolutes has led society into a morass of social problems-such as abortion, pornography, lawlessness, gay marriage, etc. The fifth major premise is a solution to this moral decay. If people are taught to trust the young-earth creationist account of Genesis, then they will be emboldened to trust the Bible and will recapture the moral absolutes contained therein. The following quote is a summary of these premises in Ham's own words:

The more people believe in evolution and/or millions of years, and the more they reject the infallibility [infallibility has essentially the same meaning as inerrancy] of God's Word beginning in Genesis, the more they will also begin to doubt Scripture and to reject the morality built on God's Word. Also, the more young people in the Church are led to believe they can start outside the Bible with man's fallible ideas, such as evolution and millions of years, the more they will be consistent and take man's fallible ideas about morality and reinterpret what the Bible clearly teaches about such matters. ... And this undermining [of the Bible by Darwinism] is the issue; this is why we have lost biblical authority in the culture. $^{106}$

Ham's approach to hermeneutics can be quite cohesive and persuasive when his premises are accepted. Chapter IV will analyze the various ways in which this closed hermeneutic structure is presented most persuasively through visual and multi-sensory

${ }^{106}$ Ken Ham, The Lie rev. ed. (Green Forest, AK: Master Books, 2012), 139-40. 
exhibits at the CM. In fact, formal textual discussions of hermeneutics are on the extreme periphery of the CM and those that are there amount to a few chapters and website posts.

\section{$\underline{\text { Linguistics }}$}

\section{Fairclough's Building Coherence-Frames, Scripts, and Schemata}

Language is a crucial component of the overall message at the CM. Norman Fairclough's book, Language and Power, explores the multifaceted connections of the power of language. Fairclough addresses larger systems of political and economic power, but he has delivered some important tools for any analyst who is trying to describe how language is used within a particular group to bring real significance to their lives. Critical Language Study (CLS) is a sub-discipline of linguistics that analyzes, "social interactions in a way which focuses upon their linguistic elements, and which sets out to show up their generally hidden determinants in the system of social relationships, as well as hidden effects they may have upon that system."107 The following concepts, identified by Fairclough, are important in my analysis of the CM: coherence and frames, scripts, and schemata.

Coherence is a term used to describe how a text (written or spoken) makes sense to an interpreter. Coherence is described by Fairclough as a " fit' between text and world." ${ }^{108}$ Coherence requires two important connections: "(i) between the sequential

${ }^{107}$ Norman Fairclough, Language and Power $2^{\text {nd }}$ ed. (New York: Pearson, 2001), 4. I would add the note that Fairclough treats Critical Discourse Analysis (CDA) as a type of Critical Language Study (CLS). CLS and CDA are essentially synonyms. CLS was used in the first edition of Language and Power as Fairclough sought to better establish a systematic way of doing what was, in the 1970's, called "critical linguistics" (CL). As Language and Power influenced linguistic researchers and ethnographers and became more refined, CDA was adopted to describe what essentially became a new field of research. Norman Fairclough's Critical Discourse Analysis: The Critical Study of Language $2^{\text {nd }}$. ed. (New York: Pearson, 2010) was the title of the more developed system of CDA.

${ }^{108}$ Fairclough, Language and Power, 65. 
parts of a text; and (ii) between (parts of) a text and 'the world."'109 The first

connection - between the sequential parts of a text — is embedded in the hermeneutical task of filling in gaps in a text, based on inferences. "Implicit assumptions chain together successive parts of texts by supplying 'missing links' between explicit propositions, which the hearer/reader supplies automatically or works out through a process of inferencing." 110 This may be observed in the following example from Ham's book The Lie:

The culture is changing from one permeated by Christian absolutes (e.g., marriage is one man for one woman, abortion outlawed as murder, and so on) to one of moral relativism (e.g., marriage redefined to allow for same-sex unions, abortion legalized as a woman's right, and so on). In fact, consider just some of the changes that have occurred in the United States:

- In 1962, school prayer was ruled unconstitutional.

- In 1963, Bible reading in public schools was ruled unconstitutional.

- In 1973, restrictions on abortion were lifted, and abortion clinics began to permeate this nation (Roe v. Wade).

- In 1985, nativity scenes in public places were ruled to violate the socalled separation of church and state.

- In 2003, laws against homosexual sodomy were ruled unconstitutional. ${ }^{111}$

In this rather vitriolic quote, one may observe numerous implicit assumptions required to make sense of the text. For a reader to agree with the point of view of the author, she would need to at least grant the following assumptions. First, the Christian absolutes to which the writer alludes are quite narrow_-views on gay marriage and abortion as morally wrong. So the reader must grant primarily conservative, Protestant, and evangelical views of these two subjects. Second, it assumes there was a timepresumably before 1962 - that the culture was permeated by Christian absolutes. Third, it assumes the worst possible assumptions about the need to provide for religious plurality.

\footnotetext{
${ }^{109}$ Ibid., 65.

${ }^{110}$ Ibid., 67.

${ }^{111}$ Ham, The Lie, 139.
} 
This is hinted at in the pejorative reference to the "so-called separation of church and state."112

The second of Fairclough's connections needed for coherence is "between (parts of) a text and 'the world.", ${ }^{113}$ Here, connections are made between parts of a given text and an overarching view of how a preconceived world is intended to function. The parts of a text are often presented as reasons to explain why a certain situation is taking place. Using the same quote from Ham (p. 49, above), a pejorative view of the world is connected with a certain reduction of traditional Christianity in North America. The text will only explain the world to the degree that one shares the same views on the moral issues listed by Ham. Each issue is selected to present a negative trend in society. One must first view each issue as negative in order for Ham's argument to work. The list of societal changes is intended to show that the world is getting worse in a moral sense. "Moral relativism" is an extremely pejorative term for fundamentalist Christians.

This short quote from Ham is a microcosm of the overarching logic of the CM. Fairclough's two elements required for building coherence are present throughout the museum and will be referenced frequently_especially in Chapter V, "Causes and Solutions to Corruption." As may be identified in Ham's quote above, Fairclough describes the way coherence works: "Implicit assumptions chain together successive parts of texts by supplying 'missing links' between explicit propositions, which the hearer/reader either supplies automatically, or works out through a process of inferencing.",114

\footnotetext{
${ }^{112}$ Ibid, [emphasis mine].

${ }^{113}$ Fairclough, Language and Power, 65.

${ }^{114}$ Ibid., 67.
} 
Additionally, the inferencing to which Fairclough refers also depends on "background assumptions and expectations" $" 115$ that the hearer/reader brings to a text. These important considerations are described by Fairclough:

The sense or coherence of a whole text is generated in a sort of chemical reaction which you get when you put together what's in the text and what's already 'in' the interpreter - that is, the common-sense assumptions and expectations of the interpreter, parts of what I have called 'members' resources' (MR). ${ }^{116}$

This idea of coherence is a helpful way to understand and analyze how the CM constructs a linguistically cohesive view of the world. Someone not familiar with the background assumptions and expectations $\mathrm{CM}$ visitors might see the structure as fragmented and disparate. However, when certain premises are explained, it should become clear as to how such a coherent whole is created and maintained in the minds of creationists.

The two parts that form coherence, “(i) between the sequential parts of a text; and (ii) between (parts of) a text and 'the world,"' include the selected parts of the Bible and of natural phenomena and the unifying of these selected parts to form a match between the biblical texts and the world at large. This unifying coherence involves the selective presentation of certain parts of the Bible and the material world that fit an overall religious schema. This selectivity will be dealt with below when I introduce the concept of "screening" information.

Fairclough's explanation of "common sense" as one aspect of MR also serves as a useful tool in looking at the shared assumptions between devotees of YEC. It is my hypothesis that the coherence of a YEC worldview involves connections between selective slices of the world mixed with a certain sequence formed from parts of the biblical texts. Coherence derives from the narrative structure which offers to interpret and

\footnotetext{
${ }^{115}$ Ibid., 65.

${ }^{116}$ Ibid., 65.
} 
to explain the world. Moreover, this complicated interplay of context (social conditions), interaction (production and interpretation), and text (the thing produced/interpreted) simultaneously produce and interpret. This dynamic of production/interpretation will be explained later as typical of how religious communities function as complex adaptive networks. At the same time, Gadamer's identification of hermeneutic horizons could be adapted so as to fit into this schema as well. What Fairclough calls MR are ideas that he says are "already 'in' the interpreter." ${ }^{117}$ This is essentially the same idea that Gadamer calls "prejudice" (Vorurteile). Such prejudices are projected onto the text one is reading.

The second set of terms Fairclough provides are frames, scripts, and schemata. These three terms are organizational concepts proposed for his fourth level of interpretation - “text structure and point."118 As Fairclough explains, this level of interpretive analysis provides a picture of how "a whole text hangs together, a text's global coherence. This involves matching the text with one of a repertoire of schemata, or representations of characteristic patterns of organization associated with different types of discourse." 119 This aspect of coherence involves the interrelations of how frames, scripts, and schemata work together.

Frames will include particular exhibit types such as the lecture hall, planetarium, diorama, video documentary, and others. Fairclough defines a frame as "a representation of whatever can figure as a topic, or 'subject matter.'"120 Frames carry with them certain expectations. For example, a planetarium is a place or location of learning new ideas about planetary motion and the cosmos. We travel to a planetarium ready to see inspiring

\footnotetext{
${ }^{117}$ Ibid., 65

118 Ibid., 120.

119 Ibid.

${ }^{120}$ Ibid., 132.
} 
scenes from deep space and to be given information that non-specialists would not know. So the frame would be the structure of the planetarium. A joke, an academic lecture, a set of military orders, and many other forms of discourse assume different discursive roles. Frames also take place as an active process - in a conversation, lecture, telephone call, etc. In this sense, frames are highly interactive structures.

The second, closely related term "scripts" are the subjects involved in discourse and their relationships to one another. ${ }^{121}$ Here I plan to look at scripts as the "voices of authority" or those who produce the messages of the CM. A script can be thought of as a role played in certain activities. For example, the roles or scripts of professor and student, or of a doctor and patient are commonly identifiable. Authoritative scripts at the CM will include lecturer, scientist, astronomer, biblical scholar, etc. The other script-group will be visitors or the laity. In this group I am interested in "true believers" and not researchers such as myself or skeptics. The visitor scripts most commonly take the forms of student and/or lay church member.

Scripts and frames work together to provide context for a particular discourse. Authoritative scripts will include those voices that give the official interpretation of the text and the world. Behind all of these scripts is the final authoritative voice of Ken Ham. One important aspect of scripts involves the relationships between the authoritative voices and lay audiences. Roles are played out in various subtle ways, such as the frame of a lecture. The authority speaks, usually a monologue, and the visitors, now in the role of students, listen to and ask questions of the expert. As I will discuss in Chapter VI, the $\mathrm{CM}$ presents itself as the ultimate voice of authority because it claims to establish the

\footnotetext{
${ }^{121}$ Fairclough notes that frames and scripts are closely related concepts and that they sometimes overlap. For instance the script of doctor/patient is carried out in the frame of a doctor's office or emergency room-Ibid.
} 
only reliable epistemological foundation for all knowledge. Authoritarian scripts are one aspect of discourse as they dictate the terms, contexts, and organization of information delivered to visitors.

At the CM, a suitable way to identify Fairclough's idea of a schema (schemata plural) is through the concepts of God, self, and world. Schemata are the most abstract of the three terms-frames and scripts are easier to identify. Fairclough defines "schemata" as "mental typifications of structures which operate as interpretive procedures." ${ }^{122}$ As such, these mental types provide a framework of organized patterns of thought from which to interpret certain data. One such important schema for fundamentalist Christians are the concepts of God, self, and world. The typical pattern in this schema is dualism. The ultimate duality for this type of view is a separation between the realm of the perfect (to include God) and the realm of the fallen (the physical universe, especially planet earth). The ultimate ground of reality is God. This view also holds to a transcendent God who is existentially other than the created cosmos. Thus, the dualist structure becomes one of ultimate reality/God versus the physically corrupt and illusory/world. Because of the fallen nature of creation, all "truth" is somehow masked or inaccessible to created beings and is only fully present in the realm of God.

The concept of "self" in this schema pertains to how the individual person views their own relation to God and world. To borrow from Reformation parlance, total depravity, due to the fall, has caused all knowledge to become unreliable and subject to misinterpretation. The human mind is understood as incapable of arriving at truth without the help of God. But God must break through this barrier of transcendence and he does so through special revelation. As one scholar has noted: "Since there is no direct, essential,

${ }^{122}$ Ibid. 
or implicit association with the real, the relation to and awareness of it are not immediate but must be mediated ... through intermediaries like prophets, saints, and messiahs or in rituals and oral and written sacred texts."123 This idea of authoritative revelation coming through authorized spokespersons is one of the most central ideas of fundamentalism and is also a major premise at the $\mathrm{CM}-\mathrm{a}$ focus of Chapter IV. So the fundamentalist concept of self includes the need for an interpretive lens through which to correct the corrupted data of this present, fallen world. This lens is the Bible.

In fact, in Ham's most popular book, The Lie, a cartoon illustration actually presents the Bible as an actual lens which is being held up to interpret a fossilized skull (Figure 4, below). In the cartoon, another lens, labeled "Man's Theories," is also shaped like a book and is used to interpret the skull from a different perspective.

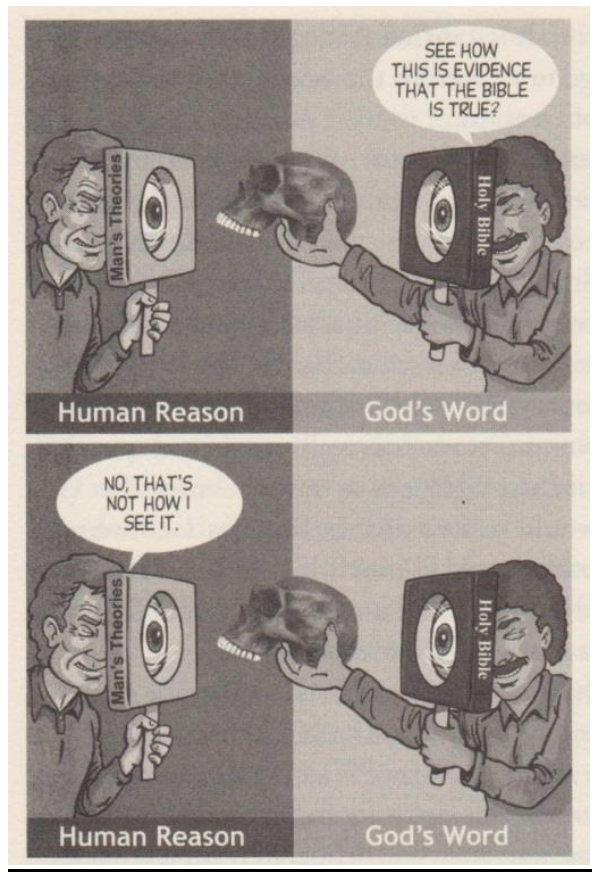

Figure 1. Ken Ham, The Lie Rev. Ed. (Green Forest, AR, 2012),73.

${ }^{123}$ Taylor, After God, 39. 
This cartoon illustrates the idea that all physical data is subject to misinterpretation because the self, which is fallen and sinful, cannot properly interpret data without the help of divine revelation. Ham explains:

Thus, it is God who lets us see the truth-lets us see that the evidence is all there - that He is Creator. However, in a very real sense, there has to be a willingness on our part to see as well. Why can the humanists, the evolutionists, not see that all the evidence supports exactly what the Bible says? It is because they do not want to see it. It is not because the evidence is not there. They refuse to allow the evidence to be correctly interpreted in the light of biblical teaching. ${ }^{124}$

Ham's quote shows how the unsaved self, also labeled "humanist" or "evolutionist", is perceived as corrupted to such a degree that any evidence will be misinterpreted because of the lack of willingness to see things through the biblical lens. The willingness, as Ham describes, only comes through salvation. But this salvation is only fully actualized through a young-earth creationist reading of the Bible.

This is an incredibly circular argument and one that is closely tied to conspiracy theory. ${ }^{125}$ Simply stated, the only ones who can see the truth of YEC and the falsehood of evolution are those who have been spiritually redeemed. Therefore, the self is divided into the typical dualist category of the saved (enlightened) and the unsaved (unenlightened). A person cannot begin to see the truth until spiritual regeneration has occurred. All others fall into the category described by Ham: "They refuse to allow the evidence to be correctly interpreted in the light of biblical teaching." "126

In addition to God and self, world is dualistic as well. There is a fine line between the concepts of self and world. Because people are part of the world, the self is really not

${ }^{124}$ Ibid., 75-6.

${ }^{125}$ Ella Butler identifies one form of public discourse at the CM as that of "conspiracy theory." She shows how authoritative scientific voices are explained away as part of the conspiracy against religion. "God is in the Data: Epistemologies of Knowledge at the Creation Museum," Ethnos 75 (September 2010): 229-51.

${ }^{126}$ Ham, The Lie, 75. 
distinct from the world. However, the idea of a spirit/soul created in the image of God allows a mystical point of connection between the self and God. In this schema, the self is redeemable and may be able to stand in the transcendent presence of God-but not in this life. World as a schema is viewed as both corrupted as well as in the process of becoming more corrupted. The eschatological position of the earliest YECs (Price, Whitcomb, and Morris) was staunchly dispensational pre-millennialism. ${ }^{127}$ An important note about such eschatological positions is that they view the present world as temporary. That is to say, the present world is going to be destroyed in a final apocalyptic destruction. So the present world is temporal.

In addition to being temporal, the physical world is also unknowable apart from God's revelation. The reason for this lack of knowledge is twofold. First, the history of the world can only be known through the Bible because it claims to be delivered by God who alone knows what happened in all past ages. The Bible is the one true corrective for all other competing metanarratives. Second, because humanity is depraved and subject to fallible conclusions when looking at physical evidence, scientific explanations about the past must conform to revelation in the Bible. So the schematic concept of world is one of instability. The dualist world is both undecipherable because of the fall and is temporal because God will ultimately destroy it.

${ }^{127}$ Dispensational pre-millennialism is an eschatological position that became popular among fundamentalists in the early twentieth century. Based on the teachings of Irish minister John Nelson Darby (1800-1882), dispensationalism asserts a radical discontinuity between the Old and New Testaments of the Bible. Dispensationalists advocate a new dispensation called the "church age" to be the time period between Pentecost in Acts 2 and the Rapture of the church which is still in the future. Secondly, premillennialism anticipates an actual, physical and bodily thousand-year reign of Jesus Christ on the earth after the rapture. Dispensational pre-millennialism has been a central feature of Protestant, North American fundamentalism. See George Marsden, Fundamentalism and American Culture, $2^{\text {nd }}$ ed. (Oxford: Oxford University Press, 2006): 43-71. 
Because the world suffers from what theologians refer to as the noetic effects of sin, every aspect of the physical world has been subjected to corruption and misinformation. For this reason, proponents of the CM position would actually prefer that theology return to the medieval status of "queen of the sciences." However, some contradictions arise here as well. The theological view of revelation from two books (the book of nature and the book of scripture)—one that medieval and Reformation theologians embraced - has been abandoned only recently by YECs. ${ }^{128}$ The book of nature or general revelation is truncated to a category that only reveals the existence of God and nothing further. Thomistic theology was much more friendly to general or natural revelation and to what later became natural science.

Schemata are described by Deborah Tannen as "knowledge structures in the minds of participants in interaction — expectations based on prior experience about objects, events, and settings."129 This is essentially the same idea of schemata as defined by Fairclough: "Schemata are mental typifications [sic] of such structures which operate as interpretive procedures." ${ }^{130}$ I will endeavor to show how the schema of God, self, and world is the central knowledge structure that YECs bring to the interpretive endeavors at the CM. Further, it should become clear how the discourse at the CM harmonizes with such a religious schema. Fairclough's other categories of frames and scripts operate dynamically to reinforce and to make sense of this particular God/self/world schema. Fairclough notes that the categories of frames, scripts, and schemata overlap. "This

\footnotetext{
${ }^{128}$ Ronald L. Numbers, "Reading the Book of Nature Through American Lenses," in The Book of Nature in Early Modern and Modern History, eds. Klaas Van Berkel and Arjo Vanderjagt (Leuven, Belgium: Peeters, 2006), 270.

${ }^{129}$ Deborah Tannen, "Frames and Schemas in Interaction." "Quaderni di Semantica's Round Table discussion on frame/script semantics," ed. By Victor Raskin. Quaderni di Semantica 6 (1985): 2.238. ${ }^{130}$ Fairclough, Language and Power, 132.
} 
[overlap] is to be expected, because the three terms identify three very broad dimensions of a highly complex network of mental representations." "131

At the CM, these variously constructed frames of discourse assume unique roles. My analysis, especially in Chapter V, will elaborate on numerous distinctive frames and the discourse that arises when the scripts interact. For a few initial examples, the CM contains two lecture halls - the Morris and Whitcomb Lecture Rooms and Discovery Hall. The terms "lecture room" and "hall" are typically used on college and university campuses. The title of the rooms frame them as places in which one is lectured. Lectures also assume a certain authoritative script. Some regular lectures feature the professorial scripts of Dr. Georgia Purdom and Dr. David Menton. ${ }^{132}$ Additionally, the rooms are arranged as classrooms. They contain rows of desks, podiums, digital projectors, and display tables for scientific specimen. The expectation in such a setting is one of learning from an expert teacher or lecturer.

Another such frame is that of the Stargazer's Planetarium. Sophisticated equipment and seating project the expectation of competent astronomical instruction. Dramatic video footage, scientifically sophisticated photos of deep space, and an articulate audio narrative all provide the visitor with the expectation of learning about the workings of the cosmos. One enters a planetarium with the expectation of seeing wonderful sights of the cosmos that the unaided eye cannot attain.

A wider frame is at work as well. The idea that the entire facility is a museum is an over-arching frame. A detailed discussion of the concept of a museum will be the primary focus of Chapter VI. It should be noted that the smaller frames-planetarium,

\footnotetext{
${ }^{131}$ Ibid.

132 These and other authoritative staff members will be discussed further when I address Fairclough's notion of scripts.
} 
lecture hall, botanical gardens — could be thought of as "frames within a frame." The important point here is that expectations for certain forms of authoritative discourse are built-in to the context of each particular frame. When someone comes to these frames with the schema of God/self/world described above, they are able to see the coherence of the whole, or, in Fairclough's words, "to establish a fit between text and world." 133

Much of the discursive activity that transpires at the CM is straightforward and functions most effectively on a common-sense level. ${ }^{134}$ The messages of the CM resonate for a particular schema of religious expectations. The bits of information used are presented as the biblical story of history - a metanarrative to replace all others.

One of my hypotheses is that the CM message is persuasive for many people who feel threatened by the increase of information and global connectivity. With the increase in ethnic and religious diversity in American culture, a great deal of instability affects many Christian conservatives by projecting an image of a "culture in crisis"- this phrase is the actual name of one room at the CM. If a particular crisis is assumed, the answers to solve the crisis provide coherence and purpose for true believers. The CM provides discourse that offers to explain the causes of evil in the world and to propose a solution to evil - the primary subject of Chapter V. Consequently, a discourse of certainty is developed.

${ }^{133}$ Ibid., 65.

${ }^{134}$ Common sense is a widely used term in both scholarly and popular literature. The range of meanings assigned to the term is also broad. I will use the term as defined by discourse analysts Norman Fairclough and Teun A. van Dijk. Van Dijk defines common sense in much the same terms as Fairclough: "Here common sense is simply defined in terms of implicit social knowledge that group members take for granted in their everyday practices. This members' knowledge is essentially shared lay-knowledge, and should be distinguished from elite or theoretical formulations or explications of knowledge." Teun A. van Dijk, Ideology: A Multidisciplinary Approach (London: Sage Publications, 1998), 102. To be clear, Fairclough also includes common sense as part of what he calls members' resources, Language and Power, 65 . 
Fairclough identifies four levels of the interpretive process: surface of utterance, meaning of utterance, local coherence, and text structure and point. My analysis will mostly deal with the level of text structure and point. Fairclough defines this fourth level as "how a whole text hangs together ... matching the text with one of a repertoire of schemata." ${ }^{135}$ This level works well with the different frames, scripts, and schemata that I have identified above. Coherence is achieved when the script of a lecturer arrives to deliver a lecture in the frame of a lecture hall. The God/self/world schemata is then matched with the particularities uniting the world of YEC through the discourse of the lecture. Moreover, the CM effectively matches parts of the biblical text to parts or episodes of current or world history.

Challenges to assumed schemata require stringent amounts of mental effort in order to amend or modify the existing paradigm. Most common-sense assumptions are relatively reliable for everyday tasks, such as filling the car with gas or buying milk at the grocery store. On most levels, esoteric information and theory do not help us accomplish everyday tasks. There is a certain counterintuitive element in trying to think phenomenologically about other views of reality—especially ones that are thousands of years old. One such common example occurred in a graduate seminar in sociolinguistics. I made the off handed comment that every physical thing was spinning at extremely fast speeds. I received quite a few puzzled looks and a few verbal scoffs. The frowns and questions went away when I went on to explain that I was talking about the properties of Quantum Chromo Dynamics. Even when one reads summary reports by quantum physicists, these concepts seem nearly impossible on the common-sense level. A further hypothesis is that the CM resonates much more clearly for an audience of non-

${ }^{135}$ Ibid., 120. 
specialists. ${ }^{136}$ This is all the more true for those with limited exposure to biblical and scientific specialists. Thus, the CM has the enormous advantage of creating a narrative that is already taken for granted by those who have a dualist God/self/world schema at work. Fairclough reminds that "[s]chemata are a part of MR [member's resources] constituting interpretive procedures." ${ }^{137}$ Visitors to the CM who have this religious schema are primed with common-sense assumptions and expectations.

To summarize the elements of Fairclough's approach, I will use coherence as the goal of the discourse at the CM. They are attempting to achieve through language exactly what Fairclough calls global coherence- "how the parts of a text [the Bible] link to each other... [and] to how the text fits in with your previous experience of the world." ${ }^{138}$ With the dualist God/self/world schema described above, the CM stitches together a metanarrative to accomplish the following tasks: to explain the pre-patriarchal narratives as a material and historical account of the universe; to offer an explanation and solution for evil and corruption; and to demonstrate that evolutionary science is completely false.

${ }^{136}$ I base this hypothesis not only on observation, but also on a recent book that stresses the counterintuitive nature of science: Robert N. McCauley, Why Religion is Natural and Science is Not (Oxford: Oxford University Press, 2011).

${ }^{137}$ Fairclough, Language and Power, 131.

${ }^{138}$ Ibid., 65 . 


\section{Information Theory}

\section{Taylor's Screening of Information}

Information Theory (IT) is a wide domain of study in the sciences and in the social sciences. Mark C. Taylor has been exploring IT and how it applies to religious culture for over two decades. IT has impressed me because I see it as a refinement of Hegel's dialectic. ${ }^{139}$ The basic dialectic view of history is one that I have found to be reliable, especially when looking at historical change between cultures. The basic structure of IT deals with how information is processed. Therefore, hermeneutics and linguistics are central parts of the discussion of these processes. Two concepts in IT are important for my analysis - complex adaptive networks (CAN) and screening of information. ${ }^{140}$

Taylor uses Nobel laureate and physicist Murray Gell-Mann's definition for complex adaptive networks ("system" is sometimes used interchangeably with “network"). ${ }^{141}$ Schemata are comprised of interlaced networks of various types of information. For example, culture (comprised of art, philosophy, and religion) interacts with nature (comprised of chemistry, physics, and biology). There are many differing schemata all interacting between information systems (see Figure 1, below ).

\footnotetext{
${ }^{139}$ Taylor makes more references to G. W. F. Hegel than any other thinker in the book. Mark C. Taylor, After God (Chicago: The University of Chicago Press, 2007).

${ }^{140}$ Complex adaptive networks are dealt with most thoroughly in Taylor's book After God. The idea of "screening information" is the title of Chapter 7 of his earlier book. Mark C. Taylor, The Moment of Complexity: Emerging Network Culture (Chicago: The University of Chicago Press, 2001).

${ }^{141}$ Gell-Mann's definition is as follows: "... a complex adaptive system acquires information about its environment and its own interaction with that environment, identifying regularities in that information, condensing those regularities into a kind of "schema" or model, and acting in the real world on the basis of that schema. In each case there are various competing schemata, and the results of the action in the real world feed back to influence the competition among those schemata." Murray Gell-Mann, The Quark and the Jaguar: Adventures in the Simple and the Complex (New York: W. H. Freeman, 1994), 17.
} 


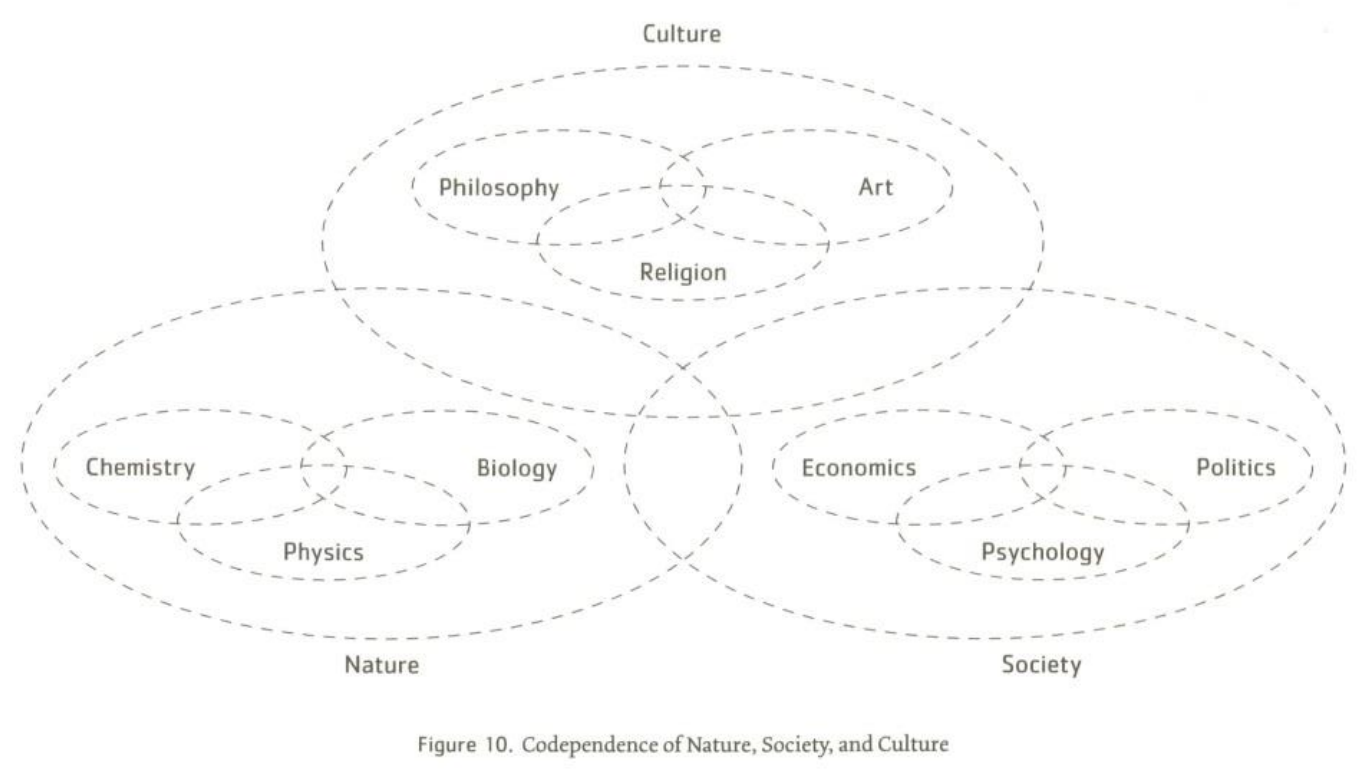

Figure 2. Mark C. Taylor, After God (Chicago: The University of Chicago Press, 2007), 25.

These schemata are in a constant state of revision as new information is always being processed. Because of the interconnected nature of these domains, information influences all other domains to some degree. Most of the time, these revisions are small, micro-level adjustments that often go unnoticed. Large, macro-level revisions in schemata do not happen as frequently. For example, major paradigm shifts like the change from the Ptolemaic to the Copernican system or the shift from steady state theory to big bang cosmology, happen once in a great while.

At the most basic level, information is always being "figured" or constructed according to temporary patterns that emerge at the interface between an existing pattern and data/noise. Taylor illustrates how a current paradigm or schema will be de-stabilized by an influx of new information from other schemata that cross disciplinary lines. This 
destabilization will eventually be reconfigured to form a new informational paradigm or schema. As diagramed in Figure 2, this process is in constant flux.

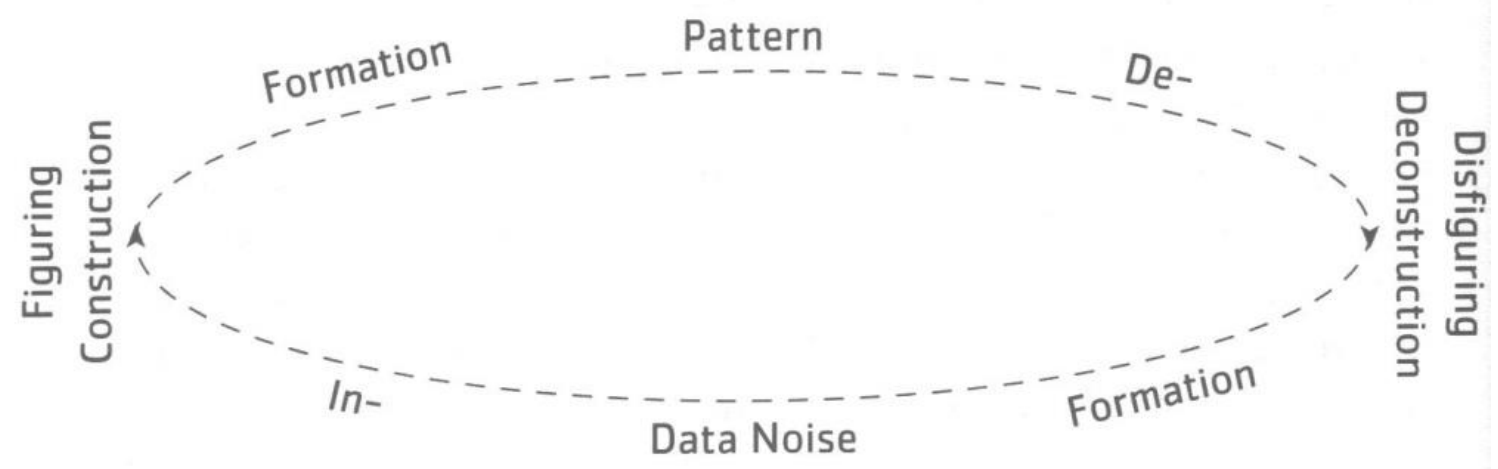

Figure 9. Imagination

Figure 3. Mark C. Taylor, After God (Chicago: The university of Chicago Press, 2007), 28.

The two codependent sides that comprise this process are described as "pattern" and "data/noise." Data/noise is a form of information as is the existing pattern, but noise refers to information that challenges or calls into question an existing pattern. A pattern is the refined or modified—most of the time, ever so slightly—information which reconfigures the data/noise with a more functional and efficient emerging pattern.

The overlapping influence of different domains of information—visually diagramed in Figure 1 (above) — takes into account the interconnectedness of knowledge. As Taylor describes, a religious schema of symbol, myth, and ritual is in a relational web with other human expressions such as art and philosophy. These cultural webs are then connected to natural and societal webs. For example, a breakthrough in the sciences may well influence breakthroughs in psychology, economics, and politics. These may in turn 
cause structural shifts in religion, art, and philosophy. Evolutionary biology is one such example. ${ }^{142}$ With an approach to religion such as Taylor's, one is better able to take into account the range of cultural, natural, and societal influences on a particular religious group.

Influxes of new information are sometimes threatening to existing schemata because they always challenge the soundness of a given pattern. Applying the dynamics of complex adaptive networks to define religion, Taylor writes the following:

Religion is an emergent, complex, adaptive network of symbols, myths, and rituals that, on the one hand, figure schemata of feeling, thinking, and acting in ways that lend life meaning and purpose and, on the other, disrupt, dislocate, and disfigure every stabilizing structure. ${ }^{143}$

This definition is central to my analysis of the CM because it helps to explain the threat of new information - in this case, evolutionary science - to an existing religious schema. The definition also provides a wider context for looking historically at religious reactions when new information challenges an existing schema.

Taylor's theory also provides a certain degree of explanatory strength when looking at fundamentalist groups and their tendency to react to a rapidly changing culture. As new information challenges an existing paradigm, a tendency toward insularity and preservation occurs. In Taylor's words, “As the threat of disruption increases, devotees tend to absolutize, reify, or fetishize their beliefs and practices. When this occurs, religion devolves into a religiosity that resists the new by clinging to the

${ }^{142}$ Evolutionary theory is used in cognitive science-see Steven Pinker, The Better Angels of Our Nature: Why Violence has Declined (New York: Viking, 2011) - to explain social trends like declining violence. Evolutionary theory is used in psychology—see Jonathan Haidt, The Righteous Mind: Why Good People are Divided by Religion and Politics (New York: Pantheon Books, 2012) - to explain trends in religion and politics.

${ }^{143}$ Taylor, After God, 12. 
old." 144 The CM attempts to do this very thing by insisting upon a young earth. The implicit message is that society was better (physically, morally, and spiritually) when most people believed in a young earth. ${ }^{145}$ While this time and place is never identified nor located, the message is clear: Before Darwin, Christianity was much better off. Taylor's theory predicts what I have observed happening at the CM: "True believers set themselves apart from infidels by constructing an ideal past, which they believe, has been corrupted in the present. The goal becomes to 'recover' this past by purifying the present through the conversion or elimination of nonbelievers."

Taylor conducts a lengthy discussion of the importance of the categories of myth and theory in information processing. He writes: "Theory, on the one hand, abstracts from temporal development in an effort to determine universal truth, and, myth, on the other, elaborates narratives to suggest general, if not universal, truths."147 Taylor explains that both theories and myths are symbol systems that help to explain something about the phenomenal world. The trouble with the viewpoint at the CM, as will be documented in future chapters, is that it attempts to merge ancient myth with modern scientific theory. A result is the ironic fictions that emerge in efforts to maintain or, in Taylor's words, "reify" such myths. A few examples are fictitious snakes, dragons explained as actual dinosaurs, and people living alongside dinosaurs.

In addition to the definition of religion in terms of complex adaptive networks, Taylor uses the term "screening" to describe one of the most basic dynamics of information processing. "Far from exclusive opposites, noise is both information waiting

${ }^{144}$ Ibid., 13.

145 "Most people" - as I use it in the sentence noted above - consists of the western Christian world as non-Christian cultures would be seen by the CM as corrupted and in need of saving.

${ }^{146}$ Ibid., 23.

147 Taylor, The Moment of Complexity, 211. 
to be screened and the remainder, refuse, or debris left over after screening occurs."

Screening is the process, consciously and unconsciously, of discharging irrelevant data while processing data that helps to form and refine an emerging pattern. ${ }^{149}$

The connection between these ideas and the $\mathrm{CM}$ is summarized in the following quote by Taylor:

At the conceptual level, ideas, categories, names, models, and paradigms pattern data mediated by the senses. Sensual perception, however, is never raw; it is always cooked according to recipes that bubble up in the stew of experience. Sensory filters can be both visual and auditory; images, pictures, representations, even logos and brands, as well as sounds, rhymes, jingles, tunes, and melodies structure awareness and direct attention. ${ }^{150}$

This "structured awareness" and "direction of attention" are what I am most interested in analyzing at the CM. Tannen also identifies these schemata in what she calls "structures of expectation." 151 In identifying the dynamic and co-evolving nature of schemata, Tannen quotes from Frederic Bartlett's influential book, Remembering: "the whole notion, that the organized mass results of past changes of position and posture are actively doing something all the time; are, so to speak, carried along with us, complete, though developing, from moment to moment." 152 Expectations are dealt with in a complex way at the CM. They are both shaped and manipulated in certain ways designed to reach only one conclusion. Part of this shaping involves screening-out whole areas of data to present a certain perspective.

${ }^{148}$ Taylor, The Moment of Complexity, 203.

149 I have tried to think about how screening of information works on several levels and have found it helpful to think in terms of intentional or conscious screening and unintentional or unconscious screening. Intentional screening is an active, self-conscious effort to sift through relevant content, like deciding what material to leave out in a class lecture. Unintentional screening is an unconscious competence that comes with everyday situations, like excluding irrelevant data while operating a vehicle.

${ }^{150}$ Taylor, The Moment of Complexity, 207.

${ }^{151}$ Deborah Tannen, ed. Framing in Discourse (Oxford: Oxford University Press, 1993), 15.

${ }^{152}$ Ibid., 16. 
One factor that makes analysis difficult is that myths are, in Taylor's words, "networks of networks" ${ }^{\text {"153 }}$ which are always challenged when new insights of the operational world are offered. This sets up tension for fundamentalists. To begin with, they do not like to call any part of the Bible "myth." To them, the Bible is an absolutely correct and descriptively accurate historical and scientific account of life on earth. Taylor describes what happens when new information/noise challenges such belief structures:

In the case of myths, noise is generated by experiences that cannot be adequately processed and by conflicts between and among different symbols and myths... The most conservative response to apparently discrepant experiences is to try to explain them through the accepted myth by providing reasons and explanations, which are not immediately obvious. When successful, this response serves to reinforce the stability of the myth. The fewer the alternative points of view, the more stable particular patterns of explanation tend to remain. ${ }^{154}$

This quote explains my hypothesis that the $\mathrm{CM}$ is an elaborate screen that excludes much more information — biblical and scientific - than it includes. It should be stated up front that the CM would not concede that any portion of Genesis 1-11 is mythical. But the denial that Genesis is mythic is a part of the effort to explain the threatened myth as referenced above. Second, much effort has been dedicated to explain away scientific findings (like the fossil record or distant starlight) in ways that multiply difficulties. Third, screening information in a highly selective way is essential to reduce alternative points of view in order to "reinforce the stability of the myth."155

Screening of information occurs in a myriad of ways at the CM. Something as straightforward as the lack of credentialed biblical commentaries on Genesis in the CM bookstore is one example. Not only are there no peer-reviewed commentaries on Genesis for sale, the bookstore does not even offer mainstream evangelical commentaries for

\footnotetext{
${ }^{153}$ Taylor, The Moment of Complexity, 212.

${ }_{155}^{154}$ Ibid., 212-14 [emphasis mine].

${ }^{155}$ Ibid.
} 
sale - including homiletic or expositional commentaries. Screening out the vast amount of scholarship, evangelical and secular, is essential in maintaining such a narrow and literal interpretation.

A more sophisticated way that information is screened is through the highly selective scenes in the main exhibits of the CM. One of the initial rooms in the museum's main exhibit is titled Biblical Authority. The purpose of this room is taken from a CM publication below:

Biblical Authority Room - At the Creation Museum, no apology is made about the fact that our starting point is the Bible. This Book is a written revelation from One who knows everything and who inspired His prophets and apostles to write down for mankind the true history of the world. Throughout the Creation Museum, observational science (biology, geology, etc.) is used to confirm that the Bible's history truly explains the world. This room gives examples of witnesses down through the ages who attest to the truthfulness of God's Word. ${ }^{156}$

The room contains mannequins of well-known biblical figures such as Moses, David, Isaiah, and St. Paul. There are scenes such as Martin Luther's Wittenburg Door exhibition as well as other highlights from church history. But the point of this room is summarized in one placard which reads as follows:

\section{God's Word is TRUE}

- 40 authors, writing over 2,000 years, spoke the SAME MESSAGE.

- Scrolls, discovered in the last century, confirm that the ORIGINAL WORDS have been preserved.

- Archaeology has repeatedly confirmed that the Bible's HISTORICAL DETAILS are accurate.

- Hundreds of BIBLE PROPHECIES have been fulfilled, and none has failed. ABOVE ALL, the GOD of TRUTH, the CREATOR of heaven and earth, inspired the men who penned the words. ${ }^{157}$

${ }^{156}$ Answers in Genesis, A Journey Through the Creation Museum (Green Forest, AR: Master Books, 2008), 31.

${ }^{157}$ The placard transcribed in this text box is taken from a personal photo inside the Biblical Authority Room at the Creation Museum, Petersburg, KY 2011. Photo: S. Watkins. 
I am sure that many fundamentalists and even a good number of evangelicals would have no problem affirming the statements on the placard. But as one who teaches church history and biblical studies, I am amazed at how much information is omitted. On the other hand, most lay Christians would never know just how much is left unsaid, and therefore screened. For example, the first premise - " 40 authors, writing over 2,000 years, spoke the SAME MESSAGE"-is one ultra-conservative estimate of how many people were involved in writing, copying, and editing, as there were likely far more than forty people involved in compiling the Torah (Genesis through Deuteronomy) alone. Two thousand years is also far from a consensus among biblical scholars-many of whom would estimate the time to be less than one thousand years. What is meant by "SAME MESSAGE" is also contentious. There are vastly different messages in the Tanakh alone, not to mention the epochal dissonance between the Old and New Testaments.

Further, it is not at all clear how the Dead Sea Scrolls ever confirm original letters that have never been found and were obviously written prior to those same scrolls. While some archaeological details do match biblical references, many do not and many others are still a mystery. The bible prophecy assertion is simply too broad to even make a cursory statement about. Teaching these subjects at a university allows me to quickly assess the enormous amount of information that is withheld in the placard. It would require hours of lecture to even survey the number of different scholarly positions held concerning the four bullet-points in the placard.

I cannot, however, honestly say that the writers of the placard deliberately withheld such important information because they may not even be aware of it 
themselves. In fact, if this were the case, it would be one example of what I call "unintentional screening." The fact that the CM lacks a single biblical scholar with a terminal degree could be considered a form of screening as well. Taylor notes that “...screening of information always begins below or beyond the level of consciousness." ${ }^{158}$ It appears to be the case that high degrees of screening can suppress critical inquiry indefinitely. Logically, one cannot process excluded information because it is simply absent. Keeping new information at bay reduces the risk of an existing pattern being challenged and overturned, but it also closes off the possibilities for new meaning. Similar to the case with hermeneutics, this could be thought of as a closed pedagogic system, because it presupposes the thing it seeks to prove.

A final note concerning the metaphor of screening is in order. Taylor uses the term as it occurs in all information processing. If his theory is correct, as I judge it to be, screening is necessary for the vast data/noise that everyone processes. Much of the screening we do on a practical level is nearly imperceptible. Taylor describes this aspect of information screening: "Since most of these data remain unprocessed, we are unconscious, though not necessarily unaware, of much of the information coursing through our bodies and minds." ${ }^{\prime 159}$ Even as I type these words, there are noises and stimuli that I am blocking out. To focus on those noises would draw me away from the task of writing and become another type of screen. This is why we find it preferable to study in a library or quiet space that limits the number of stimuli that can distract our concentration.

\footnotetext{
158 Taylor, The Moment of Complexity, 207.

${ }^{159}$ Ibid., 203.
} 
But intentional or conscious screening of information — as is the case in deciding what to include and what to leave out of a lecture-occurs on another level. Here I think it helpful to view the academy as a screen for the proper use of information. Peer review, when it works as it is supposed to, limits uncredible sources, thereby acting as a sort of proper screen. In fact, Francisca Cho and Richard King Squier have made the observation that scholarship itself may be understood as a CAN. ${ }^{160}$ This is not to say that all scholars agree on certain viewpoints or conclusions, but rather, that the proper use of all pertinent sources are at least consulted and acknowledged and that logical and non-fallacious inferences are drawn from these sources. I intend to show that one of the major screens occurring at the CM is the lack of peer reviewed material.

Chapter V_ “Science Redefined: Why a Museum?”-will warrant Taylor’s theory on religion as a CAN and screening as an attempt for the CM to resist the influx of scientific data that arises as a threat to the message of the CM. In one way, science creates the data/noise that challenges the constructed pattern created by the CM. Thus the threat as they perceive it is real. As Taylor has established, domains of knowledge influence one another in a web of networks. Theology, in this case of a medieval variety, cannot escape the cosmological and biological revisions that science will demand. So the $\mathrm{CM}$ attempts to redefine science itself.

The dynamics of Taylor's theory, as explained in this section will be primarily applied in Chapter V. Science is the information that threatens the theological paradigm.

\footnotetext{
${ }^{160}$ Francisca Cho and Richard King Squuier, "Religion as a Complex and Dynamic System," Journal of the American Academy of Religion 81 (June, 2013): 388.
} 


\section{Conclusion}

If Taylor's description of the dynamics of information processing are foundational for all forms of dialogue, then analysts who deal with these interactional processes are essentially exploring aspects of the same phenomena. Fairclough's CLS looks at the broader level of language in society (including texts and speech) and Gadamer looks at the more specific level of an individual interpreter and of that person's handling of a specific text (usually a written text). The commonality of Fairclough and Gadamer is that they both explore the processes of interpretation. Taylor applies the dynamics of information theory to the ways in which religious cultures handle information and this involves both the interpretation of texts by individuals - usually charismatic leaders of religious communities - as well as the discourse produced between the leaders and their followers.

In analyzing the CM, both parts of the interpretive process-individual and group - are needed because they coexist simultaneously. The result of this dynamic interplay causes a message to emerge in the minds of those who engage in the CM's interpretive schema. It is not surprising that Fairclough and Gadamer have both identified the dynamic and interdependent characteristics of information processing. Fairclough refers to a "network of mental representations."161 Gadamer speaks of the interpretive process as that "which is constantly revised in terms of what emerges as he penetrates into the meaning." "162 Both scholars add to the validity of Taylor's method of using the common features of information systems to explain aspects of religious culture. Below, I

\footnotetext{
${ }^{161}$ Fairclough, Language and Power, 132,

${ }^{162}$ Gadamer, Truth and Method, 269.
} 
will seek to show how these scholars explain the interactive and dynamic nature of the interpretive and discursive processes at the CM.

Interpretation and language, being processes of thought, may be analyzed as complex adaptive networks. Fairclough and Gadamer have described remarkably similar dynamics when referring to language and hermeneutics while not necessarily using the technical terminology from information theory. Fairclough describes the dialectical nature of structures and practices in discourse. I find his description of this essentially creative process to be quite similar to the dynamics of CANs. He explains:

Whenever people produce or interpret discourse, they necessarily draw upon orders of discourse and other aspects of social structure, internalized in their MR [members' resources], in order to do so. Through being drawn upon, these structures are constantly being created anew in discourse and practice generally. Discourse, and practice in general, in this sense are both products of structures and the producers of structures. ${ }^{163}$

Fairclough's description of production and interpretation match the essential features of information theory as described by Taylor. CANs are essentially symbolic networks of informational exchange. Information theory is discursive at the most fundamental level. Taylor explains, "that languages more closely resemble emergent self-organizing systems." 164 The common feature here is that discourse may be described as "both products of structures and producers of structures."165

This is a suitable point to bring in one of Gadamer's important contributions to hermeneutics. In Truth and Method, Gadamer explains one of Heidegger's terms- “"forstructure" or the process of projecting meaning onto things - and its implications for the interpretive process. "Working out this fore-projection, which is constantly revised in

\footnotetext{
${ }^{163}$ Fairclough, Language and Power, 32.

${ }_{164}$ Taylor, The Moment of Complexity, 215.

${ }^{165}$ Fairclough, Language and Power, 32.
} 
terms of what emerges as he penetrates into the meaning, is understanding what is there." 166 I would emphasize which is "constantly revised in terms of what emerges."167 This is nearly the same as Taylor's definition of "emergent creativity"- "Never fixed or secure, the mobile site of complexity is always momentary and the marginal moment of emergence is inevitably complex."

Fairclough and Gadamer's descriptions of language and interpretation share two important features with Taylor's descriptions of CANs: 1) The process of interpretation is two-sided as meaning emerges from a text and is also projected onto the text by the subject. 2) The process of interpretation is always emergent and dynamic. As such, discourse itself may be understood as a complex adaptive network because it is always open to new directions, insights, nuances and the like. For example, no two conversations are ever exactly alike and there is no way to predict what a new conversation will produce because meaning emerges as a conversation takes place.

The CM is a complex adaptive network of symbols, myths, and rituals. ${ }^{169}$ Discourse functions on multiple levels between visitors and the sights, sounds, texts, and symbolic imagery that they encounter. Screening information occurs on multiple levels at the museum. Screening happens both consciously and unconsciously, by official CM staff and by the visitors. New information (or data/noise) is always a threat to a closed and pre-established doctrinal position. Reading and interpreting the Bible is not the primary focus at the CM. Rather, certain specific doctrines (such as biblical inerrancy, anti-evolution, original sin, patriarchal ordering of society, etc.) are taken as granted or

\footnotetext{
${ }^{166}$ Gadamer, Truth and Method, 269.

${ }^{167}$ Ibid., [emphasis mine].

168 Taylor, The Moment of Complexity, 23-4.

169 This definition is based on Taylor, After God, 12.
} 
they are seen as essential to a particular conservative tradition's identitiy. Therefore, information which visitors might encounter as a challenge to the YEC point of viewsomething that they have picked up in the media or other sources - must be reshaped in an apologetic way. Taylor explains this dynamic:

Since information is constituted by what it excludes, it inevitably harbors traces of noise. Noise, we have noted, is always in-formation in at least two ways. First, noise is always forming into information and being formed by the processes of exclusion from information as a haunting specter. ... screening simultaneously filters noise and displays information by channeling it into the patterns that eventually constitute knowledge. ${ }^{170}$

I continue to identify remnant traces of noise in multiple exhibits in the museum.

Inevitably, a certain dissonance occurs at some point and the logic of the narrative breaks down. I have written an essay on one such occurrence of the exclusion of information to which Taylor alludes. ${ }^{171}$ Additionally, while some information is screened out, other creative information — not in the original text - is supplied. This can lead to the production of fictions as illustrated below.

An account like Genesis 3-the fall of humanity in Eden - contains elements of myth and/or archetypal features such as a talking snake, a primogenitor couple (Adam and Eve), forbidden fruit, etc. In the main exhibit of the CM (Corruption), a literal and historical presentation of Genesis 3 contains Eve, Adam, the talking snake and the Tree of the Knowledge of Good and Evil. In an effort to make the account actual history, traces of excluded noise/data appear in the ironic outcome of what is produced. In this case, a snake is made to appear as some exotic species that no one has ever seen. As

\footnotetext{
${ }^{170}$ Taylor, The Moment of Complexity, 203-4.

${ }^{171}$ Steve Watkins, "Dragon Snakes and Fictitious Grapes: What Happens When Myths are Literalized," The Fourth R: An Advocate for Religious Literacy 26 (March-April 2013): 6-8.
} 
pictured in Photo 1 (below) the serpent's head is dragon-shaped because of a difficult interpretation of a particular verse. ${ }^{172}$

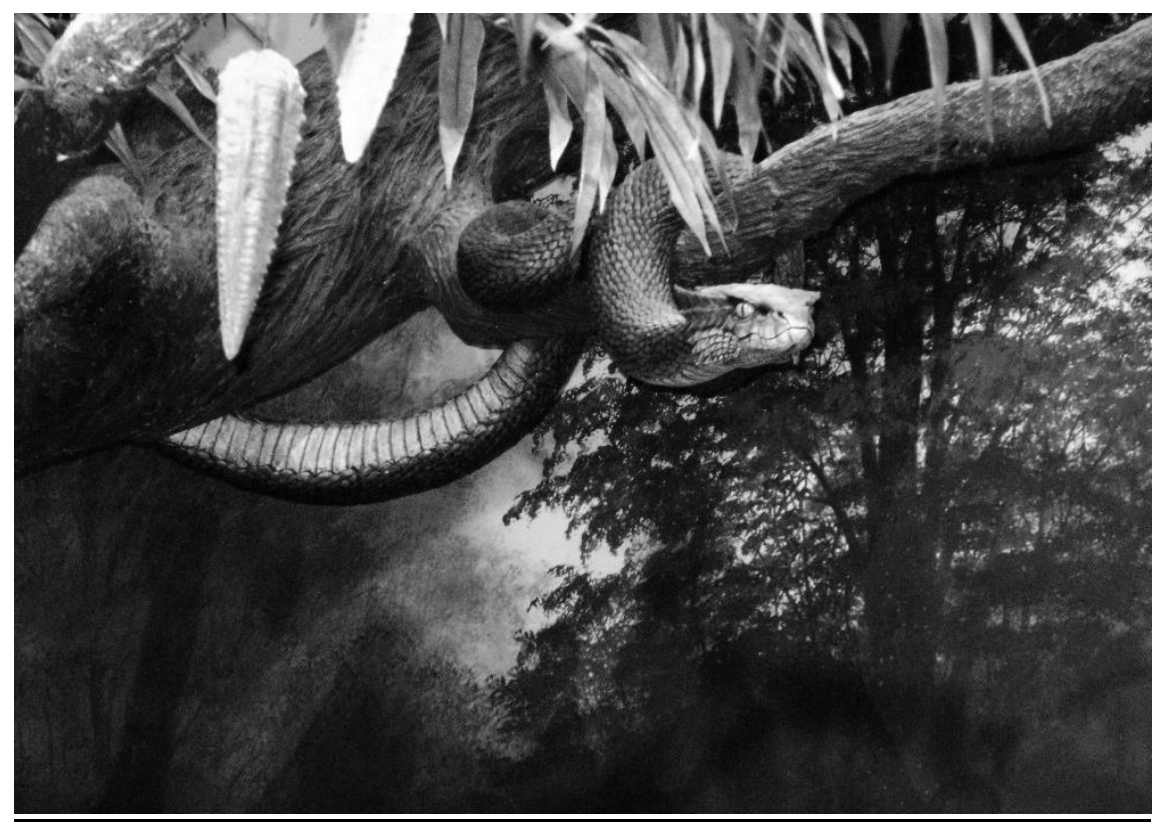

Photo 1. The dragon headed snake that represents the serpent from Genesis 3. Photo: S. Watkins.

In similar fashion, the forbidden fruit of which Eve and Adam ate is represented as something like grapes. However, they are not grapes but rather something that looks exactly like grapes but which grows in a conical shaped pod and on the Tree of the Knowledge of Good and Evil—-this tree too, is not a known botanical species but a fictitious one.

${ }^{172}$ The following paragraph explains the interpretive problem in more detail and is taken from The Fourth $R$ article mentioned above: "The Creation Museum assumes that the 'serpent' - simply an older English synonym for 'snake'-mentioned in Genesis 3 is something other than a normal serpent. The reason for this speculation derives from an obscure verse in which God addresses and curses the serpent: 'Because you have done this, cursed are you among all animals and among all creatures; upon your belly you shall go, and dust you shall eat all the days of your life' (Genesis 3:14 NRSV). Literalizing the verse creates questions that do not arise when it is read as part of a myth. The assumption is that the serpent underwent some transformation from a walking creature to a slithering, snake-like type of animal. But this only makes interpretation more difficult. The Creation Museum makes no comment on snakes literally 'eating dust.' On the other hand, since it is not a real snake, maybe it did eat dust." Watkins, "Dragon Snakes and Fictitious Grapes," The Fourth R: 7. 
An attempt at literalizing an ancient myth requires another form of mythmaking in the form of fanciful snakes and fictitious grapes. The actual representation of these two objects is the trace of the screened noise/data that has transpired. The amount of data/noise that has been screened is quite substantial . Here it amounts to critical studies of mythology, parallel ANE creation literature, ANE cosmology, and other areas of critical biblical scholarship. Taylor identifies this effort to stabilize myth:

In the case of myths, noise is generated by experiences that cannot be adequately processed and by conflicts between and among different symbols and myths. There are three possible responses to such noise: myths can be reinforced, transformed, or destroyed. The most conservative response to apparently discrepant experiences is to try to explain them through the accepted myth by providing reasons and explanations, which are not immediately obvious. When successful, this response serves to reinforce the stability of the myth. The fewer the alternative points of view, the more stable particular patterns of explanation tend to remain. ${ }^{173}$

I find Taylor's observations to be remarkably applicable to the efforts of preserving myth at the CM. Of course, the CM would deny that any part of Genesis is a myth. But these "explanations, which are not immediately obvious," are exactly what the CM has done so effectively for their audience. Also, I intend to demonstrate in Chapters IV, V, and VI that the most effective screen that occurs is the supressing of "alternative points of view," to use Taylor's words.

Screening is complex and it takes place on various levels at the CM. But the main goal at the museum is to stabilize and to create stasis. In the words of James Moore, an effort is made to provide "a cosmos rather than chaos." ${ }^{174}$ The ironic and interesting fact is that because the $\mathrm{CM}$ is itself a CAN, it can never achieve total stability as outside

${ }^{173}$ Taylor, The Moment of Complexity, 212-13.

${ }^{174}$ James Moore, "The Creationist Cosmos of Protestant Fundamentalism," in Fundamentalisms and Society: Reclaiming the Sciences, the Family and Education, eds. Martin Marty and R. Scott Appleby (Chicago: The University of Chicago Press, 1993), 52. 
noise/data are always bombarding the existing structures. ${ }^{175}$ New data/noise from the outside world — mostly the internet and other media — constantly challenge the message of the CM. Screened information from the inside also leads to contradictions in the message as well. These contradictions are not always immediately obvious, but I will document several examples in the three following chapters.

One of these contradictory messages appears on a placard in the Biblical Authority exhibit. The heading, written in large, bold letters reads: "God's Word has triumphed against every attack." Yet, in the next room, Culture in Crisis, the assertion is made that the culture is in crisis because the authority of the Bible is undermined by both the secular world and Christians who accept evolution. In the words of Ham, "[T]hey [Christians who accept evolution] are undermining the very Word of God itself. And this undermining is the issue; this is why we have lost biblical authority in the culture." ${ }^{\prime 16}$ The irony surfaces when one thinks critically about the assertion given in the Biblical Authority room-“God's Word has triumphed against every attack." The implication is that the Bible — understood to be supernaturally preserved and protected — cannot ever be destroyed or undermined. But the message is also that the Bible is under an unprecedented attack that seeks to devalue all of the "Christian" morality of North American society. A basic theological clash occurs at the core of the fundamentalist understanding of God/self/world. The reason for this collision is that Christian fundamentalists are dualists. As such, God is transcendent and all-powerful and yet, humans have an important role to play. Why else would there be so many cultural and

${ }^{175}$ This influx of new data/noise takes place most frequently through the internet. A recent example occurred when Bill Nye posted a short clip on Youtube, criticizing creationist views as antiintellectual. The CM and AIG staff worked round the clock to post three responses to Nye. See one of the responses at: http://www.youtube.com/watch?v=JxX11c1cSWU .

${ }^{176}$ Ken Ham, The Lie rev. ed. (Green Forest, AR: Master Books, 2012), 140. 
religious “calls to arms?" So the world is seen as in God's total control, but also, the world is out of control. I intend to explore this paradox as it arises throughout the CM as noise/data is screened in various ways - textually, discursively, and symbolically.

Chapters III (Selective and Literal Interpretation), IV (Causes and Solutions for Evil), and V (Science Redefined) delve into the major premises of the CM and the theorists discussed in this chapter will be applied as they pertain to specific subjects under investigation. The schema of God/self/world by CM advocates consists of a transcendent God, a sinful yet redeemable self, and a fallen and deceptive world. The CM attempts to provide its adherents with an absolute epistemological structure that will guarantee the good triumphing over the evil. Given this schema, Taylor accurately describes a pattern that fits the CM: "For those with eyes to see, everything becomes a sign referring to a transcendent referent, which secures the foundation of knowledge and basis of action. In an alternative idiom, if one knows the algorithms God prescribes, it is possible to decode the program of both personal and cosmic history."177 This dualistic understanding of God/self/world is one part of what qualifies the CM as a fundamentalist institution.

In the conclusion of this dissertation, I will suggest that the increase of information in today's world actually provides the conditions for rising fundamentalisms. Taylor comments that, "Religious reactionaries provide the clearest example of the religiosity that absolutizes the relative by reifying or fetishizing a particular version of an emergent complex symbolic network."178 This can only occur through a leader who is creative in connecting circumstances in the larger world with a particular slant that makes

\footnotetext{
177 Taylor, After God, 39-40.

178 Ibid., 26.
} 
sense to the followers. If he can do so by making it sound "biblical," then true believers are sure to follow. Here is one example of what Fairclough refers to as producing "coherence." 


\section{CHAPTER III}

\section{THE CONSTRUCTED NARRATIVE: THE EPISTEMOLOGICAL BASE AND A MODERN INTERPRETIVE HORIZON}

The CM has delivered a narrative that offers true believers absolute certainty concerning the origin of the universe. The aim of this chapter is an analysis of the constructed narrative at the CM. The chapter is divided into two main parts: the epistemological base and the modern interpretive horizon. These two components are the most important premises for the explanations that seek to explain corruption in the world and to redefine science - the subjects of Chapters V and VI.

At the most fundamental level, the CM presents an epistemological structure that is indubitably reliable. The opening section of this chapter will demonstrate how an epistemological argument is set forth as one travels through the main exhibits. I will describe the constructed narrative as it unfolds for a typical visitor walking through the main exhibits. As one travels through the structured pathway, certain premises are presented for consideration.

It is only after traveling through approximately one-third of the entire exhibit that the visitor is shown the actual interpretation of the early chapters of Genesis. The selectively literal interpretation of Genesis 1-11 is primarily limited to four exhibitsCreation, Corruption, Catastrophe, and Confusion. Thus, my approach will deal first with 
the epistemological premises, especially as they have bearing on how one interprets the biblical texts.

The second section of this chapter will deal with the actual hermeneutic approach used by advocates of the CM. Using the metaphor of a fused-horizon, Gadamer's hermeneutic insights will be applied to this type of hermeneutic practice. The fused horizon will be analyzed as it in the Creation and Corruption exhibits specifically.

\section{The Epistemological Base}

I begin with the CM's epistemological structure for two reasons. First, as the visitor enters the main exhibit, the initial two rooms are devoted to teaching this premise. Second, the epistemological dichotomy provided is the most important foundational premise in the museum. As explained below, the commitment to a guaranteed source of perfect knowledge supersedes every other competing source of knowledge. Once this epistemological structure is established, the constructed biblical narrative is presented as the only interpretation of the Bible that produces certainty.

The first room is called Slot Canyon. Slot Canyon is made to look like a section of Arizona's Grand Canyon. In this exhibit, a video screen loops a short presentation that offers an alternative explanation as to how the Grand Canyon was formed. The small exhibit contains two windows, each showing a photo of a canyon: on the left is the Grand Canyon and on the right, is a similar looking canyon formed after the Mount St. Helen's eruption. The visitor stands in the middle of these two expansive shots as they look at and listen to the video being played. The visitor is positioned to compare the similarities of these two canyons while listening to the narrator explain how canyons may be formed by 
rapid, catastrophic events - such as the formation of some smaller canyons during the Mount St. Helen's eruption. The video screen, located in the middle of the two canyon photos, begins with the question appearing on the screen and read by the narrator: "Have you ever wondered where canyons come from?" The following audio narration follows as transcribed below:

It is commonly taught that canyons are formed by rivers over a very long time. We know that mud flows from the crater of Mount St. Helens carved this canyon out of soft rocks in only hours. And this canyon out of solid rock, in less than four years. So how are canyons really formed? ${ }^{179}$

Since the Grand Canyon has been used as a great visual example of vast geologic columns by evolutionists, the CM seeks to reinterpret this data by suggesting a radically different way to interpret geologic data. The film uses the Mount St. Helen's eruption in 1980 to provide evidence that canyons could form rapidly through various catastrophic events such as volcanoes, earthquakes, and floods. The video draws the viewer in with the question concerning how canyons are formed. The alternative explanation is subtly asserted with data from observations that sound scientific. The photos that appear in the video and in the window labeled "Mt. St. Helens Observation Station" look similar to pictures from the Grand Canyon.

Slot Canyon is the first exhibit that begins by setting two methodologies side-byside - the scientific consensus and the biblical narrative. ${ }^{180}$ This dichotomy is clearly explained in an adjacent display (Starting Points), but in this initial exhibit the beginning of the epistemological approach is established. The scientific consensus is challenged on

\footnotetext{
${ }^{179}$ The video narration was transcribed from a digital recording in the Slot Canyon exhibit on July 15, 2013 at the Creation Museum, Petersburg, Kentucky.

${ }^{180}$ By "biblical narrative" I mean the selective interpretation at the CM which will be discussed at length later in the chapter. In Slot Canyon, Noah's flood is used as an alternative explanation for how canyons may have formed.
} 
the grounds that there are other explanations for how canyons may have formed, including rapid, catastrophic events such as Mt. St. Helen. The visitor is not given the option of looking in any depth to scientific perspectives on geology and the age of the earth-especially the many recent rebuttals to YEC that the scientific community has provided. ${ }^{181}$ Most of the information presented is a YEC apology that seeks to replace the scientific consensus.

The visitor assumes the role of a judge of the scientific theories on earth history. As Ella Butler notes: "[Visitors] place themselves in the scientist's shoes to consider the gap between evidence and explanation." "182 The role or script of "lay interpreter" will be demonstrated at various different exhibits. Placing the visitor in this interpretive mindset is important because it provides a sense of "ownership" to the conclusions accumulated throughout the museum. The visitor is led to feel empowered by the ability to critique scientific ideas and to replace them with more spiritual and divinely sanctioned alternatives. Slot Canyon is the first place that frames the dialogue of examining scientific specimens as one normally would in any other museum of natural history or anthropology — with the exception of the revisionist and anti-evolutionary claims.

The next exhibit, Dig Site, is a mock-up of a fossil dig in which two mannequins, fashioned as paleontologists are positioned as if in the act of uncovering a Utahraptor fossil. One of the paleontologists is said to be a creationist and the other an evolutionist. A CM source explains the difference between the two: "Two scientists, one a creationist,

${ }^{181}$ The following sources are some of the recent scientific responses to the problems involved with YEC in general and with flood geology and catastrophism in particular: David Montgomery, The Rocks Don't Lie: A Geologist Investigates Noah's Flood; Mark Isaacs, The Counter-Creationism Handbook; Eugenie C. Scott, Evolution vs. Creationism; Karl W. Giberson, Saving Darwin; and Denis O. Lamoureux, Evolutionary Creation.

182 Ella Butler, "God is in the Data: Epistemologies of Knowledge at the Creation Museum." Ethnos 75 (September 2010): 240. 
one an evolutionist with two different interpretations of the history of this dinosaur skeleton. Why?"183

Here is an important example of a major premise that is reinforced throughout the $\mathrm{CM}$. That premise is that two equally credentialed archeologists are looking at the same facts (the fossil evidence), but because they have different underlying assumptions they reach two widely divergent conclusions about the fossil. What is not stated in the CM is that YEC's would not likely be put in charge of a university sponsored archaeological dig for the same reason that they are not able to publish in academic journals on paleontology. Further, the explicit assertion that emerges, as we shall see later in the Starting Points exhibit, is that the YEC interpretation is on the side of God and the evolutionist's interpretation is jaded by secular humanistic, and hence godless, assumptions based on a corrupted epistemology. There is no middle ground for Christians who are also evolutionists.

A current hypothesis is that this dichotomy is one of the reasons that many fundamentalists and evangelicals adopt the YEC view. They simply do not want to align with what they perceive as the corruptions of a secular humanistic worldview. All of the other Christian positions on evolution, of which there are several, are absent from the materials in the main exhibits. Thus, polarization occurs between the right and godly position versus the wrong, evil, and atheistic position. ${ }^{184}$

${ }^{183}$ Answers in Genesis, Journey Through the Creation Museum: Prepare to Believe (Green Forest, AR: Master Books, 2008), 22.

${ }^{184}$ Screening of information has already occurred. Information regarding other pro-evolutionary interpretations of Genesis, the facts about the reality of YEC paleontologists not being put in charge of an archeological dig, and the immense difference in scale between Mount St. Helen's canyons and the Grand Canyon are examples of this screening process. 
The Dig Site also contains a placard that lays out the logic that the CM uses to attack the scientific consensus. The Placard reads: ${ }^{185}$

The evidence is in the PRESENT.

Archaeopteryx Fossils

This is a cast of an Archaeotperyx lithographica specimen from the Solnhofen Limestone (Jurassic System), Germany.

But what happened in the PAST?

- When did the animal live?

- What did the animal look like?

(For example, was it a bird?)

- How did it behave? (For example, did it fly?)

- How was the animal related to other animals? (For example, is it related to dinosaurs?)

Placard 1. Located in the Dig Site. Transcribed from photograph: S. Watkins.

Through a series of questions about what happened in the past - a time and place that lacks any written history - the CM inserts doubt that there can be any scientific certainty about the interpretation of the fossil evidence. This is a subtle, yet ingenious part of the CM's argument. Science is actually open to revision of current theory. This is one of the most basic, yet important, features of the scientific method. Scientists are always discovering new aspects of existing theories or replacing outdated theories with better ones. Sometimes, an entire theory is called into question, at other times a particular theory is able to be more accurately revised. But for a lay person not trained in science,

185 The placard has been transcribed from a personal photo of the display board. The display board is located in the Dig Site. I will pick up the attack on the definition of science in considerable depth in Chapter VI. Here I mention it because of how it becomes embedded in the epistemological strategy developed in the beginning exhibits. 
the thought that these are only fossils which are subject to a vast range of interpretations sounds plausible. A major contribution of Butler's article is that she demonstrates how the CM presents the Bible as a fact, just like a fossil. But the Bible is said to be even more reliable than a mere physical fact (like a fossil). Butler's articulation of this strategy is impressive:

With this separation of fact and interpretation, we see another layer of meaning when the Bible is placed in the display case, and thus likened to the fossil. The display case serves to mark the boundary between fact and interpretation: inside is the realm of the 'fact', outside is its interpretive counterpart. ${ }^{186}$

Further illustrating this "doubt versus fact" premise, another placard located on a wall of the Dig Site exhibit portrays the major difference in interpreting fossils (see Placard 2, below). The two ways of interpreting any data are from man's point of view and from God's point of view. Here the schema of God/self/world is an important part of the CM's informing theology. ${ }^{187}$ The effects of the Fall have caused a twofold problem for human interpretation. First, humans that are unregenerate - and thus without the Holy Spirit — are jaded by sin and tend to always draw the wrong inferences from any so-called fact. Second, the pre-Fall world is assumed to be radically different—physically speaking - than the present world. ${ }^{188}$ The placard in the Dig Site describes the epistemological dichotomy as it refers to the paleontologists: ${ }^{189}$

${ }^{186}$ Butler, "God is in the Data," 247.

${ }^{187}$ I will deal with the schema of God/self/world in more detail in Chapter V, "Evil Explained."

${ }^{188}$ For example, the CM assumes the literal account of people living nearly one thousand yearssuch as Methuselah, Noah, Adam and the list of others in Genesis 5. They also suppose that there was no death, no predatory animals, and no disease of any kind. Such assumptions make it extremely difficult to apply the same scientific measures of the current, physical world. In fact, aside from a few hints in Genesis $1-3$, most of these pre-fall ideas are extrapolations based on theological assumptions.

${ }^{189}$ The placard has been transcribed from a personal photo of the display board. The display board is located in the Dig Site. 


\begin{tabular}{|c|c|}
\hline starting with & starting with \\
\hline MAN'S WORD & GOD’S WORD \\
\hline $\begin{array}{l}\text { The Utahraptor lived in the } \\
\text { Early Cretaceous world about } 125\end{array}$ & $\begin{array}{l}\text { The Utahraptor lived in the pre-Flood } \\
\text { world about } 4,300 \text { years ago }\end{array}$ \\
\hline evolved through millions of years & $\begin{array}{l}\text { God made the beasts of the earth } \\
\text { (Genesis 1:25) }\end{array}$ \\
\hline Caught in a flooding river & Caught in the Great Flood \\
\hline died in the normal course of events & $\begin{array}{l}\text { And the Lord said, "I will destroy man } \\
\text { And beast..., for I repent that I made } \\
\text { them." } \\
\text { (Genesis 6:7) }\end{array}$ \\
\hline Died out on a river bank & Died on Flood waters \\
\hline dried out in the sun & $\begin{array}{l}\text { And all flesh died that moved upon the } \\
\text { earth. } \\
\text { (Genesis 7:21) }\end{array}$ \\
\hline Slowly buried by river sediments & Suddenly buried in the Global Flood \\
\hline Slowly buried and gradually fossilized & $\begin{array}{l}\text { The world that was then, being overflowed } \\
\text { with water, perished. ( } 2 \text { Peter } 3: 6)\end{array}$ \\
\hline Exposed in the present & Exposed in the present \\
\hline
\end{tabular}

Placard 2. Located in the Dig Site. Transcribed from photograph: S. Watkins.

The placard illustrates the two epistemological methods advertised at the CM. This "God versus man" dichotomy is repeated so often throughout the museum that it becomes a kind of mantra that appears in all of the teaching points in the exhibits. Almost always, the CM viewpoint is supplemented with Bible verses to support their claim. Additionally, the CM has effectively separated the physical facts from a more important philosophy of material matter. Butler describes this phenomenon: "The point is that it [the dichotomous idea conveyed in the display boards] inserts a gap between the material 
data and the scientists who view them." 190 This approach is demonstrated most clearly in the following room, Starting Points.

Continuing on from the Dig Site, the museum's main argument is articulated and reinforced in Starting Points. This room may be the most important room in the museum given the epistemological choices it offers. In effect, Starting Points is a strategic effort to get an intellectual commitment to the CM's premises. The visitor has already been exposed to the epistemological technique of comparing two competing models in Slot Canyon and the Dig Site. But Starting Points is a simple yet philosophically astute argument. For example, it questions the presuppositions and flaws of scientific models as a whole. ${ }^{191}$ Chapter VI will deal with this line of reasoning as it pertains to a critique of science. The important emphasis in Starting Points is on the constantly changing nature of scientific knowledge. The CM's goal is to establish that scientists are fallible and thus science is an uncertain enterprise. So as an epistemological source, science fails to be a source of knowledge that can deliver the kind of indubitable certainty that the CM espouses. Evolution becomes the culprit and example of science's "great mistakes." On the other hand, God's word (the Bible) is offered as a perfect and flawless record of history. ${ }^{192}$

The purpose of Starting Points is explained in an official CM publication:

Starting Points Room: Ultimately, to understand the origin of life and the universe, there are only two possible places to start: (a) the Word of the One Who has always been there and knows everything (the Creator God of the Bible) or (b) autonomous human reason (man's beliefs). Based on these two starting points,

${ }^{190}$ Butler, "God is in the Data," 245.

${ }^{191}$ Ronald Numbers was the first to identify this approach as Kuhnian, The Creationists: The Evolution of Scientific Creationism (Berkeley, CA: University of California Press, 1992), 246-7. Butler also makes this connection as referenced in Footnote 25 (above).

${ }^{192}$ This view of the Bible as perfect and flawless is one of the central tenets of fundamentalism. Also called "Biblical inerrancy," the CM's logic falls apart if this premise is rejected. 
there are different interpretations of the same evidence. The different starting points explain why the different views about origins are in conflict - because there are two totally different worldviews. ${ }^{193}$

This provision of two extreme options — God's view and man's view — attempts to force the visitor to align with the CM's point of view. Evolutionary science is cast in an extremely negative light in numerous places in the museum. The CM effectively channels the visitor into alignment with one of two positions. The first position situates a person as redeemed, as are all young earth creationists. The only other option is that of the unredeemed, the position of evolutionists, secularists, and people of other world religions. A visitor is forced to choose sides. Neutrality is never an option in the dualist world. What follows throughout the museum is an alignment of evil and corruption with evolution and science in contrast to goodness and God on the side of young earth creationism. Having a starting point of certainty is said to be crucial, not only for understanding the history of the world, but also for maintaining an orderly and morally upright society. What follows is a visual and auditory warning of what happens to the world when people diverge from a literal reading of the Bible. By aligning moral and physical evil with the theory of evolution, the visitor is guided toward the inescapable conclusion that the CM is on the side of God and good.

Starting Points has a well-lit and uplifting feel to it. The walls are off-white and the floor is an attractive, sophisticated looking hardwood. One can hear the sound of gentle and soothing acoustic guitar music playing on the sound system. The sound of the music is similar to the lead-in theme to the Master's golf tournament on CBS. One adjective I might use to describe the room is "contemplative." In Slot Canyon and the Dig Site, audio and video clips are constantly playing. Starting Points has no audio narration.

${ }^{193}$ Journey Through the Creation Museum, 27. 
The gentle, background music creates a pensive, low-key atmosphere. The main purpose of Starting Points is to guide the visitor to the conclusion that only the Bible is the way to certainty. Since the world is corrupt and people are corrupt, only the enlightened word of God can be taken as the source of truth. This is so because only God is uncorrupted.

Starting Points contains ten large display boards that explain the only two options for interpreting the past - especially the origin of the universe and life. The point is that the facts of the present world are all the same. Like the two paleontologists in the previous room, one a creationist and the other an evolutionist, the fossils are the same.

The key lies in what starting assumptions one uses to interpret the physical data.

Autonomous human reason is said to be untrustworthy because it is "arbitrary." The first large display board in Starting Points explains the importance of this concept.

Broadly speaking, "man's word" refers to "autonomous reasoning"- the idea that the human mind can determine truth independently from God's revealed truth, the Bible. Reasoning is God's gift to humankind, but $\mathrm{He}$ has instructed us to use the Bible as our ultimate starting point (Proverbs $1: 7)$ and also to reject speculations that contradict God's knowledge (2 Corinthians 10:5).

Philosophies and world religions that use human guesses rather than God's Word as a starting point are prone to misinterpret the facts around them because their starting point is arbitrary.

Every person must make a choice. Individuals must choose God's Word as the starting point for all their reasoning, or start with their own arbitrary philosophy as the starting point for evaluating everything around them, including how they view the Bible

Placard 3. Located in Starting Points. Transcribed from personal photo: S. Watkins.

The important exhortation is the establishment of the Bible as the only reliable "starting point" for "all their reasoning." Proverbs 1:7 is cited as proof that "[God] has 
instructed us to use the Bible as our ultimate starting point." ${ }^{, 194}$ On the other hand, "autonomous reasoning" is targeted as any epistemological approach other than that of using the Bible as the guiding source for all fields of inquiry. The second verse, 2 Corinthians 10:5, is referenced as instruction to "reject speculations that contradict God's knowledge."195 While it would require considerable space to survey the variety of interpretations of these two verses, I would point out a couple of observations. The CM statement places the emphasis on using the Bible as a starting point. However, in both verses cited in the display board, there is no direct reference to the Bible as a canonical collection. ${ }^{196}$ Further, it is anachronistic to assume the ancient writer of Proverbs and the first century writer of 2 Corinthians (the apostle Paul) would have had any notion of the Bible as canonical in the twenty-first century, evangelical sense. Nor is there any explicit directive for the use of such a canonical collection of texts as an epistemological approach to modern science.

Even if one assumes that there is some biblical instruction to "use the Bible as our ultimate starting point," it remains unclear how one actually accomplishes such a task. For example, how would a chemist working on advanced polymers use the Bible as a starting point? Research is done in laboratories each day without any biblical influence-

\footnotetext{
${ }^{194}$ Proverbs 1:7 reads as follows: "The fear of the LORD is the beginning of knowledge; fools despise wisdom and instruction" (New Revised Standard Version). Here, I would only note the absence of any directive to use the Bible as a starting point. As noted by Robert Alter, this verse is simply "a distinctive Israelite emphasis not given in analogous Wisdom texts in Egypt and Mesopotamia." The main reason for Alter's assertion is the distinctive Israelite use of Yahweh, noted by the word LORD in all capital letters - a common convention in modern translation. The Wisdom Books: Job, Proverbs, and Ecclesiastes (New York: W.W. Norton and Company, 2010), 194.

${ }^{195} 2$ Corinthians 10:4b-5 reads as follows: "We destroy arguments and every proud obstacle raised up against the knowledge of God, and we take every thought captive to obey Christ" (New Revised Standard Version).

196 The standard dates for the acceptance of the Hebrew and Christian canons are as follows: The Hebrew scriptures developed canonical status at the synod of Jabneh (Jamnia) at the very end of the first century CE. The New Testament writings developed canonical status in the fourth and fifth centuries (CE) - beginning with Athanasius of Alexandria's list of the twenty-seven inspired books from Matthew to Revelation in 367 CE.
} 
whatever that may be. The statement that "[i]ndividuals must choose God's Word as the starting point for all their reasoning" is hard to even quantify [emphasis mine].

On the other hand "man's word," as opposed to "God's word," is said to be "autonomous reasoning - the idea that the human mind can determine truth independently from God's revealed truth, the Bible." Part of the difficulty involves what is meant by the term "truth." Conceptualizing the validity of this proposition is quite difficult. For example, I cannot understand how Chinese mathematical developments from the first century—formulations of mathematical "truth" - could have been using the Christian Bible as a starting point. The implication is that the Chinese would end up with faulty math in such an instance, if all truth depended upon the Hebrew and Christian scriptures. The following quotation, asserted in Placard 3 (above), is an example of this inconsistent reasoning:

Philosophies and world religions that use human guesses rather than God's Word as a starting point are prone to misinterpret the facts around them because their starting point is arbitrary.

If such a statement was accurate, I fail to see how scientific knowledge could advance with the prestige and accuracy that it has attained.

In any case, the Starting Points exhibit serves as a warning to visitors that the Bible is the only epistemological source that will guarantee absolute truth. As the display board explains, "Every person must make a choice." This room is also an invitation to follow the world of the redeemed and enlightened, as opposed to the darkened speculations of anyone who does not share the correct starting point. But I find this to be an ingenious strategy at this point in the museum. Christian visitors (mostly evangelicals and fundamentalists) will obviously side with "God's word" as it is framed in this 
fashion. Once the commitment to the Bible is made, the rest of the museum exhibits expand on that commitment. The museum narrates the only valid interpretation of Genesis 1 to 11 . Selectively literal interpretation emerges through a subtle screening out of all conflicting interpretations of Genesis 1-11. It is to this subject of the constructed biblical narrative that I now turn.

\section{The Modern Interpretive Horizon}

\section{Inerrancy}

Before I offer the interpretation of Genesis 1, as presented at the CM, it is important to sketch the major theological and hermeneutic premise that requires such a selective and literal reading of Genesis. ${ }^{197}$ As has been mentioned above, the doctrine of biblical inerrancy is vital for YECs. While there is a relatively wide range of positions on inerrancy, especially in evangelicalism, the CM sticks to the typical fundamentalist extreme. Ken Ham writes: "After all, the entire Bible is inspired and inerrant, and no book is less important than others. $" 198$ The official Answers in Genesis website includes the following paragraph in its Statement of Faith:

The 66 books of the Bible are the written Word of God. The Bible is divinely inspired and inerrant throughout. Its assertions are factually true in all the original autographs. It is the supreme authority in everything it teaches. Its authority is not limited to spiritual, religious, or redemptive themes but includes its assertions in such fields as history and science. ${ }^{199}$

${ }^{197}$ The issue of inerrancy is the single most important reason that I identify the CM as a form of fundamentalism. In the concluding chapter of the dissertation, I will expand upon this assertion.

${ }^{198}$ Ken Ham and Bodie Hodge eds. Begin: A Journey Through Scriptures for Seekers and New Believers (Green Forest, AR, 2011), 8.

${ }^{199}$ The citation above is listed as the first bullet in Section 2: Basics, under The AiG Statement of Faith. Answers in Genesis, http://www.answersingenesis.org/about/faith accessed July 19, 2013. 
The last part of this statement is revealing. It sets the Bible apart as an historical and scientific source of information that are also said to be without any error. The inclusion of science as an area where the Bible speaks authoritatively is problematic. As an aside, this is also a point of departure from many evangelicals who hold to some form of inerrancy. ${ }^{200}$ In fact many conservative positions would stay with spiritual, religious, and redemptive aspects of the Bible as those that are inspired and inerrant. But including science is the most extreme position because it is a relatively recent domain of disciplines. ${ }^{201}$ Pressing the Bible into a flawless historical account is problematic as well. History is a much more difficult subject to unravel because many of the Bible's claims are rooted in actual history - especially beginning with the patriarchal narratives in Genesis 12 . However, my analysis will focus on scientific concordism that occurs because it is the subject on which the CM premises are based.

The strategic use of questions is prevalent in Ham's writings and in the language of the exhibits. Instilling doubt is effective in both challenging science and in presenting inerrancy as the only reliable way to read the Bible. Ham writes, "If God did not mean what He said in Genesis, then how could one trust Him in the rest of the Scriptures?"202 This question causes a serious existential problem for Christians who believe that the Bible is the inerrant word of God. This is the conclusion that ethnographer David Long found in his research on Northern Kentucky University college students. Long writes

${ }^{200}$ There are at least five different views on biblical inerrancy as may be seen in a book due to be released December 10, 2013. J. Merrick and Stephen M. Garrett eds. Five Views on Biblical Inerrancy (Grand Rapids, MI: Zondervan, 2013).

${ }^{201}$ As I have referenced in Chapter III, the Scientific Revolution occurred no earlier than Copernicus - sixteenth century. Further, the overwhelming discoveries in the twentieth and twenty-first centuries have expanded scientific knowledge exponentially. This simple fact should alert any student of the biblical texts as to the problem of imposing scientific statements onto a set of texts that predate modern science by fifteen-hundred years, at a minimum.

${ }^{202}$ Ham, The Lie, 17. 
about the implications for one of his conservative Christian informants: "For evolution to be true, his [Tyson's] interpretation of the Bible is likely untrue. If this is so, his ethical system breaks down-'I don't even know why I should be good. ${ }^{, 203}$ Long documents how conservative Christians are immediately threatened if any part of the Bible is not absolutely accurate. Existential anxiety encroaches on a whole system of faith that includes, the existence of God, ethical and moral absolutes, and the stability of society as a whole.

The idea of biblical inerrancy as the only guarantor of certainty is not a new strategy among fundamentalists. Kathleen Boone has documented this form of argument by conservative Christian apologist Francis Schaeffer as early as $1975 .{ }^{204}$ But Ham has marshaled a convincing attack on evolutionary science by pitting the whole of Christianity (including morality, politics, and salvation) against any view of the Bible that does not maintain inerrancy. The effectiveness of this strategy derives from the fact that conservatives are driven to a point of either/or logic. Either evolution never happened, or the Bible must be discarded as completely irrelevant and untrustworthy. Ham is also quick to assert that the doctrine of inerrancy must be maintained in order to avoid moral relativism. I deal with this issue in the following chapter; however, this is one of the most persuasive arguments set forth by the CM.

${ }^{203}$ David E. Long, Evolution and Religion in American Education: An Ethnography (New York: Springer, 2011), 42.

${ }^{204}$ Kathleen C. Boone, The Bible Tells Them So: The Discourse of Protestant Fundamentalism (London: SCM Press, 1990), 24. 


\section{An Ancient Story in Modern Terms}

Once visitors are committed to the CM's version of the Bible as history, the exhibits lead them through a selectively literal interpretation of the world's history as it occurs in Genesis 1-11. Explaining the world's history as relatively recent (six thousand years ago $)^{205}$ _instead of the conventional scientific models of fourteen billion years for the age of the universe and four to five billion years for the age of the earthaccomplishes the ultimate defeat for evolutionary theory. If people can be convinced that the earth is a mere six thousand years old, then there is no possible way evolution could have occurred. There would simply not be nearly enough time for all of the epochs required for evolutionary change. The problem for YECs is that such a short period of time requires an explanation for the fossil record and the geologic column that looks to be vastly older than the CM espouses. Once someone accepts the CM's explanation as the true word of God, they are locked into maintaining that premise or else being guilty of rejecting God's literal word.

The constructed narrative of history begins in the 6 Day Theater. There are three rooms in between Starting Points and the 6 Day Theater, however, these rooms-Biblical Authority, Graffiti Alley, and Culture in Crisis - will be discussed in Chapter V as they pertain to the causes of modern corruption and evil. After travelling through a dark Time Tunnel, the visitor is situated in a theater to listen to a short film in which the narrator reads the first chapter of Genesis while dramatic images of the earth's creation are shown on the screen. The video is four minutes and fifty-one seconds in duration. Soft, dramatic

${ }^{205}$ Briefly mentioned in Chapter II, the CM arrives at the age of the earth based on Archbishop James Ussher's (1581-1656) calculations. Ussher added together all of the chronologies in the Old and New Testaments and came up with the date of creation at 4004 BC. The CM has reprinted Ussher's book, The Annals of the World, and offers several versions for sale at the CM bookstore-James Ushher, The Annals of the World, rev. Larry and Marion Pierce (Green Forest, AR: Master Books, 2003). 
music is played in the background as the stages of creation appear visually in the order mentioned in Genesis 1.

As the narrator of the film reads the first two verses of Genesis, an image of the earth begins to appear on a black screen. The image is a round, spherical body shrouded in a dark, cloudy covering. The interpretation is that of a modern cosmological view of planet earth as a spherical body. There is no discussion in Genesis 1 of the shape of what is called "earth" (translated from the Hebrew word Erets). While there are some comments about dry land appearing and waters being "gathered," there is no hint as to what the shape of the earth was. In fact, the mass of primordial matter described in the first three verses is said to be undefinable. ${ }^{206}$ Yet, as verse two is read, an image of a spherical earth is portrayed on the screen. Here is the first example that a modern imposition is being made on the text. It is also difficult to imagine how something defined as "without form" could have the form of a sphere.

As the narrator reads that "darkness was on the face of the deep," there is a faint light that shadows the spherical earth. Light is not said to be created until verse three. The picture of earth is quite hard to make out until the third verse is read: "And God said, 'Let there be light,' and there was light." 207 As the narrator reads verse three, a second, brighter light appears behind the spherical earth. Because the sun, moon, and stars are not mentioned until the fourth day (Genesis 1:14-19), the light is not identified as anything we now understand as light-producing - i.e. the stars. Here is an example of how closely

\footnotetext{
${ }^{206}$ Verse two is translated: "The earth was without form and void; and darkness was on the face of the deep. And the Spirit of God was hovering over the face of the waters." This translation, The New king James Version, is the one read in the video. The phrase in Hebrew (tohu vavohu) translated "without form and void" fails to capture the word play in Hebrew. The phrase rhymes in Hebrew and is better translated by Robert Alter as "welter and waste." I prefer to translate the phrase "chaos and chasm" because this phrase picks up the sound of the word play and better transfers the ANE idea of God bringing order to the watery chaos.

${ }^{207}$ New King James Version.
} 
and literally the $\mathrm{CM}$ follows the text of Genesis. One of the first clues to the scientific departure of the CM's explanation is the fact that they must resort to supernatural explanations to explain the light created without the presence of the sun or other stars.

It does not require a significant level of proficiency in science to see the problem of light without a sun or stars. However, Ham denies that there is any problem in the first place. Responding to this issue in an audio recording, he asserts the following: "But really, there's no problem if we simply read Genesis as is. God created light first. He then created the sun to be the light bearer for earth from day four of the creation week onwards." 208 This example shows why serious scientists cannot engage YEC arguments. Ham's assertion is an appeal to a supernatural source of light without the stars. Thus, it is impossible for empirical science to comment on such an argument. This is an example of the so called god-of-the-gaps argument. In essence, when no observable, scientific data can explain an apparent discrepancy in the Bible, an appeal is made to the omnipotence of God as being able to miraculously provide light without any known source.

Another interesting interpretive move is that the spherical earth is presented as rotating on its axis. Without reference to the sun and other planetary bodies, the video shows the backlit planet rotating as the viewer listens to the narrator continue to read the verses. Of note here is that the Genesis text nowhere expresses an idea of the earth rotating in space. The verses are simply read with a modern notion of the cosmos appearing visually for the viewer. The merging of two completely different interpretive horizons appears seamlessly in the video.

208 Transcribed from audio file. Ken Ham, Answers in Genesis. http://www.answersingenesis.org/media/audio/answers-daily/volume-103/light-before-sun (accessed September 30, 2013). 
The reading of the next three verses (Genesis 1:6-8) are the most difficult to conceptualize visually. They also provide one key term (firmament) that should expose the ancient horizon for what it was. The verses read as follows:

Then God said, "Let there be a firmament in the midst of the waters, and let it divide the waters from the waters." Thus God made the firmament, and divided the waters which were under the firmament from the waters which were above the firmament; and it was so. And God called the firmament Heaven. So the evening and the morning were the second day. ${ }^{209}$

The video is a bit vague in identifying what the firmament actually is. ${ }^{210}$ The scene of a vast body of water is shown and as the words "let there be a firmament in the midst of the waters" are read, a curtain of mist rises from the body of water. The scene then zooms out to show the earth as a spherical mass with clouds and water-similar to what satellite photos today would show-minus the land masses. What the firmament is, according to the video, is not easy to define. However, after showing the video and questioning several informants, the answer they gave is that the firmament appears to be something like the atmosphere or clouds. ${ }^{211}$ I will discuss the term "firmament" in great detail in the following section. Here, I am attempting to present this idea as it is portrayed in the video.

Next, the narrator reads verses nine to thirteen. This is the account of the third creation day. The screen shows the spherical earth turning on its axis once again. The major difference this time is the addition of land at the command to "let the dry land

${ }^{209}$ The New King James Version is cited because that is the translation used in the video.

${ }^{210}$ Hermeneutic dissonance even occurs as I try to use verb tenses in the footnoted sentence above. For example, I use "is" instead of "was" because the firmament actually exists for YECs as a present reality. But as I interpret the text, the firmament was something - past tense - in the minds of ancient Near Easterners, but it is not actually a reality for me or my colleagues.

${ }^{211}$ I played the video clip to an anonymous group of seventeen people who had never viewed it previously. The overwhelming consensus was that the images representing the firmament appeared to be something like the atmosphere and/or clouds. I will deal with this concept as a major focus in the following section on the "modern horizon." 
appear." The rotating earth appears very similar to that of actual imagery from outer space. One exception is that the land portions of earth are presented as one supercontinent, or Pangaea. ${ }^{212}$ As verse eleven is read, photographs appear of various plants and fruit to match the command to let the earth bring forth grass, herbs, fruit, and trees. As a reminder, the sun has yet to be created. The pictures of plants growing and producing fruit in the daylight is yet another scientific problem. But this problem is not addressed in the video.

As the fourth day (Genesis 1:14-19) is being read, the earth continues to rotate on its axis. Verse fourteen reads: "Then God said, 'Let there be lights in the firmament of the heavens to divide the day from the night; and let them be for signs and seasons, and for days and years.",213 The video shows the appearance of stars throughout space as the backdrop for planet earth. It is not until verse sixteen is read that the sun and moon appear. As the narrator reads the words "Then God made two great lights: the greater light to rule the day, and the lesser light to rule the night. He made the stars also," the sun appears (the greater light) from the perspective of earth during the day and the moon (the lesser light) appears at night.

On the fifth creation day (Genesis 1:20-23), the scenes contain pictures and actual videos of real birds and fish. The scenes are dramatic as soft music backgrounds the narrator's voice. The fish appear as mostly exotic ocean species such as anemone, whales (technically mammals), a jellyfish, and a school of ocean going fish. The music continues

${ }^{212}$ Also spelled "Pangea," this supercontinent is judged by secular geologists to have broken up around 200 million years ago. According to CM sources, the Panagean supercontinent was broken up by Noah's flood. See Andrew A. Snelling et al., The New Answers Book, vol.1 (Green Forest, AR: Master Books, 2006), 186-97.

${ }^{213}$ New King James Version. 
as the birds appear on the screen - an eagle, a bat (technically a mammal), a heron, and a pair of Mallard ducks.

The final creation day (Genesis 1: 24-31) is similar to the presentation of day five as a series of animal photographs appear as the narrator reads. The animals appear in the following order: a kangaroo, a dinosaur (drawing), a raccoon, a ram, a camel, a horse, a caterpillar, some small striped African mammals (I cannot identify their species), and a butterfly. As the verses of the creation of humanity are read (Genesis 1:28-31), two mannequins of a man and a woman are displayed from a three-hundred and sixty degree pan shot. The mannequins appear to be the same ones displayed in the Garden of Eden exhibit in the CM. The last scene in the video shows a naked man and woman walking arm in arm and looking into a sunset. The scene is hard to identify geographically, but most interesting in this last scene are two dinosaurs just on the left of the screen and not far from the couple presumed to be Adam and Eve.

The Six Days video adds no verbal commentary to the verses being read. The interpretation occurs in the images that appear. On the one hand, this approach has the benefit of presenting a straight-forward and extremely literal interpretation. Almost every verse is easy to visually display. However, a careful analysis of this type of interpretation is actually an example of concordism—reading into an ancient text a set of modern understandings. It is to that subject that I now turn. 


\section{Concordism as the Horizon Fused in Genesis 1}

Hans-Georg Gadamer has provided an essential concept for the interpretation of any text. Quoted in Chapter III, Gadamer's insight warrants a second citation:

A person who is trying to understand a text is always projecting. He projects a meaning for the text as a whole as soon as some initial meaning emerges in the text. Again, the initial meaning emerges only because he is reading the text with particular expectations in regard to a certain meaning. ${ }^{214}$

The projection made by proponents of the CM onto the text of Genesis 1 involves an entire interpretive horizon which borrows a modern scientific notion of cosmology and then reads that back into an ancient document. As I mentioned earlier in Chapter III, this projection is called "concordism." ${ }^{215}$ Concordism is a process of interpretation which attempts to harmonize the meaning of the Bible with current scientific insights. ${ }^{216}$

Concordism, as it is constructed at the CM, is quite confusing for most people. In the Six Days video, a modern version of the cosmos is displayed as the ancient verses are being read. This is essentially a projection of a modern horizon — or set of expectationsonto an ancient document. But the film is so brief, four minutes and forty-four seconds, the average viewer lacks an appropriate amount of time to reflect on the points of dissonance that emerge in the video. In terms of simplicity and clarity, the YEC

\footnotetext{
214 Gadamer, Truth and Method, 269.

215 The term "concordism" has been used as early as 1954 by Bernard Ramm, The Christian View of Science and Scripture (Grand Rapids, MI: William B. Eerdmans Publishing Co., 1954), 144-56.

${ }^{216}$ Concordism is not a common term in biblical studies and its use is generally employed in discussions of creationism - especially young earth creationism and progressive creationism. The best sources are Denis O. Lamoureux, Evolutionary Creation: A Christian Approach to Evolution (Eugene, OR: Wipf and Stock Publishers, 2008); Stanley L. Jaki, Genesis 1 Through the Ages $2^{\text {nd }}$ rev. ed. (Edinburgh: Scottish Academic Press, 1998); and Edward B. Davis, "The Word and the Works: Concordism in American Evangelical Thought," in The Book of Nature in Early Modern and Modern History, Klaas Van Berkel and Arjo Vanderjagt eds. (Leuven, Belgium: Peeters, 2006).
} 
presentation is far easier for a non-specialist (especially biblical studies and astronomy) to grasp than are other forms of concordist creationism. ${ }^{217}$

Denis Lamoureux has written that "concordism commonly refers to a method of biblical interpretation that seeks to find a correspondence between science and Scripture." ${ }^{218}$ The implication here is that concordism is actually a hermeneutic. After several e-mail exchanges with Lamoureux he expressed that literalism and concordism are often intertwined so that people assume that a current phenomenological perspective (current cosmology) was somehow present in an ancient text. Most insightful was Lamoureux's statement "that we must read Scripture in a counterintuitive way.",219 Indeed, this is what Gadamer explained: "Hence, the hermeneutically trained mind will also include historical consciousness. It will make conscious the prejudices governing our own understanding, so that the text, as another's meaning, can be isolated and valued on its own., 220

The CM presentation of the verses of Genesis lacks such an historical consciousness. Ironically, however, the interpretive Achilles Heel of such an approach does emerge in such a way that confounds the most educated proponents at the CM and even Ken Ham himself. As I will explain below, the very literalism upon which the CM insists presents the greatest interpretive problem in Genesis 1. That problem is the meaning of the word "firmament."

${ }^{217}$ For example, progressive creationists like Hugh Ross (Ph.D. in astronomy, University of Toronto) employ detailed astronomical explanations to explain the biblical verses as complicated metaphors that imply a 4.5 billion year universe-Creation and Time: A Biblical and Scientific Perspective on the Creation-Date Controversy (Colorado Springs: Navpress, 1994). While at least the progressive creationists use evolutionary science, they make the interpretation of the ancient biblical texts far more difficult to understand. Furthermore, they propose a meaning for the text that ancient readers would never have imagined-i.e. a multi-billion year old Big Bang cosmology.

${ }^{218}$ Lamoureux, Evolutionary Creation, 14.

${ }^{219}$ Denis Lamoureux, e-mail message to author, September 5, 2008.

${ }^{220}$ Gadamer, Truth and Method, 298. 
The following verses from Genesis 1present the concept of the firmament:

Then God said, "Let there be a firmament in the midst of the waters, and let it divide the waters from the waters." Thus God made the firmament, and divided the waters which were under the firmament from the waters which were above the firmament; and it was so. And God called the firmament Heaven. So the evening and the morning were the second day (Genesis 1:6-8).

Then God said, "Let there be lights in the firmament of the heavens to divide the day from the night; and let them be for signs and seasons, and for days and years; and let them be for lights in the firmament of the heavens to give light on the earth;" and it was so. Then God made two great lights: the greater light to rule the day, and the lesser light to rule the night. He made the stars also. God set them in the firmament of the heavens to give light on the earth, and to rule over the day and over the night, and to divide the light from the darkness (Genesis 1:14-18). ${ }^{221}$

The word "firmament" is an antiquated translation from the Hebrew word Rakia' ${ }^{222}$ The term itself illustrates two of Gadamer's important insights. First, it shows how an interpretive horizon may become clouded, recalling Gadamer's warning that “The important thing is to be aware of one's own bias, so that the text can present itself in all its otherness and thus assert its own truth against one's own fore-meanings.. ${ }^{223}$ Second the translation of the term Rakia' has brought about a significant amount of obfuscation that has further covered over the meaning in its ancient environment-a problem that Gadamer says, "doubles the hermeneutic process."224

Rakia' is an ancient Near Eastern feature of a three-tiered cosmogony. The term is defined in a standard Hebrew lexicon as "the vault of heaven, or 'firmament,' regarded

${ }^{221}$ I quote from the New King James Version because that is the translation used in the Six Days video.

${ }^{222}$ I am assuming that most of my readers are not proficient in Biblical Hebrew, so I have chosen to transliterate Hebrew words rather than placing them as they appear in the Hebrew text. Following The Chicago Manual of Style, $16^{\text {th }}$ ed., I am using the ALA-LC Romanization Tables: Transliteration Schemes for Non-Roman Scripts, com. \& ed. Randall K. Barry (Washington DC: Library of Congress, 1997). http://www.loc.gov/catdir/cpso/romanization/hebrew.pdf (accessed October 10, 2013).

${ }^{223}$ Gadamer, Truth and Method, 271-72.

${ }^{224}$ Ibid., 387. 
by Hebrews as solid and supporting 'waters' above it." ${ }^{, 25}$ The best translations of Genesis use the words "vault" or "dome" instead of the outdated word firmament. ${ }^{226}$ This vault was seen by the Hebrews as the rigid structure supporting the heavenly ocean on top of which was the temple of God. In most introductory textbooks on the Jewish scriptures, a visual diagram, such as Figure 3 (below) is provided.

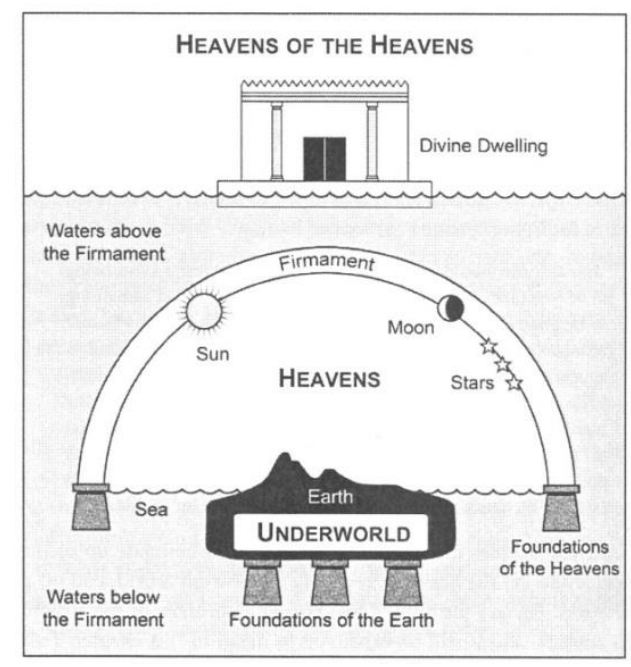

Figure 4. Drawing by Kenneth Kelly in Lamoureux, Evolutionary Creation, 108.

This three-tiered cosmogony has been established mostly through the study of Egyptian and Mesopotamian epigraphy as seen in Figure 4. Represented in Figures 3 and 4, ancient Near Easterners conceptualized the earth as a flat, disc-shaped mass surrounded by a body of water. The upper waters were thought to be a heavenly ocean. The waters below consisted of the oceans and waters of the deep, below the earth. Careful attention to the Hebrew Scriptures bears out this same cosmology. ${ }^{227}$

${ }^{225}$ Francis Brown, S. R. Driver and C. A. Briggs, Hebrew and English Lexicon of the Old Testament (Oxford: Clarendon Press, [1906] 1951), 956.

${ }^{226}$ Robert Alter uses the word "vault" in his excellent translation of the Pentateuch/Torah-The Five Books of Moses: A Translation with Commentary (New York: W. W. Norton, 2004). The New Revised Standard Version translated Rakia' as “dome."

${ }^{227}$ For example, the waters above and a heavenly temple are alluded to in the following passages: Psalm 29:10; 104:3; and 148:4. 
Additionally, the sun, moon, and stars were thought to be connected to the dome-shaped firmament and they ran a circular course above and below the earth on a daily basis.

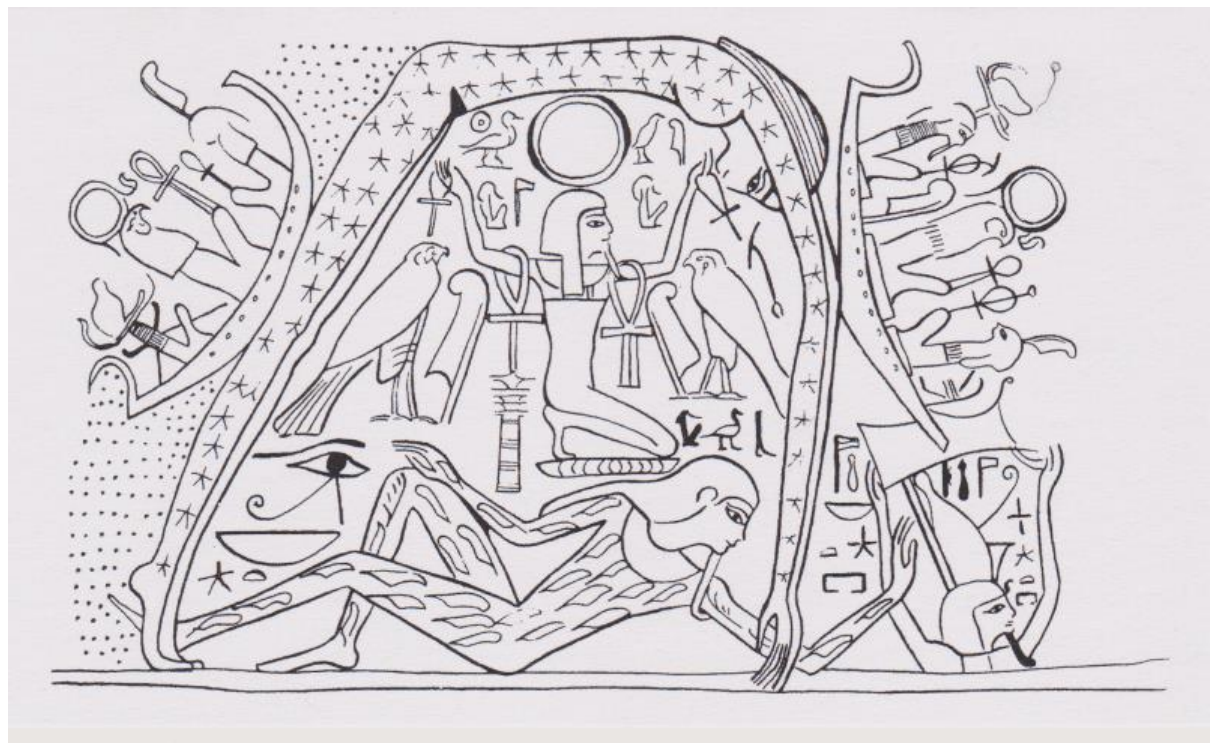

Figure5. Egyptian epigraphy showing a corporeal form of the earth, firmament (the woman's arched body), and the heavenly sea (traversed in a boat by the sun deity). ${ }^{228}$

The three-tiered cosmogony was held by Near Easterners until well into the second and third centuries CE. References to this cosmogony are even found in the New Testament. ${ }^{229}$ The clarity of Genesis 1 rests upon this ancient understanding. Moreover, it is my hypothesis that the concept of the firmament is the key to understanding the text of Genesis. As will be documented below, when I asked the leading thinkers at the CM what the firmament actually is - because everything in that chapter must fit with modern cosmology — they were at a loss. Here, the importance of Gadamer's metaphor of and interpretive horizon is quite clear.

${ }^{228}$ This Egyptian drawing is found on a Papyrus from the New Kingdom, Egypt (dated 1570-1085 BCE). Othmar Keel, The Symbolism of the Biblical World: Ancient Near Eastern Iconography and the Book of Psalms, Trans. Timothy J. Hallett (New York: The Seabury Press, 1978), 36.

${ }^{229}$ St. Paul's letter to the Church at Philippi contains the interesting verse: "Therefore God also highly exalted him and gave him the name that is above every name, so that at the name of Jesus every knee should bend, in heaven and on earth and under the earth" Phil. 2:9-10 [emphasis mine]. New Revised Standard Version. 
At the $\mathrm{CM}$, there is no reference to any ancient conceptualization of a firmament as described above. When I asked the most credentialed astronomer at the CM, Danny Faulkner, ${ }^{230}$ if he would explain the concept of the firmament, the following was his response:

Me: In Genesis, the Rakia' or firmament, could you conceptualize, on the day that that [firmament] was created, what was that?

Faulkner: [[Laughs]] I wish I knew. Okay, the Rakia' is, it comes from a, it's a noun that's been made out of a verb. Which is, I understand, a common thing in Hebrew...It refers to something that has been spread out, even beaten, perhaps like some sort of metal, what they mean is usually Gold. It can spread out very nicely, hammered out. So something that has been stretched as it were, and it is interesting that the Old Testament elsewhere talks about the stretching of the heavens. So there was something that was spread out at that point. Kind of expanded and made bigger. Of two primary schools of thought. One of those is that it [firmament] refers to the atmospheric heaven because it says that He [God] called "heaven" or shamayim, $\left[{ }^{231}\right]$ which is a word for heaven. The other school of thought is it [the firmament] refers to space outside of the, the atmosphere of the earth. Because that too, could be heaven. Some people actually convolve those and say they believe it's both. Some of the modern translations have "expanse" or "sky" and sky is a bit of wiggle room as well because it could be the atmosphere ...but the problem is that it explicitly states that Jesus, I mean God, called the Rakia" "Shamayim." Called the "firmament" "heaven." But birds are said to be in the firmament and stars are said to be in the firmament of heaven-or across the face of it. So whatever it is, uh, clouds can appear in it, birds can appear in it, the sun can appear in it and the stars can appear in it. So that gives the idea, again, of space but hey the atmosphere is what we see there. Even today we say, "Look up in the sky and you see a star, and you see the sun, and you see the moon, and you see birds and you see clouds. So that's where the whole thing comes down. I don't know whether it was atmosphere, space, or both.

Faulkner struggled to explain the concept of the firmament in modern terms of what scientists now know about outer-space. The basic problem was that the concept of a

${ }^{230}$ Danny R. Faulkner holds an M.S. in physics from Clemson University, an M.A. and a Ph.D. in astronomy from Indiana University. He is Professor Emeritus from University of South Carolina (Lancaster) where he served as Chair of the Department of Science, Nursing, and Public Health from 2009 to 2012.

${ }^{231}$ The Hebrew word Shamayim is defined as "heavens" or "sky." Francis Brown, S. R. Driver and C. A. Briggs, Hebrew and English Lexicon of the Old Testament (Oxford: Clarendon Press, [1906] 1951), 1029. 
firmament held by ancient Near Easterners was obviously a phenomenological ${ }^{232}$ idea of their own time. It was no more real than the sun deity going across the ocean in a boat. But for YECs, whatever is referenced in Genesis 1 is an exact and fully accurate scientific description of reality. In the minds of YECs, modern scientific models are not even accurate enough because they are only theories and not the true reality which only God knows.

Every other object in Genesis 1 (i.e. sun, moon, stars, people, animals, plants, land, sea, etc.) is understood as pretty much the same in ancient times as they are nowthe big exception being the distances of heavenly bodies. The firmament however, is a totally ancient concept that is so far removed that most people today have no idea of what it was because they also lack a mental picture of the ancient universe. As I will also discuss below, translations of the word Rakia' have added a great deal of obfuscation for the vast majority of Bibles. As such, every person I interviewed on this point struggled to explain the concept in much the same way as Faulkner. For example, the following interviews demonstrate just how difficult this term is. In an interview with Terry Mortenson, ${ }^{233}$ I posed the following question:

Me: With the whole concept of the firmament, how would you conceptualize it?

\footnotetext{
${ }^{232}$ I use the term "phenomenological" here to describe primarily the language used to describe phenomena by the ancient Near Easterners. Lamoureux elaborates on the sense in which I use phenomenological: "Observation in the ancient world was limited to unaided physical senses, but scientific instruments, like telescopes, have broadened our view of the universe. As a result, it is essential to understand that statements in Scripture about nature are from an ancient phenomenological perspective. What the biblical writers and other ancient peoples saw with their eyes, they believed to be real, like the literal rising and setting of the sun. In contrast, we view the world from a modern phenomenological perspective. When we see the sun "rising" and "setting," we know that it is only an appearance or visual effect caused by the rotation of the earth. Consequently, it is crucial that these two different viewpoints of nature not be confused or conflated." Evolutionary Creation (Eugene, OR: Wipf and Stock Publishers, 2008), 109.

${ }^{233}$ Terry Mortenson holds an M.Div. from Trinity Evangelical Divinity School and a Ph.D. in the history of science from Coventry University in the UK.
} 
Mortenson: As I've studied the Hebrew, text in Genesis 1...the word expanse in Hebrew is Rakia' and so God created the Rakia' on day two, he separated the waters above from the waters below. On day four, he created the sun, moon, and stars and three times it says that the sun, moon, and stars are in the Rakia' and one time it says that he placed them in the Rakia'. And then on day five, most of the English translations are not literal, when it describes the creation of the birds in one phrase. It says, in verse twenty, then God said let the waters teem-I'm reading from the New American Standard-with swarms of living creatures and let the birds fly above the earth in the open expanse of the heavens. The King James, the New King James, no, the King James the ESV [English Standard Version] almost all of the translations have something virtually identical to that In the open expanse. But the Hebrew, the, the New King James is the only one that translates the Hebrew literally at this point $\left[{ }^{234}\right]$ because it says, upon the face or across the face of the expanse. And the phrase 'upon or across the face' is $A l$ peney, in Hebrew, the same phrase that is used in verse two where it says "the darkness was on the surface of the waters and the Spirit was moving on the surface of the waters," it's the same, word that is used in chapter seven verse three that, God wants to repopulate the earth after the flood- "on the face of all the earth." Throughout the flood account, you know he's gonna wipe out all the creatures on the face of the earth. So Genesis says that the birds are flying on the face of the expanse, the sun, moon, and stars are in the expanse, which means that the waters above are not the atmosphere between the birds and the sun, moon, and stars. It's at the outer boundaries of the universe and however mind-boggling that is to us, in my mind that's what the text says and then if you look at the use of Rakia' in the rest of the Bible, it's always associated with the heavenly bodies. Never with the birds. And in Daniel 12:3 it talks about, um, the people who are faithful to the Lord. Let me look it up here quick. It says, "Those who have insight will shine brightly like the brightness of the expanse - the Rakia' — and those who lead many to righteousness like the stars forever and ever. So the parallelism says the stars are in the Rakia' of the heaven. And in Psalm 148, I think it is, yeah, verse four it says the waters above are still up there. At least at the time of the Psalmist. Praise God from the highest heavens, and the waters above the heavens...

Me: What are those [i.e. waters above the heavens] do you suppose?

Mortenson: Well, the only thing I can think of is that it's referring to the waters above...

Me: Yeah, but they are still there?

${ }^{234}$ The point to which Mortenson alludes is the New King James versions translation of Genesis 1:20 as "and let the birds fly above the earth across the face of the firmament of the heavens." The underlined is emphasized as the focus of Mortenson's explanation. 
Mortenson: I'm not denying that they're, I can't say that there was no canopy $\left[{ }^{235}\right]$, I'm just saying that the second day in Genesis 2 doesn't teach a vapor canopy. And Genesis 7:11 where it talks about the windows of heaven doesn't clearly teach a canopy either. So it's not biblically required.

Me: So if I hear you right, we're talking about the concept of, for lack of a better word, deep space?

Mortenson: Mmm, hmm [affirmative gesture].

Me: But then the waters above I don't know what to do with those. I don't know where to place those...

Mortenson: Yeah, except the only thing I could see is that they're at the outer boundary of the universe. Russ Humphreys, he's taken that same approach. He says that, contrary to what the evolutionists say, the universe is bounded. ...to me, it's not a problem if I don't understand how something could be. You know, I don't know how Jesus could be born of a virgin or walk on water or rise from the dead. The question is what does the text teach? And is this figurative language. That's a possibility. There's figurative language in the Bible....But I can't get my head around how God could form man from the dust of the ground. Or a woman from the rib.

At this point in the interview, I sensed that Mortenson was getting a little frustrated as I pushed for particularities as they challenged any modern explanation. This comes through as Mortenson changed the attempt to physically describe what the Rakia' actually was, or in his case "is," to a default position of explaining that he would still believe what the text said — even if he lacked a rational, scientific explanation. Then he indexed miracles from Jesus and the creation of Adam from dust and Eve from a rib to say that a full explanation was not his ultimate problem. This was my repeated frustration. On one hand they claimed that all true science points to the biblical account of creation. But when confronted with non-scientific ideas, they defaulted to the supernatural power of God.

\footnotetext{
${ }^{235}$ Here, what Mortenson means by a "canopy" refers back to a theory by John C. Whitcomb and Henry Morris who advocated the existence of a water canopy surrounding earth in the days prior to Noah's flood. This water canopy, according to Morris and Whitcomb, was water above the firmament, but that it was drained as it produced Noah's flood. Thus, it no longer exists.
} 
What is obvious is that the current understanding of the universe in terms of distances - including stars and galaxies such as Orion's Belt that are millions of billions of miles away from earth - is thought to be embedded in the meaning Genesis 1. This is due to the presupposition of inerrancy. The particular view at the $\mathrm{CM}$ is that anything to which the Bible refers is in a category of absolute truth. This view is something Ham refers to repeatedly. "The acceptance of the literal events in Genesis is foundational to the question of biblical inerrancy."236 In other words, the descriptions in Genesis are exactly how the material cosmos came to be.

Informants did not use ancient Near Eastern parallel literature or epigraphy in an effort to understand the word Rakia' in its original sense. ${ }^{237}$ When one reads Genesis 1 as an ancient story of creation as ancient Near Easterners would have conceptualized it, all the problems disappear. However, this is not an option because it poses a threat to the literal scientific and historical accuracy of the Genesis account.

In one case, an informant came close to admitting that the language of the Old Testament should be considered as sharing features of ancient Near Eastern literature. ${ }^{238}$

Me: How would you conceptualize this concept ... of the Rakia' in Genesis 1, sometimes translated "firmament" or "expanse"?

Informant A: That is an interesting question. I've not done a ton of research in that area but it's one that I want to get into. I've been for about a year-and-a-half

${ }^{236}$ Ham, The Lie, 183.

${ }^{237}$ With the exception of one informant, which I explain below, not a single person interviewed posited the idea of a three tiered cosmology. In fact, when I asked Danny Faulkner if he had heard of such a view he said that he had not. Biblical criticism is one of the most neglected fields of study at the CM. It is also interesting that although they have scientists with terminal degrees - Georgia Purdom (Ph.D. Mollecular Biology, Ohio State University), David Menton (Ph.D. Biology, Brown University), and Danny Faulkner (Ph.D. Astronomy, Indiana University) — they do not have a single Old Testament scholar with a terminal degree on staff.

${ }^{238}$ In the case of this informant, I have chosen to conceal his identity. While I have signed permission to both identify his name and title, and to use direct quotes, I chose to refrain from doing this because he made the admission (transcribed above) that he hoped what he said did not get him into trouble. Because this dissertation is a public document, I chose to conceal his identity for fear that his job may be in jeopardy. I will refer to him as "Informant A." 
now, since I finished my thesis, I got interested in this subject. There's been a, um, the liberals have been doing this for a while. But I think in the last, maybe forty or fifty years or so, it has become more popular among evangelicals to say that the Bible is using ancient Near Eastern motifs. And I think, [Pause] this might get me in trouble [laughs] I think there is some truth in that. But I think most people go way too far. I think what they do is they look and say they were borrowing all these things as Israel's own story. I don't think that's what it is. I think that they used some of the terminology. In fact I think it's pretty easy to demonstrate that. But it didn't mean that was exactly how they viewed things. So, it could be phenomenological language, where this is what would appear to the observer. You look at the sky and it looks like a blue dome on a nice clear daylike today. So it could be that simple. Much of the language that's used, that the people who say that the ANE literature, you know, where you've got the pillars of the earth and you have the flat, disc-shaped earth and then you've got the dome above it. Almost all of that comes from the Psalms or from Job-from the poetic texts. There's very few verses at all that they pull from historical narrative. But Rakia' would be one of them.

Me: But - I don't know if you are aware of this - they also pull from Egyptian and Mesopotamian epigraphy, where there is a heavenly ocean and a corporeal representation of the firmament, with a boat going across a heavenly ocean. So what is that thing called a firmament?

Informant A: Yeah because when you separate the waters from the waters, what is left in between there is sky, the heaven.

Me: Not only that but you have the sun, the moon, and the stars are in the firmament.

Informant A: Yeah, and birds fly in the face of it. So is it that the firmament is the edge of the universe-I mean, that it's so far out there and that the sun, moon, and stars are part of the expanse?

Me: And that the waters above are beyond that though.

Informant A: Right, so the waters are beyond that. I think Humphreys [ $\left.{ }^{239}\right]$ proposed that back in the nineties. But again I don't know, because you could have that language of appearance where the stars are in the firmament. And I think that because as a ministry we are so focused on trying to scientifically explain or at least make it fit with scientific understanding, sometimes we, maybe we are guilty sometimes of reading scientific material into something that is not meant to be scientific. ... That's a good question. It's one that I wish I had a better answer for you.

${ }^{239}$ Informant A is referring to D. Russell Humphreys, one of the few YEC Ph.D. Astronomers, who has written some papers on cosmology for creationists. 
Informant A was by far the most educated in the field of biblical studies. Through my questions he articulated the very problem that I have described as concordism when he replied that "maybe we are guilty sometimes of reading scientific material into something that is not meant to be scientific." But as the interview unfolded, it became increasingly difficult for him to give a cohesive conceptual description of the Rakia'. But the most surprising answer in all of the interviews was the one given by Ken Ham.

Me: One of the hardest concepts I have with Genesis 1 is the word Rakia' or firmament. What is that thing called the firmament? How would you describe it?

Ham: What did Terry [Mortenson] tell you?

Me: He looked at it, and hopefully I'm not messing up his articulation of it, but I think his view was more the idea of deep space.

Ham: Well on day five it says that the birds are going to fly across the face of the firmament. So, you know, I, sometimes for some of these things... [Pause] I look at it from the perspective of that there's continuity between the world before the flood and the world after the flood. And even though the flood has greatly affected things and even though sin has affected things there still has to be some degree of continuity. Right? When the birds fly across the face of the firmament, they're flying in space but they're flying within the atmosphere, right? I mean, from a perspective of teaching children, I always tell them God was making the, uh, God was making the atmosphere on day three, I mean day two, um, when he said, 'Let there be a firmament in the midst of the waters.' And then divided the waters from the waters.. Then God made the firmament and divided the waters which were under the firmament from the waters above the firmament. When you look at um, 2 Peter $3,\left[{ }^{240}\right]$ it seems to indicate that everything was made out of water. That water was the element that God used, you know, um, for this they willingly forgot that the heavens and the earth existed and perished. Basically, it

${ }^{240} \mathrm{Ham}$ is referring to an obscure verse in the second Petrine epistle. The verse reads as follows: "They deliberately ignore this fact, that by the word of God heavens existed long ago and an earth was formed out of water and by means of water, through which the world of that time was deluged with water and perished" 2 Peter 3:5-6 (New Revised Standard Version). There are at least two major schools of interpretation on these verses. First is that taken by Bo Reicke, who maintains that "an earth formed out of water is an allusion to Noah's flood. In this case the antediluvian world topography was changed. The Anchor Bible: The Epistles of James, Peter, and Jude; A New Translation with Introduction and Commentary, vol. 37 (Garden City, New York: Doubleday \& Co., 1964), 175. Second is the view offered by Richard J. Bauckham in which he understands the verses as alluding to the mythical ancient Near Eastern account of the creation of the world out of a watery chaos. Word Biblical Commentary: Jude, 2 Peter, vol. 50 (Waco, Texas: Word Books, 1983), 297. Ham seems to be asserting a view that God made every physical object out of water, a view closer to Bauckham's but without ANE understanding. 
goes on to say that "out of water and by water were the things that were made." So, is it that he was making the atmosphere and making space? Is it both things? Because he divided the firmament. I'm not a Hebrew expert, but the birds are flying on the face of it. But I think that Terry would see that as the deep space, right? That they are flying on the face of the firmament?

Me: Right, that that [the face] would just be one level of it. The difficulty for me, and I have translated the first three chapters, is that if it is deep space, then you've got waters beyond that...

Ham: My understanding is that there is water out there, right? Water in the form of ice. And so on. And also that God could have used that water to make everything else. You know he made a basic element which is why I point to second Peter three which indicates, you know, for instance on day one he made the earth covered with water, then he separates the firmament and the waters above and the waters below. So maybe he used that then, that element, to create the rest of everything. So that one, yeah, I don't talk about it too much. And it might be concepts that God's putting to us, but in ways that we can't understand about God and how he created it so he's giving us things in a basic way.

For Ham, the concept of the firmament is problematic because he, like the informants above, actually believe that the Rakia' is a real entity. The fact that the word appears in Genesis 1 necessitates that it has an actual existence in the world-just like the sun, moon, and stars from the same chapter. Because of their particular version of inerrancy, to admit that the writer of Genesis was wrong about cosmology is tantamount to saying that God is wrong. If the text says that God made a firmament, then there must be one. It was surprising that Ham admitted that he did not "talk about it too much [i.e. the firmament]." The main reason for my surprise is that he often says to lay audiences that the chapter is straightforward and that any literate person can understand it.

With the exception of Informant A, all the other interviewees tried to explain the firmament using current understandings of the cosmos, including the distance of stars and an expanding universe. Thus, the only option is exactly that about which Gadamer warned. "The important thing is to be aware of one's own bias, so that the text can 
present itself in all its otherness and thus assert its own truth against one's own foremeanings." 241 The informants were either unaware and/or closed to the possibilities that the Rakia' was an ancient phenomenological construct that is far removed from modern concepts of the cosmos. Once more, Gadamer's words prove to be accurate: “A person who has no horizon does not see far enough and hence over-values what is nearest to him. On the other hand, 'to have a horizon' means not being limited to what is nearby but being able to see beyond it." 242

Later in Truth and Method, Gadamer calls this hermeneutic mistake the "axiom of familiarity." He defines the term as follows: "The axiom of familiarity is that things must always have been just as they are for us, for things are naturally like this." ${ }^{243}$ It is fitting to bring in the term concordism here. In the attempt to interpret Genesis 1, my informants made every effort to make those ancient verses concordant with modern notions of science. What they in essence are doing has been called "eisegesis." Eisegesis is a Greek word defined by Richard Soulen as "the practice of reading into a text the meaning which one wants to get out of it."244 Eisegesis is the opposite of "exegesis"- - to draw out the meaning as close to the original intention of the author as possible.

This specific form of eisegesis may also be called "concordism" because here the interpreter is trying to understand the text in terms of modern scientific notions. Stanley Jaki calls this error the "greatest peril" for the interpretation of Genesis 1 . He writes that this hermeneutic mistake is caused by "the ever recurring temptation to make that magnificent chapter appear concordant with the science of the day in order to assure its

${ }^{241}$ Gadamer, Truth and Method, 271-72.

${ }^{242}$ Ibid., 301.

243 Ibid., 355.

60.

${ }^{244}$ Richard N. Soulen, Handbook of Biblical Criticism, $2^{\text {nd }}$. ed. (Atlanta: John Knox Press, 1981), 
cultural respectability." ${ }^{245}$ Once more, Gadamer emphasizes the need to exercise a historical consciousness to guard against such misunderstandings, especially of ancient texts. "Hence the hermeneutically trained mind will also include historical consciousness. It will make conscious the prejudices governing our own understanding, so that the text, as another's meaning, can be isolated and valued on its own." ${ }^{246}$ Reading Genesis 1 with modern eyes precludes one's ability to do what Gadamer insists is so important - i.e. to isolate and value a text on its own terms.

The CM has imposed a modern horizon onto an ancient one. This imposition on the text of Genesis 1 has caused an inevitable dissonance to arise. Such disharmony is demonstrated in the interviews I conducted. I did not get a clear articulation to the question of what the firmament actually was. The only two options for a description of the firmament were the sky and deep space. Faulkner said that maybe it was both. The problems with trying to place modern notions of the vastness of the expanding universe - a point that Faulkner granted to the secular scientific consensus - onto the firmament is that it requires the sun, moon, and stars to be in it. The second problem is that there is a vast body of water said to be above it. ${ }^{247}$

${ }^{245}$ Stanley L. Jaki, Genesis 1 Through the Ages, $2^{\text {nd }}$ ed. (Edinburgh: Scottish Academic Press, 1998), 32.

${ }^{246}$ Gadamer, Truth and Method, 298.

${ }^{247}$ Dissonance is provided even in the prepositions that qualify the nouns involved. For example, ancient notions of the cosmos thought the sun to be "up." Technically, "up," is wrong in scientific terms. "Outside" or "circling" would be more accurate. 


\section{The Obfuscation of Meaning through Translation}

Gadamer calls our attention to a crucial aspect of interpretation as it relates to translating words from one language to another. "Thus every translation is at the same time an interpretation. ${ }^{248}$ Those who have been trained in a language other than one's own realize this important observation. Words always carry nuances that differ from one language to the next. One reason why the word Rakia' is so difficult for modern interpreters to grasp is due to the unhelpful translations of the word into Englishespecially with respect to some recent popular translations. The single most unhelpful translation of Rakia' into English is the word "expanse."249 The archaic word "firmament" reflects the Latin translation from Jerome's Vulgate version. ${ }^{250}$

At least the English word firmament preserves the idea that this was a firm object, as reflected in the Latin (firmamentum) and in the Greek (stereōma). However many current translations, especially those popular with conservatives and evangelicals, translate Rakia' as "expanse." Expanse is hard to define when attempting to contextualize an actual entity created on the second day of creation. The term expanse has two short glosses in a standard dictionary: 1) a large, open area or unbroken surface; wide extent;

${ }^{248}$ Gadamer, Truth and Method, 298.

249 "Expanse" is used in the New International Version, the New American Standard version, and the recently popular English Standard Version. Expanse is an unhelpful appropriation which stems from the verbal root Raka, meaning to "hammer out" a piece of metal. The idea is that of a blacksmith hammering out a piece of metal into a bowl or shield. While the metal does technically "expand," it does not refer to an expanse of space, air, or atmosphere. Rather, it is a hard, dome-like structure. Thus, the most helpful translations (Alter, New Revised Standard Version, The Jerusalem Bible) use either "dome" or "vault" as translations of Rakia'. Even the Septuagint (LXX) translation uses the Greek word stereoma, defined as "the solid part, firmament," William F. Arndt and F. Wilbur Gingrich, A Greek-English Lexicon of the New Testament and Other Early Christian Literature, $2^{\text {nd }}$ ed. Trans. Walter Bauer (Chicago: The University of Chicago Press, 1979), 766.

${ }^{250}$ The King James Version of 1611 uses "firmament" as a translation of Rakia' because of the Latin word firmamentum used in the Biblia Sacra Vulgata. This term has long fallen out of vernacular use in North American English. 
great breadth; 2) expansion. ${ }^{251}$ This nebulous definition works in two interesting interpretive ways.

First, a surface interpretation of expanse provides much flexibility in terms of concepts. For example, one conservative study Bible provides the following footnote in attempting to explain "expanse" in Genesis 1:6. "The Hebrew word refers to an expanse of air pressure between the surface of the sea and the clouds, separating water below from water above.”252 Another popular evangelical study Bible contains a similar footnote: "expanse. The atmosphere or "sky" (v.8), as seen from the earth."253 Over time, expanse took on meanings ranging from "sky" and "atmosphere" to "heaven" or "the heavens above." With the cosmological data we now have, some of my informants proposed that the Rakia' is actually something like deep space, extending to the end of the universe. Translating Rakia' as an expanse actually obscures the word's original meaning as it fails to identify this object as something that ancients thought to be dome-shaped, rigid, and strong enough to support a heavenly ocean above.

Gadamer's comment about the compounding of interpretations is relevant here. "Having to depend on an interpreter's translation is an extreme case that doubles the hermeneutical process, namely the conversation: there is one conversation between the interpreter and the other, and the second between the interpreter and oneself." Throughout Jewish and Christian history, translations have concealed the meaning of the Rakia'. The progression in translations from Rakia' to stereōma in Greek and then to firmamentum in Latin and then to firmament in Shakespearean English to the modern

${ }^{251}$ Webster's New World Dictionary, $3^{\text {rd }}$ College ed. (New York: Simon and Schuster, 1988).

${ }^{252}$ The Net Bible, $1^{\text {st }}$ ed. (Richardson, TX: Biblical Studies Press, 2005), 3.

6.

${ }^{253}$ The NIV Study Bible, $10^{\text {th }}$ anniv. ed. (Grand Rapids, MI: Zondervan Publishing House, 1995),

${ }^{254}$ Gadamer, Truth and Method, 387. 
gloss "expanse," resulted in layers of accumulated meaning that changed the concept over time.

Second, translating Rakia' as "expanse" causes tremendous difficulty if critically examined. This was demonstrated in the interviews I conducted. Because the word has such a wide semantic range, an expanse could be something small to something extremely large, like outer space. All the informants assumed that whatever is being described in Genesis 1, must match perfectly with the world as we observe it today. Thus, the problems become insurmountable. If the expanse is the atmosphere, then how could the sun, moon, and stars be set or placed in that expanse (Genesis 1:17)? In that case the sun would destroy earth in an instant. But if the expanse is deep space, then what are the waters above the firmament? In one of my interviews, Danny Faulkner suggested that maybe there is water beyond the edge of the universe and we just haven't found it yet. When I asked if he could cite any model that was published by astronomers on such an idea, he replied that he could not.

What is incredibly interesting to me is the extent to which YECs will go to support their view of this ancient text. Not a single informant could give me a cohesive definition of what the Rakia' actually is or was. For all the informants, whatever the Rakia' is, it is still out there and we must use modern astronomical categories to describe it. Gadamer discusses just this type of hermeneutical error in Part Three of Truth and Method - “Language as the Medium of Hermeneutic Experience.” In the following quote, Gadamer is referring to a hermeneutical error made by historians who fail to carefully see the difference of the concepts between themselves and the writers far removed. "Thus, 
despite his scientific method, he behaves just like everyone else - as a child of his time who is unquestioningly dominated by the concepts and prejudices of his own age." 255

Sensing some openness by Dr. Faulkner, I showed him the diagrams in Figures 3 and 4 of this chapter. However, he dismissed them on the basis that he believed that the expanse was something malleable and spread out—like air or space. At this point, our interview got a little tense as I asked about the possibility of the Rakia' being rigid or firm. The following dialogue ensued:

Me: When I try to make phenomenological sense of Genesis 1, this [gesturing to the ANE diagrams and epigraphy sketches of Figures 3 and 4] makes more sense to me.

Faulkner: But when you talk about this [pointing to the diagrams] you've got the uh, again, the Rakia' is translated as stereoma in the Septuagint. Jerome goes with firmamentum which is then transliterated in the King James as "firmament." And, and modern translations are now saying "sky" or "expanse."

Me: I don't think those are good translations.

Faulkner: You think so? No, the Hebrew word there, Rakia' [pause]

Me: Which comes from the shoresh root Raka the verb for "to hammer out, a piece of metal"...

Faulkner: Or to beat out, and what I'm thinking of, well what kind of metal do you likely beat out?

Me: Bronze Age is the time period. Something that was malleable but these were Bronze Age technologies essentially, so it would be something like a shield or a bowl...

Faulkner: Or don't overlook gold?

Me: Or gold...

Faulkner: I mean today, gold is a perfect example and, and what's neat about gold is that it is very malleable. You know physically, with rollers and hammers, you can beat gold out so that it's only a few atoms thick. And you can see light

${ }^{255}$ Ibid., 397. 
shining through it. It's amazing. Now the thing is, do you think of gold as being [knocks twice on desk with knuckle] hard?

Me: Yeah.

Faulkner: No you don't.

Me: Well...

Faulkner: Have you ever handled twenty-four carat gold?

Me: Well, yeah, I think of it like this [removing my wedding ring] ...

Faulkner: That's twelve or fourteen.

Me: Okay. Well, but...

Faulkner: But gold is the stuff you spread out like on the temple [referring to Solomon's temple] and gold like on the ark of the covenant, that gold leaf, that's twenty-four carat.

Me: Are you sure it was twenty-four carat? I mean, how do you know there's no verse that I'm aware of that says "it's twenty-four carat," I mean, ...

Faulkner: That's, that's the way it's done today and when you have gold leaf it's twenty-four carat, pure gold. And the reason you do that is that you want it to be malleable. When you alloy it, the purpose of alloying it is that it makes it hard. Like in the old times when a cowboy would take gold and bite it and it gives.

Me: I get that, but ...

Faulkner: So the idea that I'm thinking of this word Rakia' has been beaten or if you will spread, out, or stretched out, you know where we find elsewhere in the Old Testament. I'm thinking of something that is, not necessarily hard but simply stretched. I think we can say to people made, okay this is beating out something such as a metal, but, but then what's a common characteristic of metal? Oh it's hard. Well, in many cases it is, but in some cases such as gold leaf, it's not hard. The important thing there is that it's stretched out. So by zeroing in on the thing having to be hard, they miss the whole point perhaps. Because the thing is spread out is the important feature there. So it has nothing to do with hardness. But if you insist that it has to be hard, then you get this dome that is made out of crystalline stuff, or made out of concrete or whatever. All of these are very hard sorts of things. But I don't think the Hebrew text says that.

Me: Well, the Hebrew text doesn't go that far, but, what I'm trying to say is that they didn't just hammer gold, they hammered a lot of metals ... 
Faulkner: Oh yeah, well they did hammer some things, particularly bronze. And they could do it with tin and copper, remember tin and copper, if you've ever handled those, they're pretty soft...

Me: Yes, but they also dealt in hard metals and they heated them. They had the technology to heat and shape even the harder metals...

Faulkner: But I think the interesting thing is that there is a spreading aspect to this. I'm sure they could have used in Hebrew, a word for something that is hard. But they didn't do that. It emphasized the fact that it was spread out and I think that's the important thing here. Whatever it is it has been spread out. It starts off small and now it's big, much bigger. And when you combine that with the Old Testament prophetic and poetic books, the heavens being stretched out, I think the parallel is very striking that the important thing is the stretching or spreading, so to insist that it has to be hard, I think is a real mistake. A real mistake.

Me: Well, certainly if you're going to insist on making it the universe, or space or something, you can't [i.e. read it as "hard" or "rigid"]....

Faulkner: Or, if it's the atmosphere, coming back to my preferred opinion that it's the atmosphere.

Me: Then you've got the sun in it [an astronomical impossibility].

Faulkner: Again, we have the sun, we have the birds in the sky, we have the stars in the sky. Then we get back to this thing, firmament of heaven, what does that mean? I think that means "sky." For the most part. It's tricky, we even use that language today.

Me: Well, at any point, if you shift your view around there to define that thing [i.e. Rakia'] you end up making another part [i.e. sun in the atmosphere] phenomenological...

Faulkner: Yeah, but I think that in these two diagrams [Figures 3 and 4] they are attempting to try to interpret. They are trying to tell us what Moses wrote, thirtyfour hundred years ago. Through the lens of nearly two millennia of erroneous church teaching. And that's the real problem. That, that I reject this cosmology because this was a rip-off of ancient Greek cosmology.

Me: So Moses, $\left.{ }^{256}\right]$ in your mind, Moses knew exactly how big the universe is? I mean, he knew what we know today and was trying to write...

Faulkner: No, no, no. He was acting under the inspiration of the Holy Spirit.

${ }^{256}$ Here, I use Moses because the CM assumes that Moses wrote the Pentateuch - a position that I do not hold. But knowing their position, I use it because I wanted to avoid another digression. 
At this point in the interview, we digressed from the topic of the Rakia'. It became obvious to me that Faulkner could not consider that the Rakia' was an ancient idea that is not representative of the scientific reality that exists today. He affirmed all of the current observations about the cosmos as the consensus of secular astronomers-including the distances to stars and galaxies, and the red shift of expanding planetary bodies. His closing statement in the interview above finally arrives at the underlying and most important projection, to borrow Gadamer's term. That projection is “inspiration of the Holy Spirit." Indeed, this is the operative concept that guides all other hermeneutic processes at the CM. The doctrine is also deeply interwoven into the idea of inerrancy. Once again, because the Holy Spirit, or God, inspired every word, and because God cannot say anything untrue, therefore there is no error in any part of the Bible. So Faulkner's response included the denial that Moses actually knew what he was writing. For Faulkner, whatever Moses was writing, it was exactly as the universe appears today to astronomers.

Faulkner's answer to one of my questions was revealing to me one a number of levels. I asked how plants could grow before the sun was created. ${ }^{257}$ I was expecting a rather detailed and complicated answer. Faulkner replied, in a most casual way, that all plants need was light and heat, and that they had both. He was referring to day one of the creation week: "Then God said, 'Let there be light,' and there was light." ${ }^{258}$ He claimed that with heat there was also light. What he and others believe about this problem of plants before a sun, is that God supernaturally provided light and heat for at least twenty-

\footnotetext{
${ }^{257}$ Plants are said to be created on day three (Genesis 1:11) but the sun was not created until day four (Genesis 1:14). This posed a rather obvious problem, even though I am not a scientist.

${ }^{258}$ Genesis 1:3, New Revised Standard Version.
} 
four hours, enough time needed until the sun could be created. Faulkner then described,

in a rather lengthy response, how marijuana plants can be grown without sunlight. ${ }^{259}$

I realized here that I didn't really need to pursue my lines of questioning any

further. The interpretation of the Genesis 1 happened in six, twenty-four hour days.

Whatever science continues to tell us about the world was somehow present in the

Genesis account. ${ }^{260}$ In some ways, I have to admire the level of faith it must require to

hold such a position. This is especially so for someone with the critical thinking skills

necessary to earn a research doctorate from a reputable university such as Ohio State and

Indiana University.

With respect to the obfuscation caused by the poor translation of Rakia' as

"expanse," a creative impulse arises from the changing of the word from a "rigid dome"

to an amorphous word such as “expanse." This drives people like Dr. Faulkner to grasp at

the softness of gold to try to redefine the Rakia' in a way that fits his own horizon of

modern astronomy. ${ }^{261}$

${ }^{259}$ This discussion took place in a follow-up interview and Dr. Faulkner went on at length about how marijuana plants are grown with lights. The scientific problems with the CM's interpretation were always rescued with an appeal to the supernatural. I suppose this should have been obvious all along, but I was confused by all the Ph.D. credentials with the four scientists I interviewed. In other words, why were they trying to appear "scientific" when they only needed to say that the creation account was all a big miracle anyway? I plan to delve into this more in Chapter 5, "Science Redefined."

${ }^{260}$ This is actually a fascinating concept because the CM criticizes science for continuing to change positions on certain theories - like the shift from steady state to big bang. As I have explained, this is science's strength, not weakness. But Dr. Faulkner is actually hopeful that future explorations in astronomy_including secular astronomy - will shed light on the truthfulness of Genesis 1 . This is why he proposes water at the edges of the universe that might account for background radiation. There is no published material on this theory, by his own admission. But if the Rakia' is said to have water "above" it, and if the Rakia' means "deep space," then there is most certainly water out there and future scientists will find it.

${ }^{261}$ I travelled to Hebrew Union College (Cincinnati campus) to access the best Hebrew-Aramaic lexicons. While the term can be used as a synonym for "sky," there is no mention of the Rakia' as a soft, expanding space as Faulkner endeavored to explain. The definition for Rakia' is as follows: "by רִיָָ was understood the gigantic heavenly dome which was the source of the light that brooded over the heavenly ocean and of which the dome arched above the earthly globe," The Hebrew and Aramaic Lexicon of the Old Testament, Ludwig Koehler and Walter Baumgartner, vol. 3, trans. \& ed. M. E. J. Richardson (New York: E. J. Brill, 1996), 1290. 


\section{$\underline{\text { Conclusion }}$}

As I have read over the transcripts of my interviews and the published materials produced at the CM, their hermeneutic approach turns out to be what I had hypothesized. Genesis 1, and the Bible in its entirety, is the definitive account of how the universe began and continues today. The CM interprets every word in Genesis 1 as literally as possible. However, because they choose not to set aside the observations of modern astronomy, certain words in Genesis 1 open a window into the dissonance created by such a rigid approach. Gadamer explored the ways that such an approach was sure to blur the actual meaning of an ancient text because of a lack of sensitivity on two important interpretive horizons - that of the interpreter and that of the ancient writer. My conclusions concerning the essential features of this hermeneutic approach will be summarized as being driven by three main features: literalism, selectivity, and closure.

First, as Brian Malley has shown, literalism is a term that serves more as an identity marker than as a systematic approach to interpretation. ${ }^{262}$ The word "literal" arises due to the emphasis put on the truthfulness of the Bible. Susan Harding has identified this tendency as well. "The interpretive tradition is literalist in the sense that it presumes the Bible to be true and literally God's Word, but the interpretive practices are not simply literalist." At the CM, interpreting the Bible as literally as possible is more of a simplification process than an interpretive method. I have observed many non-literal interpretations of the Bible. For example, God's anthropomorphic "resting" on the

${ }^{262}$ Brian Malley, How the Bible Works: An Anthropological Study of Evangelical Biblicism (Lanham, MD: AltaMira Press, 2004), $87 \mathrm{ff}$. For the best concise summary of literalist features of Bible reading, see James S. Bielo, Words Upon the Word: An Ethnography of Evangelical Group Bible Study (New York: New York University Press, 2009), 49-50. 
seventh day is non-literal. Repeatedly, the appeal is made to the genre of poetry to escape "literalism" in many passages that are troubling to YECs. ${ }^{263}$

Dissonance arises when someone attempts to apply a strictly literal approach to reading the Bible. One cannot get beyond verse two of Genesis 1 with a literal interpretation. In teaching introduction to the Hebrew scriptures, I have done an experiment with my classes in which I tell them to read the first few verses of Genesis 1 and then I will draw what they tell me the meaning is on the whiteboard in an effort to visually interpret the meaning. Inevitably, when they begin to describe the earth as "formless and empty," I ask them how I can possible draw something on the board that is "formless." I have noticed that some students become immediately uncomfortable. This tension is the dissonance that occurs when one realizes the conceptual difficulties of interpretation.

Because there is no way to read a document such as the Bible in a totally literal ${ }^{264}$ way, CM proponents are forced to maintain selectivity in certain parts of the Bible-even in Genesis 1. This fact came up with respect to the interpretation of the Hebrew word Rakia'. I never got an actual definitive answer to my question concerning what the Rakia' actually is. The best they could do was to say what the two best possible theories were: that Rakia' was the atmosphere, or that it was deep space. In either definition, figurative interpretation encroached-i.e. the sun could not literally be in the atmosphere and heavenly waters beyond deep space is as near to impossible an idea as anything I can conjure. As quoted in Chapter III, James Barr has described this alterative process by

${ }^{263}$ Notable examples are Job 37:18 with the sky described as "hard as a molten mirror" or Psalm 104:1-4 in which God is described as making the clouds into chariots and riding on the "wings of the winds" (New Revised Standard Version).

${ }^{264}$ By "literal" here, I mean that there would be no figurative or metaphorical senses contained in any verses of the Bible. 
fundamentalists: "In order to avoid imputing error to the Bible, fundamentalists twist and turn back and forward between literal and non-literal interpretation.,"265

Selective literalism is the result of having to explain the biblical text in such a way as to conform to what we now perceive about the world and the cosmos. Driven by a desire to maintain the absolute accuracy of the Bible — scientifically and historically — a certain closure occurs. Meaning is limited to the demands placed on the text by such doctrinal commitments as inspiration and inerrancy. Also called "concordism," forcing a modern view of the world onto an ancient document closes the possible meanings that the text could have had to its original audience and throughout the history of its interpretation. The CM's closed approach to hermeneutics results in the rejection of several fields of biblical criticism. Comparative literature and linguistics, source and redaction criticism, form criticism, and historical criticism are all rejected as corruptions of the Bible.

With the rejection of a vast amount of scholarship comes a narrowing set of prejudices that are projected on to an ancient document. This set of prejudices limits the types of questions that one asks of both the ancient text and one's modern perceptions of the world and universe. The limitation is caused by assuming that what the text says must conform to reality of the observable world currently. ${ }^{266}$ Therefore, openness through the process of questioning — the best practice of hermeneutics — is nonexistent. Gadamer insists that asking good questions is among the most important aspects of sound

265 James Barr, Fundamentalism (1977; repr., London: SCM Press, 1981), 40.

${ }^{266}$ I find it ironic that the CM insists on reading the Bible through modern lenses, but also criticizes modern science for always changing theoretical models. The irony comes in their use of distances and observable phenomena that come from the Big Bang paradigm. Thus, if science comes up with a replacement or major adjustment to this paradigm, then the CM will have to scramble to make the text fit that new model. 
hermeneutics. "The essence of the question is to open up possibilities and keep them open."267

The CM's approach convinces many people because they lack good translations as well as introductory materials to ancient cosmogony. The bulk of Genesis 1 deals in terms that people accept on a common sense level. The existence of plants, animals, the oceans, the sun, moon, and stars, all things said to be created, are what they appear to be to modern eyes. Mistranslations of words like Rakia' into nebulous concepts such as "expanse" helps to conceal the original meaning, doubling the hermeneutical task, to borrow Gadamer's phrase. In many cases, such as Genesis 1, competent interpretation requires a counterintuitive approach to reading the text. Lacking the study of biblical criticism, especially ancient epigraphy and cosmogony, the author's horizon remains closed for modern eyes. Such closure is exactly what Gadamer predicted should such modern prejudices go unquestioned. "But the basic prejudices are not easily dislodged and protect themselves by claiming self-evident certainty for themselves, or even by posing as supposed freedom from all prejudice and thereby securing their acceptance.”268

My research on how a closed hermeneutic works at the CM has shown a complex set of features that often contradict one another. First, this hermeneutic approach has been called "literalism." However, as Crapanzano has pointed out, there is a set of ten features that tend to accompany these so-called literalist approaches. ${ }^{269}$ While I have observed nearly all of these ten features at various points in the museum (literature, videos,

\footnotetext{
${ }^{267}$ Gadamer, Truth and Method, 298.

${ }^{268}$ Gadamer, Philosophical Hermeneutics, 92.

${ }^{269}$ Cited on page 42 in Chapter III, Crapanzano's list of ten features are found in Serving the
} Word, 2-3. 
exhibits, lectures), one feature not identified by Crapanzano is the most important for YECs. That feature is concordism.

The tendency to read scripture with categories of modern understanding is especially important for fundamentalists. As Denis Lamoureux has communicated to me, "It's [concordism] rooted deeply in our epistemological category of correspondence."270

Crapanzano's list of features are used by the CM in a piecemeal way, in order to support whatever interpretation suits the topic at hand. But the hermeneutic issue that drives everything else is this imposition of modern scientific categories onto the text. ${ }^{271}$ This imposition of some modern scientific categories is taken for granted. Due to the CM's particular commitment to the doctrine of inerrancy, all forms of understanding, or the truest articulations of reality as we know it, must somehow be present in the ancient text. When dissonance occurs, such as the attempts to describe the firmament or explaining how plants could grow without sunlight, the informants retreated in a couple of different directions. First, they began to use highly theoretical hypotheses, like Faulkner's positing water beyond the universe. The second direction was to default to the miraculous, such as when Mortenson indexed the miracles of Jesus to say that, in essence, whatever is problematic with our explanation can be solved through the appeal to God's power to do

${ }^{270}$ Denis Lamoureux, e-mail message to author, September 5, 2008. Lamoureux also responded to my suggestion that concordism could be thought of as a type of hermeneutic. "And though YECs are wrong, you're right on how wide spread concordism is, and it could legitimately be called a hermeneutical system."- e-mail message to author, December 8, 2008. I hesitate to use the word "system" because the CM has never used the term, to my knowledge. Nor is their use of concordism systematically thought out in a detailed and careful way. Rather, it is used inconsistently to suit their agenda. Moreover, scholars who do use the term, do so pejoratively to describe a fallacious hermeneutic practice.

${ }^{271}$ I am planning a full article on the highly selective use of some science-i.e. the distances of stars in Big Bang cosmology — but the neglect of others, such as the geologic time scale or radio metric dating. What a concordist hermeneutic does is to use any form of science that can be forced into the text, like saying that the "kinds" of animals noted in Genesis 1 refers to a modern family, genus, or species. But something radically different than what is at literal or face-value in Genesis 1, such as the millions of years of evolutionary change from simple to complex organisms, must be rejected at all costs due to inerrancy. So it is a highly selective use of some science on one hand, and the selective use of literal terms on the other. This is why the word Rakia' gives them so much trouble. It simply cannot be dealt with literally. 
anything. An interesting result was that conflicting data did not matter. The precommitments or prejudices assumed as all important are relatively few: a young, sixthousand year old universe; the Bible as an accurate scientific and historic account of human and natural history; and that evolution never occurred.

In the following chapters, I will attempt to show how these tightly interwoven hermeneutic premises are transmitted to diverse and numerous groups of religious visitors. The CM's attempts at solving evil and redefining science both involve the continued selectively literal interpretation of the primeval narratives of Genesis 1-11. Frames of authority and the screening of information become effective ways in which the CM guides its visitors toward a dualistic and anti-evolutionary interpretation of the world as seen through the lens of the Bible. 


\section{CHAPTER IV}

\section{EVIL EXPLAINED: THE CAUSE AND SOLUTION TO CORRUPTION}

This chapter will explore the ways that the CM explains why the world is an evil and corrupt place. It also proposes a solution for this corruption. Norman Fairclough's Language and Power provides a helpful vocabulary to describe the linguistic structure as it is used in the museum's exhibits, lectures, and audio-video materials. Because Fairclough deals with the discursive ways in which people use language as a means of power, I suggest that this approach is sufficient to map-out the ways in which controlling measures are mediated at the CM. As explained in Chapter II, I will apply two concepts from Fairclough's linguistic repertoire in analyzing the language at the CM. The first set of terms is schemata, frames, and scripts. The second group of terms involves how the museum fashions a cohesive worldview that people believe in through the use of connections between the Bible and the modern world. Fairclough calls this practice "coherence.",272

Because coherence is formed as a mixture of internal and external observations between the religious schema of an individual, a text, and making connections between the text and current events, the first section will begin by describing the religious schema as these include the internal intellectual and emotional commitments held by individuals. The first section, "The God/self/world Schema," will describe a religious viewpoint

${ }^{272}$ My intended application is explained at length on pages 49-63 (Chapter III) of this dissertation. Fairclough's definition of coherence may be found in Language and Power, $65 \mathrm{ff}$. 
necessary to make sense of the language used by the CM. Frames and scripts will be addressed as they appear in different spaces throughout the museum. The ways in which the language of the $\mathrm{CM}$ is used to form coherence will conclude each of the following sections: "Evil Narrated," "The Wonders of the Cell: A Lecture," and "Genesis: The Key to Reclaiming the Culture: A Sermon."

\section{The God/Self/World Schema}

As I will argue in my concluding chapter, the CM qualifies as an example of religious fundamentalism. Among other features of fundamentalist culture, the view of humanity as evil and the world as corrupt is central to their belief system. This idea of human depravity is closely tied to another feature of fundamentalism. That feature is dualism. Sometimes called "moral Manicheanism," dualism sees the world as sharply divided between the forces of God and good on one side, and the corrupted world and evil on the other. For dualists, there can be no neutral ground. Someone is either good (redeemed) or evil (unredeemed). ${ }^{273}$ Further, fundamentalists tend to assume that the world is getting worse- - hence the tendency to resist change. ${ }^{274}$

Telling the story of human disobedience is an important part of the operational logic used at the CM. In a recent article, Ham painted a bleak picture of how he views the state of affairs in current western culture. "As we look at our Western culture today, I

${ }^{273}$ As will be documented, Purdon (lecturer) and Ham (preacher) both use Matthew 12:30 to emphasize this dualism. They quote the citation of Jesus saying that someone is either for him or against him. This either/or duality is another central feature of the logic of fundamentalism.

${ }^{274}$ The shared properties of fundamentalist cultures are listed in: Gabriel A. Almond, R. Scott Appleby, and Emmanuel Sivan, Strong Religion: The Rise of Fundamentalisms Around the World (Chicago: The University of Chicago Press, 2003), 92-97. The two properties I mention here-dualism and a view that the world is getting worse - are just two of numerous family resemblances of fundamentalism on which I will elaborate in the conclusion. To be clear, the primary sign that the world is getting worse for fundamentalists is the rise of secular societies. 
believe in many ways what we see reminds us of the days of Noah." ${ }^{275}$ After listing what particular problems he sees in society, such as self-centeredness, homosexuality, abortion, nature worship, and undermining the authority of the Bible, Ham states: "The list goes on and on-truly we are in a time of great wickedness."276 The building block of the CM's explanation of the world is rooted in an extremely bleak picture of society, especially European and American society. One needs to be outraged before the extreme alternative solution for corruption is provided.

The problems of modern network society are so complex, that a dualist schema of God/self/world works well in attempting to explain how such immensely complex problems are really quite simple. ${ }^{277}$ While paradoxical, the reason why such an approach works is that, in a dualist schema, one can always retreat in one of two directions if the data of the observable world conflicts with one's presuppositions. For example, if science contradicts a biblical belief, then the dualist can always retreat to the supernatural realm of an omniscient and omnipotent God — one that can trump science at any point. If, on the other hand, the observation of the world seems to suggest that things are actually improving or getting better in the modern world, the dualist may insist this is just an evil deception. In other words, the unredeemed can never see reality for what it is because they lack the "true light" of God's redemptive revelation. ${ }^{278}$

${ }^{275}$ Ham is referring to the Noah narrative, beginning in Genesis 6. God was said to be angry with the great wickedness of mankind which precipitated Noah's flood. Ken Ham, "As in the Days of Noah," Answers 8 (Oct.-Dec. 2013), 35.

${ }^{276}$ Ibid., 35-36.

${ }^{277}$ The increasingly connected and globalized nature of world markets and information have actually provided fertile ground for the fundamentalist impulse-Manuel Castells, The Rise of Network Society, $2^{\text {nd }}$ ed. (West Sussex, UK: Wiley-Blackwell, 2010); and Olivier Roy, Holy Ignorance: When Religion and Culture Part Ways, trans. Ros Schwartz (New York: Columbia University Press, 2010).

${ }^{278}$ This may be illustrated with the cartoon image of a person looking through the lens of the Bible to see reality-Figure 2, page 53. Further, this belief is stated in the Answers in Genesis "Statement of Faith," Section 4: "By definition, no apparent, perceived or claimed evidence in any field, including history 
God is understood to exist in a category separate and transcendent from the corrupted world. In an article on the Answers in Genesis website, the following statement confirms this understanding: "We have seen that the Father, Son, and Holy Spirit are all the one infinite transcendent God. ${ }^{279}$ This gap between self/world and the transcendent domain of God serves to provide a space between true knowledge (God's knowledge) and human knowledge (knowledge that is tentative at best and tends toward error). Using this distinction enables the $\mathrm{CM}$ to insert doubt at various points of disharmony between actual observations of the physical world and the surface claims of the Bible. ${ }^{280}$ Thus, an appeal can always be made to the ultimate, unknowable answer that lies shrouded in the unreachable realm of God. The only link between these two epistemological realms is the revealed word of God. All that may be known of the physical realm must therefore be harmonized with the Bible, as they see it.

The category of self, in this schema, includes an anthropology also derived from their interpretation of the Bible. The only statement about humanity contained in the AIG "Statement of Faith" is the following: "All mankind are sinners, inherently from Adam and individually (by choice), and are therefore subject to God's wrath and condemnation." ${ }^{281}$ Here the CM views all people as jaded by sin. To some unspecified degree, the condition of sin corrupts the ability to interpret both the physical world and

and chronology, can be valid if it contradicts the scriptural record. Of primary importance is the fact that evidence is always subject to interpretation by fallible people who do not possess all information." Answers in Genesis, http://www.answersingenesis.org/about/faith (accessed November 13, 2013).

279 Dr. Mark Bird, "The Trinity," Answers in Genesis, http://www.answersingenesis.org/ articles/aid/v3/n1/the-trinity (accessed November 13, 2013).

${ }^{280}$ In many ways, this dichotomy hearkens back to the Patristic period which was heavily influenced by Platonic categories. Platonism dominated scholastic Christian theology from the third century until the early medieval period - see Justo L. González, The Story of Christianity: The Early Church to the Dawn of the Reformation vol. 1 (New York: HarperCollins, 1984), 315-16. It is my assessment that the Platonic impulse (dualism) lives on in most fundamentalist cultures.

${ }^{281}$ Answers in Genesis, http://www.answersingenesis.org/about/faith (accessed November 13, 2013). 
the Bible. To see and interpret clearly requires the help of God. Ham explains this view

of the corrupted self:

Thus, it is God who lets us see the truth-lets us see that the evidence is all there - that He is Creator. However, in a very real sense, there has to be a willingness on our part to want to see as well. Why can the humanists, the evolutionists, not see that all the evidence supports exactly what the Bible says? It is because they do not want to see it. It is not because the evidence is not there. They refuse to allow the evidence to be correctly interpreted in the light of biblical teaching. ${ }^{282}$

Such a description is quite helpful in explaining any and all contradictory evidence. For if scientific data opposes the CM's interpretation, they are said to be either blinded by their own unrepentant sin or are not reading the Bible in the correct way. So this view of the human self as corrupted serves as the answer to any point of view that disagrees with the $\mathrm{CM}-$ Christian or non-Christian. ${ }^{283}$ If a viewpoint fails to align with that of the CM, then either one is reading the Bible the wrong way or that person is blinded to such a viewpoint because of their sin.

The category of world in this schema is closely connected to that of the self. In fact, because humanity is part of the world, it is exceedingly difficult for CM advocates to delineate where self ends and world begins. ${ }^{284}$ However, the basic premise that drives the theological understanding of the world is that it, like humanity, has been corrupted by sin. The following statement describes this state of affairs. "Death (both physical and

${ }^{282}$ Ham, The Lie, 75-6.

${ }^{283}$ A further nuance of their view of the self is that people who are non-Christians are completely unable to discern truth. This assertion is not consistently demonstrated, as I have previously noted on page 96. And the accusation only applies to certain realms of knowledge - i.e. "origin" science and interpretation of the Bible, rather than to subjects such as mathematics and chemistry.

${ }^{284}$ The typical feature in a dualist Christian schema that bridges the transcendent gap between God and self and delineates the difference from self and world is that of the role played by the Holy Spirit. God's Spirit mystically enlightens, saves, and allows for the transcendental gulf to be crossed. While the $\mathrm{CM}$ does not contain a lengthy, nor systematic treatment of theology proper, the following statements from the AIG website insinuate this assertion. "The Holy Spirit enables the sinner to repent and believe in Jesus Christ. The Holy Spirit lives and works in each believer to produce the fruits of righteousness." Answers in Genesis, http://www.answersingenesis.org/about/faith (accessed November 13, 2013). 
spiritual) and bloodshed entered into this world subsequent to and as a direct

consequence of man's sin. ${ }^{285}$ What this means is that physical evil (natural occurrences) and moral evil (acts of human volition) have impacted every aspect of life. Described in a CM publication:

When Adam sinned, however, the Lord cursed the universe. In essence there was a change, and along with that change God began to uphold the creation in a cursed state. Suffering and death entered into His creation. The whole universe now suffers from the effects of $\sin$ (Romans 8:22). ${ }^{286}$

God's "cursing the universe" resulted in a strange set of effects. These "effects of sin" include visible reality. For example, the stars are so far away that it requires millions of years for starlight to reach the earth. But because this could not be so, given a sixthousand year limit, the $\mathrm{CM}$ asserts that things were created with "the appearance of age." In other words, the stars are indeed as far away as Big Bang cosmologists claim, so light must either be capable of travelling much faster than we currently understand or God miraculously created all of the light-waves while making them look older than they really are.

The God/self/world schema attributes all of the pejorative happenings in the world as derivative from the literal account of Adam and Eve eating a forbidden fruit in Eden. The result of the fall is a world and self that are unreliable in determining what happened in the past. The world contains features that have to be reinterpreted though the corrective "lens" of the Bible. The reason that this also includes the physical sciences is because the equally corrupted human self unreliably interprets physical data toward ungodly ends. The only way to break out of this circular dilemma is through the divine

\footnotetext{
${ }^{285}$ Answers in Genesis, http://www.answersingenesis.org/about/faith (accessed November 13, 2013).

${ }^{286}$ Ken Ham ed. The New Answers Book, vol. 1 (Green Forest, AR: Master Books, 2009), 330.
} 
light of God's spiritual transformation — salvation. Once more, Ham offers the only epistemological way forward: "If we want to come to right conclusions about anything, the only sure way is to start with the word of the one who has absolute knowledge. We Christians must build all of our thinking in every area on the Bible.,287

Circularity inevitably results as only those who have been fully redeemed see the correct interpretation as the $\mathrm{CM}$ does. Any disagreement with the official position of the $\mathrm{CM}$ is either a sign of total unbelief or a sign that one, even though redeemed, still lacks the requisite faith to believe the Bible in a strictly literal sense. The CM's answer to the problem of evil begins with a summons to read the primeval narratives of Genesis (Chapters 1-11) as historically accurate accounts detailing exactly how sin was caused by and became a problem for humanity. Connected closely to the cause of sin, the CM also offers a solution that would reclaim culture in such a way as to restore a better and more godly society.

\section{Coherence}

As Fairclough has noted, frames, scripts, and schemata all work together to form a "highly complex network of mental representations." ${ }^{\text {288 }}$ Three of the frames occurring at the CM are the museum's main exhibit, the lecture hall, and the pulpit. These frames are traditionally seen as places of authority in western culture. While they usually deal with different domains of knowledge (most typically that of museums with a particular type of artifact, lecture halls with the university or scholarship, and the pulpit with the religious

${ }^{287}$ Ham, The Lie, 56.

${ }^{288}$ Fairclough, Language and Power, 132. Fairclough uses schemata (plural) for a number of different mental representations - political, economic, religious, etc. I use schema (singular) to describe just the religious mental representations of much Christian fundamentalism. 
sphere) these three settings form a natural platform for authoritative voices, or scripts, to speak to a mostly lay or student audience. These scripts function on two levels at the CM: the authoritative script (the lecturer, biblical expositor, scientist) and the lay or student script (the average visitor).

The linguistic dynamic at work is a complex set of connections, usually by the authoritative voices, between the person's religious schema and observations from the biblical text and from text to the current observable world. The term "authority" is repeatedly and explicitly foregrounded throughout the museum. The answer to the subject of this chapter, the solution to corruption, is that society must return to the ultimate authority of the Bible.

\section{$\underline{\text { Evil Explained - Biblical Authority, Graffiti Alley, and Culture in Crisis }}$}

The CM seeks foremost to be a point of absolute certainty for those in need of moral and epistemological absolutes. As discussed in Chapter III, the source of all absolutes are said to reside in the infallible and inerrant Word of God. An epistemological choice is offered in the first three rooms of the main exhibit-Slot Canyon, Dig Site, and Starting Points. The choice is either the shaky and uncertain opinions of humanity or the solid and certain words of God. The most negative imagery in the museum takes place in the three rooms discussed in this section. My research has led me to the conclusion that this series of exhibits are the most emotionally charged and persuasive forms of argumentation at the $\mathrm{CM}{ }^{289}$

${ }^{289}$ First, I would note that the persuasion only takes place for those who are deeply committed to both biblical inerrancy and/or anti-evolutionary viewpoints. Most of the time, these two views are linked closely together. Second, my study of reactions by several scholars (not committed to the CM's premises) has shown that Graffiti Alley and Culture in Crisis is both deeply offensive and emotionally disturbing. 
As the visitor leaves the Starting Points room, a change occurs from a neutral setting of sophistication to an actual interpretive walk through Bible history. When I asked the designer of the CM, Patrick Marsh, what type of museum he thought the CM was (i.e. museum of anthropology, natural history, art, etc.), he gave a very long answer and basically laid-out the philosophy that he and Ham came up with. I include almost all of Marsh's answer below because it is the best description of the internal logic and planning of the CM that I received in any of my numerous interviews. Also, many aspects of how the museum serves as a types of frame emerges as he fields my question. $^{290}$

Me: How would you classify the Creation Museum-i.e. Museum of Anthropology, Natural History, Art, etc.?

Marsh: Here's how the museum came about and this is how I approach everything. First of all it's all true. And so we start with that. And the second thing, I asked Ken Ham to write a script to define what it is he wanted to teach as a museum. So it is a teaching museum, it has a very specific goal in mind. I mean not, not that other museums don't have a goal. Their goal is evolution but they can sort of walk you all over the place with whatever is the evidence that they think they have. Our goal was to teach you about creation. It's all based upon Ken Ham's Creation, Corruption, Confusion, Catastrophe, Christ, Cross, and Consummation. That's the basis of everything he teaches. That's the basis of the museum. So I said, "Write down a script." Because he said, "how could we create a museum since we don't have any artifacts?" And I said, "You don't need artifacts, we are going to tell a story." Now it's not a story, it's history, but we're gonna tell it in a historical fashion and we're going to take my theme park experience and put it together so that we create these scenes where people can go through and kind of get into the experience of it so it's not just the sterile, you know, museum of artifacts it really is an experiential thing. I wanted it to be experiential. I also knew that people don't read today, they watch TV, you know...it's like I used to call it the MTV generation. So whatever we said it had to be short clips, it had to be in film, it had to be done dynamically, we had to use

One other room titled Cave of Sorrows - located later in the museum — is equally negative and disturbing. Barton, Pray the Gay Away, 167.

${ }^{290}$ Patrick Marsh is the Design Director of the CM. He is the artistic mind behind how the CM became what it is visually. Marsh formerly worked for Universal Studios and was a key designer of the Jaws and King Kong exhibits for that theme park. In my estimation, the reason for the success of the CM is due mostly to Marsh's talent and ingenuity. Marsh gave incredibly lengthy answers to my questions. 
animatronics, we had to use all the techniques that get people excited about a theme park. So that was the big basis of my starting. I said if you want to reach the younger generation and if you want to reach the population, you have to speak to them on the level they're used to. Go to Disneyland, look at it, that's where everybody gets excited. That's where to me all the other creation museums have gone awry because they haven't...they haven't stepped out that far. You know, they're still kind of in their science mode in a way - and God bless them for what they've done - but they're evidential. We are not evidential. What we do is take and walk you through the scripture. And that's ultimately what it is. We're just saying "this is what the Bible says, this is what the scene is like, this is what the time is like and kind of put you in the middle of that whole thing as you walk through the museum." I mean we started in the very beginning with a museum to show you that literally, if you weren't there, how do you know what the truth is? Uh, and we give you examples of things, we start in the very beginning to walk you through the Grand Canyon and to show you that Mt. St. Helens was a perfect example of how a canyon could be formed in short order. I mean it did exactly the same thing that the Grand Canyon did, you know, just almost overnight. And then we take you into the dinosaur dig and we show you that the bones don't come with labels. We know that people have all these different techniques of trying to figure out how old something is, but they're not a hundred percent accurate and they work within the rock or whatever and when you start to examine those kinds of things and you find, you know on the top of the Grand Canyon, you know rocks that are supposedly millions of years old and on the bottom of the Grand Canyon some that are only thousands of years old, you get this discrepancy that doesn't make any sense. And so those are the kinds of things that we are trying to tell people that dinosaur bones don't come with labels on them. And we move you into the next section which really talks about the fact that everybody starts with the same evidence and so it really is your point of view. Do you have a biblical point of view or do you have a secular point of view? And however you do, that's how you are going to look at the evidence and interpret it. So from there we walk you through biblical history. We start with, what do the patriarchs say? And then we teach you that no matter what has happened in history, that if the Bible said a certain place existed and we haven't found it yet, eventually it's found and the Bible is exonerated, right? And the same thing with people who constantly try to disprove that the Bible is true, it's always been able to be proven that it is true. You know historically, scientifically, everything else. It's not a science textbook, as Ken [Ham] will say, but it basically teaches you about all of these things. And so that's the way that we wanted to present this. We took all of the contemporary elements, you know, film, great graphics, and animatronics and what have you, and special effects and things and tried to create a presentation for people to help them kind of get into it. And begin to see the Bible as real. As truth.

Marsh's description is clear in presenting the viewpoint that the message of the $\mathrm{CM}$ reflects the truest aspects of history that has ever been attempted by a museum. In 
this sense, the CM is seen by its advocates as the "ultimate museum"- a place where all competing narratives are put in their proper place. Since natural history museums have been corrupted because they accept the scientific consensus on evolution, the CM provides the alternative to knowing everything about life on planet earth because only they begin with the real, rather than the corrupt, story. Marsh makes this point by his short statement above: "First of all it's all true." Like Ham and the other supporters committed to inerrancy, the $\mathrm{CM}$ is presented as the most absolute, authoritative voice anywhere. It simply walks the visitor through history as it really happened. While Marsh never explicitly answered my question - the closest he came was his response that it was "a teaching museum." The content of the museum is an interpretive walk through the Bible as Marsh described: "What we do is take and walk you through the scripture.",291 Other informants to whom I posed this same question- - How would you classify the Creation Museum? - gave similar answers as that of Marsh. Bodie Hodge responded to this same question with the following response: ${ }^{292}$

Hodge: Well this is a unique museum, you know? It doesn't fit into a classical norm. When I was over in Sweden, we had, there were museums of all different sorts. You know, you can go to just different ones on phones, or something. This is unique in that it is a biblical authority museum. It looks at a walkthrough of the Bible. For example, as a creation museum - so we focus specifically on the history in the Bible, specifically around creation. ... There are natural history museums out there. And what they've done is that they've split apart things. You know? You have the natural and you have the supernatural, where God is the God of both the natural and the supernatural.

\footnotetext{
${ }^{291}$ When I first began researching the CM in 2008, I was skeptical about the level to which advocates of the CM, especially the leaders like Ken Ham, Mark Looy, Patrick Marsh, et. al., actually believed their espoused position. At this point in my research, I am convinced that they believe it onehundred percent.

${ }^{292}$ Bodie Hodge is a full time staff member at the CM and holds the title "Speaker, Writer, Researcher." Hodge holds a B.A. and M.A. in mechanical engineering from Southern Illinois University (Carbondale).
} 
Hodge, similar to Marsh, also perceived the CM to be a "walkthrough of the Bible." Hodge was the only informant to describe the CM as a "biblical authority museum." However, this is a helpful way to describe the intent and purpose of the museum both as conceived by Ham and deigned by Marsh.

Museums — institutions with a wide range of meanings ${ }^{293}$ — are powerful cultural institutions in that they are typically viewed as institutions which provide scholarly consensus on a collection of artifacts. Moreover, they aim to educate a largely lay audience. Mainstream museums (such as publicly sponsored museums of natural history, history, art, and science) also include departments of research. ${ }^{294}$ These collections of artifacts are researched by specialists from the academy in efforts to discover new information in a variety of fields. Thus, the museum is appropriated as an authoritative frame by advocates of the CM. ${ }^{295}$

Scripts consist of the "voices of authority" carried out by the staff members and experts that lead visitors to the CM's viewpoint. The frame of the museum carries an authoritative weight all its own and its validity as a museum is usually not questioned by average visitors. There are virtually no discussions of what actually constitutes a museum and/or if the CM qualifies as such. Julie Duncan has accurately described the reason for

${ }^{293}$ For the breadth of definitions offered for the term "museum," and the categories of classification of museums, see: Timothy Ambrose and Crispin Paine, eds. Museum Basics ${ }^{\text {rd }}$. ed. (New York: Routledge, 2012), 1-19. Stephen E. Weil also discusses the enormous amount of variety and change that museums have undergone in the twentieth and twenty-first centuries: see especially Chapter 3, "From being about Something to Being for Somebody: The Ongoing Transformation of the American Museum," in Making Museums Matter (Washington DC: Smithsonian Books, 2002), 28-52.

${ }^{294}$ The above qualifications for museums are taken from the following sources: The International Council of Museums (ICOM) defines a museum in the following way- "A museum is a non-profit, permanent institution in the service of society and its development, open to the public, which acquires, conserves, researches, communicates and exhibits the tangible and intangible heritage of humanity and its environment for the purposes of education, study and enjoyment." International Council of Museums, http://icom.museum/the-vision/museum-definition/ (accessed 19 November, 2013).

${ }^{295}$ I will return to the concept of a museum as a place of authority in Chapter V- "Science Redefined: Why a Museum?" Here, I mention the general concept as the museum serves as the overarching frame for the voices of authority (scripts) to weigh-in as experts. 
using the museum as the primary designator. "By calling their institutions museums instead of 'Bible centers' or 'Faith parks,' then, creationists automatically appropriate for their institutions this reputation for credibility and education." ${ }^{296}$ So the frame of "the museum" helps the messages presented to appear credible. Hodge's title of the CM as a "biblical authority museum" is the appropriate classification for exactly what Marsh and Ham have sought to provide.

As the visitor leaves Starting Points and enters the Biblical Authority room, an argument begins to develop. In sum, the argument that is presented in the next three rooms is stated explicitly in a CM publication: "When Christians and Christian families no longer promote the absolute authority of God's Word, they reap the consequences in the next generation. ${ }^{, 297}$ Described in the Appendix A, the Biblical Authority room seeks to establish that the Bible has been proven to be accurate as an historical and scientific source. Concerning the Biblical Authority room it is clearly stated that: "Throughout the Creation Museum, observational science (biology, geology, etc.) is used to confirm that the Bible's history truly explains the world. This room [Biblical Authority] gives examples of witnesses down through the ages who attest to the truthfulness of God's Word.",298

The actual script present in Biblical Authority is the Bible itself, presented as the perfect and flawless historical record. The Bible — as the word from God — is the highest form of earthly authority because God is seen as the ultimate and supreme being. The

\footnotetext{
${ }^{296}$ Duncan deals with four different YEC museums around the United States but does include the $\mathrm{CM}$ as one of these. Julie Anne Duncan, "Faith Displayed as Science: The Role of the 'Creation Museum' in the Modern American Creationist Movement” (honors thesis, Harvard University, 2009), 122.

${ }^{297}$ Answers in Genesis, Journey Through the Creation Museum: Prepare to Believe (Green Forest, AR: Master Books, 2008), 35.

${ }^{298}$ Ibid., 31.
} 
Biblical Authority room is framed as a walk through Bible history. It begins with mannequins fashioned as a select few of the more famous prophets (Moses, David, Isaiah, and Paul) as witnesses who are said to "attest to the truthfulness of God's Word. ${ }^{299}$ Moses is shown holding a set of stone tablets with the Ten Commandments written on the tablets in Hebrew. ${ }^{300}$ The mannequin portraying Isaiah presents a white bearded man holding two large scrolls bounded together with leather straps. The apostle Paul is seated at a desk with an ink pen in hand as he is depicted as writing in uncial Greek on a papyrus sheet. ${ }^{301}$ These Bible prophets and the Apostle Paul assume the script of human authorities. They are presented as divinely authorized mediators who deliver words of God to the human race.

After the prophetic mannequins, a lengthy display board presents several historical attacks on God's word. These are said to be periods of time when humans were skeptical and questioned God's revealed word. Interestingly, one point of attack that is repeated in numerous places is Adam and Eve's questioning of God in the Garden of Eden. Referring to these attacks, a CM source explains:

The sign on the far wall of the Biblical Authority Room illustrates how God's Word has been under attack since the temptation of Adam and Eve in the Garden of Eden. Today's teaching that history goes back millions of years is just the latest

${ }^{299}$ Ibid.

${ }^{300}$ Interestingly, the Hebrew script used on the tablets is the much later block Aramaic script. This is an anachronistic error as the ancient Hebrew language - if it could even be called "Hebrew" - was written in a paleo-Hebrew script that was likely more tied to an indigenous Canaanite dialect. The point is that, even assuming Moses actually wrote Exodus, it would have appeared as a much earlier paleo-Hebrew script. The CM has no Hebrew scholars on staff.

${ }^{301}$ Uncial (or all capital letters) Greek was a form found in the prestigious $4^{\text {th }}$ and $5^{\text {th }}$ century codices, including Codices Sinaiticus, Vaticanus, and Alexandrinus. It is highly questionable as to whether Paul would have written in an uncial form. More likely, he would have employed a lower-case, cursive script style of Koine Greek (Bruce M. Metzger, The Text of the New Testament: Its Transmission, Corruption, and Restoration $3^{\text {rd }}$ enlarged ed. [Oxford: Oxford University Press, 1992], 9). Moreover, biblical textual critics have been inclined toward the position that Paul used an amanuensis (a copyist) to whom he dictated the words to be written. 
attack on the authority of God's Word, which says God created everything a few thousand years ago. ${ }^{302}$

Taking the Eden account as an actual historic event, the CM asserts an important premise: The cause of all forms of evil (moral and physical) originally derived from the transgression to believe the serpent who said to Eve, "Did God say, 'You shall not eat from any tree in the garden?", ${ }^{303}$ Ham and those at the CM have formed an interesting connection between the temptation in Eden and evolution.

As is clear from the CM source quoted above, any attack on the authority of God's word is linked to this original sin that brought down the human race. An entire explanatory theology emerges which asserts the serpent in the Genesis 3 account with Satan or the Devil. Ham has always linked the serpent and Eve with Satan and an attack on God's word. He describes this connection: "The first attack was on the Word of God. Satan's method was to cause Eve and Adam to doubt the Word of God, so that doubt

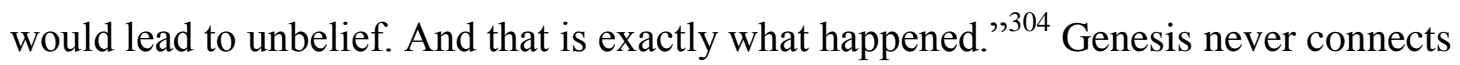
the serpent with the idea of Satan or the Devil as developed later in Jewish and Christian history. But Ham is able, through texts, sermons, and visual imagery, to seamlessly assert the idea that the serpent was simply a form that a supernatural Satanic being inhabited.

An example of how he uses imagery may be seen in two different editions of the cover of his most popular book, The Lie (see Figure 5, below). Notice that the forbidden fruit is represented as the popular idea of an apple. ${ }^{305}$ In the 2001 edition, the cover is

302 Journey Through the Creation Museum, 32.

${ }^{303}$ Genesis 3:1 (New Revised Standard Version).

${ }^{304}$ Ham, The Lie, 24.

305 There is no mention in Genesis of any specific type of fruit on the Tree of the Knowledge of Good and Evil. While CM sources note that the type of fruit is not mentioned in Genesis, two types are represented at the CM in the exhibit and in print publications (Becky Stelzer, Stacia McKeever, Roger Patterson, and Gary Vaterlaus eds.,The Creation Museum: Behind the Scenes [Hebron, KY: Answers in Genesis, 2008],81). Those two fruits are an apple and a cluster of grapes. See the following essay for a 
changed to present the earth in the shape of an apple with a bite taken out of the top left corner. Ham is able to pull off an incredibly influential link between the epic scene in the Garden of Eden and the teaching of evolution. He casts the entire effort of the CM as the most important issue of the day because it is parallel to the one sin that brought down humanity-in the Fall.

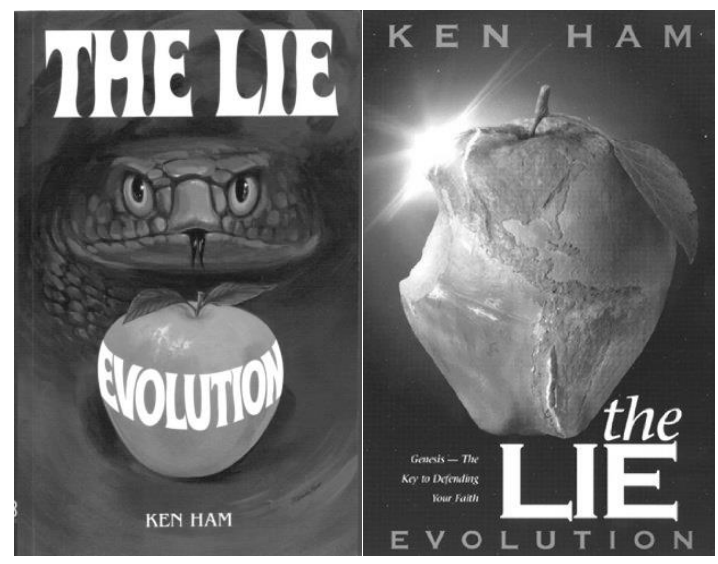

Figure 6. Above are the covers to the first (left - 1987) and second (right - 2001) editions of Ken Ham's book The Lie (Green Forest, AR: Master Books).

Ham achieves an important link in aligning evolution with the fall of humanity.

The cure for corruption (eradicating evolutionary teaching) has been linked to the cause of corruption (disobeying God by eating the forbidden fruit). He makes this connection explicit by presenting both the fall in the garden and evolutionary science as attacks on God's word.

This attack has continued unabated since Genesis 3. The Genesis 3 attacks have continued down through the ages. However, these attacks have manifested in different ways in different eras of history. ... We need to be asking ourselves a question: What is the Genesis 3 attack in our era of history? ... I believe the teaching of evolution and millions of years is that attack. ${ }^{306}$

fuller discussion of the exhibit: Steve Watkins, "Dragon Snakes and Fictitious Fruit: What Happens When Myths are Literalized," The Fourth R: An Advocate for Religious Literacy 26 (March-April 2013): 6-8.

${ }^{306}$ Ham, The Lie, 24 [emphasis mine]. 
Convincing people that evolutionary theory is a Satanic attack on God is a powerful emotional motivator for those who accept the premise. ${ }^{307}$ Such an assertion also implies why the literal Garden of Eden account becomes so important for YEC's. All evil had a historical beginning with the epochal event of Eve's doubting the word of God. Such doubt brought about the curse of God and original sin for all of the human race. Doubt about the literal word of God is presented as the worst kind of sin because it is a form of unbelief. Unbelief is what separates the redeemed from the unredeemed - the good from the evil.

In the Biblical Authority room, doubting the revelation of God is indexed throughout history as the ultimate struggle between good and evil. Moreover, any time the Bible is said to be "under attack," it is a sure sign that the forces of evil are organizing the effort.

The God/self/world schema of dualism relates well to ideas of Satanic attacks against the people of God. Thus, the Biblical Authority room selectively chooses times in western European history when Christianity has been under attack. Chapter One of Ham's book The Lie is titled, "Christianity is Under Massive Attack." ${ }^{\text {"308 }}$ The effort to present current American culture as being attacked once more by the forces of evil helps to establish solidarity among those who see themselves as on the side of God and good.

${ }^{307}$ While Genesis 3 contains no connection between Satan and the serpent, many Christians have adopted the view that Satan was in the Garden of Eden, having taken the corporeal form of a snake. CM materials make this connection, repeatedly. For example, referring to a passage from the Pauline epistle, 2 Corinthians 11:3, Ham writes: "Paul is warning us that Satan is going to use the same attack against us (and on our children, grandchildren, friends, family, and others) as he did against Eve to get us to a position of not believing the things of God." Ham, The Lie, 23. Later, Ham makes this connection again: "Evolution is a religion that enables people to justify writing their own rules. The sin of Adam was that he did not want to obey the rules God set but instead to do his own will. He rebelled against God, and we all suffer from this same sin: rebellion against the absolute authority. The evolution/millions of years belief has become the so-called scientific justification in today's world for people to continue in this rebellion against God," 69.

$$
{ }^{308} \text { Ibid., } 27 .
$$


The museum display boards chronicle how Christianity has been under attack throughout the ages. There are eight display boards which describe the various ways in which the Bible is attacked - seven of these propose the main ways in which the Bible (God's Word) is undermined through attempts to "Question," "Destroy," "Discredit," "Criticize," "Poison," and "Replace" the holy text. ${ }^{309}$

The opening display board, "The First Attack to Question God's Word," attempts to delineate the realms of good and evil. A face value literalism is shown to be the only way to read God's word, just as Eve and Adam fell into sin by not accepting the literal, face-value warning God gave them to abstain from eating the forbidden fruit. Their sin is not merely seen as the act of eating the fruit, but more importantly, the "bigger" sin is doubt that undermines a simple trust in any proposition in the Bible. Following this premise, anyone who questions or doubts such a literal style of interpretation is placed on the side of the serpent of Genesis $3 .{ }^{310}$ For CM advocates, the high crime is doubting the Bible which is the same as doubting God.

The Biblical Authority room presents a sweeping historical account of the times

${ }^{309}$ The first display board is titled "The First Attack to Question God's Word." The text reads: "Adam believed God's word. God said, 'Eat of the fruit and you shall surely die.' Satan questioned it. 'Did God really say...?' 'You shall not surely die.' Humanity abandoned it. Adam ate the fruit and died." The summary statement of the display board reads: "In the Garden of Eden, the serpent questioned God's warning about death. He asked the first woman, 'Did God really say...?' The elevation of human reason above God's Word is the essence of every attack on God's Word." These quotes have been transcribed from a photo of the Biblical Authority room of the Creation Museum (December 2, 2013).

${ }^{310}$ Two points of clarification need to be made. First, it is obvious that the CM is dogmatic in asserting that their claim on interpretation is the only correct interpretation of Genesis. Thus, even other evangelical and fundamentalist Christian positions are categorically placed on the side of evil, since they question the supposed correct interpretation of the CM. Second, the serpent is presented as Satan-the ultimate source and cause of all evil. This may be seen in the second premise in the display board as recorded in Footnote 288 (above). "Satan questioned it. 'Did God really say...?' 'You shall not surely die." Notice that in this statement Satan is shown to be the interrogator in Genesis 3. The questions attributed to Satan are the verses in Genesis that are said to be the serpent's words (Genesis 3:1; 3:4). 
in human history when the Bible has been under attack. ${ }^{311}$ The following are examples from the display boards in the Biblical Authority room:

The Hebrews repeatedly introduced Idol worship, despite the commands of God's Word. So God sent idol worshippers to conquer the Hebrew people.

After the Jews were restored to Jerusalem, human traditions slowly twisted God's Word, changing its original intentions. Messiah Jesus condemned these traditions and was crucified for his efforts.

Genesis mentions the Hittite people. Historians found no evidence of these people outside the Bible, considering this an error. Then archaeologists discovered the enormous Hittite capital, Hattusa, in Turkey.

After Noah's Flood, nations twisted God's revealed history and developed alternative creation myths and religious rites. But one family - the Hebrew nation descended from Abraham - preserved God's Word for all future generations.

In the eighteenth-century Enlightenment, the infidel philosopher Voltaire forecast that within a century no Bibles would be left on earth. But fifty years after he died, the Geneva Bible Society took over his house and printing press to produce thousands of Bibles. ${ }^{312}$

The statements above present history as a struggle between the revelation of God (the Bible) and those human efforts to undermine, question, or destroy the Bible. Once this narrative is adopted, an important connection is made in which evolution is presented as the most recent such attack, as documented on page 149 (above). Christians are called on to join the $\mathrm{CM}$ effort to refute evolution and in so doing to simultaneously defend the revelation of God. This strategy presents the efforts of the CM as aligned with the many faithful people through history who have fought for God's word against the onslaughts of the enemy.

${ }^{311}$ I use "the Bible" as synonymous with "the Word of God," because that term is more specific than "the Word of God." The phrase "Word of God" is used more commonly in CM publications, but its overwhelming meaning is that of the canonical Christian, Protestant Bible (the CM regards the Apocrypha as non-canonical).

${ }^{312}$ The quotes are transcribed from photos taken of the display boards in the Biblical Authority room of the Creation Museum (December 2, 2013). 
The Biblical Authority room also presents a mannequin of Martin Luther as he nails his Ninety-Five Theses to the door of the Wittenburg castle (Photo 2). The piece of paper on the Wittenburg Door reads as follows:

Here I stand, I can do no other. If I profess with the loudest voice and clearest exposition every portion of the Word of God except precisely that little point which the world and the devil are at that moment attacking I am not confessing Christ, however boldly I may be professing Him. Where the battle rages, there the loyalty of the soldier is proved; and to be steady on the entire battle front besides is mere flight and disgrace if he flinches at that point. ${ }^{313}$

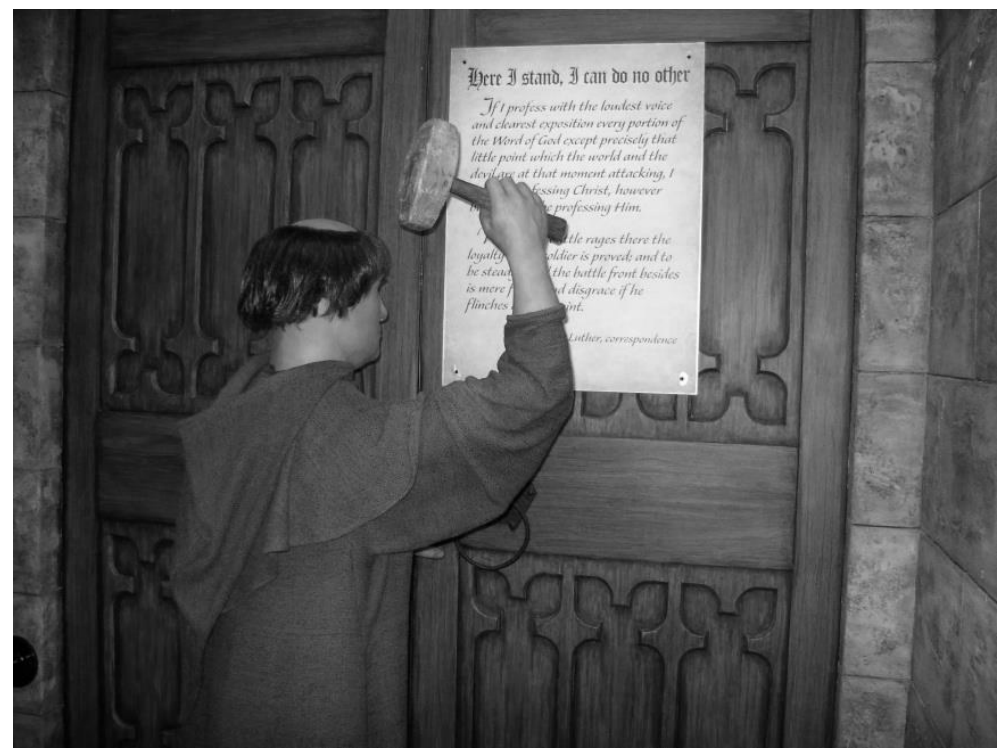

Photo 2. Martin Luther nailing a document to the Wittenburg Castle door. Photo: S. Watkins

Two parts of this quote are strategically placed to fit the narrative established in the display boards. First, Luther is presented as the Protestant hero who fought against the Roman hegemony which had corrupted the Bible by withholding vernacular translations

${ }^{313}$ Transcribed from Photo 2, taken in the Biblical authority room of the Creation Museum (December 2, 2013). I should note here that the document in the photo contains no part of the text from Luther's Ninety-Five Theses. In fact, the quote above contains only a few speculative phrases from Luther's actual words. These phrases come from an English translation of the German response that Luther gave at the Diet of Worms, Roland H. Bainton, Here I Stand: A Life of Martin Luther (New York: Abingdon Press, 1950), 181-86. The quote at the CM is an apocryphal assertion that cannot be located in any of Luther's translated works, William T. Iverson, Jesus and the Ways of Socrates: Human-Shaped Education for the Twenty-First Century (Bloomington, IN: Cross Books, 2012), 63. 
from the masses of Christians. Second, as is obvious in the statement above, the Word of God is viewed as under attack by "the world and the devil." The dualistic view of the Bible as under attack by the forces of evil repeats and continues the historical sense begun in the display boards.

The last major scene in the Biblical Authority room is a three dimensional representation of the courtroom in which the Scopes Trial occurred. As a last piece of history in the struggle between God's Word and man's word, the Scopes Trial is interpreted as the example of what happens when people do not read the Genesis account literally. An explanation is offered in a CM publication that describes the Scopes scene in the Biblical Authority room:

Scopes Trial Exhibit - The Scopes Trial in 1925 marked a turning point in American history. The world press saw that Christians and the church had compromised with the notion of millions of years, so Christians no longer had adequate answers to defend the Christian faith. ${ }^{314}$

The same theme is continued, but with the twist this time of how American history changed as a result of Christians having no options available to defend the Bible from the more recent attack of evolutionary theory. This is an interesting strategy as the CM implicitly indexes itself as the institution of rescue in such troubled times. It also appears before the most negative turn in the imagery and tone of the museum.

As the visitor leaves the Biblical Authority room, a change from the well-lit and inspiring history of the struggle between good and evil propels one into the corrupted world of modernity. The first of these exhibits is Graffiti Alley. This dark alley is made to look like an inner-city ghetto. Spray-paint appears on brick walls that line a black-topped street leading the visitor past broken windows and walls pasted with news clippings of

\footnotetext{
${ }^{314}$ Journey Through the Creation Museum, 33.
} 
school shootings, violence, and drug abuse. This negative imagery follows an implicit premise that the modern world is the worst of all times in human history. ${ }^{315}$ A view that the world is getting morally worse, linked with the advances of modernity, has always been a central premise of fundamentalism — especially Protestant fundamentalism. ${ }^{316}$

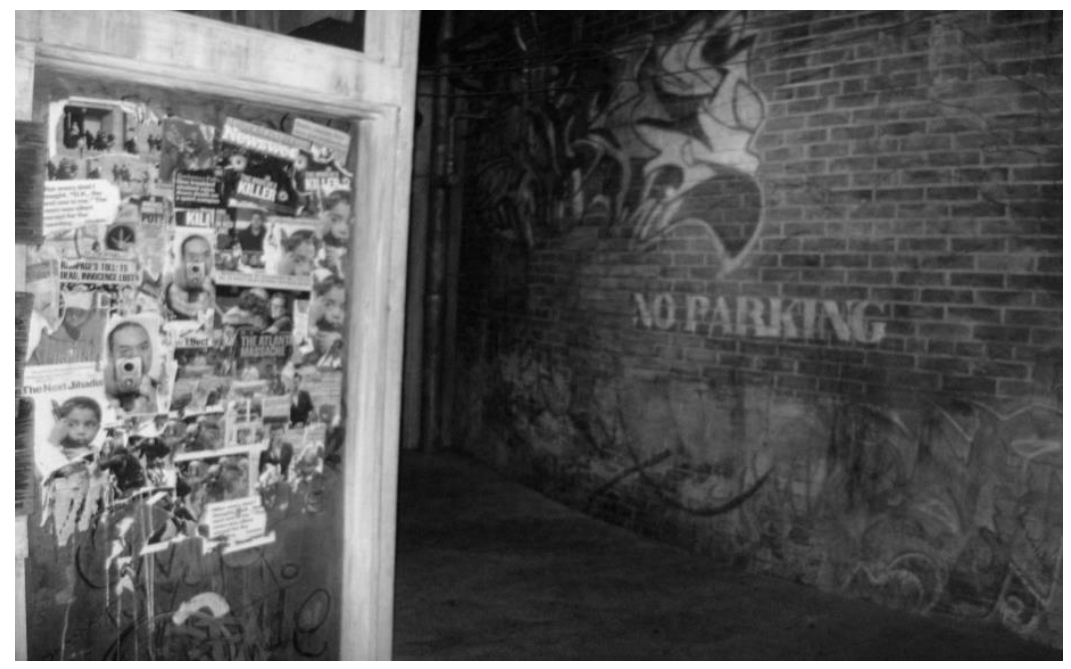

Photo 3. Pictured here is Graffiti Alley, the walkway into Culture in Crisis. Photo: S. Watkins

The CM provides the purpose for this exhibit: "Graffiti Alley - The hopelessness and lack of meaning in life, as expressed within this alley, represent what happens when the Bible (our only absolute authority) is taken out of a culture, as has happened in onceChristian nations." 317 This approach taps into fear of what the world is becoming. Yet, it

\footnotetext{
${ }^{315}$ I deal with the selective use of imagery in Chapter V. This will be addressed as a form of screening information.

${ }^{316}$ For this tendency in Protestant fundamentalisms, especially of the premillennialist variety, see: George M. Marsden, Fundamentalism and American Culture, $2^{\text {nd }}$ ed. (Oxford: Oxford University Press, 2006), 38 and Martin E. Marty and R. Scott Appleby, The Glory and the Power: The Fundamentalist Challenge to the Modern World (Boston: Beacon Press, 1992), 49. For this tendency in a broader scope of world fundamentalisms, see: "Wrestling with the World: Fundamentalist Movements as Emergent Systems," in Gabriel A. Almond, R. Scott Appleby, and Emmanual Sivan, Strong Religion: The Rise of Fundamentalisms around the World (Chicago: The University of Chicago Press, 2003), 145-90.

${ }^{317}$ Journey Through the Creation Museum, 34.
} 
is a highly selective use of imagery. ${ }^{318}$ Spray painted in red, white, and blue is the phrase, "Modern World Abandons the Bible.” This phrase appears under a placard which says: "Scripture Abandoned in the Culture Leads to ... Relative Morality, Hopelessness and Meaninglessness." ${ }^{319}$ A subtle, yet effective, indexing takes place at this point. The last scene before entering Graffiti Alley is that of the Scopes courtroom. This pejorative scene is a powerful bridge into chaos as it stands as a solid defeat for creationists. But it is also presented as the latest attack on the Bible as the legal precedents through secondary education have been to prohibit the teaching of creationism - in any form - in the science curriculum. $^{320}$

At this point, the visitor has been walked through the glorious revelation of the ancient prophets, the ongoing history of the battles between the forces of evil and the word of God (Biblical Authority). Then a nostalgic presentation of Luther, holding firm to the principle of sola scriptura, inspires the visitor to be aligned with the Protestant cause of defending the Bible from corruption. The current attack is evolution as seen in the last historical stop — the Scopes exhibit. What follows the latest evolutionary attack is utter moral chaos. This connection is made explicit in the next room.

${ }^{318}$ Graffiti Alley and the following room, Culture in Crisis, select the most pejorative elements from modernity as the inevitable direction of society when the Bible is pushed to the margins of public policy. Modernity is presented by fundamentalists as the big "enemy." Modernity is inextricably tied to three aspects of the world that fundamentalists reject: science, biblical and historical criticism, and secular democracies. See Marsden, Fundamentalism and American Culture (199-228), for a thorough discussion of these three aspects of modernity. As will be discussed in Chapter V, a vast amount of beneficial aspects of modernity appear nowhere - i.e. research hospitals, longer life-spans, nutrition, health care, declining crime rates, etc.

319 The quotes are transcribed from a photo taken of the wall and placard located in the Graffiti Alley exhibit of the Creation Museum (December 2, 2013).

${ }^{320}$ For documentation of this legal trend, see Edward J. Larson, Summer of the Gods: The Scopes Trial and America's Continuing Debate Over Science and Religion (Cambridge, MA: Harvard University Press, 1997) and Glenn Branch, "Understanding Creationism after Kitzmiller," BioScience 57 (March 2007): 278-84. 
Culture in Crisis (CIC) is the larger exhibit that follows the short walk through Graffiti Alley. CIC is not well illuminated either, but it is not quite as dark as the Alley. The CM explains the purpose of CIC:

Culture in Crisis Room - This room shows where the problem in the culture began. A church whose leadership has accepted contemporary ideas about millions of years and evolution is featured. The pastor is preaching that Christians can reinterpret Genesis to fit with man's ideas about the age of the earth. The adults are listening, but the teenage children are not. They see the hypocrisy of such a position that undermines biblical authority. This attack on biblical authority is represented by the wrecking ball smashing into the foundation of the church. ${ }^{321}$

Repeated again is the central issue of authority. The reason American culture is in a state of crisis is because it lacks an ultimate moral authority. This room may be the best example of the fundamentalist position against the modern world. It finally accuses Christianity itself as the culprit for the current crisis. The quote above refers to the scene of a church being knocked down by a wrecking ball labeled "Millions of Years." In one of the church's broken windows a video screen shows a contemporary church service in which the preacher gives an interpretation of the Bible informed by scientific understanding. However, such a sermon is offered as the single most important reason why, the culture is in such a crisis. In other words, liberal and progressive interpretations of the Bible are said to be the reason why younger Christians do not accept the absolute authority of the Bible. ${ }^{322}$

Across from the scene of the church are windows into the homes of the same young people presented in the video attending the church service. One video shows a girl talking on the phone about getting an abortion. Another scene shows a boy looking at pornography on a computer as another uses drugs. The causes of corruption are directly

${ }^{321}$ Journey Through the Creation Museum, 35.

${ }^{322}$ In the concluding chapter of this dissertation I will discuss this assertion. 
tied to non-literal or liberal interpretive views of the Bible. ${ }^{323}$ As the CM describes the scene, "When Christians and Christian families no longer promote the absolute authority of God's Word, they reap the consequences in the next generation." ${ }^{\text {,24 }}$ The answer to the cause for corruption is said to be the rejection of the Bible as the ultimate authority. However, what is really meant is that someone must interpret the Bible exactly as the CM does - in a selectively literal and young-earth fashion. ${ }^{325}$ But the second aspect of this chapter's title - the solution to corruption is presented in the exhibits that follow CIC.

Before I discuss the next set of exhibits, I need to summarize the idea of coherence as it has developed in the unfolding narrative so far. As Fairclough describes, "Coherence requires two important connections: "(i) between the sequential parts of a text; and (ii) between (parts of) a text and 'the world. ${ }^{, 326}$ First, the sequential parts of the biblical text cohere as they provide an explanatory grid to fit any period in human history-especially since history is seen as the unfolding of a dualistic struggle between the truth of God and the corruptions of humanity. At the same time, coherence also derives from what is asserted as the only indubitably certain epistemological approachi.e. the Bible as the lens through which everything is properly interpreted. The narrative set forth provides the following pattern. Any time the Bible is questioned, it is an obvious attack on the authority of God's revelation which is parallel to the first attack by the serpent, Eve, and Adam. These attacks - in the form of questions, doubts, criticism, or

${ }^{323}$ The CM does not present the numerous views on evolution that are accepted by many evangelical Christians. See Geral Rau, Mapping the Origins Debate: Six Models of the Beginning of Everything (Downers Grove, IL: IVP Academic, 2012).

324 Journey Through the Creation Museum, 35.

${ }^{325}$ One glaring contradiction here are the examples of equally conservative and authoritative approaches to the Bible (fundamentalist and evangelical) in which non-young earth and pro-evolutionary views are taken. For example, consider the Discovery Institute's "Intelligent Design" movement (http://www.discovery.org/) or Hugh Ross's "Reasons to Believe" organization (http://www.reasons.org/).

${ }^{326}$ Fairclough, Language and Power, 65. 
denials - are always placed on the dualistic side of evil. Consequently, the faithful and true believers always oppose the attack by seeking to restore the authority of the Bible to its proper and preeminent place. ${ }^{327}$

Ham's ability to connect the sequences of texts as an overarching metanarrative is fascinating. For example, he almost never mentions Genesis 2 as that creation account differs in several important ways from Genesis 1. Rather, he uses Genesis 1 and 3 as grounding texts for both an ex nihilo creation event and as the ultimate explanation for the cause of evil in the fall of Eve and Adam. He then indexes the epic event of the fall in Eden with the need for the doctrine of inerrancy. ${ }^{328}$ This connection creates a sense of severity because it places the CM's notion of inerrancy on the same footing as the human fall into sin. The connection is made through the use of doubt or questioning as the root evil. After all, it was the serpent who inserted doubt as it posed the question to Eve, "Did God say, 'You shall not eat from any tree in the garden?',"329 Any doubt or question one may have concerning the literal truth of what is stated in Genesis is aligned with the great sin of Eve, which brought down humanity and ushered in the world of pain and suffering. Coherence also results from Ham's supplying "missing links" to fill in the constructed narrative. In describing how sequential parts of texts contribute to coherence, Fairclough writes: "Implicit assumptions chain together successive parts of texts by

\footnotetext{
${ }^{327}$ In the concluding chapter, I will elaborate on the difficulty this poses in a secular democratic form of government, such as the United States.

${ }^{328}$ The following quotations from Ham's book document the narrative that also emerges in the imagery of the exhibits: "The first attack was on the Word of God. Satan's [notice here Ham's substitution of Satan for the serpent] method was to cause Eve and Adam to doubt the Word of God, so that doubt would lead to unbelief" (24) ... The acceptance of the literal events in Genesis is foundational to the question of biblical inerrancy. If the conferences on inerrancy were to settle that issue first, the rest of the problems they have would disappear very quickly" (183). Ham, The Lie. It is also important to note that the doctrine of inerrancy is relatively recent in Protestant history. See Marsden, Fundamentalism and American Culture (4 ff.), Kathleen C. Boone, The Bible Tells Them So, (23-37), and Karen Armstrong, The Battle for God, (170 ff.).

${ }^{329}$ Genesis 3:1 (New Revised Standard Version).
} 
supplying 'missing links' between explicit propositions, which the reader/hearer either supplies automatically, or works out through a process of inferencing. ${ }^{, 330}$ As noted above, one example of this occurs through his linking the serpent with Satan. Ham takes one verse, 2 Corinthians 11:3, and uses it to subtly present Satan as the serpent and thus, links the ancient text with a first-century epistle.

In 2 Corinthians 11:3, Paul has a warning for us: "But I fear, lest somehow, as the serpent deceived Eve by his craftiness, so your minds may be corrupted from the simplicity that is in Christ." Let me paraphrase this for you. Paul is warning us that Satan is going to use the same attack against us (and on our children, grandchildren, friends, family, and others) as he did against Eve to get us to a position of not believing the things of God. ${ }^{331}$

Notice the conflation of the serpent and Satan by Ham. Even 1 Corinthians does not make this connection. Rather, Ham uses the phrase italicized above- "Let me paraphrase this for you"- to create a sequential link missing from the biblical texts. This "paraphrase" is really an interpretive sleight-of-hand wherein Ham joins disparate texts to form a single thread. The only texts I am aware of that link the terms serpent and Satan are from the book of Revelation. ${ }^{332}$

Although it is never explicitly stated, one gets the idea that any true problem throughout history is a matter of not believing the Bible in the inerrant sense espoused by the CM. The solution to any problem is always said to be a matter of increased faith in the Bible. The narration through the Biblical Authority room is divided by episodes of trouble. For example, idol worship in ancient Israel, the corruption of world religions, historical criticism of biblical history, and the Enlightenment push toward secular society

${ }^{330}$ Fairclough, Language and Power, 67.

${ }^{331}$ Ham, The Lie, 23 [emphasis mine].

${ }^{332}$ Revelation 12:9 states: "The great dragon was thrown down, that ancient serpent, who is called the Devil and Satan, the deceiver of the whole world - he was thrown down to the earth, and his angels were thrown down with him" (New Revised Standard Version). Similarly, Revelation 20:2 states: "He seized the dragon, that ancient serpent, who is the Devil and Satan, and bound him for a thousand years" (New Revised Standard Version). 
are all presented as times when the Bible was questioned, doubted, or rejected outright. This dualistic division of good times (when people believe the Bible) and evil times (when the Bible is questioned or rejected) forms the structure necessary for the sequencing of texts in a way that provides coherence.

The visitor has been primed to see human struggle as always some manifestation of unbelief in the Bible. Therefore, when the visitor enters Graffiti Alley and Culture in Crisis, the expectation has already been planted that the Bible is once again under attack. ${ }^{333}$ This is made explicit through the use of phrases in graffiti and in printed placards. The message is reinforced as one walks through the ruin of a ghetto and into scenes of a culture in actual crisis_-"Modern world abandons the Bible" and "Scripture Abandoned in the Culture Leads to ... Relative Morality, Hopelessness and Meaninglessness. ${ }^{334}$ The phrases selected match the overall message that the world is getting much worse. Problems such as drug abuse, pornography, and abortion are vitriolic signs that evil is at work for conservative Christians. Moreover, the "history lesson" in the Biblical Authority room has primed a particular God/self/world schema to readily identify evil as a natural result of the Bible being doubted, criticized, or rejected as inerrant.

Fairclough describes how coherence develops with the term "gap-filling." 335 That is, filling in the causal connections for why the world works as it does. This happens unconsciously as well as consciously. Gap-filling, as Fairclough uses the term, refers to an operational inferencing that happens in all sorts of different interactions with texts and

\footnotetext{
333 "Christianity is Under Massive Attack" is the title to Chapter One in Ham's book, The Lie, 27.

${ }^{334}$ The quotes are transcribed from a photo taken of the wall and placard located in the Graffiti Alley exhibit of the Creation Museum (December 2, 2013).

${ }^{335}$ Fairclough, Language and Power, 67.
} 
words. For the God/self/world schema described in this chapter, assumptions about the world are a key to understanding why things are the way they are. In the case of Culture in Crisis, one gap is filled by the cross section of a church being destroyed by a wrecking ball labeled, "Millions of Years" (Photo 4, below). The visitor has already been filling-inthe-gaps to understand the basic logic of the museum. When trouble occurs, it is tied to an attack on the Bible. The scenes of crisis (drugs, pornography, abortion, etc.) are all connected to the image of the church. The church is also part of the crisis as the preacher is portrayed as taking a liberal or mainstream view of science. The attack featured in the modern world is the theory of evolution—indexed by the wrecking ball. Modern problems are all connected with a larger lack of credibility in the Bible. The attack on the Bible in this era is evolution.

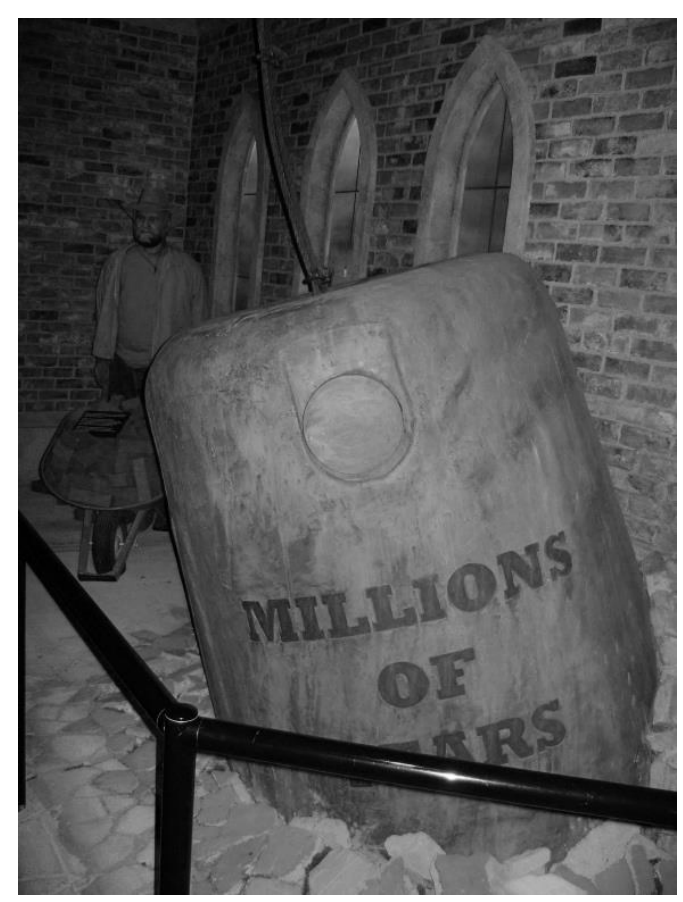

Photo 4. The church is being destroyed by a wrecking ball labeled "Millions of Years." Photo: S. Watkins 
Symbolically, the church is being destroyed, but at the same time the destruction of the church is the cause of the other crises in the surrounding culture. Coherence is formed through the linking all of the problems of humanity to a centralized source- the lack of biblical literalism as practiced at the $\mathrm{CM} \cdot{ }^{336}$ The images and sprinkling of Bible verses all work together to form an actual text. The visitor is walking through history as represented as an example of what happens when the Bible is rejected. The actual selections of Bible quotations have not been abundant so far. But they do increase as the visitor proceeds through the Seven C's - the organizational structure of Bible from Genesis 1-11.

The second of Fairclough's categories for coherence- - "between (parts of) a text and "the world"'-is relatively easy to identify. In fact, the overall narrative discussed thus far has consisted of matching biblical texts to explain why the world is as it is. The dualist world has been divided into competing forces. The forces of good are those presented as fighting for the proper place of the Bible as the ultimate moral authority. The forces of evil always seek to subvert the Bible through the many attacks leveled throughout history. Any manifestation of corruption has something to do with the sinful realm. For example, the Scopes Trial exhibit marks the latest of these attacks as biblical literalists were humiliated by scientific testimony that put to shame the ill-equipped creationists. The CM matches any opposition to the young-earth position as an example of the dualist world's ongoing battle between the forces of good and evil. ${ }^{337}$

\footnotetext{
${ }^{336}$ It is quite interesting to note that all of the problems presented in the Culture in Crisis room are distinctly modern problems. However, there are still many more serious problems that have always been with human society — such as rape, murder, genocide, slavery, and racism — during times of extreme biblical literalism. I would point out that many atrocities have occurred because of extreme biblical literalism.

${ }^{337}$ References to the words attack, war, and battle appear frequently in texts based on the CM message and in the placards, display boards, audio, and video screens.
} 
A similar type of inferencing and gap-filling is present with the text/world side of coherence. Fairclough notes: "We can also apply the distinction between inferencing and automatic gap-filling to the text/world aspect of coherence: texts can be 'fitted' to worlds either automatically, or through inferential work. ${ }^{, 338}$ When this observation is coupled with the fact that a certain God/self/world schema already expects a struggle between good and evil, then the only job left is to selectively match up all the evidence that fits a particular interpretation of the Bible. ${ }^{339}$ In Fairclough's words, "what's already 'in' the interpreter - that is, the common-sense assumptions and expectations of the interpreter," are a set of conservative God/self/world expectations looking to identify the causes of corruption in a world that seems morally out-of-control.

Ham and the planners at the $\mathrm{CM}$ also form coherence by presenting evolution as an evil attack on ethics and morality. Either the Bible is perfect and absolute source of all morality, or there are no absolutes and humanity is left in a morass of relativity. Since evolution is said to be atheistic, such a view of the world explains the loss of moral absolutes. ${ }^{340}$ The leaders and planners at the $\mathrm{CM}$ whom I interviewed also took a negative view of the world.

One of my questions asked if they thought the world was getting better or worse. All of my informants stated that it was getting worse, especially the United States. This important "members' resource" helps to show why the modern world is represented as an

${ }^{338}$ Fairclough, Language and Power, 67.

${ }^{339}$ While I discussed "members' resources" in Chapter II, here I would note how Fairclough summarizes coherence: "The sense or coherence of a whole text is generated in a sort of chemical reaction which you get when you put together what's in the text and what's already 'in' the interpreter - that is, the common-sense assumptions and expectations of the interpreter, parts of what I have called 'members' resources' (MR)," Ibid., 65.

${ }^{340}$ Evolution is not religious or non-religious. It is simply a methodology that limits itself to naturalistic explanations. As mentioned previously, the CM limits exposure to the many Christian positions that are accepting of evolution. 
inner-city ghetto and a morally collapsing church. Selective biblical texts are then pulled and foregrounded (on placards, through audio/video, and other media) to match the world-in-crisis picture of reality.

The four exhibits discussed in this section show how an explanatory framework for interpreting history is set forth. Biblical Authority is given as the most important premise. ${ }^{341}$ The remainder of the $\mathrm{CM}$ is a retelling of how to properly interpret the first eleven chapters of Genesis. Convincing people of the correctness of this interpretation is the solution to corruption in the modern world — a point I will take up below. Evil is explained up to this point as any doubting or questioning of the revelation of Godparticularly the Bible. The Culture in Crisis exhibit prepares the visitor to want the answers to the "right interpretation of the Bible" so that society can be reclaimed for God.

For most visitors, the frame of a museum is likely a more unconscious form of authority. Museums are the places of cultural authority, but on my numerous trips to the Smithsonian museums, I can't ever remember thinking consciously that "I am now walking into a place of authority." Most publicly funded museums are mediating voices between the academy and the lay public. For visitors at the CM, a revisionist narrative is provided in which world history is retold. This "true history" stands in opposition to the "lies" promoted at secular museums of natural history and anthropology. But like most all museums - secular ones included - the scripts at the CM are divided between the experts of the CM staff and the lay visitor. When the lay visitor brings the internal resources of a God/self/world schema of fundamentalism, the CM narrative becomes extremely persuasive. of the Bible.

${ }^{341}$ By "biblical authority" the CM means a narrow, fundamentalist understanding of the inerrancy 


\section{$\underline{\text { Frames and Scripts }}$}

\section{A Lecture}

Georgia Purdom is the one of the most credentialed scientists on the CM staff. ${ }^{342}$ She regularly gives lectures on subjects pertaining to the biological sciences and Christian apologetics. I attended and recorded her lecture titled, "The Wonder of the Cell," on June 11, 2013. The one hour lecture was held in a large auditorium called Legacy Hall. Some lectures are also given in the Morris and Whitcomb lecture rooms. Larger audiences of between fifty and three-hundred people are situated in the Legacy Hall. This auditorium contains a large main seating area which is approximately the size of a basketball court. It contains a stage with professional lighting and a podium centered on the stage. Behind the podium is a large screen which displays images from a digital projector.

Purdom began the lecture promptly at the advertised time of 12:00 PM. She stated up front that she hoped the effect of her lecture on her audience was to make us say, "Wow!" It was her hope that such fervor would come from an increased understanding of how complicated and wonderful the cells in our bodies are. ${ }^{343}$ She also mentioned that this complexity is an obvious feature of God's design and intelligence. Further, the greater an appreciation one has for the complexity of the human body-as exemplified in the complicated interactions of a cell — the greater an appreciation one would gain for the one who designed these complexities.

Before speaking about the cell, Purdom begins by reading a passage from the New Testament letter of Romans: "For since the creation of the world His invisible

\footnotetext{
${ }^{342}$ Georgia Purdom holds a Ph.D. in molecular genetics from Ohio State University.

${ }^{343}$ The subject of the lecture is a human cell in the process of neutrophil extravasation (NE). NE is the process in which white blood cells travel to the site of an injury or infection in the body.
} 
attributes are clearly seen, being understood by the things that are made, even His eternal power and Godhead, so that they are without excuse." ${ }^{344}$ She then follows by interpreting the verse to mean that every physical attribute, from the cellular level to the vast cosmos, is evidence for the existence of a creator God. She asserts that people are without excuse for denying the existence of God because every physical feature of the universe is evidence for a creator. She adds to this description that the problem with physical evidence is that humanity is corrupted, due to the curse. This aspect of the God/self/world schema is crucial for the operational logic to work. For instance, if the physical world is such strong and irrefutable evidence for God, then why do many people, including scientists, choose to deny a divine deity? So there must be something else that accounts for the reason people turn to atheism. The curse of original sin is used as a theological explanation for why such evidence is suppressed or rejected. Additionally, the curse also helps to explain why so many scientists draw the conclusion that people evolved. Only a sinful mind could come up with such an explanation.

Purdom elaborates on the problem of corruption because of the fall as it has been presented at other points at the CM. As mentioned in Chapter III, sin has caused unregenerate people to misinterpret God's revelation. Offering an anecdote from graduate school, Purdom recalls being amazed at the complexities of genetics. Further, she told how she could not understand how her other, presumably non-religious, classmates could accept an explanation for such complexity without invoking a creative being. ${ }^{345}$ This

${ }^{344}$ Romans 1:20 (New King James Version).

${ }^{345}$ This strategy of using real life experiences to bolster the YEC position is common in many areas of the CM. Here, Purdom inserts the anecdote as an example that equally smart scientists (she and her classmates) fail to arrive at the same conclusions over the material evidence because of different presuppositions. This anecdote reinforces the argument of the Starting Points room. 
explanation serves to disarm the evolutionary position with the simple argument that scientists reach different interpretations because of different starting assumptions.

She then explains the basic premise established in the Starting Points exhibit. Her central premise is that because no person was present to witness what happened in the beginning of the creation, scientists cannot be certain — and thus fully truthful—as to what actually happened. Everyone must use assumptions when looking at the past because there are no first-person witnesses. Thus, everyone is in need of an absolutely certain account of the origins of the universe or else they are limited to hopeless speculation.

The strategy of locating earth history in the unverifiable past has been a successful component of the CM's argument. ${ }^{346}$ In other words, their idea of the unverifiable past means a lack of any written account or first-person witness to actual events. In the case of evolutionary history, there are vast ages that obviously fall outside any written historical account. Because there is no way to go back and retrieve a firstperson account, evolutionary history is presented as one big speculative guess. On the other hand, the YEC God/self/world schema understands God as a transcendent and omniscient being who always existed. As the Creator, this God has given the definitive history of how things really came to be as recorded in Genesis. Any competing scientific ideas are placed into the realm of highly questionable on the basis that scientists were not there in the beginning and that they are fallible and sinful, a condition which causes natural observations to be misinterpreted. Thus, any account that departs from that of the CM is equated with doubting God.

\footnotetext{
${ }^{346}$ Beginning on page 202 and explained in more detail in Chapter V, "Science Redefined," the CM makes a distinction between what they call "operation science" versus "origin science."
} 
Purdom's introductory remarks intend to pit evolutionary science on the side of man's reason (devoid of God) and the YEC interpretation (based on the proper interpretations of Genesis 1). Purdom never mentions the numerous other positions that Christians have taken on evolution nor does she mention other interpretations of Genesis 1. She does however, cast doubt on the scientific consensus of evolution by labeling scientists as subjective and fallible humans who are, if non-Christian, affected by the fall and are subject to draw wrong conclusions. This demonstrates the importance of the God/self/world schema as I have described above. ${ }^{347}$

After Purdom verbally establishes the logic of the Starting Points exhibit, she then moves into an exploration of the many fascinating aspects of the human cell. She begins with a reference to Robert Hooke (1635-1703), the father of microscopy, and a brief history of the developing scientific knowledge of the cell. ${ }^{348}$ The central portion of the lecture explained the process of neutrophil extravasation (NE). She accomplished this rather technical feat by first showing a Youtube clip of a video animation produced by Harvard University. The video shows the chemical processes that unfold inside a human cell during NE. ${ }^{349}$ The video is fascinating as it demonstrates a small universe of chemical processes inside both the human blood stream and inside a single white blood cell. In introducing the short, three-minute and thirteen-second, video Purdom explained

\footnotetext{
${ }^{347}$ A vast array of issues — philosophical, theological, and scientific — are dependent upon a God/self/world schema that is dualistic and that holds to total depravity. Total depravity is a distinctive aspect of Protestant theology that emerged from Calvinistic theologians who tied the condition to the original sin of Adam. There are, however, many nuanced aspects of this position and an entirely different side of Protestantism - the Arminian branches - that do not accept total depravity as it is presented at the CM.

${ }^{348}$ At this point in Purdom's lecture, the use of technical terms becomes frequent. I note the use of scientific jargon here because, throughout the course of the lecture, I was totally dependent upon Purdom to explain to me the meaning and context of these terms. I was in the script of student, dependent upon the lecturer for reliable information.

349 "The Inner Life of the Cell," Harvard University and XVIVO Animation, http://www.youtube.com/watch?v=wJyUtbn0O5Y (accessed January 1, 2014).
} 
how exceptionally complex the process was. She mentioned that she held a Ph.D. and had studied these processes for years. Moreover, she expected that the audience would not even begin to be able to describe such a complex process as NE even after hearing her lecture because it was extremely complicated. In my case, she was exactly correct. Rather, she said that her goal was that the audience, would say "Wow" at how complex the process was.

After playing the video, Purdom said that when she saw how amazing this process was she couldn't help but think of Psalm 139. She then read a portion of that Psalm: "For You formed my inward parts; You covered me in my mother's womb. I will praise you, for I am fearfully and wonderfully made; Marvelous are Your works, And that my soul knows very well." 350 She then began a detailed explanation of the process of NE as depicted in the video. As a non-scientist, it was not easy to follow her explanation as she employed technical terms and spoke at a fairly rapid rate. I did recall some terms from high school and college biology classes, such as endoplasmic reticulum, messenger RNA, ribosome, and plasma membrane. But I was only vaguely able to follow her larger explanation of $\mathrm{NE} .^{351}$

Purdom spoke for approximately thirty minutes as she explained NE. The last fifteen minutes of her lecture transitioned from explaining NE to an apologetic explanation of why Christians should begin all of their reasoning with the Bible. The CM's dichotomy of either creation or evolution was stated explicitly as she formed a

\footnotetext{
${ }^{350}$ Psalm 139:13-14 (New King James Version).

${ }^{351}$ In a chapter titled "Prepare to Believe: The Creation Museum," Sociologist Bernadette Barton made a similar observation after having listened to the same lecture by Purdom. She writes: "Her [Purdom's] lecture consisted of an extremely technical description of the elements of the cell in disciplinespecific language including, for example, explanations of "alleles" (a form of gene) and a "chromatid" (one-half of a replicated chromosome). I personally felt mentally taxed trying to follow the talk." Pray the Gay Away: The Extraordinary Lives of Bible Belt Gays (New York: New York University Press, 2012), 165.
} 
bridge between talking about the cell to moral and ethical issues. Before the shift to morality, she stated that the only choice was either evolution or creation, but that it could not be both. Purdom further ties this dichotomy to a statement made by Jesus in the gospel of Matthew: "He who is not with me is against me. He who does not gather with me scatters abroad. ${ }^{352}$ Forming such a dichotomy also works well for a dualistic religious schema. While Jesus was certainly not referring to evolution versus creation in the verse from Matthew's gospel, he was drawing a line of sorts between his followers and a large group of "others." Purdom aligns her YEC view with that of Jesus and places all evolutionists as those who oppose her-and by her implication, Jesus as well.

The final ten minutes of the lecture dealt with the issue of moral absolutes. Her assertion is fairly straight forward: Without an ultimate starting point (the Bible), there can be neither scientific nor moral certainties. She mentioned her disdain for talk shows in which people endlessly express their opinions. In reference to the debate over same sex marriage she made the rather bold claim that this was not an issue of public opinion but rather, of God's word. Purdom's voice became more high-pitched and agitated toward the end of the lecture. Her final appeal was that without the absolute truth of the Bible, people would be condemned by God. She quoted a few New Testament verses such as John 3:16. The last three minutes were spent talking about the books, DVDs, and other materials available for purchase in the CM bookstore. The lecture ended after Purdom mentioned the resources for sale at the CM. There was no time for follow-up questions.

Similar to the sermon which follows, the cause and solution for corruption were deeply embedded in her lecture. The reason that evolutionary scientists misinterpret physical evidence is due to the curse of original sin. As for social issues like same sex

\footnotetext{
${ }^{352}$ Matthew 12:30 (New King James Version)
} 
marriage, the answer is the same - that without a moral absolute (the Bible), society will wax more and more toward degeneracy. A literal reading of Genesis is the solution for proper science and proper ethics.

\section{A Sermon}

On November 24, 2002, Ken Ham delivered a sermon at the well-known Bellevue Baptist Church in Cordova, Tennessee. Bellevue is most famous as being one of the largest Southern Baptist congregations in the country. Further, Bellevue is the church that was previously pastored by Adrian Rogers (1931-2005), a staunch conservative and former president of the Southern Baptist Convention (SBC). Rogers has played a key role in the so-called "fundamentalist resurgence" of the SBC. ${ }^{353}$ The sermon that I will analyze was made into a DVD for sale at the CM. Titled, Genesis: The Key to Reclaiming the Culture, the sermon demonstrates the basic premises established at the CM. ${ }^{354}$ Essentially a summary of Ham's book, The Lie, this sermon asserts that a literal and historical belief in the truth of Genesis is the key to reclaim the culture in North America.

Ham takes the pulpit after a brief introduction by Adrian Rogers. The fortyminute sermon begins with the basic assertion that American culture is getting worse. First Ham asserts that the United States has been the greatest Christian nation in the world. He then poses the basis of his sermon:

But isn't it true that when you look at the structure in America, it's becoming less Christian every day? There is something really wrong with this culture. What has

\footnotetext{
${ }^{353}$ David Stricklin, A Genealogy of Dissent: Southern Baptist Protest in the Twentieth Century (Lexington, KY: The University Press of Kentucky, 1999), 124.

${ }^{354}$ Ken Ham, Genesis: The Key to Reclaiming the Culture, DVD (Florence, KY: Answers in Genesis, 2002).
} 
happened? I suggest to you that the church is no longer touching the culture like it used to because in many instances, the culture has infiltrated the church. ${ }^{355}$

Next, Ham reads a verse from John's gospel: "If I have told you earthly things, and ye believe not, how shall ye believe, if I tell you of heavenly things?" ${ }^{356}$ Ham then asks the question, "If we can't believe the history in the Bible. If we can't believe the earthly things, in the Word of God, how can you believe the heavenly things, the Christian morality, the message of salvation, that's based in that history?",357 As I have noted above, a central feature of Ham's hermeneutical strategy is to question New Testament passages juxtaposed with Genesis $1-11 .^{358}$

As Ham speaks, he periodically picks up a large, black and worn copy of the Bible when he references the Word of God. This visual gesture also suggests that the whole canonical Bible is one coherent document — rather than a widely diverse set of poems, genealogies, letters, prophecies, etc. He appeals immediately to the Christian Bible in its entirety as historically reliable. Casting doubt on the larger Christian categories of salvation, the historical Jesus, and resurrection, Ham creates coherence between the ancient primeval narratives of Genesis 1-11. This approach casts those who do not ascribe to the inerrancy of parts or all of the canonical Old and New Testaments as either inconsistent or outright unbelievers.

355 Ibid.

${ }^{356}$ John 3:12 (King James Version).

${ }^{357}$ Ham, Genesis (DVD).

${ }^{358}$ The CM position on inerrancy is one of the narrowest in Christianity. Part of their doctrine includes that, "The acceptance of the literal events in Genesis is foundational to the question of biblical inerrancy." Ham, The Lie, 183. This position has been called "verbal plenary inspiration" to include that all portions of the canonical, Protestant, Old and New Testaments are said to be inspired and without error of any kind. See R. Laird Harris, Inspiration and Canonicity of the Scriptures (Greenville, SC: A Press, 1996), $11 \mathrm{ff}$. 
Because the Bible is understood as containing no error whatsoever, Ham mentions

that if the Bible texts pertain to matters of geology, biology, astronomy, and physics,

among others, that the Bible must be correct. He states:

Let me ask you a question. The Bible, does it touch on geology, biology, anthropology, astronomy, physics, chemistry? Does the Bible touch on those things? You know I was at a university once and a man jumped up and he said, "But the Bible's not a science textbook." And I said, "You're right and I'm glad about that because science textbooks change every year." I'm glad the Bible's not a science textbook. But where the Bible touches on science, can we trust it? Absolutely, because if you can't trust those earthly things then how can you trust the heavenly things that are based in that history? ${ }^{359}$

Once more, the words of the New Testament, especially the gospel passages that include the words of Jesus, are placed under the same scrutiny as Genesis 1-11.

Ham relies heavily on the categories of doubt and subjectivity in framing his argument. Much of what he claims is certainly true. To begin with, humans are fallible and subject to mistakes. Second, science is always in the process of change. ${ }^{360}$ Third, Ham makes the following statement in his sermon:

What happened in the past to put people here? What happened in the past to cause death and suffering? You know the only way you'd know? If someone who was there in the past who saw everything happen who revealed to us what happened. So if you connect the past to the present. I've got news for you. I have a revelation [holding up the large Bible in his right hand] from one who has always been there, who said, 'Here's what happened in the past' [verbal "amens" and applause from the audience erupt after this statement]. ${ }^{361}$

Formally speaking, his assertion above is logically true. But of course the premises are subject to a wide range of different opinions. He further states that, "the Bible's history to

${ }^{359}$ Ham, Genesis (DVD). While Ham says that he does not believe that the Bible is a science textbook, the Bible is actually treated that way at the CM. My understanding of his reference here to "heavenly things," while not explicitly defined, means matters pertaining to salvation, resurrection, and the life of Jesus. "Earthly things," on the other hand, seems to include matters of physical, earth historyespecially the doctrine of creation ex nihilo.

${ }^{360}$ As I have noted above, scientific "change"-better described as "revision" and/or "refinement"- are among science's greatest strengths. But Ham understands any changing epistemological system as untrustworthy and subjective.

${ }^{361}$ Ham, Genesis (DVD). 
us should be a pair of glasses. When I put on my glasses [Ham puts on his glasses as he makes this statement] so that I can see the pages of the book. Really each one of us should be wearing biblical glasses twenty-four hours a day." ${ }^{\text {362 }}$ Although Ham denies that the Bible is a science textbook, the assertions he makes suggest that the Bible be used as a science textbook.

The remainder of the sermon turns toward cultural critique of Christianity in America. Similar to the message in the "Culture in Crisis" exhibit, Ham asserts that there are numerous problems in the churches across North America. While there is a general lack of specific examples of the problems, he asserts a statistic from the Barna research group: "Seventy percent of students from church homes, who go to public schools, after their senior year, walk away from the church. There is something dreadful happening in America. ${ }^{363}$ Declining church attendance is taken to be the most significant mark of America's moral decline.

The next phase of the sermon involves the dualistic schema of evil versus good. Ham asserts the same message as Purdom, "The Bible says that you are either for Christ or what? Against. You either walk in light or you walk in what? Darkness. ${ }^{״ 64} \mathrm{He}$ elaborates that the once Christian culture in America is being diminished because religion is being removed from public education. The issues of prayer in school, the Ten Commandments, teaching of creationism, and other religious matters are the result of a society that has not taken the Bible seriously. Anecdotes, such as a Boy Scout who became an atheist after learning evolution, are offered as examples of what happens when

${ }^{362}$ Ibid. As documented in Chapter II, Ham uses the metaphor of the Bible as a pair of glasses in his writing as well as his speaking engagements.

363 Ibid. of the Cell."

${ }^{364}$ This is the same reference to Matthew 12:30 that I cited from Purdom's lecture, "The Wonder 
Christianity is taken out of the schools. ${ }^{365}$ Ham is fervent to suggest that it is Christianity, rather than religion, that has been removed from public schools.

He returns to the subject of the Bible's authority to make his final appeal. Because science has given an account of the universe that differs from that found in the Bible, then either the whole Bible must be rejected or the Bible trumps every other form of truth. ${ }^{366}$ This dilemma, the dualists' division of good and evil, is once again set in terms of an either/or dichotomy. If Genesis cannot be trusted as historically reliable, then why should the Gospels be trusted as reliable? Ham states: "If the Bible doesn't have authority, why should the message of salvation be trusted?"367 Implicit in Ham's assertion is that the Bible must be understood at a literal, surface-level reading of the text. His suggestion is also that churches should teach "geology, biology, astronomy, anthropology, physics and chemistry in Sunday School, youth group, and Bible study.",368

Ham makes his final appeal by quoting a passage from Matthew's gospel in which Jesus referred to the Jewish custom of marriage by stating: "Have you not read, that he who created them from the beginning made them male and female? ${ }^{\prime 36} \mathrm{He}$ asserts that Jesus' understanding of Genesis is foundational to nearly all of his moral positions.

${ }^{365}$ Ham, Genesis (DVD). Ham makes this assertion but cites no sources concerning the Boy Scout.

366 "Truth," as used by Ham, is a complex epistemological category. In his understanding, as I have endeavored to conceptualize it, there can be no ultimate ontological reality unless the Bible is the supreme and perfect word of God. Additionally, this supreme category is immediately accessible and perspicuous to anyone who is able to read.

${ }^{367}$ Ham, Genesis, (DVD). Such an assertion is incredibly simplistic for one who has studied different theological systems - Catholic, Episcopal, Orthodox, and Protestant - and their approaches to soteriology. Ham's assertion only works for a God/self/world schema that is fundamentalist or extremely conservative evangelical. Further, the terms "Bible," "authority," and "trusted" all open up wide ranges of meaning. Two sources that have thoroughly explored these terms and the widely divergent meanings they might imply are: Brian Malley, How the Bible Works: An Anthropological Study of Evangelical Biblicism (Walnut Creek, CA: AltaMira Press, 2004); and James S. Bielo, Words Upon the Word: An Ethnography of Evangelical Group Bible Study (New York: New York University Press, 2009).

${ }^{368}$ Ham, Genesis (DVD).

${ }^{369}$ Matthew 19:4 (New American Standard Bible). 
In fact, Ham proposes that every major doctrine in theology is based on Genesis 1-11. Homosexuality, marriage, sin, death, seven-day week, man's dominion over the earth, Jesus' death on the cross, and why people wear clothes, are all said to based on the first eleven chapters of Genesis. "Genesis one-to-eleven is the foundation to the rest of the Bible. And the key to inerrancy in regard to the scripture is Genesis one-to-eleven." 370 The fact that the historical accuracy of Genesis was called into question led to the collapse of trust in the Bible as an authoritative source. Thus, when moral authority based on the Bible was gone, it was only a matter of time before the rest of society gave up on Christianity.

"You know what we see happening in America today? We see the collapse of Christian morality. Increase in secular humanism. You know why? Because there has been a change foundationally." ${ }^{371}$ Ham displays an image on a large screen that is adapted from a cartoon diagram in his book, The Lie (see Figure 6, below). ${ }^{372}$

${ }^{370}$ Ham, Genesis (DVD).

${ }^{371}$ Ibid.

${ }^{372}$ Figure 6 is the actual castle diagram printed in the first edition of Ham's book, The Lie (92). The image displayed in the sermon is almost identical, with two islands depicted as two competing "worldviews." However, in the color diagram in the sermon, the island labeled "evolution" also says "millions of years" and "man decides truth." The island labeled "creation" contains the words "thousands of years" and "God's word is truth." The only other differences are the labels for the balloons from the castle labeled "humanism." Instead of euthanasia, homosexuality, pornography, abortion, divorce, and racism, the balloons in the sermon are labeled homosexual behavior, family break-up, and euthanasia. Ham, Genesis (DVD). 


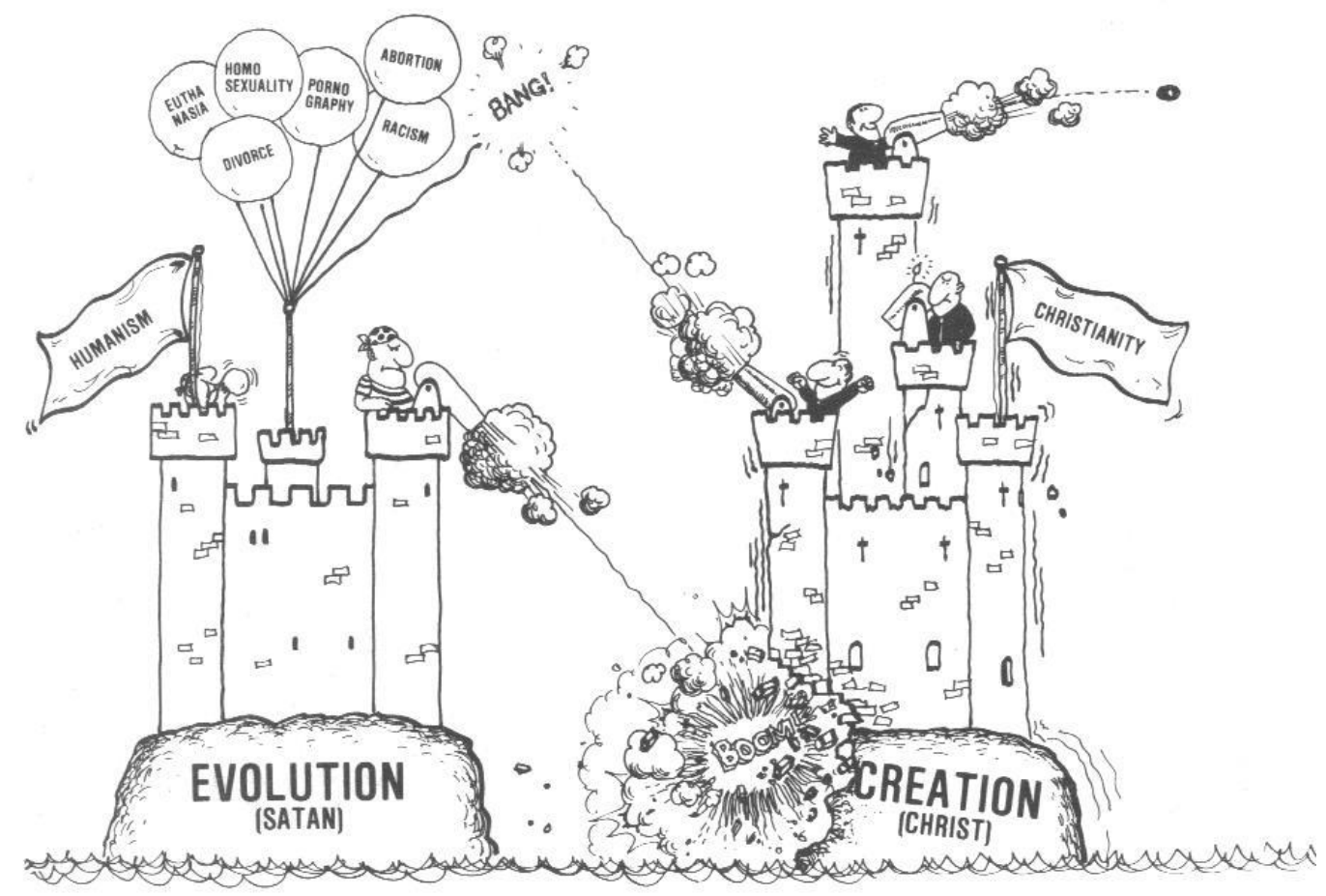

Figure 7. A cartoon representation of Ham's foundational logic. Ken Ham, The Lie (El Cajon, CA: Master Books, 1987), 92.

This image is especially telling because it shows the dualistic world divided neatly in two competing sides: evolution, Satan, and humanism versus creation, Christ, and Christianity. Christians are depicted as shooting cannon balls at social issues (divorce, abortion, homosexuality, etc.) that Ham claims are the symptoms of societal decay, rather than the root cause of the problem. Evolution is said to be the real problem. The island that humanism is built upon is labeled "evolution." As such, evolution is the foundational problem giving rise to all of the social and moral problems which are depicted as balloons. While showing the diagram on a large screen, Ham states:

We need to be attacking the wrong foundation of history that is so prevalent in our culture, so that we can rebuild that structure. You can't change a country, a culture from the top down when it's changed from the foundation up. You can't impose Christian morality on a culture that no longer has the foundation for it. 
We've got to deal with those foundational issues. And that's really what the ministry of Answers in Genesis is all about. ${ }^{373}$

Ham makes a few minutes of concluding comments by referencing the materials

for sale after the sermon. Like the ending of Purdom's lecture, he mentions the books, DVDs, magazines, and other published literature from Answers in Genesis. His final appeal is to visit the Answers in Genesis website and to subscribe to the Answers in Genesis magazine titled Creation Ex Nihilo. ${ }^{374}$ Ham closes with the words, "I pray tonight that you realize we need to take a stand on the authority of the word of God [raising the Bible with his right hand]., 375

This sermon is the most succinct, yet comprehensive presentation of the operational logic of the CM. The answer to the videos subtitle- "The Key to Reclaiming the Culture"- is the establishment of reading the Bible literally and making the Bible the sole authority over any area of study that it specifically addresses. The sermon casts the world into a dualistic split between those on God's side who take a YEC view of Genesis and the evil others who are lumped together as anyone who believes in evolution, humanism, and the elevation of human reason.

\section{Conclusion}

The CM effort to explain the causes of and solution for evil is a way of forming coherence for those who are willing to surrender their reason to the authoritative voices of the museum. As I have documented, the scripts of authority vary-museum placards

\footnotetext{
373 Ibid.

${ }^{374}$ After a prolonged legal dispute with the Australian organization Creation Ministries
} International (CMI), which also shared ownership of Creation Ex Nihilo with Answers in Genesis, relations with CMI were severed and a renamed version of the magazine became the sole publication of Answers in Genesis. The new magazine is simply titled Answers.

${ }^{375}$ Ham, Genesis (DVD). 
narrating history, a Ph.D. scientist giving a lecture, and a pulpit preacher-as do the frames for their delivery — a biblical history museum, a lectern in an auditorium, and a church pulpit. These forms of discourse work together as they imitate the form of the same institutions that have been established as authoritative sources of knowledge. Museums, lecture halls, and pulpits all serve as places where credentialed information is delivered. The CM effort to establish alternative sources of authority is somewhat analogous to legal proceedings. For example, often when an attorney wants to counter expert testimony that is damaging to her client, she hires a different, equally credentialed, expert who gives a contradictory interpretation to the first expert.

Further, I have used Fairclough's term schema to present an important set of religious assumptions, the God/self/world schema, that are necessary before the assertions at the CM makes sense or cohere. Conservative evangelical and fundamentalist thinking is largely dualist. A transcendent, all-powerful, and all-knowing God stands over every other source of knowledge. The world is corrupt because of original sin. Thus, all knowledge, except the perfect revelation of God, is subject to misinterpretation. The Bible, is understood to be a kind of decoding device. To use Ham's analogy, "the Bible's history to us should be a pair of glasses. ${ }^{, 376}$ The Bible is the lens that corrects the human sinful bent that is subject to misinterpret nearly everything.

Fairclough asserts that, "Schemata are a part of MR [members' resources] constituting interpretive procedures ... and frames and scripts are closely related notions." 377 Further, MR are said to be "what's already 'in' the interpreter - that is, the

\footnotetext{
${ }^{376}$ Ham, Genesis, (DVD).

${ }^{377}$ Fairclough, Language and Power, 131.
} 
common-sense assumptions and expectations of the interpreter." ${ }^{378}$ Because of the dualist's God/self/world schema, all sources of knowledge—scientific, theological, and philosophical — are subject to misinterpretation. The only authoritative source is God's revealed Bible. Coherence results when someone makes the most sense of the Bible, matching the Bible's texts with observations of the natural world.

Over all of the discourse stands the museum, an organizational frame for the whole CM campus. For true believers, it is a sort of ultimate museum because it presents the true, unadulterated words of God or, as Bodie Hodge responded, "this is unique in that it is a biblical authority museum." 379 Frames and scripts also work on a smaller scale within the museum. Georgia Purdom begins her lecture behind a lectern elevated above the crowd on a stage type of platform. She uses technology such as "The Inner Life of the Cell" to create awe on the part of a lay audience who are also assuming the script of "student." This video shows an extremely complicated — even mesmerizing—set of intercellular biochemical reactions. Purdom employs extremely technical scientific language such as neutrophil extravasation, endoplasmic reticulum, and nuclear pore complex as she interprets the video for her audience. This type of discourse establishes her expertise and appropriation of a wide range of scientific information that is unknown to non-specialists. She mentioned her Ph.D. in molecular genetics as well as her college teaching and research experience.

Similarly, a video shows a sermon delivered at an influential Baptist church. One of the leading conservative evangelicals, Adrian Rogers, introduces Ham and welcomes him to his pulpit. This gesture is an establishment of Ham's authority by Rogers. It is a

\footnotetext{
${ }^{378}$ Ibid., 65.

${ }^{379}$ The full interview quote is on page 151 of this chapter.
} 
sort of symbolic anointing ceremony. Ham further indexes authority with gestures that resonate in conservative Baptist churches. The most common is the raising of the Bible with his right hand while making an especially emotional appeal to the Bible's authority. He creates doubt by connecting the book of Genesis with the more important categories of Jesus and salvation. If someone cannot believe in one, then why should they believe in the other? Most lay people who I have dealt with, including six years of teaching religious studies, have no way to tackle such a question.

In every area of the $\mathrm{CM}$, the Bible is asserted as the interpretive lens that corrects the corruptions of unbiblical thinking. Ironically, a relatively sparse number of biblical passages are actually used at the museum. Most of the biblical references deal with the first eleven chapters of Genesis. But these verses are effective in explaining evil. The primeval tales of the fall in Eden, Cain slaying Abel, and Noah's flood all help to explain evil as what happens when people fail to believe in God's word. Evolution is actually equated with the Serpent's challenge to Eve. Evolution is the most recent in a long history of attacks on God's word, according to Ham.

So problems in the world, whether physical or moral, are tied to a lack of belief in the literal words of the Bible. As depicted in the cartoon (Figure 6), Christianity is under attack by the forces of evil-labeled "Humanism" and "Evolution." Ham's message is that if people will trust in the ultimate authority of the Bible, confidence in the Bible's credibility will succeed in erasing the dubious theory of evolution. Once evolution is gone, Ham suggests that evil will somehow be displaced. Society will no longer be duped by the lie of evolution and the Bible will gain its rightful place as the authority to replace 
all other authorities. Indeed, the "key to reclaiming the culture" is a selectively literal reading of Genesis. 


\section{CHAPTER V \\ SCIENCE REDEFINED: WHY A MUSEUM?}

The CM wants to establish epistemological certainty. This certainty could theoretically be applied to morals, ethics, politics and even the reclaiming of a culture said to be "in crisis." Described in Chapter III, the CM functions as a Complex Adaptive Network (CAN). As such, it cannot help but be influenced and shaped by secular culture in which it is immersed and is always interacting. Further, when analyzed as a CAN, it becomes a mirror image of the very thing that it seeks to oppose. For example, as it seeks to refute the academy as a whole, it appropriates several discursive structures of the academy it seeks to displace. The planetarium, the museum, and the lecture hall are some of the structures, or frames, used by the $\mathrm{CM}$ as discussed in the preceding chapter.

This chapter will analyze the CM as a CAN. As the chapter title suggests, the CM attempts to redefine science in several innovative ways. The first section explains the larger threat that science poses for a fundamentalist reading of ancient myth. Because knowledge is interconnected and co-evolving, the most obvious threat is any theoretical methodology that calls the myth into question. The second section documents how the CM tries to divide science into the realms of speculation and factual observation. The third section examines the various ways in which information is screened, as defined in Chapter II. Screening occurs on a variegated front. As an essential feature of discourse, screening occurs at every narrative structure of the CM. Section three analyzes screening 
as it occurs in the bookstore, museum exhibits, and in the CM's efforts to establish YEC peer-review.

\section{The Epistemological Threat of Science}

Proposing one definition for science is challenging. To establish the context involved in defining science in relation to the CM, it is first helpful to have a contrasting category with which to be compared. For this comparison, I will use the term “pseudoscience." 380 Sven Hansson immediately identifies creationism as an example of pseudoscience as opposed to evolutionary theory as an example of science. ${ }^{381}$ The points of demarcation between science and pseudoscience are established by Hansson in seven basic criteria. ${ }^{382}$ All seven criteria fit the version of pseudoscience offered at the CM. One important aspect of pseudoscience, as Hansson defines it, is that its "proponents try to create the impression that they are scientific (the criterion of scientific pretense)." ${ }^{383}$ What the CM is calling "science" is really a form of pseudoscience.

Viewed as a CAN, the CM's alleged history of the cosmos is constantly called into question by the scientific community-especially those fields that deal with evolutionary theory directly (biology, geology, and paleontology). One reason for such a high level of tension between the CM and science is that, to some degree, they are both

${ }^{380}$ Pseudoscience has become the adopted term used by scholars who study this phenomenon. See Massimo Pigliucci and Maarten Boudry, eds. Philosophy of Pseudoscience: Reconsidering the Demarcation Problem (Chicago: The University of Chicago Press, 2013); and Kendrick Frazier, ed. Science Under Siege: Defending Science, Exposing Pseudoscience (Amherst, N.Y.: Prometheus Books, 2009).

${ }^{381}$ Hansson, "Defining Pseudoscience and Science," in Pigliucci and Boudry, eds. Philosophy of Pseudoscience, 61. Hansson defines science as follows: "Science (in the broad sense) is the practice that provides us with the most reliable (i.e., epistemically most warranted) statements that can be made, at the time being, on subject matter covered by the community of knowledge disciplines (i.e., on nature, ourselves as human beings, our societies, our physical constructions, and our thought constructions)," 70 .

${ }^{382}$ Hansson, Philosophy of Pseudoscience, 72-3.

383 Ibid., 68. 
telling a story of history. ${ }^{384}$ I made the observation in a recent publication that: "Myth played a similar role for ancient people as scientific theory does for modern people."385 The common feature of myth and theory is that they are explanatory models that seek to interpret phenomena. Before critical scientific methodology, many people were left to explain the causes of natural forces as having divine causes.

The CM must constantly respond to the new insights of science that compete for public legitimacy. However, the general public are not predominantly scientific specialists - especially in the fields of evolutionary science. This fact provides the CM with the ability to cast doubt on the definition of science and to replace it with their own pseudoscientific substitute. One reason for this advantage is because both science and religion deal with the realm of things that cannot be seen. For example, black-holes and quarks are not able to be visibly verified, but this does not mean that they do not exist. In fact, a recent proposition is that science is counterintuitive and religion is naturally intuitive. $^{386}$

When one combines deeply held religious beliefs with common sense observations of phenomena that do not appear to be congruent with what scientists are saying, the CM position is easier to communicate and to maintain for lay audiences. Christians who are already committed to a position of biblical inerrancy are threatened by any evidence that suggests that the Bible was not accurate or scientifically correct. Thus,

384 Taylor, The Moment of Complexity, 211.

${ }^{385}$ Watkins, "Dragon Snakes," The $4^{\text {th }} R, 8$.

${ }^{386}$ Robert N. McCauley, Why Religion is Natural and Science is Not (Oxford: Oxford University Press, 2011). A perfect example of this may be seen in the Galileo affair. New technical, scientific data called into question the statements in the Bible that made it seem that the earth was central with the sun orbiting earth. After all, from a human, naked-eye point of view this seems obvious. The sun does indeed appear to rise and set. To say that we are spinning in relation to the sun is incredibly counter-intuitive. 
such a visitor already holds the expectation that the CM can provide an equally valid explanation of physical evidence that preserves one's religious commitments.

The CM's effort to answer science has an ironic result in that it has borrowed the vocabulary of the scientific academy, yet differs in the way it uses those terms. As discussed previously, the museum is a place where scientific language is translated and interpreted for the laity. It becomes a "space of translation" in which the terms can be assigned different meanings while still telling a story rich in the jargon and artifacts of the sciences.

Discoveries in the field of evolutionary science threaten the CM's existing paradigm. As we have seen thus far, two non-negotiable aspects of their theology is that evolution could not have happened and that the earth is roughly six-thousand years old. Any scientific evidence that challenges those presuppositions must be explained and interpreted in a way consistent with these two tenets. Thus, the museum becomes a structure for a mediating discourse that reshapes public perception of the challenges of science. The majority of exhibit space is devoted to answering the most popular challenges that science poses. Among these challenges are the nearly iconic images of dinosaurs, fossils, "ape-men," and the picture of the "march of human progress." ${ }^{, 387}$ At the same time, the CM seizes on these same iconic images to construct apologetic strategies.

${ }^{387}$ These iconic images take a variety of forms, from popular culture to public museums such as the National Museum of Natural History, The Field Museum, and the American Museum of Natural History-to name those which are among the most well-known. Stephen Jay Gould has written on the difficulty of dislodging iconic images that have become deeply rooted in the public psyche-and this is true for evolutionists and creationists alike. His major example is the famous, "march of human progress" - a widely familiar image that shows five earlier primates walking behind a more developed one, ending in modern homo sapiens. Gould explains that this is not a scientific idea as many earlier primates were close cousins, and not ancestors of modern humans, Stephen Jay Gould, Wonderful Life: The Burgess Shale and the Nature of History (New York: W. W. Norton \& Co., 1989), 29-36. 
The first example of such a response is the recently constructed Lucy exhibit, located in the Starting Points room. The world famous Lucy fossils (Australopithecus africanus - ST5) have been evaluated by professional paleoanthropologists to be the roughly two-and-a-half million year old early hominid bones. ${ }^{388}$ The scientific consensus is that Lucy was bipedal, meaning that she walked upright as well as on all four limbs. This set of bones has provided examples of early hominids that were ape-like, but also carried features more closely related to advanced primates. Lucy challenges the beliefs of YEC on two fronts - an age well in excess of six-thousand years and as an intermediary primate in human evolution. This is an example of how information from the scientific community challenges the interpretive schema of the CM. Lucy is so well known that the CM feels compelled to give an elaborate reinterpretation.

The result is an effort by the CM to present another, supposedly equally scientific, interpretation of the Lucy fossils. The Lucy exhibit consists of a state-of-the-art display cabinet with a life sized reproduction made to look like the CM's idea of what Lucy would have looked like. This is a revisionist presentation of the scientific consensus. First, they make the assertion that Lucy was a knuckle-walker. One publication makes the following comment: "A young-earth creationist has no problem depicting Lucy as some sort of ape. ${ }^{389}$ On the other hand, Doug Henderson accuses evolutionists as being influenced by their bias. “To ensure that Lucy's bones fit their bias, evolutionists give her long, humanlike legs and very humanlike feet."390

\footnotetext{
${ }^{388}$ It should be noted that two-and-a-half million years is an approximation of the current consensus which is listed as "between 2.8 and 2.3 Ma," Richard G. Klein, The Human Career: Human Biological and Cultural Origins, $3^{\text {rd }}$ ed. (Chicago: The University of Chicago Press, 2009), 730.

389 Doug Henderson, "Bringing Lucy to Life," Answers 8 (Jan.-Mar. 2013), 65. Henderson is an artist at the CM who worked on the Lucy project.

${ }^{390}$ Ibid.
} 
Another implicit tactic in the CM's Lucy display is the casting of doubt as to what she actually looked like. The scientific community is the first to admit that the best they can do are artistic renderings based on calculations from the fossils. Even the fossils are incomplete and they contain gaps of space in between some of the arm and leg bones. This is not disputed by either side. But the CM inserts doubt by claiming that because there are gaps in the bones, evolutionary scientists are making a big guess as to what Lucy looked like. They believe interpreting Lucy as an ape is just as plausible as seeing her as an early bipedal hominid. In my repeated visits to the Smithsonian's David H. Koch Hall of Human Origins, the exhibits on Lucy provided a vast amount of information on why Lucy is an early bipedal hominid. ${ }^{391}$ A visitor can compare footprints from the fossil layer consistent with Lucy to see how much more human than ape-like they are. A detailed multimedia exhibit shows how Lucy's spine and skull were connected. This is compared and contrasted with human and ape skeletons. The comparison is quite revealing, showing how Lucy was much more in-between older primates and/or modern apes.

Consistent with the logic in Starting Points, the CM continues to drive a wedge between interpretations of Lucy as either just another knuckle-walking ape or an example of an intermediary hominid consistent with evolution. Once again, doubt is the key ingredient in their argument. In the Lucy display case, the replica is standing on many photos of different artistic renderings of Lucy's facial features. A placard then asks visitors which photo of Lucy they choose, should they disagree with the display by CM artists. Without critical engagement, visitors feel like their choice is just as valid as any other. The idea put forth is that scientists are not any better at interpreting what Lucy

\footnotetext{
${ }^{391}$ This exhibit is located inside The National Museum of Natural History, Washington, DC.
} 
looked like than the CM. Further, because the earth is said to be six thousand years old, then obviously this was not a two-and-a-half million year old hominid fossil. A Starting Point of anything older than six-thousand years is said to directly and unequivocally contradict the Bible. The visitor is forced to decide between the always changing opinions of science or the certainty of the word of God.

I have noticed similarities of style between the CM's "scientific" exhibits and those at the Smithsonian's Human Origins exhibit. For example, in both museums the level of lighting was reduced and the use of backlighting and shadowing accentuated certain points of interest. The frequent use of guiding questions was a common feature on placards and video prompts. Touch screens with brief explanatory scripts invited visitors to investigate a question further — with the narrator supplying added evidence in answering the initial question. Cast fossil replicas and mock-up scenes with background landscapes were also similar. Both museums used cast metals to portray scenes that may be touched by children in order to engage the tactile and kinesthetic dimension of learning.

Another prevalent technique is the use of parallel objects for comparison. In the Koch Hall of Human Origins, a chimpanzee is pictured next to a human. Below each, a text explains the shared features of both primates as well as the divergent features that may be traced back to earlier primates such as Homo erectus and Australopithecus afarensis. Parallel comparison is a helpful way to compare and contrast similarities and differences while maintaining an overarching contextual subject-such as primates. The CM uses parallel comparisons even more frequently than in the Hall of Human Origins. 
But the CM uses the parallel comparisons as a way to drive a wedge between secular science and the YEC viewpoint - the main subject of the Starting Points exhibit.

In both the CM and the Hall of Human Origins, the visitor is placed in the role of an investigator. The guiding questions instill a sense of discovery. A subtle form of empowerment ensues as the investigator feels that she is active in the process of uncovering the truth. In the case of the $\mathrm{CM}$, this is even more important because the God/self/world schema of most visitors assumes that the corrupted world—of which evolutionary scientists play a central role-must be interpreted in a special way that utilizes the vision of God and the Spirit to give special insight. Human sin jades the average person from seeing things as they really are. Therefore, the Starting Points room explains that if one is to have any hope of knowing what really happened in the past, they must start with an infallible perfect record of the only witness to the actual events - God.

The CM is designed to appear like secular museums of natural history. Stephen Asma has highlighted the similarities between the CM, the Koch Hall of Human Origins, and the Field Museum. ${ }^{392}$ Two current terms employed by scholars of museum studies are "edutainment" and the "new museology." These terms refer to new design features in museums that engage visitors. Touch screens, the use of guiding questions, animatronics, metal cast replicas, and other hands-on features allow visitors to more actively engage with subject matter. There continues to be a vigorous debate about where the lines should be drawn between entertainment and education in museums. ${ }^{393}$ In any case, the CM is

\footnotetext{
392 Stephen T. Asma, "Risen Apes and Fallen Angels: The New Museology of Human Origins," Curator 54 (April 2011): 141-63.

${ }^{393}$ The debate is discussed in the following sources: Stephen T. Asma, Stuffed Animals and Pickled Heads: The Culture and Evolution of Natural History Museums (Oxford: Oxford University Press, 2001); Greg Dickinson, Carole Blair, and Brian L. Ott eds. Places of Public Memory: The Rhetoric of Museums and Memorials (Tuscaloosa, AL: The University of Alabama Press, 2010); Hilde S. Hein, The Museum in Transition: A Philosophical Perspective (Washington DC: Smithsonian Books, 2000); Ivan
} 
state of the art as far as employing the latest features of the new museology and edutainment to engage visitors. In this respect, the frame of a legitimate natural history museum is ubiquitous throughout the main exhibits. Even entering the foyer creates this impression as a large mastodon skeleton dominates the Main Hall.

The interactive nature of the CM also instills a sense of "ownership" of the information being processed. Asma astutely notes that:

Americans - even evangelical Americans - believe the power of "choice" is supreme, and so a growing number of Christians feel comfortable choosing a different origin story than the materialist scientific one. The Creation Museum emboldens them to do so because it invokes a naïve "show me" empiricism: "Hey, I don't see evolution happening.,"394

Given Asma's observation, I propose that the CM has a far easier job in conveying its message than do secular natural history museums. Evolutionary science-like numerous other scientific fields - is vastly complex and often counterintuitive. There is no easy and entertaining way to learn the procedure of radiometric dating or the mathematics required to measure astrophysical calculations of distant stars and galaxies. Rather, the CM appeals to non-specialists who already harbor deep religious convictions about origins. Many fundamentalists and evangelicals are already skeptical of higher education and the academy. ${ }^{395}$ When condescending and anti-theist quotes from prominent scientists-like Richard Dawkins and Daniel Dennett — are attached to the evolutionary message, it is far easier to convince Christians that evolution is just a bunch of far-fetched fancy talk by

Karp and Steven D. Lavine eds. Exhibiting Cultures: The Poetics and Politics of Museum Display (Washington DC: Smithsonian Books, 1991); and Stephen E. Weil, Making Museums Matter (Washington DC: Smithsonian Books, 2002).

${ }^{394}$ Asma, "Risen Apes and Fallen Angels," 146.

${ }^{395}$ Mark A. Noll, The Scandal of the Evangelical Mind (Grand Rapids, MI: Eerdmans, 1994); and Richard Hofstadter, Anti-Intellectualism in American Life (New York: Vintage, 1962). 
people who want to destroy their faith. ${ }^{396}$ For visitors who hold to the God/self/world schema described above, the CM becomes the most legitimate type of museum in existence. It is a place where Christians can get the real answers that are suppressed at secular natural history museums.

There is, however, a highly paradoxical aspect of CM efforts to respond to the secular academy. The accomplishments of science — especially applied technologies such as space craft, satellites, and nuclear radiation — are undeniable. YECs know that the scientific method is effective and prestigious. The technologies used at the CM are among the best available. Nearly every secular writer on the CM notes the level of technical sophistication present, from planetarium projectors to the special effects theater. A certain amount of scientific vocabulary, along with many of the technologies produced by science, is appropriated to enhance the pseudoscientific ideas promoted at the CM. ${ }^{397}$ One central paradox is that, in attempting to discredit the very thing it opposes (science), it ends up mimicking the same institution that it seeks to oppose.

This paradoxical dynamic is exactly what information theorists have proposed. Describing the dynamics of CANs, especially with respect to how symbolic networks interact, Taylor has written that "order and disorder are not opposite but are codependent in such a way that neither can be what it is apart from the other." ${ }^{, 398}$ Pursuing this irony a bit further, the CM is in a sort of symbiotic relationship with the scientists who present a competing narrative of earth history. David Aaron has picked up on this same phenomenon as he reflected on my explanation of the CM as a CAN. "The profound

\footnotetext{
${ }^{396}$ For example, consider how a religious person might be offended by the title of Richard Dawkins' The God Delusion.

${ }^{397}$ Sven Ove Hansson has emphasized a central characteristic, cited on page 189 (above) that he calls the "criterion of scientific pretense." Pigliucci and Boudry, eds. Philosophy of Pseudoscience, 68. ${ }^{398}$ Taylor, After God, 15.
} 
irony of your project is that the creation museum [sic] not only seeks to play the games of other discrete systems, but it is aggressively competing with some of those systems by appearing to use their vocabularies and structures directly." 399 This "appearance," as Aaron uses the term, is an effective piece of the effort to redefine science. For those who are not carefully attentive to the scientific vocabulary and to the broader syntactical methodologies of scientific fields, it is easy to assume the $\mathrm{CM}$ is giving just another viable scientific viewpoint.

For a non-specialist like me, reading the placards and texts in the Lucy exhibit sounded quite convincing. But when I entered conversations with paleoanthropologists and one anthropologist whose specialty is primatology, a vastly different explanation was given for the scientific consensus on Lucy. I am fortunate to have access to the resources of two universities with specialists who provide information that never come through at the CM. But for an average lay visitor, I am guessing it would require a significant effort to pursue other scientific opinions. Moreover, this assumes the visitor is even open to another interpretation.

The Lucy exhibit is a clear demonstration of the dynamics of interactive CANs. The scientific community has published widely and has made inroads into popular thought concerning the significance of Lucy. Her fossils, and many other Australopithecus fossils, have become important developments in the understanding of early hominids. The CM must give an answer to the scientific consensus on Lucy because this knowledge has been widely disseminated through textbooks, popular science

${ }^{399}$ David H. Aaron is Professor of Hebrew Bible and History of Interpretation, Hebrew Union College (Cincinnati, Ohio). He is currently writing a two-volume introduction applying information theory to the study of religious cultures. He has been exceptionally helpful to me as we have exchanged ideas and sources in this shared pursuit. David H. Aaron, e-mail message to author, November 12, 2013. 
magazines, and in mainstream news outlets. This example serves as an excellent illustration of how science impacts theology. Scientific theory challenges the religious myth because there are overlapping tasks at hand in both forms of discourse.

Theory (in the scientific sense of the word) and myth are two related concepts. They both tell stories which seek to explain facets of the experiential world. Taylor claims that, "While formally similar, theory and myth differ most significantly in their relation to time. Theory, on the one hand, abstracts from temporal development in an effort to determine universal truth, and myth, on the other, elaborates narratives to suggest general, if not universal, truths." ${ }^{, 400}$ Along these lines, I think it helpful to describe myths as timeless tales of human value. For example, the myth of Cain and Abel may stand as the prototype story of murder and jealousy, and of war and desire for power. Theory is in a constant and ongoing state of change or challenge. No scientific theory ever arrives. Some may gain the status of law, but even laws could potentially be challenged and overturned.

For religion and morality, myths have strength and enduring appeal if they speak wisdom into the complexities of human existence. A parable or myth does not depend on historical or scientific accuracy to be effective in establishing a moral or sapiential lesson. For example, Greek myths that caution against human hubris, like Sophocles' Oedipus Rex, are often wise lessons on the self-deceptions and potential danger of human pride. Further, whether the parable of the Good Samaritan ever happened is not at all important in establishing Jesus' point of what it means to be a good neighbor. The qualities of kindness and compassion that the Samaritan extends to the victim are as relevant today as they were in the time of Jesus.

${ }^{400}$ Taylor, The Moment of Complexity, 211. 
Scientific theory pushes to explain causality and to abstract naturalistic principles that explain physical phenomena. Such explanations inevitably employ narrative devices such as metaphor to communicate effectively. But in so doing, theory will often challenge the historicity of a religious myth. This is especially true when the myth departs from moral/ethical lessons and enters the realm of explaining physical phenomena. Ancient creation myths and myths about how the physical world interacts with God or gods are particularly susceptible to being overturned by modern science. The language itself has changed. For instance, we might still use the metaphor of a "sunrise," but we have lost the metaphor of the Egyptian deity, $R a$, hauling the sun across the heavenly sea in a boat. Likewise, the story of a global flood has some plausibility for the ancient Mesopotamian world that did experience devastating floods. But it must also be kept in mind that the ancients thought the whole world was much smaller and flatter than later science has established. Even though the late medieval church tried to reify the myth/theory of the earth as the unmoved center of everything, the bombardment of scientific information eventually became so overwhelming that the myth/theory was overturned completely.

Depending on what subject the myth is dealing with—such as how the physical world came to be — evolutionary science will provide one of the most threatening fields of study. As Taylor writes, "As different myths mingle and mix in a culture that is increasingly global, particular symbol systems and networks of myths are pushed to the edge of chaos where they either transform or collapse. ${ }^{״ 401}$ The CM's attempt to reinforce a myth results in the adoption of scientific language and imagery to show the visitor that

${ }^{401}$ Taylor, The Moment of Complexity, 214. 
the myth is stable. ${ }^{402}$ The result of such an approach is what scholars of science call pseudoscience because it attempts to present itself as legitimate science. ${ }^{403}$ Using the institution of a museum is a most effective means of doing this. Such effectiveness derives from an unquestioned prestige and authority granted to museums. In addition to the adoption of a scientific vocabulary and exhibit deigns like those of natural history museums, the CM employs all of the frames within the museum itself in order to pass muster as a legitimate institution. For example, it hires Ph.D. scientists to interpret and translate technical jargon for a lay crowd. The "new museology" of tech-savvy exhibits and interactive audio-video displays also work to project an image just like ones at mainstream secular exhibits. ${ }^{404}$

Because scientific theory and religious myths overlap in intention-i.e. in telling stories about the phenomenal world - they may be seen as the largest threats to one another. This need not be the case if one understands the tasks that each domain deals with. If seen as tales of the human struggle, myths may be powerful moral and spiritual paradigms that do endure as timeless tales of good and evil, right and wrong. Moreover, if science is seen as a methodological process of discovery and revision of natural processes, one would hesitate to use science an ultimate and unchanging epistemological foundationalism. Rather, the power of science is its flexibility and adaptability. The CM views science as a threat because it fails to recognize the primeval narratives of Genesis as myth. Subsequently, given the dynamics of the interplay of information, science is

\footnotetext{
${ }^{402}$ As is likely obvious, the CM does not believe their understanding of history and the Bible to be myth at all. They simply believe that they are using the best tools available to reify their story of the origin of everything.

${ }^{403}$ Pigliucci and Boudry, eds. Philosophy of Pseudoscience, 68.

${ }^{404}$ See Asma, "Risen Apes and Fallen Angels." Another term used to describe this new turn in museums is "edutainment." See also, Asma, Stuffed Animals and Pickled Heads, and Hein, The Museum in Transition.
} 
seen as the ultimate threat which seeks to destroy a faith that presses myth into literal history.

\section{Observational Science versus Historical Science}

As science is seen as a threat to YEC, another effort is made to redefine science by dividing it into two different pursuits. The two categories are called "operation science" and "origin science." In an interview with Terry Mortenson, this strategy was explained to me at length. The following definitions were written by Mortenson:

Operation (i.e., experimental, observational) science The use of observable, repeatable experiments in a controlled environment (e.g., a lab) to understand how things operate or function in the present physical universe in order to find cures for disease or produce new technology, etc.

Origin (i.e., historical science) The use of reliable, eyewitness testimony (if available) and observable evidence to determine the past, unobservable, unrepeatable event(s), which produced the observable evidence we see in the present. $^{405}$

Because something that occurred in the distant past cannot be directly observed in the present, the effort is made to place these long lost events in the realm of uncertainty. Scientists freely admit that there are always unanswered questions and that the events of the past ages of evolutionary history are speculative. But the CM seeks to use such uncertainty as a criticism of the fields of science that try to reconstruct how life has changed over time. The names given to those fields are origin or historical science. ${ }^{406}$

A wedge of doubt is inserted as a kind of philosophical sleight-of-hand in which uncertainty is presented as a weakness of evolutionary science. To support this assertion,

\footnotetext{
${ }^{405}$ These definitions were sent to me as a Microsoft Word document via e-mail correspondence from Terry Mortenson, a staff member at the CM who holds a Ph.D. in the History of Geology from Coventry University (UK). Terry Mortenson, e-mail message to author, Petersburg, KY, May 13, 2013.

${ }^{406}$ In a recent debate between Ken Ham and Bill Nye, which I attended and about which I have written a forthcoming essay, Nye pointed out that origin or historical science are not terms accepted by the secular scientific community. These divisions were thought up by young earth creationists. The Ham/Nye debate was held on February 4, 2014 at the Creation Museum, Petersburg, Kentucky.
} 
the $\mathrm{CM}$ uses quotations from prominent evolutionary scientists to demonstrate this position. The following quotation was included in the document sent to me by Dr. Mortenson. Ernst Mayr (1904-2005), one of the leading evolutionary scientists of the twentieth-century, has written:

Evolution is a historical process that cannot be proven by the same arguments and methods by which purely physical or functional phenomena can be documented. Evolution as a whole, and the explanation of particular evolutionary events, must be inferred from observations. ${ }^{407}$

There is the obvious truth that scientific reconstructions of the past are, as Mayr pointed out, beyond the realm of verifiability in the same way as that of the physical sciences such as chemistry and micro-biology.

As Mortenson explained to me, origin science follows a more legal set of investigative rules:

So I define origin science or historical science this way: It uses the legal historical method. Which is the use of reliable eye-witness testimony, if any is available, and observable evidence to determine the past, unobservable, unrepeatable events which produced the observable evidence in the present.

The main emphasis in CM literature and by staff members who hold terminal degrees in the sciences is that "true" science - to them, "true" means operational science onlymust be limited to only what can be repeated in the present. Because the evolutionary past is somewhat of a guess, they maintain that it should be placed into the philosophical or theological realm. The logic is that because there are so many unknown aspects of evolutionary history, one must bring in another authoritative magisterial voice to correct

${ }^{407}$ Ernst Mayr, What is Evolution? (New York: Basic Books, 2001), 13. Terry Mortenson, e-mail message to author, Petersburg, KY, May 13, 2013. 
the very questions that scientists ask. The Bible is presented as material evidence-a sort of artifact- of such an authoritative voice. ${ }^{408}$

As he defined origin/historical science, a great deal of emphasis was placed on reliable eyewitness testimony. This is to be expected as it does follow the legal and forensic approaches to establishing the validity of a past event such as a crime. When I asked Mortenson how the YEC model is different in kind from the whole Galileo Affair, he gave the following answer:

Mortenson: Well, I think there are two things. One is the Copernican model is dealing with operation science. The structure and the movement of the heavenly bodies. It's not dealing with the question of origins. So that's different. Secondly, there are some verses in the Bible that talk about the sun and the moon. But there's no clear description of the solar system in the Bible. And many of those statements are in the poetic literature where we expect non-literal, symbolic language. ... I'm not going to put my faith in science or in the majority view because the majority has been wrong many times.

Mortenson's response was informative of the CM effort to divide science into two fields - operation and origin. Pitting science into two categories allows for the insertion of doubt about things that happened in the past which cannot be witnessed and repeated in the present. The use of doubt is also reinforced by the reminders of how many times science has been wrong and subsequently revised with new paradigms.

The effort to present creationism and science on equal footing - that is, that both are unverifiable stories about history - is the central dichotomy which begins at the very first exhibit of the CM, Slot Canyon. The premise is explicitly stated in an AIG website article: "Both creation and evolution make claims about an unrepeatable past that was not

${ }^{408}$ Ella Butler has thoroughly explained the competing epistemological structures as presented at the CM. Commenting on this aspect of the Bible as the supreme artifact, she writes: "The second [CM's approach to understanding science] relies on the pre-interpretive status of the 'fact,' which positions the Bible, not as doctrine, but as artefact [sic]." "God is in the Data: Epistemologies of Knowledge at the Creation Museum," Ethnos, 75 (September 2010), 234. 
observed by humans. Thus both creation and evolution fall under the category of historical science. ${ }^{409}$ The epistemological move that achieves the most traction for fundamentalists and some evangelicals is the constant reminder that God's word (the Bible) is ultimate over everything else. Inerrancy becomes the epistemological key to everything. Because science changes, it cannot be ultimate in the sense that it is indubitably certain and without error. The Bible becomes the source needed to reinterpret everything that fallen humanity has misinterpreted. Butler identifies this epistemological move, "The Bible, in this sense, replaces the scientific method as the mediator between material evidence and ultimate interpretation." ${ }^{410}$

This effort to divide science into two different modes of investigation—operation and origin —is rejected by the scientific academy. ${ }^{411}$ Scientists conduct experiments frequently in trying to determine that age or past events that cannot be duplicated. Tree ring dating, ice cores, radio-isotope decay, distant starlight, and the study of fossil fuels all deal with non-repeatable, yet reliable, scientific dating methods. Moreover, these types of scientific pursuits are the most destabilizing to the YEC position. When I asked three of the Ph.D. staff scientists what were among the most significant challenges to their position, all three answered that both radiometric dating and distant starlight were the toughest challenges from a young-earth position.

This dividing of science into two domains, one testable and the other highly speculative, is effective at fooling many lay people. It does carry a certain common sense appeal. But professional scientists are not fooled. In an interview with evolutionary

${ }^{409}$ Answers in Genesis, http://www.answersingenesis.org/articles/2008/02/04/do-creationistsreject-science (accessed February 17, 2014).

${ }^{410}$ Butler, "God is in the Data," 241.

${ }^{411}$ Eugenie C. Scott, Evolution Verses Creationism: An Introduction, $2^{\text {nd }}$ ed. (Berkeley, CA: University of California Press, 2009), 292-97. 
biologist, Lindsey Walters, she explained that scientists often deal with information from the past that cannot be repeated or duplicated in the present moment. ${ }^{412}$ She also pointed out how creationists themselves rely on data that they cannot verify by direct observance-like the solar orbits of the earth or particle physics. But because science works with direct observation and inferences, the creationists must assert that the current laws and physics were not always the way they are today. To repeat one sentence from the interview with Mortenson, "I'm not going to put my faith in science or in the majority view because the majority has been wrong many times." The CM is counting on science being wrong about all of the theories involved with evolution. In fact, this has to be the case, otherwise the Bible is flawed and this, to them, means God is flawed. For the fundamentalist God/self/world schema, this is impossible. So all evidence-scientific and biblical—that challenges the CM's position is carefully screened out. The following section will demonstrate some of the many ways this screening process works.

${ }^{412}$ Lindsey Walters (Ph.D. Michigan State University) is Assistant Professor of Biology at Northern Kentucky University. She teaches courses on evolution for science majors and non-majors. 


\section{$\underline{\text { Screening Information }}$}

Screening information is a metaphor I have found helpful in approaching discourse and interpretation. As defined in Chapter II (pages 70-74), I use the term as a description of an aspect of information processing in open systems. ${ }^{413}$ Open systems use a process by which information is screened (or filtered) in order to construct manageable levels of data. This phenomenon is fractal in its proportionality. In other words, what happens on a micro-level also happens on a macro-level. ${ }^{414}$ Whether we screen background noise in a crowded bar to focus-in on a conversation with a friend or are sorting through copious notes in preparing a lecture, screening is always occurring as we process information. We must decide what information is most relevant to the success of a topic or task at hand.

The CM is both an open system and a CAN. It is open because it interacts with information from other systems — such as geology, biology, astronomy, and biblical studies. It is a CAN because it is always being influenced by outside data in other networks of information. It also adapts and changes to new information. ${ }^{415}$ Closed systems are actually quite rare, because it is difficult to limit new sources of information. Strictly speaking, a closed system is best exemplified my machines. An analog watch, for example, either works or does not work. It has no ability to process new information to

${ }^{413}$ An open system "means that the system can be influenced by its environment, just like a market might be affected by outside news about the earnings of a particular company - or the traffic is affected by the closure of a particular road," Neil Johnson, Simply Complexity: A Clear Guide to Complexity Theory (Oxford: Oneworld Publications, 2007), 14.

414 Taylor, After God, 21-22.

${ }^{415}$ In the early 1990s, Ken Ham used a picture, taken off the coast of Japan, to show a creature snagged on a fishing boat that he suggested might have been an actual plesiosaur (a form of sea going dinosaur). While the picture did look quite strange and bore a striking resemblance to ocean going dinosaurs, it was later shown to be the rotting carcass of a whale. The CM bookstore used to carry a book with a picture of the creature said to be a plesiosaur. That book is no longer offered for sale at the CM. The book was, Ian T. Taylor, In the Minds of Men: Darwin and the New World Order, $3^{\text {rd }}$ ed. (Toronto: TFE Publishing, 1994). 
adapt itself and to become a more accurate watch. But the CM attempts to function as a closed system by shaping all competing data in a very precise way. ${ }^{416}$ This dynamic tends to function in the vast majority of religious fundamentalisms. Taylor notes that "Religious reactionaries provide the clearest examples of the religiosity that absolutizes the relative by reifying or fetishizing a particular version of an emergent complex symbolic network."417

I have described these interpretive tendencies as "closed" approaches to hermeneutics (Chapter III). The CM would, if possible, remove all information that threatens or challenges its prevailing patterns or paradigms. The screening that occurs at the $\mathrm{CM}$ is one that attempts to keep-out any data/noise that threatens the pattern. In Taylor's terms, screening is the attempt to reify and fetishize the narratives of Genesis 111. In this section, I will explore the numerous ways in which information is screened in order to support a young-earth view of history. The preceding section-Observational Science versus Historical Science-may also be examples of screening information because it happens on so many levels.

\section{The CM Bookstore and Peer Review}

The CM's book and gift store, the Dragon Hall Bookstore, contains thousands of books, DVDs, magazines, toys, posters, and nearly every trinket imaginable that has something to do with YEC. Most of the volumes, although I could not get an exact statistic, are published by The New Leaf Publishing Group. The group offers three

\footnotetext{
${ }^{416}$ Taylor defines systems as closed in the following simple, yet helpful, definition. "Closed: Once established, they are not open to outside influences or sources of energy and information," Moment of Complexity, 79.

${ }^{417}$ Taylor, After God, 26.
} 
imprints: Attic Books, Master Books, and New Leaf Press. ${ }^{418}$ The vast majority of books at the CM bookstore are published by Master Books. According to the website, "Master Books is the world's largest publisher of creation-based material for all ages including apologetics, homeschool resources, reference titles, and quality children's literature. It is one of New Leaf Publishing Group's three imprints. ${ }^{, 419}$ Attic Books features mostly biographies on people such as Bishop James Ussher, George Washington, John Knox, and John Newton. "New Leaf Press offers a broad spectrum of inspirational titles for families and ministries including gift books, church leadership resources, and children's Bibles." 420

Most books in the store deal directly with issues pertaining to YEC and are classed as apologetics by theologians. Further, they fall into a narrow realm of presuppositional apologetics (PA) that are favored by conservative evangelicals and fundamentalists. ${ }^{421}$ While there are several differing viewpoints on PA, the CM claims to presuppose that the Bible is inspired and inerrant. Thus, everything which might call into question that premise must be explained or answered. ${ }^{422}$ An apology is given for why one believes a certain premise - although they are not "apologizing" in the common sense.

\footnotetext{
${ }^{418}$ New Leaf Publishing Group, http://www.nlpg.com/topic/biography (accessed February 27, 2014).

${ }^{419}$ New Leaf Publishing Group, http://www.nlpg.com/about-master-books/ (accessed February 27, 2014).

${ }^{420}$ New Leaf Publishing Group, http://www.nlpg.com/imprint/new-leaf-press (accessed February 27, 2014).

${ }^{421}$ See Molly Worthen, Apostles of Reason: The Crisis of Authority in American Evangelicalism (Oxford: Oxford University Press, 2014), 220-40.

${ }^{422}$ After having studied PA extensively throughout Protestant fundamentalism, I have found the approaches to be incredibly arbitrary. They almost always claim a presupposition of inerrancy, but they differ vastly on their interpretations of specific issues. At the CM, the real presupposition is not merely a view on inerrancy, but an even more rigid commitment to anti-evolutionism and to a young earth. I can cite numerous examples of positions on inerrancy that do not presuppose a young earth. J. Merrick, Stephen M. Garret, and Stanley N. Gundry, eds. Five Views on Biblical Inerrancy (Grand Rapids, MI: Zondervan, 2013). Moreover, I have found that particular presuppositions are usually rooted in some theological tradition in which one is raised or to which one converts.
} 
While there are hundreds of different titles, it is fascinating to me to see which books are not in the bookstore. Photo 5 (below) shows a relatively small set of books with the headings, "Classics and Sermons" (on the left) and "Bible and Study Tools" (on the right). ${ }^{423}$ With a biblical studies background, I'm immediately struck by the following observations. First, with the exceptions of the reprint editions of the Brown, Driver, and Briggs Hebrew and English Lexicon of the Old Testament, and several Bible translations, there are no other peer reviewed books - including conservative evangelical books. ${ }^{424}$ In the "Classics and Sermons" bookcase, the few biblical commentaries sold are Puritan reprints from the sixteenth-to-the-seventeenth centuries.

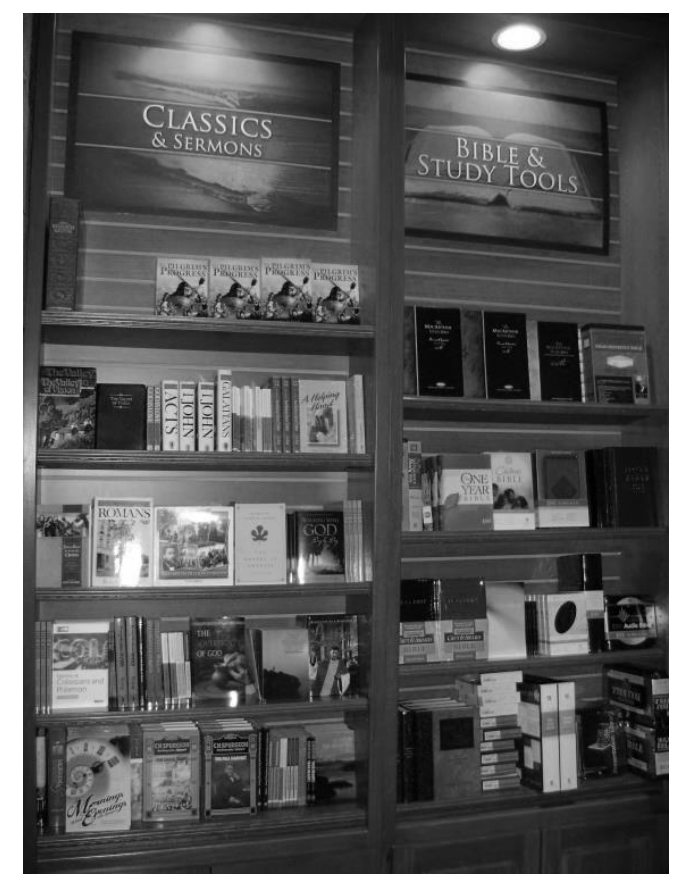

Photo 4. The CM Bookstore section on biblical studies. Photo: S. Watkins.

\footnotetext{
${ }^{423}$ Recently, the CM changed the title on the right to "Bibles and Study Tools," realizing that the singular use of "Bible" was not grammatically fitting.

${ }^{424}$ While this is an informal observation, I have never seen a BDB Hebrew Lexicon sold. I spoke with the bookstore manager and she said they sell about four lexicons per year. Most popular books at the CM can sell in excess of one-hundred copies per day. My guess is that there are few visitors who can read Hebrew and if they can, then they would have owned a copy of this volume for a long time as beginning Hebrew students must purchase a lexicon with a basic grammar for introductory courses.
} 
Second, the only Bible commentaries for sale address the epistles of Acts, Romans, Galatians, and 1 John. This seems peculiar since the museum deals almost exclusively with the primeval narratives of Genesis 1-11. The bookstore does sell the devotional commentary on Genesis by Henry Morris, but it is located in a different part of the store with the apologetics sources. ${ }^{425}$ There is a vast amount of peer-reviewed material available for the interpretation of Genesis. Much of the scholarship by conservative evangelicals such as Gordon J. Wenham, Kenneth A. Mathews, Derek Kidner, and Victor P. Hamilton — all of whom have full commentaries on Genesis - are not carried at the bookstore. Restricting such a wide body of scholarship is one example of how information is screened at the CM.

Third, this relatively small section of biblical study tools is a microcosm of the larger bookstore. For example, the bookstore is divided into sections. Some notable sections are as follows: "Dinosaurs," "Featured Best Sellers," “Answers Books," "Ken Ham," "Noah's Ark," "Family," "Science," "History," and "Curriculum." ${ }^{26}$ With the exceptions of Michael Behe's, Darwin's Black Box, and Phillip Johnson's, Darwin on Trial, there are no other books from other creationist positions. ${ }^{427}$ There was also a “Kid's Section” which contained toys, stuffed animals, books, DVDs, and other gift

${ }^{425}$ The Genesis commentary noted above is Henry M. Morris, The Genesis Record: A Scientific and Devotional Commentary on the Book of Beginnings (Grand Rapids, MI: Baker Book House, 1976). Morris was a committed fundamentalist who held a Ph.D. in hydrologic engineering. He had no graduate training in biblical studies. This is an example of stepping far outside one's own field of expertise. While this may be suitable for popular-level writing, it is also the main reason why I argue that this is not an academic/peer-reviewed commentary.

426 "Answers Books" refers to a four-volume series of books which seeks to answer common objections to YEC. They are titled The New Answers Book (volumes 1-4). Examples of the types of questions answered are: "Where did Cain get his wife?" "Does radiometric dating prove an old earth?" and "Why don't we find human and dinosaur fossils together?" The "Curriculum" section contained mostly home school curriculum that was published at Answers in Genesis. The "Ken Ham" section contains books written or edited exclusively by Ham.

${ }^{427}$ Michael J. Behe, Darwins Black Box: The Biochemical Challenge to Evolution (New York: The Free Press, 1996); and Phillip E. Johnson, Darwin On Trial (Downers Grove, IL: Intervarsity Press, 1993). 
items. But in all the sections I perused, nothing but materials from Answers in Genesis affiliated organizations was offered. Most titles were published by Master Books in Green Forest, Arkansas.

Screening out all competing books, including secular peer-reviewed and popular scientific books as well as the withholding of other evangelical books on varying versions of creationism, the $\mathrm{CM}$ effectively limits the amount of information that the visitor is exposed to. ${ }^{428}$ Also screened are mainstream academic biblical sources. The effort to control information is one of the CM's most creative adaptive moves. They had to produce a voluminous number of books and DVDs to make the bookstore appear to offer tons of information. However, as I have read the majority of these primary sources from nearly every category in the bookstore, I have found them to be quite repetitive. But if someone just looked at the shelves of books it appears that there is an overwhelming amount of data to be processed.

Fourth, even individual authors are screened. Charles Haddon Spurgeon (18341892) was one of England's most well-known Baptist preachers and orators. Spurgeon is a hero for many fundamentalists and evangelicals. He is known for his clever quips and retorts to skeptics of the Christian faith. The CM bookstore carries several of Spurgeon's books, however, I have never found any of Spurgeon's works that allude to his being an evolutionist. In the case of Spurgeon, his own writings are screened in order to suppress the idea that Spurgeon was an evolutionist as were nearly all early fundamentalists. ${ }^{429}$

${ }^{428}$ Excluded are books and articles by the following evangelical groups: The Biologos Foundation, Reasons to Believe, The Discovery Institute, and the American Scientific Affiliation.

${ }^{429}$ Early fundamentalists were overwhelmingly old-earth evolutionists. A position called the Gap Theory allowed for an interpretation of Genesis consistent with evolution and an old earth. This position was popular due to the high sales of the Scofield Study Bible. YEC did not become popular among fundamentalists until the release of Whitcomb and Morris, The Genesis Flood in 1961. See Ronald L. 
As mentioned earlier, peer-reviewed sources, whether biblical studies or sciences, are almost completely absent. It is understandable that a position as narrow as that held by the CM would call for limiting any exposure to a position that they have already decided was incorrect. But I was surprised to learn that they are making the effort to establish a peer-review process for YECs.

In 2008, Answers in Genesis launched a peer reviewed research journal titled Answers Research Journal. ${ }^{430}$ Every Ph.D. employee of the CM with whom I spoke recognized the need for peer review. However, when I asked if they could get YEC articles published in secular scientific journals they said that they could not. In my interview with Andrew Snelling, he elaborated on the peer-review process. ${ }^{431}$

Me: Is there any hope of getting your publications into the wider secular journals?

Snelling: Well it depends how it's framed. If papers we produce are framed in terms of looking at some scientific aspect and then applying it to the scriptures or looking at how it fits in the scriptures, then obviously that approach will only be deemed appropriate for publication in one of our own publications, where we've got this sympathetic acceptance of a biblical worldview.

Snelling went on to explain that if the editors of secular journals find out that one is a YEC (he used the word "background"), it has been his experience that they will not accept the article for consideration. This was the consensus of the other staff members who held research doctorates. As trained researchers, they know the value of the peer review process. I even got the sense from a couple of side comments that they tended to be a little bit insecure about the fact that they had not had any success in publishing YEC

Numbers, The Creationists: The Evolution of Scientific Creationism (Berkeley, CA: The University of California Press, 1992), 38-40.

${ }^{430}$ Answers Research Journal, http://www.answersingenesis.org/arj (accessed March 1, 2014).

${ }^{431}$ Andrew Snelling earned his Ph.D. in geology from the University of Sydney. 
articles in scientific journals. ${ }^{432}$ But they also spoke candidly about how YEC would never be published in secular journals. Snelling explained that what was required was a "sympathetic acceptance of a biblical worldview." The only sympathy for this world view is to be found among YECs.

An article in the first issue of the Answers Research Journal focused on explaining the YEC commitment to peer review. ${ }^{433}$ The article explained peer review as necessary because Christians have a moral obligation to be accurate with their information. ${ }^{434}$ Another justification for a YEC peer review process was based on criticism of the secular peer review process. The article began by citing numerous articles from secular journals such as the Journal of the American Medical Association and Science and Engineering Ethics. These articles explain cases in which the peer review process has been flawed and inaccurate. Similar to how the CM points to mistakes made in science, it begins by questioning and casting doubt on the reliability of current peer review.

After presenting peer review as a process that is in need of revising, the article explains why creationists need to develop their own peer review. "Since creationism differs from the conventional research community in important respects, we believe these differences warrant a different response to peer review." 435 Thus, Answers in Genesis developed the Answers Research Journal with Andrew Snelling serving as the current editor-in-chief. Two other YEC journals have also been established. First is the Creation

\footnotetext{
${ }^{432}$ It should be noted that all four Ph.D. scientists (Faulkner, Purdom, Snelling, and Menton) had published articles in secular journals. However, the articles dealt with some applied specialty and did not discuss creationism.

${ }^{433}$ Roger W. Sanders, Kurt P. Wise, Joseph W. Francis, and Todd Charles Wood, "Toward a Practical Theology of Peer Review," Answers Research Journal 1 (2008): 65-75.

${ }^{434}$ Ibid., 68.

435 Ibid., 67.
} 
Research Society Quarterly, published by the Creation Research Society. ${ }^{436}$ Second is the Journal of Creation, published by Creation Ministries International. ${ }^{437}$ These are the main journals for YECs and the ones with which Answers in Genesis interacts most frequently. The three different institutions all employ Ph.D. scientists in various fields. Danny Faulkner will be the new editor of the Creation Research Society Quarterly, even though it is separate from the CM. Other than the three creation organizations mentioned above, other writers and reviewers come from conservative evangelical and fundamentalist Bible colleges and seminaries. ${ }^{438}$

As I have elaborated above (page 73), proper peer review is a legitimate form of screening information. In other words, the goal of peer review is to ensure the credibility of a book, article, or research project. The goal is a "screening" out of lesser credible projects in favor of the most credible. The CM seeks to gain the status shared by the academy through forming its own peer review process. But I assert that it fails to achieve such a status because of several important blind spots.

First, the $\mathrm{CM}$ is trying to weigh-in on scientific observations but they are rigidly committed to a religious position first - namely, inerrancy. For Ham, the very existence of God is tied to a selectively literal reading of Genesis. This presupposition is more important than any scientific discovery. As I have endeavored to understand the CM reasoning, one must first adopt their interpretation of the earth as no older than sixthousand years. With that non-negotiable "starting point," the scientist must fit any and

\footnotetext{
${ }^{436}$ The Creation Research Society and its journal, Creation Research Society Quarterly, may be found at http://www.creationresearch.org/ (accessed March 1, 2014).

${ }^{437}$ Creation Ministries International and its journal, Journal of Creation, may be found at http://creation.com/ (accessed March 1, 2014).

${ }^{438}$ For example, the contributors to the article cited in footnote 430 are at the following institutions: Roger W. Sanders (Bryan College, Dayton, Tennessee), Kurt P. Wise (Truett-McConnell College, Cleveland, Georgia), Joseph W. Francis (The Master's College, Santa Clarita, California), and Todd Charles Wood (Bryan College, Dayton, Tennessee).
} 
all data into this framework. Dissonance is inevitable if radiometric dating and distant starlight — both items listed by informants as the two greatest challenges to YEC — appear to suggest a much older universe. But to insist on committing to a dogmatic religious position before applying the scientific method - a methodological naturalism- - seems to me to be not only fallacious, but also quite medieval.

Second, academic journals tend to stay focused on one field or sub-field of specialty. The Answers Research Journal is interdisciplinary in this respect. Articles published in the journal address a fairly wide range of subjects. For example, many articles appear to be limited to purely scientific discussions. ${ }^{439}$ One such article is titled "Implications of Polonium Radiohalos in Nested Plutons of the Tuolumne Intrusive Suite, Yosemite, California."440 Other articles are clearly addressing biblical, theological, philosophical, and ethical issues. I have used these four broad fields as a larger category of articles. The reason for this is that these subjects are highly intertwined in the topics they address. One such article that fits into this second broad category is "Can Theistic Evolution Explain the Origin of Morality?"441

When I compared the number of articles in the journals between these categories — scientific versus biblical, theological, philosophical, and ethical—it was interesting to note that about half of the articles (fifty-three) concerned scientific issues and the other half (fifty-one) addressed biblical, theological, philosophical, and ethical

\footnotetext{
${ }^{439}$ When I say "purely scientific," I do not mean that the secular scientific community would necessarily agree that the articles are pure science. But that is the intended category by the contributors to the journal.

${ }^{440}$ Andrew Snelling and Dallel Gates, "Implications of Polonium Radiohalos in Nested Plutons of the Tuolumne Intrusive Suite, Yosemite, California," Answers Research Journal 2 (2009): 53-78.

${ }^{441}$ Callie Joubert, "Can Theistic Evolution Explain the Origin of Morality?" Answers Research Journal 5 (2012): 25-37.
} 
issues. There were about seven articles that spoke to both realms listed above. ${ }^{442}$ An example of one such article is titled, "The Second Law of Thermodynamics and the Curse."443 I cite the article's abstract below in order to best summarize this merging of science with theology and ethics:

Many recent creationists believe that the second law of thermodynamics came into being as a result of the Fall or the curse. I argue that this is not supported by Scripture, nor is it a defensible position from a scientific viewpoint. Instituting the second law of thermodynamics at the Fall needlessly causes problems for theology and science. Rather, I propose that the second law of thermodynamics came into the picture during the Creation Week as part of the created order (Nehemiah 9:6; Colossians 1:16). ${ }^{444}$

At the CM, theology drives everything else. As Snelling tellingly admitted, publication would not be possible for someone who lacked "this sympathetic acceptance of a biblical worldview." By that, he didn't just mean a Christian worldview but a YEC worldview. The American Scientific Affiliation, a thoroughly evangelical group, would not publish YEC articles.

The mixing of different scientific and liberal arts fields also provides some interesting challenges for those attempting peer review. In an interview with Danny Faulkner, he explained a particular incident that he saw as problematic. He said that, as an editor, he usually requires three reviews before deciding to publish an article. However, six reviewers were required for a recent article he had written. Because he was dealing with science and biblical content, they needed three Hebrew language scholars to read the review for accurate use of Hebrew language in addition to the three scientific

\footnotetext{
${ }^{442}$ Strictly speaking, all of the articles—even the "scientific" ones—cross into the theological arena by default. As noted above, the pre-commitment to a dogmatic position of a young earth and antievolution are first and foremost theological and philosophical commitments, or "Starting Points" as labeled in the CM. This is one reason the secular scientific community finds it so frustrating to dialogue with YECs.

${ }^{443}$ Danny Faulkner, "The Second Law of Thermodynamics and the Curse," Answers Research Journal 6 (2013): 399-407.

${ }^{444}$ Ibid., 399.
} 
reviewers. The editor advised the Hebrew scholars to only comment on the Hebrew used in the paper and not the astronomy, for obvious reasons. The astronomers, conversely, were advised to comment only on the astronomy. A problem arose when the astronomers wanted to change a translation from the Bible that the Hebrew scholars had already unanimously vetted. Faulkner laughed as he explained how this was a case of the astronomers stepping outside of their field to influence a concept that they did not like. Once more, this illustrates how YEC scholars cannot escape importing theology into their science because the pre-commitment to a theological/religious schema precedes and outweighs the use of only empirical data.

The attempt to create peer review is yet another ironic aspect of how the CM ends up mimicking the very academy that it criticizes so sharply. While credentialed Ph.D. scientists who are also YECs are extremely few when compared with the number of secular scientists, they and their credentials are displayed prominently at the $\mathrm{CM}{ }^{445}$ In a recent debate between Ken Ham and Bill Nye, Ham used the strategy of playing video clips of credentialed scientists who were YECs. ${ }^{446}$ All of the scientists in the clips had impressive credentials. It was an effective way to cast doubt on the scientific community for a lay audience. At least, it presented the appearance that within the scientific community there is a major debate between YEC and evolution. There is actually no

${ }^{445}$ By "credentialed" I mean that they hold research doctorates from secular universities-like Purdom (Ohio State University), Snelling (University of Sydney), Faulkner (Indiana University), and Menton (Brown University). The Dragon Hall Bookstore contains many of the books authored by the scientists at the CM. Something I have noticed is the tendency to put "Dr." in front of the author's name on book covers and dust jackets. This is not a common practice for academic monographs. Rather, the author's biography usually contains their title and the institution at which they teach, in addition to some of their published books. Books that have "Dr." or "Ph.D." printed before or after the author's name are the following: Mortenson and Ury, eds., Coming to Grips with Genesis; Sarfati, Refuting Evolution; Sanford, Genetic Entropy and the Mystery of the Genome; and Faulkner, Universe by Design; etc.

${ }^{446}$ Ken Ham and Bill Nye, Uncensored Science: Bill Nye Debates Ken Ham, DVD, (Hebron, KY: Answers in Genesis, 2014). 
debate in the scientific community. The debate exists, as Nye pointed out, only in a very few YEC ministries such as the CM. The attempt to create a peer review process is an effective way to screen information while maintaining the image of academic rigor. This is also one more example of how powerful aspects of the academy have a direct influence on the CM. The irony is that the CM actually validates peer review by trying to form its own. But a trained scholar can easily see that such an effort will remain isolated from the larger academy. Its science becomes as closed a system as its hermeneutics.

\section{Screening Dinosaurs}

Perhaps the most iconic image in natural history museums is that of the dinosaur. Stephen Asma has documented the almost irrational love of dinosaurs by a museum going public. ${ }^{447}$ I informally questioned numerous people about this issue: "Why is the dinosaur used in advertising?" School teachers, children, business people, and family members all responded similarly that, "dinosaurs are popular," "dinosaurs are cool," “everyone likes dinosaurs," etc. Just out of further curiosity I used "Google" to search the question. Before I had completed typing my query, the following words appeared in the search engine: "Why are dinosaurs so popular?" This led to numerous explanations including the following:

On a recent road trip, I was discussing the SDMB with a friend of mine who is a librarian. "Whenever they have a program on dinosaurs at the library, they get completely swamped. Nothing else they do gets this kind of response. Boys and girls are nuts about dinos, so it's not gender based." 448

\footnotetext{
${ }^{447}$ Asma, Stuffed Animals and Pickled Heads, 226-27.
}

448 The Straight Dope, http://boards.straightdope.com/sdmb/showthread.php?t=85842 (accessed December 10, 2013). 
Several scholars in museum studies have also discussed the phenomenon of public love for dinosaurs. ${ }^{449}$

The CM has exploited the image of the dinosaur with two main goals in mind: as a marketing tool and as an apologetic strategy. When I asked Patrick Marsh, the artistic genius behind the design of the $\mathrm{CM}$, about this idea, he gave me the following response.

Me: Let me move on to dinosaurs. For a while around the tri-state there were billboards of dinosaurs and "Prepare to Believe." I'm asking visual and perceptual questions about the CM and there are stegosaurus on the walls as you approach and the dinosaur right in front of the door, etc. If there is a dominant theme...[Marsh began to answer before I completed the question]

Marsh: That's intentional. ..., all these museums basically talk about millions of years, millions of years, based upon dinosaurs you know, fossils, so it became the concept that we are going to take back the dinosaurs. We're going to show, you know, in our museum, feature dinosaurs in part because we have them but actually God used it to work it in a better way and because kids are fascinated with dinosaurs among other things. And it's just one of those little hooks to get them into the museum about the dinosaurs. So that's why we feature the dinosaurs because they really are a very good hook and we say that they were created at the very same time that all the other animals were created but we use it in a biblical way and it's just another way to get people into the museum and we had the collection that just became part of it.

Me: So they function as both a marketing angle and an apologetic angle?

Marsh: Absolutely. I mean it's all done apologetically. We've got kids books, "D is for Dinosaur," and all kinds of stuff that has been written about it.

Dinosaurs have been key to the advertising success of the CM even prior to construction.

In an article published in 2005, two years before the opening of the CM, Ham described a strategy for using dinosaurs as an "answer" to the secular scientific community.

Describing the intended use of dinosaurs, Ham wrote:

Children and adults alike are fascinated by these creatures. Unfortunately, most people equate dinosaurs with millions of years and the evolution belief system. Dinosaurs have become almost icons for evolutionary teaching - they're treated

${ }^{449}$ Sharon Macdonald, ed. A Companion to Museum Studies (Oxford: Wiley-Blackwell, 2011), 505, and Asma, Stuffed Animals and Pickled Heads, $226 \mathrm{ff}$. 
as sacred "gods" that belong only to evolutionists for their purpose of indoctrinating generations in secular humanism. This has occurred because the church — by and large - handed dinosaurs over to the "world" when they abandoned the literal history so clearly communicated in Genesis and allowed belief in millions of years and evolutionary ideas (like the big bang) to be taught to generations. Well, we want to put the evolutionary secular humanists on notice: we're taking dinosaurs back! ${ }^{450}$

In 2010, the CM rented billboards located in the greater Cincinnati and Northern

Kentucky area. Photo 6 (below) is one such example.

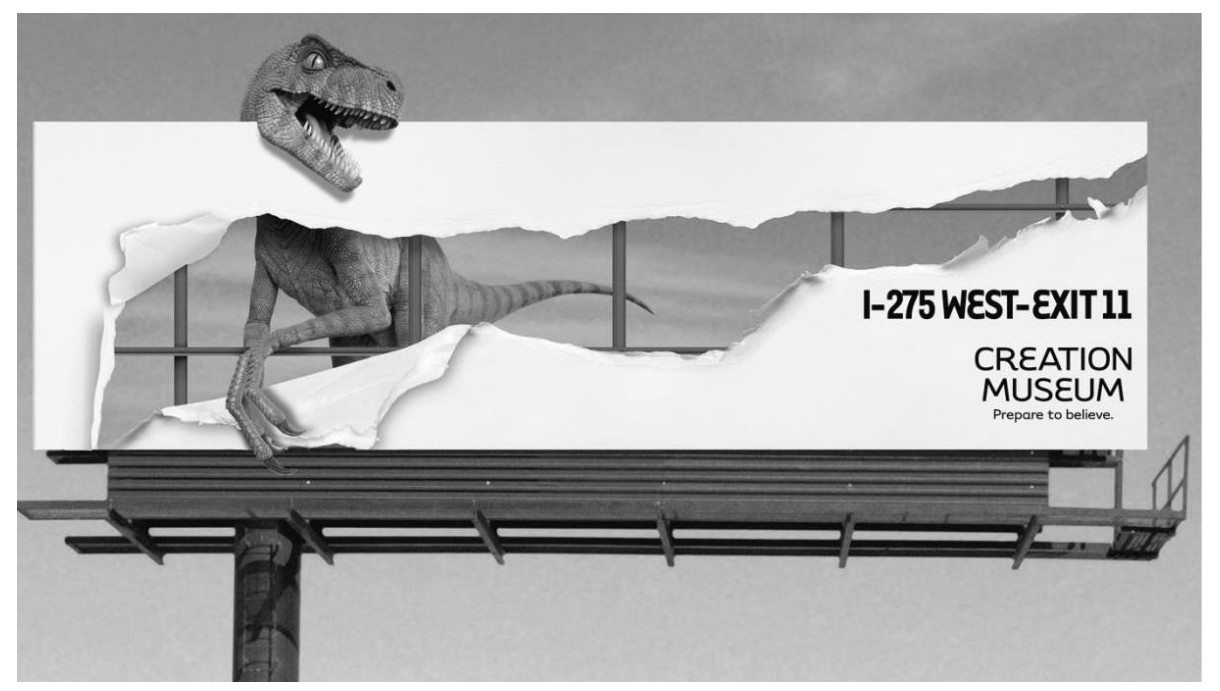

Photo 5. One of several billboards advertising the CM. Photo: S. Watkins

In each billboard, any of several dinosaurs are presented as ripping open an otherwise plain white billboard. The only other printed imagery on the billboards was the exit number and Interstate, the name "Creation Museum" and the logo, "Prepare to Believe." 451

With the dinosaur images and virtually no textual commentary, the billboard's message appears to be rather straight-forward: "Come see the dinosaurs." Nothing in a

${ }^{450}$ Ken Ham, "We’ve Invaded their Temple," Answers in Genesis, http://www.answersingenesis.org/articles/au/invaded-their-temple (accessed January 10, 2014).

${ }^{451}$ See Appendix, Photographs A, B and C. 
way suggestive of a young-earth is stated in the billboard for someone ignorant of the museum's content. The exception would be the word "creation." But there are so many viewpoints under the banner "creationist" that this term is not specific. The only other clue in the billboard is that something convincing will be presented. This insinuation is given in the motto, "Prepare to believe." The billboards were purchased in 2010 as a steady decline in visitors each year after the museum's opening in 2007.

Dinosaur images also appear as one approaches the main entrance to the parking lot. The metallic silhouette of a stegosaurus stands atop a stone wall with the words “Creation Museum” hanging below (Photo 7, below).

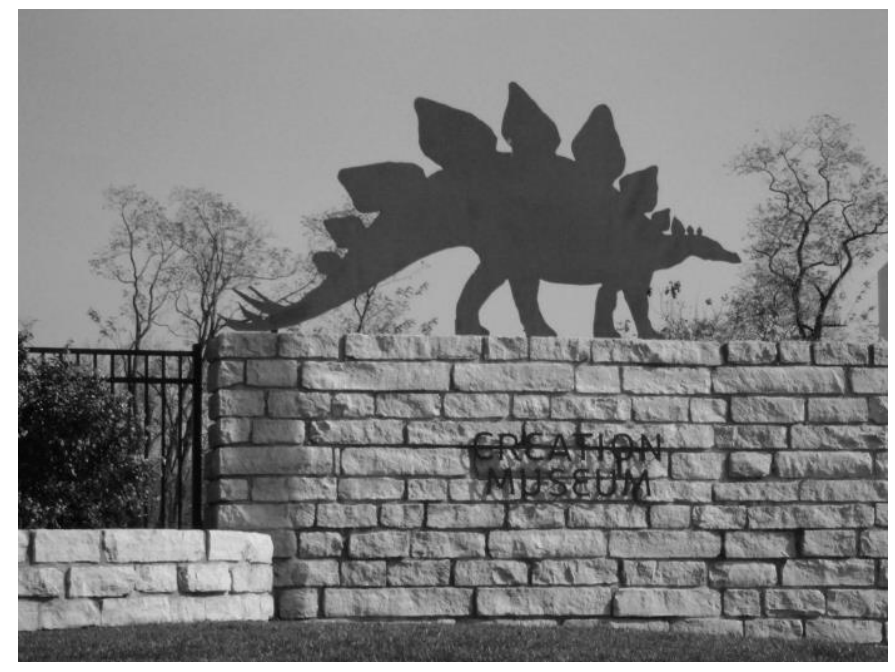

Photo 6. The stone wall adjacent to the parking entrance. Photo: S. Watkins As the visitor walks from the parking lot to the main entrance of the building, a pathway of white dinosaur footprints lead to a large, bronze-colored dinosaur located on the sidewalk adjacent to the main entrance. After entering the building a meandering foyer leads to a pterodactyl hanging from the ceiling with a photo booth where visitors may purchase a picture with a dinosaur. The main foyer, leading to the entrance of the 
museum contains the skeleton of a mastodon as well as several animatronic dinosaurs that are located next to the mannequins of fully evolved humans.

The marketing draw of dinosaurs is without question. But the apologetic strategy attempted by the CM is more complicated. Just as the famous Lucy fossils have become part of the public imagination, so too dinosaurs summon an almost magical past of distant evolutionary ages. It seems to irritate Ham that dinosaurs have become so iconic and connected to evolution. Once more, he makes this rather vitriolic connection clear: “[T]hey're [dinosaurs] treated as sacred 'gods' that belong only to evolutionists for their purpose of indoctrinating generations in secular humanism." 452 Given that the earth is only six-thousand years old, Ham must assert the notion that dinosaurs lived no longer than six-thousand years ago and possibly more recently than that. ${ }^{453}$

One of the most radical forms of revisionism that takes place at the $\mathrm{CM}$ is the effort to explain dinosaur fossils as recent. First, because God is said to have created all the land animals on the same day, dinosaurs had to have been created on that same day. A major tenet of the argument for Noah's global flood is that this single event "explains" the fossil record. ${ }^{454}$ Since scientists agree that fossils are indeed found in sedimentary rock layers, the fossils were thus formed at one time underwater. But the $\mathrm{CM}$ argument is that the fossils were produced rapidly in Noah's global flood in a forty day period of time. Noah's flood actually serves as a key explanation for such unorthodox claims. True believers in the CM message know that they must account for both dinosaurs and fossils.

\footnotetext{
452 Ken Ham, “We've Invaded their Temple," Answers in Genesis, http://www.answersingenesis.org/articles/au/invaded-their-temple (accessed January 10, 2014).

${ }^{453}$ Five-thousand years is required by Ham because he insists that, a) dinosaurs were aboard Noah's ark, and b) that Noah's flood was an actual event that took place approximately five-thousand years ago.

454 This argument was first made by John C. Whitcomb and Henry M. Morris in the landmark, young-earth book, The Genesis Flood: The Biblical Record and Its Scientific Implications (1961; repr. Phillipsburg, NJ: Presbyterian and Reformed Publishing, 1995).
} 
Thus a great deal of effort is put into the conceptualization of a realistic ship, capable of explaining how all those creatures actually survived the global deluge. ${ }^{455}$

Noah's flood and the portion of the main exhibit titled Flood Geology is the largest single section of the museum. Here, great efforts are made to present the great deluge as the mechanism which explains the rock layers and fossils. Tremendous amounts of water pressure, due to such a flood, is offered as the explanation for how fossils formed rapidly as dinosaurs and every other form of life were buried in a mass grave. Ham effectively uses a question when speaking to audiences. It has become his slogan. When he makes the assertion that the dinosaurs became fossilized during Noah's flood he states:

So how do you explain billions of dead things buried in rock layers, laid down by water all over the earth? If there was a global flood, you know what you would find? You'd expect to find billions of dead things buried in rock layers, laid down by water all over the earth. ${ }^{456}$

Dinosaurs present obvious challenges to YEC. But at every conceivable level, the CM offers answers to these difficulties. For example, when the obvious problem of how such enormous creatures could fit on the ark is asked, the CM replies that Noah likely took baby dinosaurs. After all, babies would be easier to handle anyway.

Another difficulty arises when we have no written account detailing the study of these large creatures. We do possess writings that are nearly as old as the time when the

${ }^{455}$ In the course of my research, Answers in Genesis announced plans to build the Ark Encounter, a one-hundred and fifty million dollar theme park in Grant County, Kentucky. It will contain a massive ark built on the specifications in Genesis. It is no coincidence that the ark would be the next project since such a key part of the rhetoric involves explaining dinosaurs on the ark.

http://arkencounter.com/?utm_source=aighomepage\&utm medium=banner\&utm campaign=ArkEncounter. KY, 2002). 
CM says Noah's flood took place. ${ }^{457}$ The CM ingeniously draws on the legends of dragons to explain dinosaurs. Ham writes:

Globally, there are many ancient descriptions and images of dragons. Interestingly, many of these descriptions and images are similar to drawings and depictions of how scientists believe dinosaurs would have looked. It makes sense: just as flood legends have a basis in a real event, dragon legends also have a basis in reality—-that people saw animals they called "dragons." 458

Located inside the lower level of the CM was a theater called the Dragon Theater. ${ }^{459}$ Every fifteen minutes, a video titled Dinosaurs and Dragon Legends is played. The tenminute video opens with a male narrator who tells the story of St. George the knight and the rescue of a maiden from a dragon. However, after summarizing the story, the narrator says "That's the legend of St. George the patron saint of England. A myth? Surely. An allegory filled with symbolism. But in the center of that myth is this strange creature. Where did such a creature come from?"460

The narrator begins transitions to the many legends of dragons from all over the world, Asian, Norse, European, etc. He lifts a Bible and quotes a passage from the book of Job: "Behold now behemoth, which I made with thee; he eateth grass as an ox. Lo now, his strength is in his loins, and his force is in the navel of his belly. He moveth his tail like a cedar. ${ }^{461}$ The video shows an interview with paleontologist Kurt Wise. ${ }^{462}$ Wise

${ }^{457}$ Samuel Noah Kramer asserts that based on Cuneiform documents from the area of ancient Sumer, writing probably developed in that area at the end of the forth millennium BCE, Samuel Noah Kramer, History Begins at Sumer: Twenty Seven “Firsts” in Man's Recorded History (New York: Doubleday Anchor Books, 1959).

${ }^{458}$ Ken Ham, "Were Dinosaurs Dragons?" Answers in Genesis, http://www.answersingenesis.org/articles/au/were-dinosaurs-dragons (accessed March 2, 2014).

459 The Dragon Theater was recently changed into a new exhibit called Dr. Crawley's Insectorium - a room devoted to an extensive collection of exotic insects from around the world. The video titled "Dinosaurs and Dragon Legends" was moved upstairs to the special effects theater.

${ }^{460}$ Dinosaurs and Dragon Legends, DVD, (Petersburg, KY: Answers in Genesis, 2007).

${ }^{461}$ Job 40:15-17 (King James Version).

${ }^{462}$ Kurt P. Wise is a YEC paleontologist who earned his Ph.D. under Stephen Jay Gould at Harvard University. 
states that the description in Job fits with a sauropod type dinosaur. Ham also connects the creature called behemoth in the Bible as a fitting description of a dinosaur.

Wise and Ham then read another passage from Job that describes another alleged dinosaur. "Canst thou draw out leviathan with an hook? or his tongue with a cord which thou lettest down? ... Out of his nostrils goeth smoke, as out of a seething pot or caldron. His breath kindleth coals, and a flame goeth out of his mouth." ${ }^{, 463}$ Wise suggests that the creature called leviathan may be a sea-going dinosaur, like a plesiosaur. The video closes with the narrator saying that we would expect tales of great beasts called dragons, if in fact dinosaurs and humans existed together.

While I struggle to take this idea seriously, on one level, I am struck at the irony that St. George (the legends of which could have been based on a historical knight) was said to surely be legend by the narrator. But the narrator suggests that the dragon was the reality immersed in the legend, not St. George. I have noted this happening in the literalized rendering of the Garden of Eden. A myth pressed into literal history creates other fictions. I have described how the serpent becomes a dragon-snake and the forbidden fruit is represented as grapes growing in a strange pod, on a tree-rather than on a vine. ${ }^{464}$ Efforts to literalize myths yield another layer of myths as St. George becomes the fiction and the dragon becomes an actual dinosaur.

The CM offers numerous reasons why dinosaurs could have lived recently. But in so doing, they must reject vast amounts of data from the scientific community. The fossil record itself is the most problematic aspect of their flood theory. Because all forms of life, so-called higher and lower forms, died at the same time, the burden for YECs is to

\footnotetext{
${ }^{463}$ Job 41:1; 20-21 (King James Version).

${ }^{464}$ Watkins, "Dragon Snakes and Fictitious Grapes," The Fourth R, 6-8.
} 
explain why lower forms were trapped in lower (hence older) rock layers and the higher ones were trapped in the highest rock layers - exactly as secular geologists and paleontologists have predicted. In the recent Nye/Ham debate, Nye asked Ham to produce one example of a human stuck in the same layer of rock as a dinosaur. That finding alone would potentially overturn the entire model.

Information about dinosaurs must be screened selectively in order to provide an alternative model based on a young earth. But instead of trying to avoid discussions of dinosaurs, the CM has effectively gone on the offensive. They are proud of their dinosaurs. Ham is bold to present his animatronic dinosaurs living right next to fully evolved humans. He writes, "To the humanists: we have invaded your evolutionary temples, and we have gone into your 'holy of holies.' We have captured the dinosaurs and we're taking them back to give them their rightful place in history! They don't belong to you!"465

\section{Conclusion}

As a CAN, the CM has effectively screened out massive data/noise from the interlaced fields of science and anthropology. Even though YEC is challenged by the scientific domains of knowledge, it remains a CAN. As such, it is robust and creative. Language itself may be thought of as a CAN. ${ }^{466}$ There are always new ways to explain phenomena. The CM employs the jargon of science as another screen that tries to make its ideas appear as real, rather than pseudoscience. Perhaps the CM is better at using jargon than are secular museums of natural history. Hilde Hein makes an astute

\footnotetext{
${ }^{465}$ Ken Ham, "We've Invaded their Temple," Answers in Genesis, http://www.answersingenesis.org/articles/au/invaded-their-temple (accessed January 10, 2014). ${ }^{466}$ Taylor, The Moment of Complexity, 215.
} 
observation in this respect: "Everyone loves dinosaurs, for example, but if numbers are a clue, museum visitors are as happy with cleverly engineered models that roar and move as with the carefully researched and reassembled paleobiological specimens found in traditional natural history museums. ${ }^{\not 467}$ Indeed, this is exactly what the CM excels at.

The United States has had a murky past with museums. Lest we forget P. T. Barnum's Fiji Mermaid at the American Museum in New York, museums that are adept at making money ought to be our first clue that something dubious may be going on. Once more, Hein sees a transition going on and offers the cautionary note: "Museums are drawing on the inherently spectacular nature of their resources and presenting themselves in a less linear and more theatrical manner." "E68 "Edutainment" is the term used by scholars in the field of museum studies to describe the money raising efforts which almost always have a dumbing-down aspect to knowledge. ${ }^{469}$ The $\mathrm{CM}$ is proficient at edutainment. It is no surprise to me that their next venture is the Ark Encounter theme park in Williamstown, Kentucky.

But the museum as a place of authority continues to loom large in our western democratic societies. In the course of my research on the $\mathrm{CM}$, the most helpful insights have come from three overlapping fields of current scholarship - hermeneutics, linguistics, and information theory. Borrowing from museum studies, S. Brent Plate comments on architecture and memory at the Jewish Museum in Berlin. I was impressed by the observation that a museum could potentially influence one's memory. In explaining the way our movement through the Jewish Museum helps us "to remember,"

\footnotetext{
${ }^{467}$ Hein, The Museum in Transition, 4.

${ }^{468}$ Ibid., 5.

${ }^{469}$ Asma, Stuffed Animals and Pickled Heads, 15.
} 
Plate described the powerful effect of architecture merging with memory in a similar way that I had already begun to piece together at the CM. Consider the following observation:

History, we may say, is learned through the head, memory through the feet. And it is architecture that provides a space to bring both together. Architecture provides a singular and unique medium for such memory; architecture, as Libeskind notes, "is public memory." And the architecture of the museum space may be seen even more so, especially in a secular age. ${ }^{470}$

The $\mathrm{CM}$ is seeking to establish and to reinforce a revisionist memory which, they claim, accords with both correct biblical interpretation and correct scientific interpretation. The amazing irony here is that the museum fails miserably in the area of biblical interpretation and science. But it provides an amazingly effective structure for creating and/or reinforcing "young-earth" memory.

The $\mathrm{CM}$ also provides such a disorienting amount of sensory data that the visitor feels overwhelmed. The interconnections of the data/noise that so engulf the visitor are hard to process, much less analyze. Taylor explains the complexity of networks of meaning that presciently describe the CM. "At the cusp of purpose and chance, words, images, and symbols are thrown together to create new meanings that are as unpredictable as they are uncontrollable. ${ }^{4471}$ Additionally, Taylor describes the attempts to stabilize myths: "The fewer the alternative points of view, the more stable particular patterns of explanation tend to remain. ${ }^{, 472}$ The $\mathrm{CM}$ attempts to reduce alternative points of view. For those people who want a closed system of meaning that is indubitably certain, biblical literalism has a powerful appeal. Yet because the reality is that CANs are

${ }^{470}$ S. Brent Plate, ed. Religion, Art and Visual Culture: A Cross-Cultural Reader (New York: Palgrave, 2002), 231.

${ }^{471}$ Taylor, The Moment of Complexity, 214.

${ }^{472}$ Ibid., 213. 
not closed, but open systems, a great amount of dissonance occurs from within these fundamentalist cultures that try to form secure enclaves.

With globalization and network society adding copious amounts of new data/noise, the time is most fertile for new and creative fundamentalisms to emerge. What Steven Pinker calls the "humanitarian revolution" refers to the progress that began in the second half of the eighteenth century. ${ }^{473}$ Humanism, he posits, is the result of a confluence of breakthroughs in tolerance, learning, printing, limiting authority, and listening. Yet, this humanizing force of good is the same force that threatens fundamentalisms. "The subversive power of the flow of information and people has never been lost on political and religious tyrants. This is why they suppress speech, writing, and association, and why democracies protect these channels in their bills of rights." ${ }^{474}$ This subversion of information, discussed in the concluding chapter, is two-sided in that it threatens and protects CANs. Ignorance of the dynamics of such a discursive and interpretive process may fuel the fundamentalist impulse to screen out the impure information and to preserve or reify a myth. Ironically, they end up destroying the power of the myth because it is forced to become something it can only pretend to be.

${ }^{473}$ Pinker uses the "humanitarian revolution" to describe the movement of humanism which lead eventually to the rise of secular democracies and the emphasis on individual human rights, Steven Pinker, The Better Angels of Our Nature: Why Violence Has Declined (New York: Viking, 2011).

${ }^{474}$ Ibid., 179-80. 


\section{CONCLUSION}

The $\mathrm{CM}$ is a fascinating example of the robustness and creativity exemplified in a complex adaptive network. One such example of this robustness is the recent Bill Nye and Ken Ham debate that drew millions of viewers online and over fifty different television, cable, and radio media. When I began my research on the CM in 2008, I had no idea how many changes would take place in the subsequent six years. The chapel was turned into a children's reading room; the foyer was transformed into a Dragon Legends exhibit; over a mile of zip-lines were erected on the multi-acre grounds; a proposed Ark Encounter theme park is underway in Grant County, Kentucky; Dr. Crawley’s Insectorium was installed in a previous theater; a Verbum Domini rare Bible exhibit was built adjacent to the Palm Plaza café; and a petting zoo was built on the far side of the CM campus.

The ability of the $\mathrm{CM}$ to adapt to new challenges and to raise money is impressive. The energy and friendliness of staff workers is also impressive. I have always gotten the impression that they were on a mission to succeed. The staff regularly works long hours for quite average wages. Even Ham's salary, less than two-hundred thousand dollars annually, is modest when compared with other CEO positions. A host of volunteers also contribute time for special events and programs. The CM is a cause that they believe in deeply. Fueled by Ham's impassioned pleas for doing God's work, one gets a sense that they feel that the very kingdom of God is at stake. "THERE IS A WAR 
GOING ON in society - a very real battle. The war is Christianity versus humanism.”,475 Dinosaurs must be rescued from the secularists. The church needs to return to biblical literalism — at least, as far as Genesis is concerned. For these religious devotees, heaven or hell is at stake.

When I began my research, I was not prepared to be as impressed as I was by what I found. By that I mean I did not expect the rigorous devotion to an epistemological structure that must be constantly reinforced. To quote theologian Stanley Hauerwas, "You have to be smart to be a fundamentalist." 476 The top tier leaders at the museum are both smart and creative. Numerous times, I have had to retreat to Northern Kentucky University to ask biologists, anthropologists, and paleoanthropologists for their rebuttals to the sophisticated spin I got at the CM.

However, my research has supported the central thesis, discussed in the Introduction, that the $\mathrm{CM}$ is a fundamentalist organization. While not all of my informants wanted this designation — most preferred the label "biblical Christian"-it is a fitting designation. The reason for this assertion is because the CM maintains a strict adherence to biblical inerrancy. Ham writes, "The acceptance of the literal events in Genesis is foundational to the question of biblical inerrancy."477 As Protestant fundamentalism has changed through the years, inerrancy has remained central in the attempt to establish an authoritative foundation for all knowledge.

Creating the need for an authority is equally important to fundamentalism. One key premise that supports inerrancy is the projection of a world that is rapidly declining.

${ }^{475}$ Ham, The Lie, 155.

${ }^{476}$ Office Hours with Stanley Hauerwas, Duke University, http://www.youtube.com/watch?v=fY7qL4pBN9I (accessed March 5, 2014).

${ }^{477}$ Ham, The Lie, 183. 
Through the use of the most horrific images, sounds, and created scenes - most notably in the Graffiti Alley, Culture-in-Crisis, and Cave of Sorrows exhibits - the modern world is shown to be the result of what happens when biblical authority is lost. Drug abuse, racism, pornography, totalitarianism, and many other social ills are presented as the inevitable outcome of a society not committed to the doctrine of inerrancy.

Inerrancy is also connected to the sin that brought down the human race. The sin of Eve and Adam, in other words, is equated with an attack on the ultimate authority (read inerrancy) of the Bible. As a literal and historical event, the sin committed by the primogenitor couple is transferred to anyone who doubts the six-day creation account. Every kind of moral and physical evil in the world was a result of this "attack on God's word." 478 The historical account in the Biblical Authority and Relevance rooms provides selective slices of those times when God's word is said to have been under attack.

The latest attack is that of evolutionary theory. Because evolution calls into question the historical and scientific accuracy of the primeval narratives of Genesis 1-11, it is presented as the actual force that is destroying the Christian church (see Photo 4, page 169) and American society (the Culture in Crisis exhibit). Thus, the "key to reclaiming the culture" is a selectively literal reading of Genesis. Genesis is offered as the foundation of the Christian way of life (see Figure 8, below).

${ }^{478}$ Ibid., 24. 


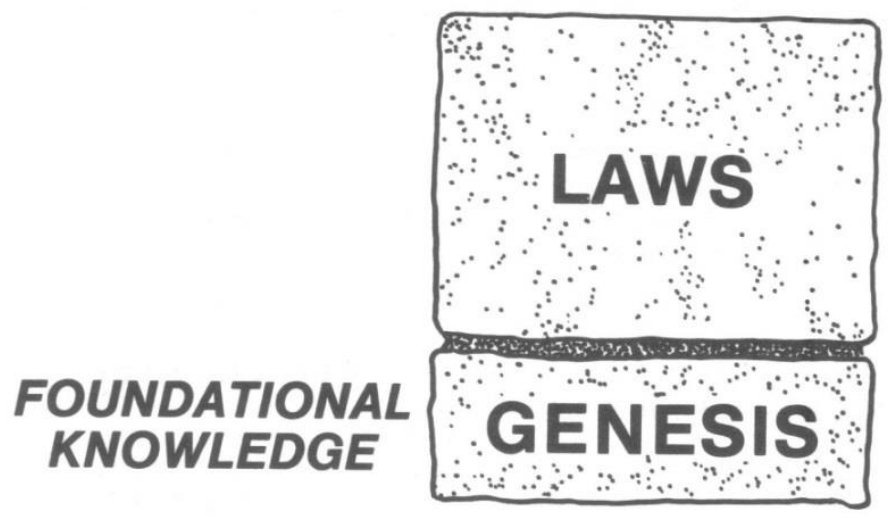

Figure 8. Ken Ham, The Lie, $1^{\text {st }}$ ed. 63.

The $\mathrm{CM}$ is effective at indexing any questions about the creation account in Genesis with an all-out assault on the Bible and on God. The results of such attacks are said to be the breakdown of morality, law, and other Christian institutions based on biblical precepts. Evolution does in fact challenge a young-earth and a historical and scientific interpretation of Genesis 1 . The CM is effective at forming an exclusive impasse. A dualistic dichotomy offers an either/or choice between evolution or the Bible. No other options are available.

The CM's effort to sustain biblical literalism and inerrancy requires an almost constant spinning of information to support a rather fragile set of premises.

Fundamentalisms often share the common denominator of a charismatic leader who is able to respond to competing information. Ken Ham is such a leader for the $\mathrm{CM}^{479} \mathrm{He}$ is definitely charismatic before most crowds. He is an articulate and persuasive speaker who often uses quips about his popular Australian accent and distinctive Amish-style

${ }^{479}$ In a recent discussion with anthropologist James Bielo, we both noticed the fact that Ham tends to be winsome and charismatic before crowds and on camera, but in person he often seems withdrawn, quiet, and serious. It was this way in my interview as well. However, he had just returned from Australia the day before and seemed completely drained of energy. I do not see Ham as a gregarious, jovial, and personable leader such as Jerry Falwell, Billy Graham, Charles Swindoll, or Pat Robertson. But his charisma does show through before an audience. 
beard. In an address to Bellevue Baptist Church, he told the crowd that he had been told that, "He looked like Abraham Lincoln and talked like Crocodile Dundee."480 The response was laughter and some applause.

In addition to being an effective communicator, Ham's real talent is in organization building and raising money. He seems to possess the ability to convince people that his interpretations are the right ones and is able to instill confidence in staff members and followers. In numerous of my interviews, CM staff members would pause at certain questions and often give a response such as, "Well, Ken would say this," or "Ken sees it this way." Ham has been able to communicate a vision that his followers believe is important in order to maintain the Christian way of life.

In my study of fundamentalist culture, the charismatic leader is the single most important part of the organization. The leader must spin competing data in a never ending struggle to make sense of the group's internal logic and identity, no matter how much outside information may challenge such claims. Additionally, the leader must constantly convince his followers that their cause is the highest and most important cause. Ham convinces his followers that interpreting Genesis in a selectively literal way is the key, not only to "reclaiming the culture," but also in affirming God's word as an act of obedience in and of itself. For these believers, trusting a six-day creation account which occurred only six-thousand years ago is an act of obedience that pleases God. This belief is said to be even more important than the bodily resurrection of Jesus or the virgin birth because Genesis is part of the same book as the New Testament gospels. Ham opines, "If

${ }^{480}$ Ken Ham, Genesis, DVD. 
God did not mean what he said in Genesis, then how could one trust Him in the rest of the Scriptures?",481

At the end of the day, an organization like the CM must raise millions of dollars of revenue. For a fundamentalist God/self/world schema, this usually consists of the leader convincing his followers that his cause is the greatest threat to Christianity and to the collapse of "Christian" society. ${ }^{482}$ Ham is able to use the decreasing numbers of traditional Christian church attendance in the United States as an example of why his cause is so important. According to him, if the church could erase the idea of evolution, the world would return to trusting the Bible and all of our social problems would fix themselves. Such a need or sentiment is also a strong part of fundamentalism. There is always a strong desire to return to a simpler, more pure, and safe past. The myth of a "golden age" sells well to religious people who feel threatened by the complexities of modernity. Several scholars have predicted that the increase in connectivity and globalization will only add to the desire for fundamentalist societies who promise to resist increasing complexity. ${ }^{483}$

In the Introduction, I listed several guiding questions that I wanted to answer in the course of my research. I will explain the summary answers that have emerged in the three main chapters of analysis (Chapters III, IV, and V). The first question sought to

\footnotetext{
${ }^{481}$ Ham, The Lie, 17.

482 "Christian" society is a highly flexible and constructed term. Ham uses the term in a fluid way, but usually insists on a time when a higher percentage of Americans attended traditional church services and prior to any number of social issues-i.e. the legalization of abortion, the repeal of “Don't Ask Don't Tell," and the prohibition on prayer in public school, etc.

${ }^{483}$ Manuel Castells, The Rise of the Network Society, Vol. 1 of The Information Age: Economy, Society, and Culture, $2^{\text {nd }}$ ed. (Malden, MA: Wiley-Blackwell, 2010); Olivier Roy, Holy Ignorance: When Religion and Culture Part Ways, trans. Ros Schwartz (New York: Columbia University Press, 2010); Mark C. Taylor, After God (Chicago: The University of Chicago Press, 2007); Peter Berger and Anton Zijderveld, In Praise of Doubt (New York: Harper One, 2009).
} 
explain how the CM structured a cohesive but revisionist/concordist Bible narrative in the exhibits and media forms present at the museum. My research shows that concordism-a hermeneutic approach that involves reading an ancient text with a modern scientific understanding - is the driving interpretive premise. The version of biblical inerrancy espoused that the CM is so rigid that every description in the Bible must accord with reality as we currently understand it. Coherence is maintained by the inserted premise that if the Bible is wrong about science and history, than it is wrong about everything else and must be discarded. The hermeneutic approach is quite closed because it assumes a category of absolute truth that fails to acknowledge the difference in historical horizonsto use Gadamer's term. For lay persons, it is hard to catch the layers of meaning that have crept in throughout Christian history of interpretation. A basic awareness of such interpretive layers requires hundreds of pages of careful reading. In this respect, the CM has simplicity on its side.

Second was the question concerning whether or not YEC has become one of the new movements within fundamentalism. As explained in the opening section of this Conclusion, inerrancy, either/or dualism, desire for a return to a moral/better age, and Ham as a charismatic leader, all qualify the $\mathrm{CM}$ as a thoroughly fundamentalist institution. Further, I have documented several exhibits and lectures at the CM to have been sponsored by Bob Jones University—one of the most openly fundamentalist institutions in the country ${ }^{484}$ Moreover, every indicator is that YEC is on the rise. ${ }^{485}$ Much of the Dragon Hall bookstore material includes home-schooling curriculum. A

${ }^{484}$ Bob Jones recruiting materials are located on a stand toward the end of the museum's main exhibit. One color brochure is titled, "Build Faith. Challenge Potential. Follow Christ. Bob Jones University." One large display board advertised a lecture by David Menton titled, "The Truth." The lecture was sponsored by Bob Jones University. Documented in a personal photo.

${ }^{485}$ Scott, Evolution Verses Creationism, 110. 
large percentage of visitors are independent, non-denominational fundamentalists who are devoted to the home schooling movement. ${ }^{486}$

One new facet of fundamentalism at the CM is the fact that they have distanced themselves from traditional dispensational theology. Dispensational theology had been a central feature of Protestant fundamentalism through the twentieth-century. John Whitcomb and Henry Morris were both staunch dispensationalists. In my interview with Ham, he explained that many doctrinal beliefs are not put forth as important issues.

Ham: For AIG, we don't deal with issues of baptism, modes of baptism. We don't deal with eschatology. Except that Jesus is coming back again. But not certain positions like a-mil, post-mil, pre-mil. ${ }^{487}$ And we don't deal with translation issues, King James only or Sabbath day issues. I just like to say we're biblical creationists.

Fundamentalists and evangelicals have also become innovative in the use of technology and media. My appraisal of the recent Ham/Nye debate is that the CM stood as the side which gained the most from the debate. The technology was better on Ham's side. ${ }^{488}$ The debate almost instantly became the number one trend on Twitter while the debate was still underway. This publicity led to hundreds of thousands of increased website visits for Answers in Genesis. Further, elevating YEC to a stage as well-known as Bill Nye presents the notion that there really is a debate among scientists as to the legitimacy of a young-earth. Seated in the front row of the debate and supporting the position of Ham was R. Albert Mohler, president of the Southern Baptist Theological

${ }^{486}$ I spoke with Dan Mangus (Senior Director of Museum Operations). He expressed that he had no way of documenting the demographics of visitors. But on many visits I saw church busses and vans from these independent, churches - some of which I recognized as local fundamentalist churches in the Northern Kentucky area. To be fair, there were also a high percentage of Amish and Mennonite visitors.

${ }^{487} \mathrm{Ham}$ is referring to the three different eschatological positions known (respectively in the order given above) as a-millennialism, post-millennialism, and pre-millennialism. Pre-millennialism is the sphere of dispensational theology which posits a bodily return of Jesus to earth to usher in a one-thousand year kingdom on earth.

${ }^{488}$ Steve Watkins, "Ken Ham Bill Nye Debate," Reports for the National Center for Science Education, (forthcoming). 
Seminary, in Louisville, Kentucky. Moeller has been identified as a new leader in the fundamentalist resurgence of the Southern Baptist Convention.

Another question addressed by my research asks how the CM uses language, interpretation, and imagery to uphold biblical literalism. Biblical literalism, or "Biblicism," is presented as a non-negotiable Starting Point at the museum. ${ }^{489}$ Presuming that the Bible is an inerrant guide to certainty is that Starting Point. The question above is best answered by my research in Chapter IV. Evil is explained as the inevitable result of using anything other than a literal reading of Genesis. Any other interpretation, metaphorical or mythical, is seen as a form of disobedience. The maintenance of such a position is accomplished through authoritative scripts or voices at various places - the scientist, the professor, the anointed preacher. These scripts fit with places or frames of expected authority, such as the planetarium, lecture hall, or pulpit. Interpreted texts (especially Genesis), and fossils, scenes of mayhem and disorder are all fit into a metanarrative that explains the world in terms of a dualistic struggle between the saved and the dammed. A dualistic God/self/world schema that sees God as transcendent is necessary for such a world to cohere.

The question concerning the degree to which evolutionary science is portrayed at the $\mathrm{CM}$ is rather complex. First, evolutionary science as an explanatory model of the development of human life is rejected completely. However, certain forms of so-called "micro-evolution" are accepted. They posit that all current species of animals derived from some proto-kind of animal. These "biblical kinds" of animals are said to be roughly

\footnotetext{
${ }^{489}$ The following sources explore the many manifestations of evangelical and fundamentalist biblicism: Bielo, ed., The Social Life of Scriptures; Malley, How the Bible Works; and Christian Smith, The Bible Made Impossible: Why Biblicism is Not a Truly Evangelical Reading of Scripture (Grand Rapids, MI: Brazos Press, 2012).
} 
equivalent to the family level of taxonomic categorization. ${ }^{490}$ However, the amount of change required for roughly two-thousand proto families of animals to change into the current number of species (land vertebrates alone) is vast. According to Lindsey Walters (biologist), there is no possible way such alleged changes could have occurred in fivethousand years. In my judgment, the model that the CM call science is better labeled pseudoscience.

The question of how information is screened is explored most thoroughly in Chapter V. Information is screened on numerous levels and in ways that are sometimes intentional and sometimes unintentional. The withholding of a vast array of scholarshipscientific and biblical —in the bookstore is the best example of intentional screening. Unintentional forms are harder to identify because every aspect of imagery would require an exhaustive questioning process to determine all aspects of intentionality. However, I suspect that historical anachronisms such as Aramaic Hebrew script on tablets carried by Moses are unintentional as they would embarrass someone familiar with biblical Hebrew and its historic development. Another such example is the presentation of a rolling stone placed on the Garden Tomb in Jerusalem (see Photo 7 below).

${ }^{490}$ Bill Nye, Ken Ham, Uncensored Science, DVD. 


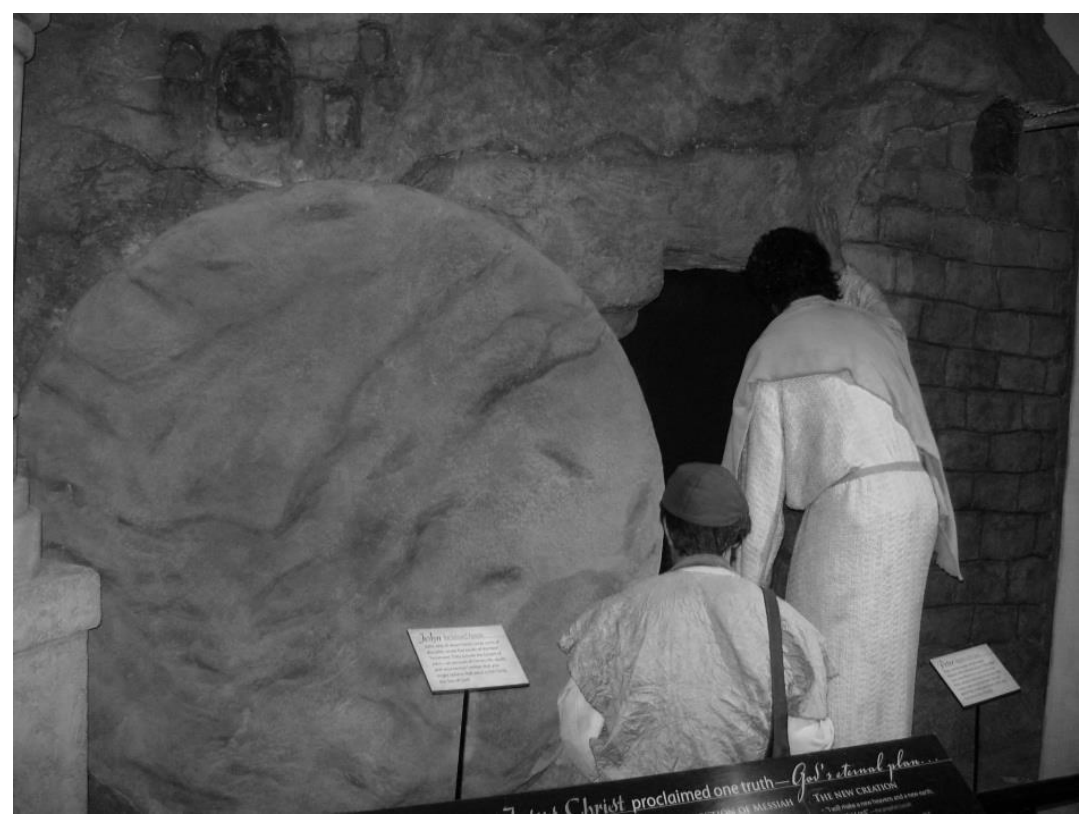

Photo 7. The Garden Tomb with a Rolling Stone Door. Photo: S. Watkins

These anachronisms are historically inaccurate. With all the effort to make biblical history as accurate as possible, my only conclusion is that these anachronisms must have been unintentional.

The question as to demographic and denominational statistics on visitors has been difficult to document. The Senior Director of Museum Operations, Dan Mangus, communicated to me that there was no way to provide accurate metrics of visitor demographics because there is no measure in place to identify this data. The closest measures are visitor feedback cards that some people choose to fill out. But these are highly subjective and selective. In my visits, the crowds have been overwhelmingly white and middle class. I base this on automobiles, physical appearances, clothing, and the informal conversations that I have overheard. Denominationally, it is hard to say what, if any, single group is in the majority. I would guess Baptist, but that is a broad category on its own. Many non-denominational, Community and Bible church busses are regularly parked in the visitor parking lot. There are a significant number of Amish and Mennonite 
visitors. I cannot recall a time when I have never seen at least some Amish and/or Mennonite visitors. Mr. Mangus estimated between ten and twenty percent of visitors were from the Amish and Mennonite communities.

The core premise that enables the CM's view of the world to be understood and accepted is a particular and narrow doctrine of biblical inerrancy. Unflinching commitment to this dogma is the single epistemological requirement in order for the message to cohere. All of the problems in the world, including evolution, are explained through the lens of this particular form of inerrancy. Ham's interpretation becomes the authoritative voice that puts all of secular science in its place. Ham's words become God's words. This commitment to indubitable certainty seems to satisfy millions of people. As long as information is screened properly, coupled with a dualistic God/self/world schema, the message appears to make sense to many, otherwise intelligent and educated, people. However, I would predict that most do not hold advanced science (especially geology and biology) or biblical studies degrees.

The CM functions as a CAN for several reasons. It is an open system. Interaction with the outside world is inevitable for many reasons. The most obvious is the organizations fervent use of internet media. The Ham/Nye debate was the result of a Youtube post that went viral. Second, the museum is threatened by competing new data/noise from intersecting fields-technology, theology, science, psychology, etc. Third, the museum is both robust and creative. Even with massive competing data/noise, Ham and his creative team continue to provide causes and attractions that bring in copious amounts of money. However, because the CM is an open system that tries to be closed, a number of inherent ironies emerge. 
$\underline{\text { Irony }}$

How wonderful we have met with a paradox. Now we have some hope of making progress. - Neils Bohr ${ }^{491}$

In six years of research at the CM, I have traversed an emotional spectrum ranging from anger to an almost giddy delight. In the past year, paradoxical themes continue to emerge at so many levels. If Taylor's descriptions of the dynamics of CAN's are accurate, as I judge them to be, we would expect the CM to produce paradox as it seeks to establish order out of disorder. Taylor writes, "Finally, order and disorder are not simply opposite but are codependent in such a way that neither can be what it is apart from the other." ${ }^{, 492}$ The irony I see most clearly is that in trying to resist the academic communities that most threaten it—biblical and scientific studies - the CM becomes a mirror image of those same institutions. It taps into the vocabulary of science, yet creates its own semantic appropriation of those terms. It hires scientists with academic credentials, builds lecture halls and planetariums. Indeed, the museum itself is an institutional idea that is closely connected with the academy.

Further, in the attempts to historicize the ancient myths of Genesis, it ends up creating fictions of its own. My essay on the production of dragon-headed snakes and grapes growing on trees are two examples. ${ }^{493}$ The attempt to place myth into an historically verifiable realm creates the ironic outcome of forming a new myth. As I understand it, the myth of the origins of good and evil (The Garden of Eden) should remain a timeless tale of wisdom for humanity. Seen this way, myth becomes a powerful moral story rather than a fictitious parody.

\footnotetext{
${ }^{491}$ Quoted in Ruth Moore, Niels Bohr: The Man, His Science, \& the World They Changed, $1^{\text {st }}$ ed.(New York: Alfred A. Knopf, 1966), 196.

492 Taylor, After God, 15.

${ }^{493}$ Watkins, "Dragon Snakes and Fictitious Grapes," The Fourth R, 6-8.
} 
Another paradoxical outcome of the position held by the CM involves an interpretive dilemma. The Bible is said to be infallible and inerrant. As such, it is put forth as the authority on all matters to which it refers. However, the Achilles heel of this assertion is that, for the Bible to be authoritative, it would also require an infallible and inerrant interpreter. Leaders such as Ham must appeal to a common-sense level of reading in order to conceal this interpretive problem. They claim ideas such as the perspicuity of scripture to ensure that average, non-specialists can interpret the text as easily and clearly as scholars who hold graduate degrees in theology and biblical studies. But Ham must also be careful to avoid the vast differences in interpretation even among YECs. Kathleen Boone has documented this tendency by fundamentalist leaders to avoid such topics. "Only by concealing their role as interpreters are fundamentalist authorities able to wield their immense power over ordinary believers." ${ }^{494}$ Ironic too, is the fact that the doctrine of total depravity, held strongly by Ham, suggests that humans are more likely to be fallible.

Screening, as it has been discussed above, is a fitting way to describe the filtering aspects of the presentations of the modern world as a threatening and declining place. The scenes of modernity at the CM's main exhibits include Graffiti Alley, Culture in Crisis, and the Cave of Sorrows. These are extremely negative (even racist) slices of modern society. One wonders what a medieval alley would have looked like. I would suggest that such a place would be far worse than an inner city area-especially during the Black Plague. Drugs, abortion, atomic weaponry, genocide, pornography, and other social concerns are but one limited part of the modern world. What about sanitation, beautiful zoos and parks, research medical hospitals, increased life spans, all time low

\footnotetext{
${ }^{494}$ Boone, The Bible Tells Them So, 95.
} 
crime rates? Agreeing with Steven Pinker, it seems that so much good in the modern world is suppressed. At the same time, in the Wonders of Creation room, beautiful photos and videos of nature scenes are presented as classical music plays in the background. The association is cast just after a visitor views the Six Days of Creation video-an account that asserts how the world really began. These are all pictures of the modern world as good and beautiful. Obviously, there is good and bad in the world. But much of the good of the modern world is highly screened and used only when a positive association is needed.

The last item of paradoxical outcome concerns the physical reality of the world as scientists now understand it. Astronomer Danny Faulkner affirmed that he believed the distances (including the red shift phenomenon) of the stars are in accordance with the current Big Bang model. He disagreed that the Big Bang caused the current state of the cosmos. Faulkner agreed with the distances and measurements of secular astronomy. But these scientific models change, as the CM makes a concerted effort to point out. Steady State theory has been replaced by the Big Bang theory for the vast majority of astronomers. Yet, the scientists at the $\mathrm{CM}$ work vigorously with scientific categories in order to harmonize them with the ancient creation myths of Genesis. Because they believe the ancient record to be one-hundred percent accurate, I find it rather ironic that changing models are applied to something supposedly unchanging.

It would seem that the lesson of the Galileo Affair should allow the freedom for YEC to hold loosely to any scientific model. On the other hand, science must be answered because the CM remains connected to epistemological systems that constantly 
revise current interpretations. While it wants desperately to be a discrete and closed system, it is forced to co-evolve as a complex adaptive network. 


\section{REFERENCES}

Primary Sources

Answers in Genesis. Homepage. http://www.answersingenesis.org (accessed 17 October, 2010).

Answers in Genesis, Journey Through the Creation Museum. Green Forest, AR: Master Books, 2008.

Answers in Genesis. The Creation Museum: Behind the Scenes. Hebron, KY: Answers in Genesis, 2008.

Behe, Michael J. Darwins Black Box: The Biochemical Challenge to Evolution. New York: The Free Press, 1996.

Creation Museum. Homepage. http://www.creationmuseum.org (accessed 17 October, 2010).

Dooley, Tom. The True Story of Noah's Ark. Illustrated by Bill Looney. Green Forest, AZ: Master Books, 2003.

Edwards, Brian H. Nothing But the Truth: The Inspiration, Authority and History of the Bible Explained. Darlington, England: Evangelical Press, 2006.

Faulkner, Danny. Universe By Design: An Explanation of Cosmology and Creation. Green Forest, AR: Master Books, 2004.

Ham, Ken. Genesis: The Key to Reclaiming the Culture. DVD. Florence, KY: Answers in Genesis, 2002.

Ham, Ken. The Lie: Evolution. El Cajon, California: Master Books, 1987. 
Ham, Ken. The Lie: Evolution/Millions of Years. Rev. ed. Green Forest, AR: Master Books, 2012.

Ham, Ken ed. The New Answers Book: 1. Green Forest, AR: Master Books, 2006. . The New Answers Book: 2. Green Forest, AR: Master Books, 2008. . The New Answers Book: 3. Green Forest, AR: Master Books, 2010.

Ham, Ken and Bodie Hodge eds. How Do We Know the Bible is True? Vol. 1, Green Forest, AZ:Master Books, 2011.

_. Begin: A Journey Through Scriptures for Seekers and New Believers. Green Forest, AZ: Master Books, 2011.

_. How Do We Know the Bible is True? Vol. 2, Green Forest,AZ:

Master Books, 2012.

Ham, Ken, Carl Wieland and Don Batten. One Blood: The Biblical Answer to Racism. English Standard Version. Green Forest AR: Master Books, 1999.

Johnson, Phillip E. Darwin On Trial. Downers Grove, IL: Intervarsity Press, 1993.

Morris, Henry M. The Genesis Record: A Scientific and Devotional Commentary on the book of Beginnings. Grand Rapids: Baker Books, 1976.

_. The Biblical Basis for Modern Science. Grand Rapids: Baker Book House, 1984.

Morris, John D. The Young Earth. Colorado Springs: Master Books, 1994.

Nye, Bill and Ken Ham. Uncensored Science: Bill Nye Debates Ken Ham, DVD.

Hebron, KY: Answers in Genesis, 2014

Sanders, Roger W., Kurt P. Wise, Joseph W. Francis, and Todd Charles Wood. "Toward 
a Practical Theology of Peer Review." Answers Research Journal 1 (2008): 6575.

Sanford, J. C. Genetic Entropy and the Mystery of the Genome. Hampden, MA: Elim Publishers, 2005.

Sarfati, Johnathan. Refuting Evolution. Green Forest, AR: Master Books, 1990.

Taylor, Ian T. In the Minds of Men: Darwin and the New World Order, $3^{\text {rd }}$ ed. Toronto: TFE Publishing, 1994.

Weeks, Noel. "The Hermeneutical Problem of Genesis 1-11." Themelios 4:1 (September, 1978): 12-19.

Whitcomb, John C. and Henry M. Morris, The Genesis Record: The Biblical Record and Its Scientific Implications. 1961. Reprint, Phillipsburg, NJ: Presbyterian and Reformed Publishing, 1995.

Woodmorappe, John. Noah's Ark: A Feasibility Study. El Cajon, CA: Institute For Creation Research, 1996.

Secondary Sources

Biblia Hebraica Stuttgartensia, eds. K. Ellinger and W. Rudolph. Stuttgart:

Württembergische Bibelanstalt Stuttgart, 1977 [1967].

Biblia Sacra: Iuxta Vulgatam Versionem. eds. B. Fischer, I. Gribomont, H.F.D. Sparks and W. Thiele. Stuttgart: Deutsche Bibelgesellschaft, 1994 [1969].

Novum Testamentum Graece, ed. K. Aland, M. Black, C. M. Martini, B. M. Metzger and A. Wikgren, $27^{\text {th }}$ ed. Stuttgart: Deutsche Bibelgesellschaft, 1993 [1898] [ = 'Nestle-Aland']. 
Septuaginta: Id est Vetus Testamentum graece iuxta LXX interpretes. ed. Alfred Rahlfs.

$8^{\text {th }}$ ed. 2 vols. Stuttgart: Württembergische Bibelanstalt Stuttgart, 1979 [1935].

The Holy Bible, Containing the Old and New Testaments with the

Apocrypha/Deuterocanonical Books: New Revised Standard Version. New York:

Oxford University Press, 1994.

The Holy Bible, Containing the Old and New Testaments: The Authorized Version.

Cambridge: Cambridge University Press, 1993 [1611].

The Scofield Study Bible, Containing the Old and New Testaments: The Authorized

Version. Edited by C. I. Scofield. New York: Oxford University Press, 1917. Reprint, 1996.

Aaron, David H. Biblical Ambiguities: Metaphor, Semantics, and Divine Imagery.

Boston: Brill Academic Publishers, 2002.

Alexander, Edward P. and Mary Alexander. Museums in Motion: An Introduction to the History of Museums, 2d ed. New York: Alta Mira Press, 2008.

Almond, Gabriel A., R. Scott Appleby and Emanuel Sivan. Strong Religion: The Rise of Fundamentalisms Around the World. Chicago: The University of Chicago Press, 2003.

Alpers, Svetlana. “The Museum as a Way of Seeing." In Museum Frictions: Public Cultures/Global Transformations, eds. Ivan Karp, Lynn Szwaja and Tomás Ybarra-Frausto, 25-32. Durham, NC: Duke University Press, 2006.

Alter, Robert. The Art of Biblical Narrative. New York: Basic Books, 1981. . Genesis: Translation and Commentary. New York: W. W. Norton \& Co., 1996. 
. The Five Books of Moses: A Translation with Commentary. New York:

W. W. Norton \& Co., 2004.

Ambrose, Timothy and Crispin Paine. Museum Basics. $3^{\text {rd }}$ ed. London: Routledge, 2012.

Ammerman, Nancy Tatom. Bible Believers: Fundamentalists in the Modern World. New Brunswick: Rutgers University Press, 1987.

Anderson, Benedict. Imagined Communities: Reflections on the Origin and Spread of Nationalism. Revised Edition. New York: Verso, 2003.

Anderson, Bernhard W. ed. Creation in the Old Testament. Vol. 6 Issues in Religion and Theology. Philadelphia: Fortress Press, 1984.

Anderson, Gail, ed. Reinventing the Museum: Historical and Contemporary Perspectives on the Paradigm Shift. New York: Alta Mira Press, 2004.

Antoun, Richard T. Understanding Fundamentalism: Christian, Islamic and Jewish Movements. 2d ed. Lanham, MD: Rowman and Littlefield Publishers, 2008.

Asma, Stephen T. Stuffed Animals and Pickled Heads: The Culture and Evolution of Natural History Museums. Oxford: Oxford University Press, 2001.

Arnold, Bill T. Genesis: The New Cambridge Bible Commentary. Cambridge: Cambridge University Press, 2009.

Atridge, Harold W. ed. The Religion and Science Debate: Why Does It Continue? New Haven: Yale University Press, 2009.

Bainton, Roland H. Here I Stand: A Life of Martin Luther. New York: Abingdon Press, 1950.

Balmer, Randall. They Kingdom Come: An Evangelical's Lament. New York: Basic Books, 2006. 
Bandstra, Barry L. Reading the Old Testament: An Introduction to the Hebrew Bible, 2d ed. Cincinnati, OH: Wadsworth Publishing Company, 1999.

Barr, James. The Semantics of Biblical Language. Oxford: Oxford University Press, 1961. . Fundamentalism. London: SCM Press, 1977.

Barton, Bernadette. Pray the Gay Away: The Extraordinary Lives of Bible Belt Gays. New York: New York University Press, 2012.

Basso, Keith H. Wisdom Sits in Places: Landscape and Language Among the Western Apache. Albuquerque: University of New Mexico Press, 1996.

Bauer, Walter. A Greek-English Lexicon of the New Testament and Other Early Christian Literature 2d ed. Chicago: The University of Chicago Press, 1979.

Berger, Peter L. The Sacred Canopy: Elements of a Sociological Theory of Religion. New York: Anchor Books, 1967.

Bielo, James S. Words Upon the Word: An Ethnography of Evangelical Group Bible Study. New York: New York University Press, 2009.

Bielo, James S. ed. The Social Life of Scriptures: Cross-Cultural Perspectives on Biblicism. New Brunswick, NJ: Rutgers University Press, 2009.

Bodnar, John. Remaking America: Public Memory, Commemoration, and Patriotism in the Twentieth Century. Princeton: Princeton University Press, 1992.

Boman, Thorleif. Hebrew Thought Compared with Greek. New York: W. W. Norton \& Co. 1970 .

Boone, Kathleen C. The Bible Tells Them So: The Discourse of Protestant Fundamentalism. Albany: State University of New York Press, 1989. 
Bourdieu, Pierre. Language and Symbolic Power. Edited by John B. Thompson.

Translated by Gino Raymond and Matthew Adamson. Cambridge, MA: Harvard University Press, 1991.

Bowler, Peter J. Monkey Trials and Gorilla Sermons: Evolution and Christianity from Darwin to Intelligent Design. Cambridge, MA: Harvard University Press, 2007. . Evolution: The History of An Idea. $25^{\text {th }}$ Anniv. Ed. Berkeley:

University of California Press, 2009.

Brooke, John Hedley. Science and Religion: Some Historical Perspectives. Cambridge: Cambridge University Press, 1991.

Brown, Francis, S. R. Driver and C. A. Briggs, Hebrew and English Lexicon of the Old Testament. Oxford: Clarendon Press, [1906] 1951.

Caird, G. B. The Language and Imagery of the Bible. London: Duckworth Publishers, 1980.

Cannell, Fenella. The Anthropology of Christianity. Durham, NC: Duke University Press, 2006.

Caputo, John D. Radical Hermeneutics: Repetition, Deconstruction, and the Hermeneutic Project. Bloomington, IN: Indiana University Press, 1987. Philosophy and Theology. Nashville: Abingdon Press, 2006.

Carpenter, Joel A. Revive Us Again: The Reawakening of American Fundamentalism. Oxford: Oxford University Press, 1997.

Carson, D. A. Exegetical Fallacies. Grand Rapids: Baker Book House, 1984.

Casey, Edward S. Imagining: A Phenomenological Study. Bloomington, IN: Indiana University Press, 1976. 
Castells, Manuel. The Rise of the Network Society. Vol. 1 of The Information Age: Economy, Society, and Culture. $2^{\text {nd }}$ ed. Malden, MA: Wiley-Blackwell, 2010. . The Power of Identity. Vol. 2 of The Information Age: Economy, Society, and Culture. $2^{\text {nd }}$ ed. Malden, MA: Wiley-Blackwell, 2009. . End of Millenium. Vol. 3 of The Information Age: Economy, Society, and Culture. $2^{\text {nd }}$ ed. Malden, MA: Wiley-Blackwell, 2010.

Charlesworth, M. J. The Problem of Religious Language. Englewood Cliffs, NJ: Prentice Hall, 1974.

Christakis, Nicholas A. and James H. Fowler. Connected: The Surprising Power of Our Social Networks and How They Shape Our Lives. New York: Little Brown and Co., 2009.

Coleman, Simon and Leslie Carlin eds. The Cultures of Creationism: Anti-Evolutionism in English-Speaking Countries. Burlington, VT: Ashgate Publishing, 2004.

Crapanzano, Vincent. Serving the Word: Literalism in America from the Pulpit to the Bench. New York: The New Press, 2000.

Crystal, David. Linguistics, Language and Religion. New York: Hawthorn Books, 1965. Dickinson, Greg, Carole Blair and Brian L. Ott eds. Places of Public Memory: The Rhetoric of Museums and Memorials. Tuscaloosa, AL: The University of Alabama Press, 2010.

Dreyfus, Hubert L. Being-in-the-World: A Commentary on Heidegger's Being and Time, Division I. Cambridge, MA: The MIT Press, 1991.

Duranti, Alessandro and Charles Goodwin eds. Rethinking Context: Language as an Interactive Phenomenon. Cambridge: Cambridge University Press, 1992. 
Duranti, Alessandro ed. Linguistic Anthropology: A Reader. Oxford: Blackwell Publishing, 2001.

Eberle, Gary. Dangerous Words: Talking About God in an Age of Fundamentalism. Boston: Trumpeter, 2007.

Eliade, Mircea. The Sacred and the Profane: The Nature of Religion. San Diego: Harcourt Brace Jovanovich, 1957.

Engle, P. E. ed. Baker's Wedding Handbook. Grand Rapids: Baker Books, 1994.

Enns, Peter. Inspiration and Incarnation: Evangelicals and the Problem of the Old Testament. Grand Rapids: Baker Academic, 2005. . The Evolution of Adam: What the Bible Does and Doesn't Say About Human Origins. Grand Rapids, MI: Brazos Press, 2012.

Fairclough, Norman. Language and Power. London: Longman, 1989. . Discourse and Social Change. Cambridge: Polity Press, 1992.

Falwell, Jerry ed. The Fundamentalist Phenomenon: The Resurgence of Conservative Christianity. New York: Doubleday, 1981.

Fischer, David Hackett. Historians' Fallacies: Toward a Logic of Historic Thought. New York: Harper Collins, 1970.

Foucault, Michel. The Foucault Reader. Edited by Paul Rabinow. New York: Pantheon Books, 1984. . Aesthetics, Method, and Epistemology. Edited by James D. Faubion and Translated by Robert Hurley and others. New York: The New Press, 1998. . The Politics of Truth. Translated by Sylvère Lotringer. Los Angeles:

Semiotext (e), 2007. 
Freedberg, David. The Power of Images: Studies in the History and Theory of Response. Chicago: The University of Chicago press, 1989.

Fretheim, Terence, E. "The Book of Genesis: Introduction, Commentary, and Reflections." Vol. 1 of The New Interpreter's Bible: A Commentary in Twelve Volumes. Nashville: Abingdon Press, 1994.

Gadamer, Hans-Georg. Heidegger's Ways. Translated by John W. Stanley. Albany, NY: State University of New York Press, 1994.

_. Philosophical Hermeneutics. Translated and edited by David E. Linge. Berkeley: University of California Press, 1976.

_. Truth and Method. Translated and edited by Joel Weinsheimer and Donald G. Marshall. $2^{\text {nd }}$ Rev. ed. 1989. Reprint, New York: Continuum, 2006. Gardner, John and John Maier. Gilgamesh: Translated from the Sin-Leqi-Unninnĩ version. New York: Vintage Books, 1984.

Gell-Mann, Murray. The Quark and the Jaguar: Adventures in the Simple and the Complex. New York: W. H. Freeman and Co., 1994.

Giberson, Karl W. Saving Darwin: How to be a Christian and Believe in Evolution. New York: HarperCollins, 2008.

Giberson, Karl W. and Mariano Artigas. Oracles of Science: Celebrity Scientists versus God and Religion. Oxford: Oxford University Press, 2001.

Giberson, Karl W. and Francis S. Collins. The Language of Science and Faith. Downers Grove, IL: Intervarsity Press, 2011.

Gladwell, Malcolm. The Tipping Point: How Little Things Can Make a Big Difference. New York: Back Bay Books, 2000. 
Glover, Gordon J. Beyond the Firmament: Understanding Science and the Theology of Creation. Chesapeake, VA: Water Tree Press, 2007.

Goodman, Lenn E. Creation and Evolution. London: Routledge, 2010.

Goodman, Nelson. Ways of Worldmaking. Indianapolis: Hackett Publishing, 1978.

Gottwald, Norman K. The Hebrew Bible: A Socio-Literary Introduction. Philadelphia: Fortress Press, 1985.

Gregory, Brad S. The Unintended Reformation: How a Religious Revolution Secularized Society. Cambridge, MA: The Belknap Press, 2012.

Gunn, Angus M. Intelligent Design and Fundamentalist Opposition to Evolution. Jefferson, North Carolina: McFarland \& Co., 2004.

Harding, Susan Friend. "Imagining the Last Days: The Politics of Apocalyptic Language." In Accounting for Fundamentalisms: The Dynamic Character of Movements, edited by Martin Marty and R. Scott Appleby. Chicago: The University of Chicago Press, 1994.

. The Book of Jerry Falwell: Fundamentalist Language and Politics. Princeton: Princeton University Press, 2000.

Hauser, Alan J. and Duane F. Watson eds. A History of Biblical Interpretation: The Ancient Period. Vol. 1, Grand Rapids: Eerdmans, 2003.

Hauser, Alan J. and Duane F. Watson eds. A History of Biblical Interpretation: The Medieval Through the Reformation Periods. Vol. 2, Grand Rapids: Eerdmans, 2009.

Hawkins, John A. and Murray Gell-Mann. The Evolution of Human Languages. Santa Fe, NM: Addison-Wesley Publishing, 1992. 
Heidegger, Martin. Being and Time. Translated by Joan Stambaugh. Albany: State University of New York Press, 2010.

_. The Question Concerning Technology: And Other Essays. Translated by William Lovitt. New York: Garland Publishing, 1977.

Heidel, Alexander. The Babylonian Genesis: The Story of Creation. $2^{\text {nd }}$ ed. Chicago: The University of Chicago Press, 1942.

Hein, Hilde S. The Museum in Transition: A Philosophical Perspective. Washington DC: Smithsonian Books, 2000.

Hiley, David R., James F. Bohman and Richard Shusterman eds. The Interpretive Turn: Philosophy, Science, Culture. Ithaca: Cornell, 1991.

Hirsch, E. D. Jr. Validity in Interpretation. New Haven: Yale University Press, 1967.

Holland, Dorothy and Naomi Quinn eds. Cultural Models in Language and Thought.

New York: Cambridge University Press, 1987.

Irwin-Zarecka, Iwona. Frames of Remembrance: The Dynamics of Collective Memory.

New Brunswick: Transaction Publishers, 2008.

Isaak, Mark. The Counter-Creation Handbook. Berkeley: University of California Press, 2007.

Jaki, Stanley L. Science and Creation: From Eternal Cycles to an Oscillating Universe. New York: Science History Publications, 1974.

_ God and the Cosmologists. Washington DC: Regnery Gateway, 1989. . Cosmos in Transition: Studies in the History of Cosmology. Tucson, AZ:

Pachart Publishing House, 1990. 
_Genesis 1 Through the Ages. $2^{\text {nd }}$ Rev. ed. Edinburgh: Scottish Academic Press, 1998.

_. Means to Method: A Treatise on Truth. Grand Rapids: William B.

Eerdman’s Publishing, 1999.

Johnson, Neil. Simply Complexity: A Clear Guide to Complexity Theory. Oxford:

Oneworld Publications, 2007.

Johnstone, Barbara. Qualitative Methods in Sociolinguistics. New York: Oxford University Press, 2000.

Juergensmeyer, Mark. Terror in the Mind of God: The Global Rise of Religious Violence. Berkeley: University of California Press, 2000. . The New Cold War: Religious Nationalism Confronts the Secular State. Berkeley: University of California Press, 1993.

Kauffman, Stuart. At Home in the Universe: The Search for the Laws of SelfOrganization and Complexity. Oxford: Oxford University Press, 1995.

Keel, Othmar. The Symbolism of the Biblical World: Ancient Near Eastern Iconography and the Book of Psalms. Translated by Timothy J. Hallett. New York: The Seabury Press, 1978.

Klein, Richard G. The Human Career: Human Biological and Cultural Origins. $3^{\text {rd }}$ ed. Chicago: The University of Chicago Press, 2009.

Knight, Douglas A. and Amy-Jill Levine. The Meaning of the Bible: What the Jewish Scriptures and Christian Old Testament Can Teach Us. New York: Harper One, 2011.

Kuhn, Thomas S. The Structure of Scientific Revolutions. Vol. II, 2d ed. Chicago: The 
University of Chicago Press, 1970.

Küng, Hans. The Beginning of All Things: Science and Religion. Grand Rapids: William B. Eerdmans Publishing Company, 2005.

Lakoff, George and Mark Johnson. Metaphors We Live By. Chicago: The University of Chicago Press, 1980.

Lamoureux, Denis O. Evolutionary Creation: A Christian Approach to Evolution. Eugene, Oregon: Wipf and Stock Publishers, 2007.

Larson, Edward J. Summer of the Gods: The Scopes Trial and America's Continuing Debate over Science and Religion. Cambridge, MA: Harvard University Press, 1997.

Lepore, Jill. The Whites of Their Eyes: The Tea Party's Revolution and the Battle over American History. Princeton: Princeton University press, 2010.

Levering, Miriam ed. Rethinking Scripture: Essays from a Comparative Perspective. Albany, NY: State University of New York Press, 1989.

Lindsell, Harold. The Battle for the Bible. Grand Rapids: Zondervan, 1976.

Long, David E. Evolution and Religion in American Education: An Ethnography. New York: Springer, 2011.

MacDonald, Nathan, Mark W. Elliott and Grant Macaskill eds. Genesis and Christian Theology. Grand Rapids: Eerdmans, 2012

MacDonald, Sharon ed. A Companion to Museum Studies. Oxford: Blackwell Publishing, 2011.

Machen, J. Gresham. Christianity and Liberalism. Grand Rapids: William B. Eerdman's Publishing, 1923. 
Malley, Brian. How the Bible Works: An Anthropological Study of Evangelical Biblicism. Walnut Creek, CA: Alta Mira Press, 2004.

Maltby, Paul. Christian Fundamentalism and the Culture of Disenchantment.

Charlottesville, VA: University of Virginia Press, 2013.

Marsden, George M. ed. Evangelicalism and Modern America. Grand Rapids: William B. Eerdman's Publishing Company, 1984. . Fundamentalism and American Culture. Oxford: Oxford University Press, 2006.

Marshall, I. Howard ed. New Testament Interpretation: Essays on Principles and Methods, Eugene, OR: Wipf and Stock Publishers, 2006.

Marty, Martin and R. Scott Appleby, eds. Fundamentalisms Observed. Chicago: University of Chicago Press, 1991. _. Fundamentalisms Comprehended. Chicago: The University of Chicago Press, 1995.

. Fundamentalisms and the State: Remaking Polities, Economies and Militance. Chicago: The University of Chicago Press, 1996.

. Fundamentalisms and Society: Reclaiming the Sciences, the Family and Education. Chicago: The University of Chicago Press, 1997. . Accounting for Fundamentalisms: The dynamic Character of Movements.

Chicago: The University of Chicago Press, 2004.

Marty, Martin E. and R. Scott Appleby. The Glory and the Power: The Fundamentalist Challenge to the Modern World. Boston: Beacon Press, 1992.

McCalla, Arthur. The Creationist Debate: The Encounter Between the Bible and the 
Historical Mind. New York: Continuum, 2006.

McCauley, Robert N. Why Religion is Natural and Science is Not. Oxford: Oxford University Press, 2011.

McGrath, Alister and Joanna Collicutt McGrath. The Dawkins Delusion: Atheist Fundamentalism and the Denial of the Divine. Downers Grove, IL: Inter Varsity Press, 2007.

Merrick, J., Stephen M. Garret. eds. Five Views on Biblical Inerrancy. Grand Rapids, MI: Zondervan, 2013.

Miller, John H. and Scott E Page eds. Complex Adaptive Systems: An Introduction to Computational Models of Social Life. Princeton: Princeton University Press, 2007.

Miller, Keith B. ed. Perspectives on an Evolving Creation. Grand Rapids: Eerdmans, 2003.

Miller, Kenneth R. Only a Theory: Evolution and the Battle for America's Soul. New York: Viking, 2008.

Montgomery, David R. The Rocks Don't Lie: A Geologist Investigates Noah's Flood. New York: W. W. Norton \& Co., 2012.

Moore, James. "The Creationist Cosmos of Protestant Fundamentalism.” In Fundamentalisms and Society: Reclaiming the sciences, the Family and Education, edited by Martin Marty and R. Scott Appleby. Chicago: The University of Chicago Press, 1993.

Moran, Jeffrey P. American Genesis: The Evolution Controversies from Scopes to Creation Science. Oxford: Oxford University Press, 2012. 
Mueller-Vollmer ed. The Hermeneutics Reader: Texts of the German Tradition from the Enlightenment to the Present. New York: Continuum Publishing, 1985.

Newman, Caroline ed. Official Guide to the Smithsonian: National Museum of Natural History. rev. ed. Washington DC: Smithsonian Books, 2008.

Nielsen, Neils C. Fundamentalism, Mythos, and World Religions. Albany: State University of New York Press, 1993.

Noll, Mark. The Scandal of the Evangelical Mind. Grand Rapids: William B. Eerdmans Publishing Co., 1994. . The New Shape of World Christianity: How American Experience Reflects Global Faith. Downers Grove: IL: Intervarsity Press, 2009.

Numbers, Ronald L. The Creationists: The Evolution of Scientific Creationism. Berkeley: University of California Press, 1992.

Nussbaum, Martha C. The New Religious Intolerance: Overcoming the Politics of Fear in An Anxious Age. Cambridge, MA: The Belknap Press, 2012.

Olick, Jeffrey K., Vered Vinitzky-Seroussi and Daniel Levy. The Collective Memory Reader. Oxford: Oxford University Press, 2011.

Omoniyi, Tope \& Joshua A. Fishmann eds., Explorations in the Sociology of Language and Religion. Philadelphia: John Benjamins Publishing Company, 2006.

Osborne, Grant R. The Hermeneutical Spiral: A Comprehensive Guide to Biblical Interpretation. Downers Grove, Illinois: Intervarsity Press, 1991.

Peirce, Charles S. Selected Writings: Values in a Universe of Chance. Edited by Philip P. Wiener. New York: Dover Publications, 1958.

Pierce, Charles P. Idiot America: How Stupidity Became a Virtue in the Land of the Free. 
New York: Anchor Books, 2010.

Pierce, John R. An Introduction to Information Theory: Symbols, Signals and Noise. New York: Dover Publications, 1961.

Pigliucci, Massimo and Maarten Boudry, eds. Philosophy of Pseudoscience: Reconsidering the Demarcation Problem. Chicago: The University of Chicago Press, 2013.

Pinker Steven. The Stuff of Thought: Language as a Window Into Human Nature. New York: Viking, 2007. . The Better Angels of Our Nature: Why Violence Has Declined. New York: Viking, 2011.

Plantinga, Alvin and Nicholas Wolsterstorff eds. Faith and Rationality: Reason and Belief in God. Notre Dame: University of Notre Dame Press, 1983.

Plate, S. Brent ed. Religion, Art and Visual Culture: A Cross Cultural Reader. New York: Palgrave, 2002.

Polanyi, Michael. Personal Knowledge: Towards a Post-Critical Philosophy. Chicago: The University of Chicago Press, 1958.

Polkinghorne, John. Testing Scripture: A Scientist Explores the Bible. Grand Rapids, MI: Brazos Press, 2010.

Porter, Stanley E. and Jason C. Robinson. Hermeneutics: An Introduction to Interpretive Theory. Grand Rapids: Eerdmans, 2011.

Prezioski, Donald and Claire Farago, eds. Grasping the World: The Idea of the Museum. Burlington, VT: Ashgate Publishing, 2004.

Prickett, Stephen. Origins of Narrative: The Romantic Appropriation of the Bible. 
Cambridge: Cambridge University Press, 1996. . Narrative, Religion and Science: Fundamentalism versus Irony, 17001999. Cambridge: Cambridge University Press, 2006.

Pritchard, James. B. ed. The Ancient Near East: An Anthology of Texts and Pictures. Vol. 1. Princeton: Princeton University Press, 1958. . The Ancient Near East: An Anthology of Texts and Pictures. Vol. 2. Princeton: Princeton University Press, 1975.

Pütz, Martin and René Dirven. The Construal of Space in Language and Thought. Cognitive Linguistics Research 8. Berlin/New York: Mouton de Gruyter, 1996. Radosh, Daniel. Rapture Ready: Adventures in the Parallel Universe of Christian Pop Culture. New York: Scribner, 2008.

Ramm, Bernard. The Christian View if Science and Scripture (Grand Rapids: William B. Eerdmans Publishing Co., 1954. Protestant Biblical Interpretation. Third Revised Edition. Grand Rapids: Baker, 1970.

Rau, Gerald. Mapping the Origins Debate: Six Models of the Beginning of Everything. Downers Grove, IL: Inter Varsity Press, 2012.

Ricoeur, Paul. Essays on Biblical Interpretation. Edited by Lewis S. Mudge. Philadelphia: Fortress Press, 1979. . Figuring the Sacred: Religion, Narrative and Imagination. Translated by David Pellauer. Minneapolis: Fortress Press, 1995.

Rosenhouse, Jason. Among the Creationists: Dispatches from the Anti-Evolution Front Line. Oxford: Oxford University Press, 2012. 
Roy, Olivier. Globalized Islam: The Search for a New Ummah. New York: Columbia University Press, 2004. . Holy Ignorance: When Religion and Culture Part Ways. Translated by

Ros Schwartz. New York: Columbia University Press, 2010.

Ruse, Michael. The Evolution-Creation Struggle. Cambridge: Harvard University Press, 2005.

Samarin, William J. ed. Language in Religious Practice. Rowley, MS: Newbury House, 1976.

Sarfati, Jonathan. Refuting Compromise. Green Forest, Arizona: Master Books, 2004. . Refuting Evolution. Green Forest, AR: Master Books, 1999.

Schmidt, Lawrence K. Understanding Hermeneutics. Stocksfield Hall, UK, 2006.

Scott, Eugenie C. Evolution vs. Creation: An Introduction. Berkeley: University of California Press, 2009.

Sedley, David. Creationism and Its Critics in Antiquity. Berkeley: University of California Press, 2007.

Seely, Paul H. Inerrant Wisdom: Science and Inerrancy in Biblical Perspective. Portland: Evangelical Reform Inc., 1989.

Semin, Gün R. and Kenneth J. Gergen eds. Everyday Understanding: Social and Scientific Implications. London: Sage Publications, 1990.

Shanks, Niall. God, the Devil, and Darwin: A Critique of Intelligent Design Theory. Oxford: Oxford University Press, 2004.

Shepherd, Gregory J., Jeffrey St. John and Ted Striphas eds. Communication as Perspectives on Theory, Thousand Oaks, CA: Sage Publications, 2006. 
Shermer, Michael. Why People Believe Weird Things: Pseudoscience, Superstition, and Other Confusions of Our Time. New York: St. Martin's Griffin, 2002.

Silverstein, Michael and Greg Urban eds. Natural Histories of Discourse. Chicago: The University of Chicago Press, 1996.

Singham, Mano. God vs. Evolution: The War Between Evolution and Creationism in the Classroom. New York: Rowman \& Littlefield Publishers, 2009.

Smith, Christian. The Bible Made Impossible: Why Biblicism Is Not a Truly Evangelical Reading of Scripture. Grand Rapids, MI: Brazos Press, 2011. American Evangelicals: Embattled and Thriving. Chicago: The University of Chicago Press, 1998.

Soulen, Richard N. Handbook of Biblical Criticism, 2d ed. Atlanta: John Knox Press, 1981.

Southgate, Christopher. The Groaning of Creation: God, Evolution, and the Problem of Evil. Louisville: Westminster John Knox Press, 2008.

Sparks, Kenton L. God's Word in Human Words: An Evangelical Appropriation of Critical Biblical Scholarship. Grand Rapids: Baker Academic, 2008. Ancient Texts for the Study of the Hebrew Bible: A Guide to the Background Literature. Peabody, MA: Hendrickson Publishers, 2005. Speiser, E. A. Genesis: A New Translation with Introduction and Commentary. New York: Doubleday \& Co., 1986.

Stadelmann, Luis I. The Hebrew Conception of the World: A Philological and Literary Study. Rome: Pontifical Biblical Institute, 1970.

Stanley, Christopher D. The Hebrew Bible: A Comparative Approach. Minneapolis, 
Fortress Press, 2010.

Steiner, George. After Babel: Aspects of Language and Translation. $3^{\text {rd }}$ ed. Oxford:

Oxford University Press, 1998.

Stephens, Randall J. and Karl W. Giberson. The Anointed: Evangelical Truth in a Secular Age. Cambridge, MA: Harvard University Press, 2011.

Stiver, Dan R. The Philosophy of Religious Language: Sign, Symbol and Story. Oxford: Blackwell Publishing, 1996.

Stricklin, David. A Genealogy of Dissent: Southern Baptist Protest in the Twentieth Century. Lexington, KY: The University Press of Kentucky, 1999.

Strozier, Charles B., David M. Terman and James W. Jones. The Fundamentalist Mindset: Psychological Perspectives on Religion, Violence, and History. Oxford: Oxford University Press, 2010.

Tannen, Deborah. ed. Framing in Discourse. New York: Oxford University Press, 1993. Taylor, Charles. A Secular Age. Cambridge: Harvard University Press, 2007.

Taylor, Mark C. After God. Chicago: The University Of Chicago Press, 2007. . Confidence Games: Money and Markets in a World Without Redemption. Chicago: The University of Chicago Press, 2004. . The Moment of Complexity: Emerging Network Culture. Chicago: The University of Chicago Press, 2001.

Terry, Milton S. Biblical Hermeneutics: A Treatise on the Interpretation of the Old and New Testament. New York: Hunt and Eason, 1890. Reprint, Eugene, Oregon: Wipf and Stock Publishers, 1999.

Thiselton, Anthony C. Hermeneutics: An Introduction. Grand Rapids: William B. 
Eerdmans Publishing Company, 2009.

. The Two Horizons: New Testament Hermeneutics and Philosophical

Description. Grand Rapids: William B. Eerdmans Publishing Company, 1980.

Thomas, Linda \& Shan Wareing, eds., Language, Society and Power. London:

Routledge, 1999.

Toumey, Christopher P. Conjuring Science: Scientific Symbols and Cultural Meanings in American Life. New Brunswick, NJ: Rutgers University Press, 1996. . God's Own Scientists: Creationists in a Secular World. New

Brunswick, NJ: Rutgers University Press, 1994.

Torrey, R. A. and A. C. Dixon et. al. eds. The Fundamentals: A Testimony to the Truth. Vols. I and II. Grand Rapids: Baker Books, 1917 (Reprint 2008).

Van Berkel, Klaas and Arjo Vanderjagt eds. The Book of Nature in Early Modern and Modern History. Leuven, Belgium: Peeters, 2006.

Van Buren, Paul M. The Edges of Language: An Essay in the Logic of a Religion. New York: Macmillan, 1972.

Van Dijk, Teun A. Ideology: A Multidisciplinary Approach. London: Sage Publications, 1998.

Van Noppen, Jean-Pierre ed. Theolinguistics. Brussels: University of Brussels, 1981. . ed. Metaphor and Religion: Theolinguistics II. Brussels: University of Brussels, 1983.

_. "Interpretation Fallacies" in The Science and Theology of Information.

Edited by C. Wasserman, R. Kirby and B. Rordoff. Geneva: Labor, 1990.

Van Till, Howard J., Davis A. Young and Clarence Menninga. Science Held Hostage: 
What's Wrong with Creation Science and Evolutionism. Downers Grove, IL: InterVarsity Press, 1988.

Von Rad, Gerhard. Genesis. Revised Ed. Philadelphia: The Westminster Press, 1961.

Walton, John H. The Lost World of Genesis One: Ancient Cosmology and the Origins Debate. Downers Grove, Illinois: Intervarsity Press, 2009.

Wardhaugh, Ronald. An Introduction to Sociolinguistics. $5^{\text {th }}$ ed. Malden, MA: Blackwell Publishing, 2006.

Weil, Stephen E. Making Museums Matter. Washington DC: Smithsonian Books, 2002.

Wittgenstein, Ludwig. Philosophical Investigations. Translated by G. E. M. Anscombe. New York: Macmillan, 1953.

Worthen, Molly. Apostles of Reason: The Crisis of Authority in American Evangelicalism. Oxford: Oxford University Press, 2014.

Wright. M. R. Cosmology in Antiquity. London: Routledge, 1995.

Wuthnow, Robert. America and the Challenges of Religious Diversity. Princeton: Princeton University Press, 2005. American Mythos: Why Our Best Efforts to be a Better Nation Fall Short. Princeton: Princeton University Press, 2006.

Young, Matt and Taner Edis. Why Intelligent Design Fails: A Scientiofic Critique of the New Creationism. New Brunswick: Rutgers University Press, 2006.

Zelizer, Barbie, ed. The Changing Faces of Journalism: Tabloidization, Technology and Truthiness. New York: Routledge, 2009. 
Articles

Aftab, Cheung, Kim, Thakkar, and Yeddanapudi. "Information Theory: Information theory and the Digital Age." 6.933 Final Paper as per Project History at Massachusetts Institute of Technology (Fall 2001): 1-27.

Alderman, George Allan III. "Dinosaur Adventure Land, or How Max Defeated the Creationist Swing Set." Reports of the National Center for Science Education. 31, no. 6 (November/December 2011): 1-5.

Arroyo, Leah. "Science on Faith at the Creation Museum." Museum News. American Association of Museums. (November/December 2007), under "Publications," http://www.aam-us.org/pubs/mn/scienceonfaith.cfm (accessed November 25, 2010).

Asma, Stephen T. "Risen Apes and Fallen Angels: The New Museology of Human Origins.” Curator 54:2 (April 2011): 141-63. . "Dinosaurs on the Ark: The Creation Museum." Chronicle of Higher Education 53:37 (May 2007): B10-13.

Barr, James. "Literality.” Faith and Philosophy 6:4 (October 1989): 412-28.

Bartkowski, John. "Beyond Biblical Literalism and Inerrancy: Conservative Protestants and the Hermeneutic Interpretation of Scripture.” Sociology of Religion 57 (1996): 259-72.

Blancke, Stefaan, Hans Henrik Hjermitsley, Johan Braeckman, and Peter Kjaergaard. “Creationism in Europe: Facts, Gaps, and Prospecst." Journal of the American Academy of Religion 81 (December 2013): 996-1028.

Blewitt, John. "The Eden Project: Making a Connection.” Museum and Society 2 (Nov 
2004): 175-189.

Branch, Glenn. "Understanding Creationism After Kitzmiller." BioScience 57 (March 2007):278-84.

Bryman, Alan. "The Disneyization of Society.” The Sociological Review 47 (1999):2547.

Butler, Ella. "God is in the Data: Epistemologies of Knowledge at the Creation Museum.” Ethnos 75:3 (September 2010): 229-51.

Carrier, Marc. "Muslim Creationism and the Curious Case of Harun Yahya: A Look at a High-profile Muslim Creationist and His Christian Friends in the U. S.” Skeptic Magazine 16:3 (2011): 32-37.

Casey, Valerie. "The Museum Effect: Gazing from Object to Performance in the Contemporary Cultural-History Museum." Paper delivered at Cultural Institutions and Digital Technology. Ecole du Louvre, Paris. 8-12 Spetember 2003.

Chang, Kenneth. "Paleontology and Creationism Meet but Don't Mesh." The New York Times June 30, 2009. http://www.nytimes.com/2009/06/30/science 130muse.html?pagewanted=all (accessed October 5, 2011).

Cho, Francisca and Richard King Squuier. "Religion as a Complex and Dynamic System.” Journal of the American Academy of Religion 81 (June, 2013): 357-98. Douthat, Ross. "Why Atheists Need Fundamentalists." The New York Times October 4, 2011. http://douthat.blogs.nytimes.com/2011/10/04/why-atheists-needfundamentalists/ (accessed October 5, 2011).

Duff, R. Joel. "Flood Geology’s Abominable Mystery." Perspectives on Science and Christian Faith 60 (September 2008): 166-77. 
Duncan, Julie. "Credibility, Profitability, and Irrefutability: Why Creationists are Building Museums." Reports of the National Center for Science Education. 29, no. 5 (September/October 2009): 17-20.

Eve, Raymond A. "Reflections on a Visit to the Creation Museum." Reports for the National Center for Science Education. 29, no. 5 (September/October 2009): 3133 http://ncse.com/rncse/29/5/reflections-visit-to-creation-museum (accessed November 17, 2010).

Fish, Stanley. "Postmodern Warfare: The Ignorance of our Warrior Intellectuals." Harper's Magazine. (July 2002):33-40. _ "Academic Cross-Dressing: How Intelligent Design gets its Arguments from the Left." Harper's (Dec. 2005): 70-73.

Gill, A. A. "Roll Over, Charles Darwin.” Vanity Fair 594 (Feb. 2010): 72-75.

Gill, Jerry H. "Wittgenstein and Religious Language.” Theology Today 21 (April 1964): $59-72$.

Gould, Stephen Jay. “Nonoverlapping Magisteria.” Natural History 106 (March 1997): 16-62.

Harding, Susan Friend. "Convicted by the Holy Spirit: The Rhetoric of Fundamental Baptist Conversion.” American Ethnologist 14(1) (1987) 167-181.

Hasel, G. F. "The Significance of Cosmology in Genesis 1 in Relation to Ancient Near Eastern Parallels.” Andrews University Seminary Studies 10 (1972) 1-20.

Hein, Hilde. "Institutional Blessing: The Museum as Canon-Maker." The Monist 76 (October 1993): 556-73.

Keane, Webb. "Religious Language." Annual Review of Anthropology 26 (1997) 47-71.

Knell, Simon J. "The Shape of Things to Come: Museums in the Technological 
Landscape." Museum and Society 1 (Nov 2003): 132-46.

Lamoureux, Denis O. "Lessons from the Heavens: On Scripture, Science and Inerrancy." Perspectives on Science and Christian Faith 60 (2008) 4-15.

Launius, Roger D. “American Memory, Culture Wars, and the Challenge of Presenting Science and Technology in a National Museum.” The Public Historian 29:1 (Winter 2007): 13-30.

Long, David E. "Scientists at play in a field of the Lord." Cultural Studies of Science Education. (2010): 213-35.

Luhrman, Tanya M. “Metakinesis: How God Becomes Intimate in Contemporary U. S. Christianity." American Anthropologist 106:3 (September 2004): 518-28.

Lynch, John. "Prepare to Believe: The Creation Museum as Embodied Conversion Narrative." Rhetoric and Public Affairs 16 (2013): 1-28.

Mahmood, Saba. "Religious Reason and Secular Affect: An Incommensurable Divide?" Critical inquiry 35:4 (Summer 2009): 836-62.

Marty, Martin E. "Explaining the Rise of Fundamentalism.” Bulletin of the American Academy of Arts and Sciences 46 (Feb. 1993): 5-9.

Mathisen, Gerals S. and James A. Mathisen. "The New Fundamentalsim: A Sociorhetorical Approach to Understanding Theological Change.” Review of Religious Research 30 (September 1988): 18-32.

Miller, John D. Eugenie C. Scott and Shinji Okamoto "Public Acceptance of Evolution." Science 313 (2006) 765-66.

Olmstead, A. T. "History, Ancient World, and the Bible: Problems of Attitude and of Method." Journal of Near Eastern Studies 2 (January, 1943): 1-34. 
Phelps, Daniel. “The Anti-Museum: An Overview and Review of the Answers in Genesis Creation 'Museum.”' National Center for Science Education (October 17, 2008) http://ncse.com/creationism/general/anti-museum-overview-review-answersgenesis-creation-museum?gclid=COiU9aO19KQCFUbX5wodby9MhA (accessed November 21, 2010).

Rosenberg, Bruce A. “The Formulaic Quality of Spontaneous Sermons.” The Journal of American Folklore 83 (Jan. - Mar. 1970): 3-20.

Rothstein, Edward. "Adam and Eve in the Land of the Dinosaurs." The New York Times, May, 24 2007. http://www.nytimes.com/2007/05/24/arts/24crea.html? pagewanted=all (accessed October 5, 2010).

Scott, Eugenie C. "Antievolution and Creationism in the United States." Annual Review Of Anthropology. 26 (1997): 263-89.

Seely, Paul H. “The Three-Storied Universe.” Journal of the American Scientific Affiliation. 21 (1969) 18-22.

. "The First Four Days of Genesis in Concordist Theory and in Biblical Context." Journal of the American Scientific Affiliation 49 (June 1997): 85-95. Sepkoski, David. "Worldviews in Collision: Recent Literature on the Creation-Evolution Divide." Journal of the History of Biology 39 (2006): 607-35.

Sherzer, Joel. “A Discourse-Centered Approach to Language and Culture.” American Anthropologist 89:2 (June 1987): 295-309.

Swidler, Ann. "Culture in Action: Symbols and Strategies.” American Sociological Review 51:2 (April, 1986): 273-86.

Taylor, Mark C. "Refiguring Religion." Journal of the American Academy of Religion 
77:1 (March, 2009): 105-119.

Von Rad, Gerhard. Genesis. Rev. ed. Philadelphia: The Westminster Press, 1971.

Watkins, Steve. "Dragon Snakes and Fictitious Fruit: What Happens When Myths are Literalized." The Fourth R: An Advocate for Religious Literacy 26 (March-April 2013): 6-8.

Weil, Stephen E. "From Being about Something to Being for Somebody: The Ongoing Transformation of the American Museum.” Daedalus 128 (Summer, 1999): 22958.

Westermann, Claus. Genesis: A Practical Commentary. Translated by David E. Green. Grand Rapids, MI: Willaim B. Eerdmans Publishing, 1987.

Weston, William. “Creation vs. Evolution.” Kentucky Humanities (April, 2009): 9-13.

Wilken, Robert L. “The Church's Way of Speaking.” First Things (August/September 2005) 27-31.

Wright, J. Edward. "Biblical Versus Israelite Images of the Heavenly Realm.” Journal for the Study of the Old Testament 93 (2001): 59-75.

Zelizer, Barbie. "When Facts, Truth, and Reality Are God-Terms: On Journalism's Uneasy Place in Cultural Studies." Communication and Critical/Cultural Studies 1 (March 2004):110-19.

___ "Reading the Past Against the Grain: The Shape of Memory Studies." Critical Studies in Mass Communication 12 (June 1995): 214-39. 


\section{APPENDIX A}

\section{A NNARRATIVE OVERVIEW OF THE CREATION MUSEUM}

The following narrative provides an overview of the various components that comprise the Creation Museum (CM). Opened to the public in the spring of 2007, the CM is located in Petersburg, Kentucky, off Interstate 275 , about thirty minutes from Cincinnati, Ohio. As one approaches the museum from a two-lane road, a beige, stonewall forms a barrier between approaching cars and the grounds of the CM. Perched atop the wall at the main entrance are two stegosaur silhouettes - one on the left wall and one on the right. They are constructed of metal and are greenish in color. The only words appearing on the wall are the simple phrase "Creation Museum."

The grounds are meticulously manicured and tastefully landscaped. Pulling through the main gate, a winding one-way road leads to the parking area. On the right, are the beautiful botanical gardens and wooded hillside sloping gently into a scenic lake. Straight ahead is the CM building with large tinted glass windows covering the entire front side of the museum. The tan museum's walls are contemporary in design. One observation worth noting is that, except for the words "Creation Museum" on the outer walls, there is no feature that would hint that this is a Christian facility-e.g. crosses, cathedral-like architecture, or signs. Just before turning left into the parking lot, one can see a large bronze-colored dinosaur located in the middle of the plaza just before the 
main entrance to the building.

A security guard stands at the curb directing visitors to turn left into the parking lot. There are almost always a few church vans in the lot as well as one or two large tour buses. The buses park toward the side of the CM away from the main parking section. As one walks toward the entrance, the bronze dinosaur emerges. Depending on the time of year, one may spot temporary exhibits to the right of the plaza entrance. For example, during the month of December one such exhibit is "Christmas Town," a mock-up interpretation of ancient Bethlehem. For an additional fee, visitors can walk through the exhibit of animals and stand-in actors of this nativity village.

On a recent visit, I noticed that white dinosaur footprints were painted on the parking lot. The footprints form a path leading visitors to the entrance. One enters the main building through tinted glass doors that blend in with windows which forms a façade to the entry Portico. ${ }^{495}$ The Portico is lined with a paving stone floor that wraps around toward the ticketing booth. The bookstore's main entrance is located off of the Main Hall. After securing a ticket, the Portico continues on toward the Main Hall past the last stop, a photo opportunity in front of a Pterodactyl suspended from the ceiling. CM workers wear tan, safari-like vests as uniforms. The photo booth workers sometimes ask to take your picture while walking into the Main Hall. The photos can be purchased later for an additional fee.

A large Woolly Mammoth skeleton is usually on display in the Main Hall. During the Christmas season, the Mammoth is moved to make room for temporary decorations.

${ }^{495}$ I will capitalize words like "Portico" when these terms appear in CM publications as specifically named designations. Unless otherwise noted, the publication I am using for these locations is a Museum Map and Garden Map which is given to visitors, free of charge. I have added copies of these maps at the end of this article. 
This area is the central starting point for a number of different options. On the far left of the plaza is a serpentine rail that leads to the Stargazer's Planetarium. Located at the far right side of the Main Hall is Noah's Café, a full restaurant that has tables for dining in as well as an outside deck which overlooks the lake and botanical gardens.

From the Main Hall, the visitor may take any number of initial paths. The Stargazer's Planetarium, the Special Effects Theater, the Dragon Hall Bookstore and the Main Exhibit are all adjacent to this central area and there is no set order as to which locations one must visit. So I will begin with a description of the Main Exhibit. On the sides of the Main Hall, leading to the entrance of the Main Exhibit, are two sets of displays. On the left are two children playing next to a pool of water. But most startling is the animatronic dinosaur standing only several yards from a female child. The scene is made to present fully developed homo-sapiens as existing at the same time as Jurassic Period dinosaurs. The humans are portrayed with simple, unsophisticated clothing-i.e. a loosely fitting, primitive looking blouse and no shoes (see photo below). 


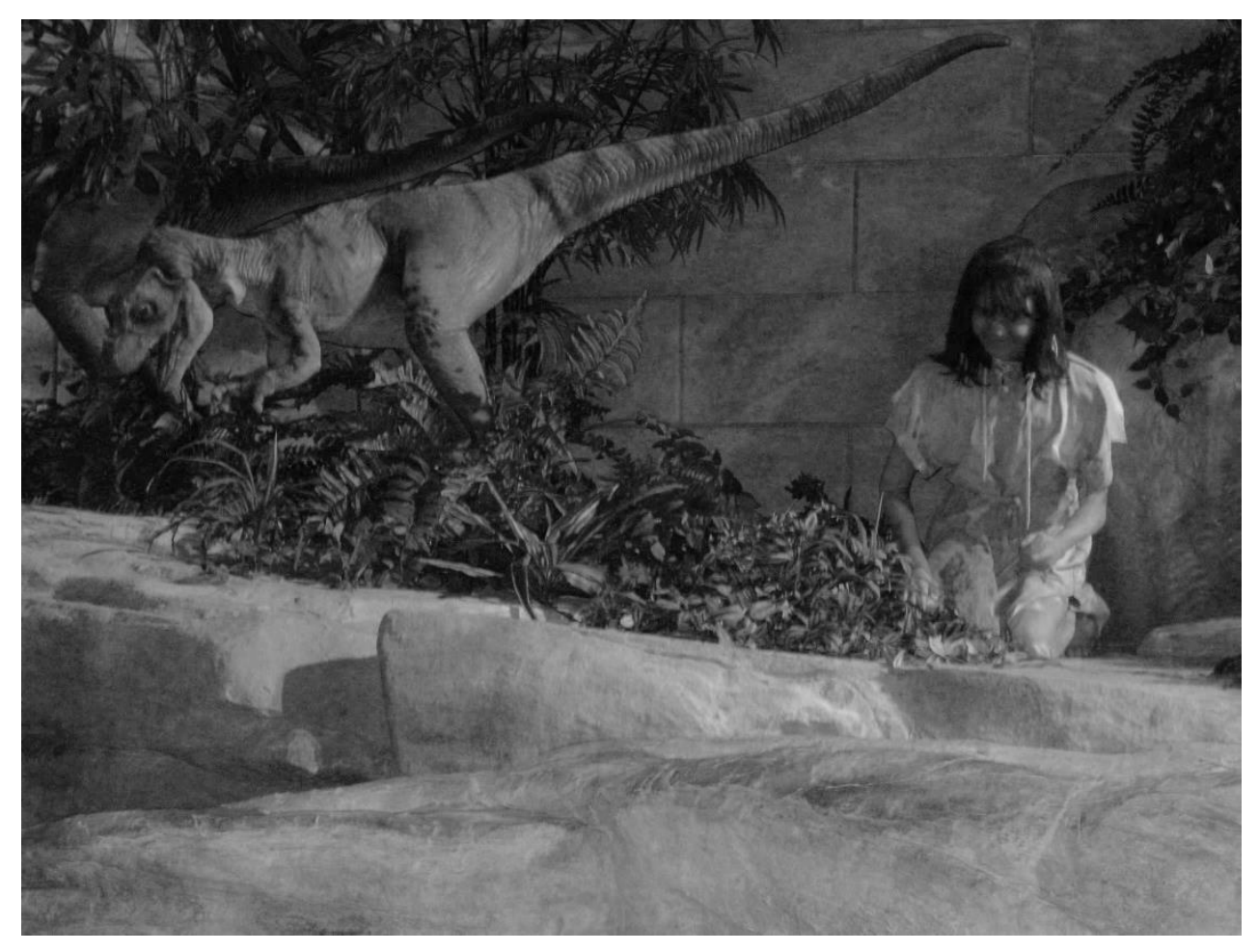

Photo 8.The animatronic Velociraptor next to a human child. (Photo: S. Watkins)

The right side of the Main Hall contains glass dioramas with a diversity of animals: varieties of colorful finches, poison dart frogs, and a chameleon. In each display, there are placards that make assertions about the falsities of evolution and the correctness of Young Earth Creationism (YEC). For example, one display reads: "Fossils the Biblical view-Views about fossils have come and gone. But fossils do not tell us where these creatures came from or how they died. Fortunately, we have another source of factual data - the first book of the Bible, Genesis." Thus, before one enters the Main Exhibits, the pre-suppositional groundwork is stated for defending a certain biblical interpretation and for attacking current scientific theory.

The pathway between dioramas leads the visitor to the Main Exhibit entrance. The following summary will narrate the visitor's walk from room to room; this offers a 
cursory explanation as there is an overwhelming amount of information in any given room. The titles for the rooms are taken from the map provided at the end of this document.

After showing one's ticket to an attendant, the visitor enters Slot Canyon and Ranger Station. The Ranger Station contains a video screen with an explanation that the Mount St. Helen eruption is proof that canyons and rock layers may be formed rapidly. The environment is designed to look and feel like a trip to the Grand Canyon. ${ }^{496}$

The next exhibit is the Dig Site. This display shows two mannequins as paleontologists digging up the fossil remains of a Utahraptor. This site informs the visitor that there are two fundamental ways in which to interpret fossil data - and by extension all empirical data. The first way is through human reason and this is equated with the methodology of mainstream science. The second way is from the revelation contained in the Bible. This is the beginning of a dichotomy that follows into almost every argument presented at the CM.

This basic argument is restated in the next room, Starting Points. This room is attractively decorated with hardwood floors and subtle lighting that creates a sophisticated art gallery feel. The dichotomy mentioned above is repeated here in placards stating that "to understand the universe, there are only two possible places to start: (a) the Word of the One Who has always been there and knows everything (the Creator God of the Bible) or (b) autonomous human reason (man's beliefs)." This room

\footnotetext{
${ }^{496}$ I have made the connection of the entryway with the Grand Canyon based on my visits to both places. The likeness of the Grand Canyon has also been made by other scholars. Daniel Phelps, "The AntiMuseum: An Overview and Review of the Answers in Genesis Creation 'Museum." National Center for Science Education Reports (October 17, 2008) http://ncse.com/creationism/general/anti-museumoverview-review-answers-genesis-creation-museum?gclid=COiU9aO19KQCFUbX5wodby9MhA (accessed November 21, 2010).
} 
shows numerous pictures of animals, fossils, and ecological settings with the dichotomy applied in each case. The argument becomes a refrain throughout the museum-i.e. We all look at the same evidence (any empirical aspects of the world), but different conclusions are drawn because of different starting points or presuppositions. This room does an impressive job in framing two, mutually exclusive epistemological premiseshuman reason (evolutionary science) and God's Word (the Bible). The premises are presented on large display boards (Photo 2) that offer two competing epistemological frameworks. These display boards are important objects for hermeneutic, linguistic, and information screening in my dissertation analysis.

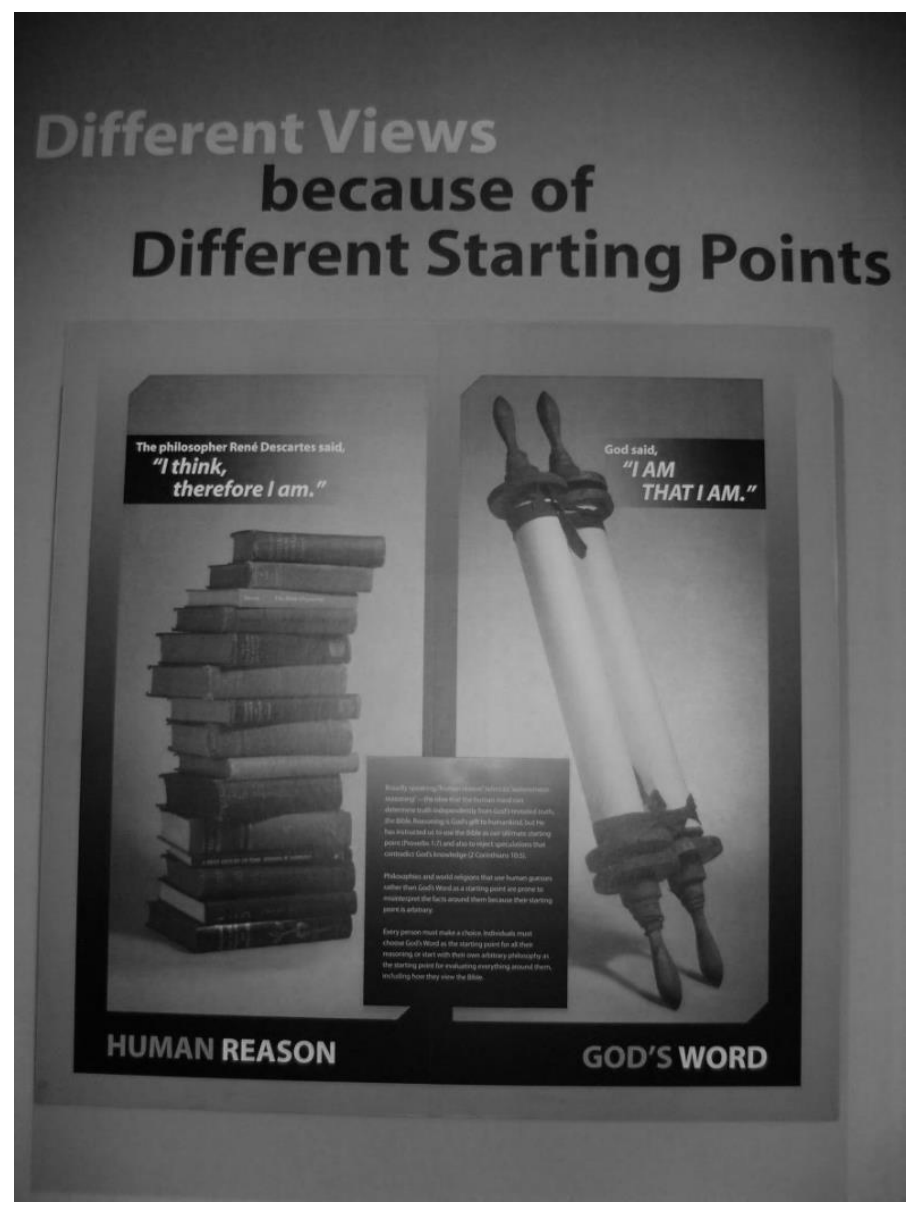

Photo 9. The display board pictured above is one example of the numerous presentations of two mutually exclusive epistemologies that are presented as Starting Points. (Photo: S. Watkins) 
The following two rooms are titled Biblical Authority and Biblical Relevance. As the argument proceeds, the establishment of the Bible as the inspired and inerrant Word of God becomes a major premise of the museum's argument. The Biblical Authority room contains mannequins of Moses, Isaiah, and David with the emphasis on their status as inspired prophets through whom God revealed the scriptures. Adjacent to this room, the visitor moves into a more polemic section titled Biblical Relevance. This room contains three main aspects: a mannequin of Martin Luther nailing his Ninety-Five Theses to the Wittenburg door, a replica of Gutenberg's press, and a wall containing a revisionist explanation of the Scopes Trial (including a looping video documentary). The Scopes Trial appears to be the pivotal point in Christian history as the next room implies that culture has fallen apart. The main theme in this room is summarized in a CM publication: "Throughout history, there have been movements to return to God's Word when it has been attacked. In the sixteenth century, Martin Luther began a movement called the Reformation, which called people back to the authority of the Word of God."497 Though the connection is not stated explicitly, the implication is that the current movement to return to God's Word is that of the CM in response to evolution — as hinted at in the Scopes display.

${ }^{497}$ Journey Through the Creation Museum (Green Forest, AZ: Master Books, 2008), 32. 


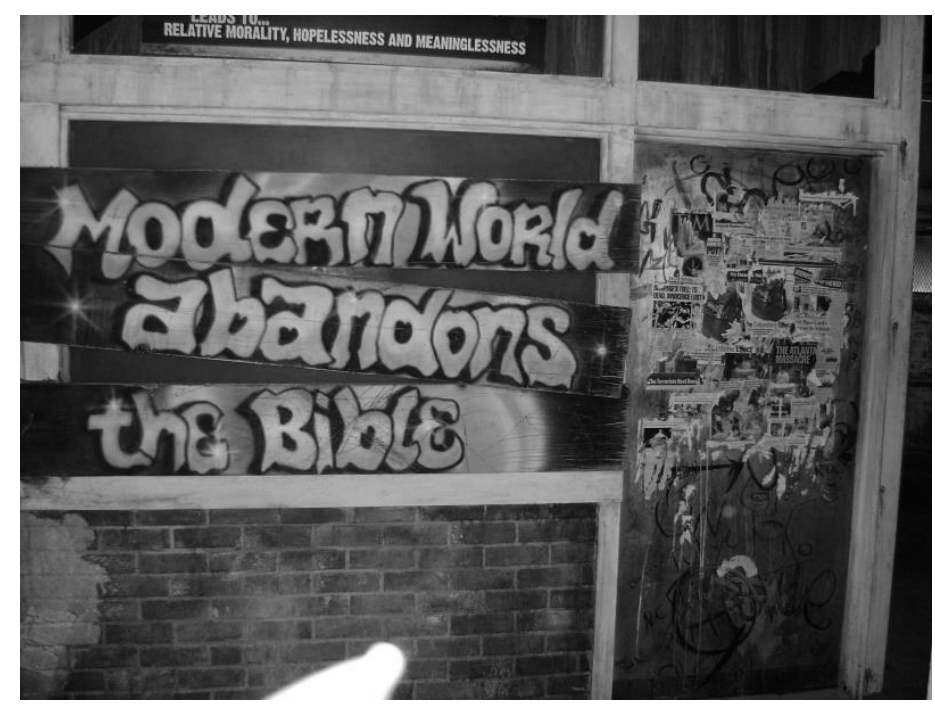

Photo 10. The entrance to Graffiti Alley. (Photo S. Watkins)

Leaving this room leads to a dark area made to look like an inner-city alley.

Fittingly titled Graffiti Alley, a negative impression is summoned with the hint written in graffiti-style spray paint_-"Modern World Abandons the Bible." The idea of the modern world collapsing into moral decay, crime, and tragedy is another repeated premise at the CM. Further, the cause of such societal decay is always related to an alleged devaluing of the Bible.

After passing through Graffiti Alley, the visitor enters a room titled Culture in Crisis. One display shows a traditional church building knocked down by a wrecking ball which is labeled "Millions of Years." There are four or five video screens which display looped sequences of various crises. One shows an adolescent boy rolling a joint and another presents a young lady contemplating abortion. A video presents a mainstream church congregation being lectured on Theistic Evolution. The congregants are shown to be bored as they yawn at the uninspiring sermon. Young, tuned-out teenagers play with Iphones as the minister drones on. This is an interesting part of the CM's presentation of the Church as part of the problems of the modern world and also as a victim of the 
modern world. Culture in Crisis is one of the darkest and most pejorative exhibits of the CM.

The visitor exits Culture in Crisis through a narrow Time Tunnel—a dark corridor lit only by hundreds of small, white diodes. The tunnel is designed to provide the visitor with the feeling of travelling back in time, "to the beginning of biblical history to find these important answers." 498 The answers to "these important questions" are the solutions to why culture is in such a crisis. Thus, a journey back through God's word to the beginning of creation is necessary. The Time Tunnel leads the visitor to the Six Days Theater.

This small theater shows a continuously looping video in which the YEC reading of Genesis 1 is retold and illustrated. The video maintains an upbeat and positive feel as it displays beautiful scenes of nature accompanied by a classical, uplifting musical score. My impression is that the solution to a Culture-in-Crisis comes only through a return to a proper (i.e. literal) reading of the first chapter of Genesis.

Following the Six Days Theater, the visitor enters another well-lit and friendly space called the Wonders Room. Similar in feel to the Starting Points room, the Wonders Room is positive and contains lively classical music in the background. Colorful display boards present a number of YEC inferences. The common emphases in these displays present various aspects of Thomas Aquinas' teleological argument for the existence of God. Summarily, the point is that complexity and order in the universe point to a supreme designer. The room contains fifteen videos that are synchronized to end and begin in order as the visitor moves from screen to screen. The goal of the Wonders Room "leaves viewers with the evidence of the only explanation that makes sense - there has to be a

\footnotetext{
${ }^{498}$ Ibid, 36.
} 
powerful Intelligence behind the universe." ${ }^{, 499}$

The Wonders Room subtly merges into the largest sequence of exhibits, the

Creation Walk. The Creation Walk comprises the largest portion of the museum.

Organized around the acrostic of Seven C's (Creation, Corruption, Catastrophe,

Confusion, Christ, Cross, and Consummation), this part of the exhibit is laid-out as a walking narrative of sorts. ${ }^{500}$ The Creation Walk covers the largest area of floor space in the entire building. The vast majority of space is devoted to the first four C's (Creation, Corruption, Catastrophe, and Confusion). The last three C's (Christ, Cross, and Consummation) are all compressed into one, fairly short video production called The Last Adam Theater. ${ }^{501}$ The first four C's is an audio-visual interpretation of the first eleven chapters of Genesis.

The first "C," Creation, begins in a literal Garden of Eden. A naked mannequin of Adam is seen kneeling under a tree as all different species of animals surround him. One striking observation (shown in Photo 4) is the portrayal of animals from all different continents side-by-side in the garden - including dinosaurs. A penguin appears in the same setting as warm climate animals such as a chimpanzee and a kangaroo. For theological reasons, all of the animals in the Creation section are said to be vegetariansincluding dinosaurs and modern carnivores. The claim is that animals only became

${ }^{499}$ Ibid, 39.

${ }^{500}$ The CM uses an apostrophe when referring to the plural "C's." Although this is an older convention, I will include the apostrophe in my writing for consistency.

${ }^{501}$ The fact that Christ, Cross, and Consummation (Consummation is an eschatological reference to the teleological goal of final Christian redemption and restoration) are conflated into one, fairly brief video presentation is revealing. I will analyze this preference for and emphasis on the pre-patriarchal narratives (Creation in Genesis 1-2, Corruption in Genesis 3, Catastrophe in Genesis 6-9, and Confusion in Genesis 11). I mention it here because the vast majority of the resources and floor space at the CM are focused on a very small portion of the actual Christian canon-amounting to about ten to fifteen chapters out of over eleven-hundred chapters in the Old and New Testaments (not including the Apocrypha-which the $\mathrm{CM}$ rejects as canonical). 
carnivores after the fall in Eden.

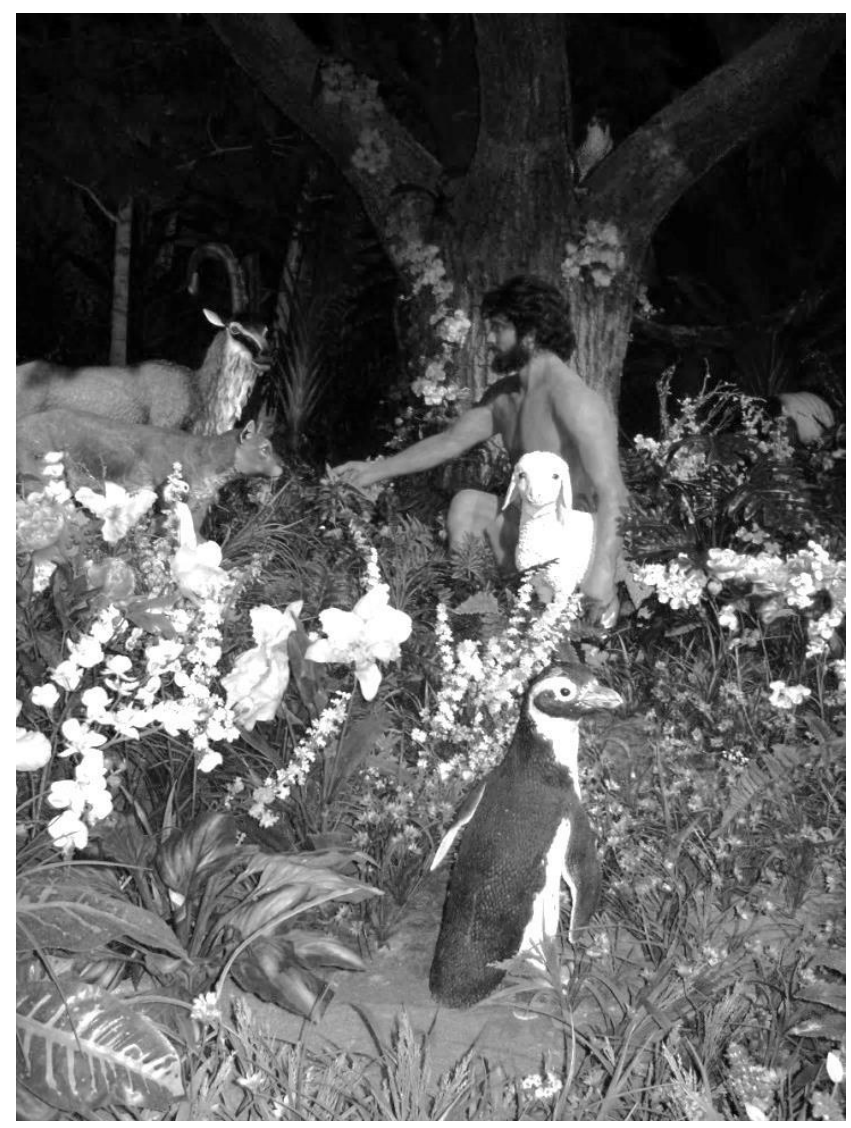

Photo 11. The scene above shows Adam in the Garden of Eden with a sheep, penguin, and other modern species of animals. What cannot be seen from this angle, but located only a few feet away are a chimpanzee and a kangaroo. (Photo: S. Watkins)

Also of note in this exhibit are two trees-one is identified as the Tree of Life and the second is the Tree of the Knowledge of Good and Evil. Both trees contain fruit which has been fictionalized. ${ }^{502}$ In the case of the Tree of the Knowledge of Good and Evil, grapes are pictured growing on the tree. On the Tree of Life, a reddish-orange fruit,

${ }^{502}$ The Tree of the Knowledge of Good and Evil contains grapes which grow in some kind of fictitious pods. I have written an article that addresses part of this phenomenon which will be published in The Fourth R: An Advocate for Religious Literacy (due out in the March/April 2013 issue). I will deal further with this fictionalization in the dissertation. 
somewhat similar in shape to a mango, is presented. The Garden of Eden has a jungle feel to it, although when one scrutinizes the details of this ecosystem, it doesn't quite match with any jungle I have ever encountered.

The last scene in the Creation section pictures the naked couple, Adam and Eve, in a pool of water under the Tree of the Knowledge. Located in the branches of the tree is a sinister looking serpent. The snake is also fictionalized as it is presented with fins of some sort protruding from the sides of its head (pictured below).

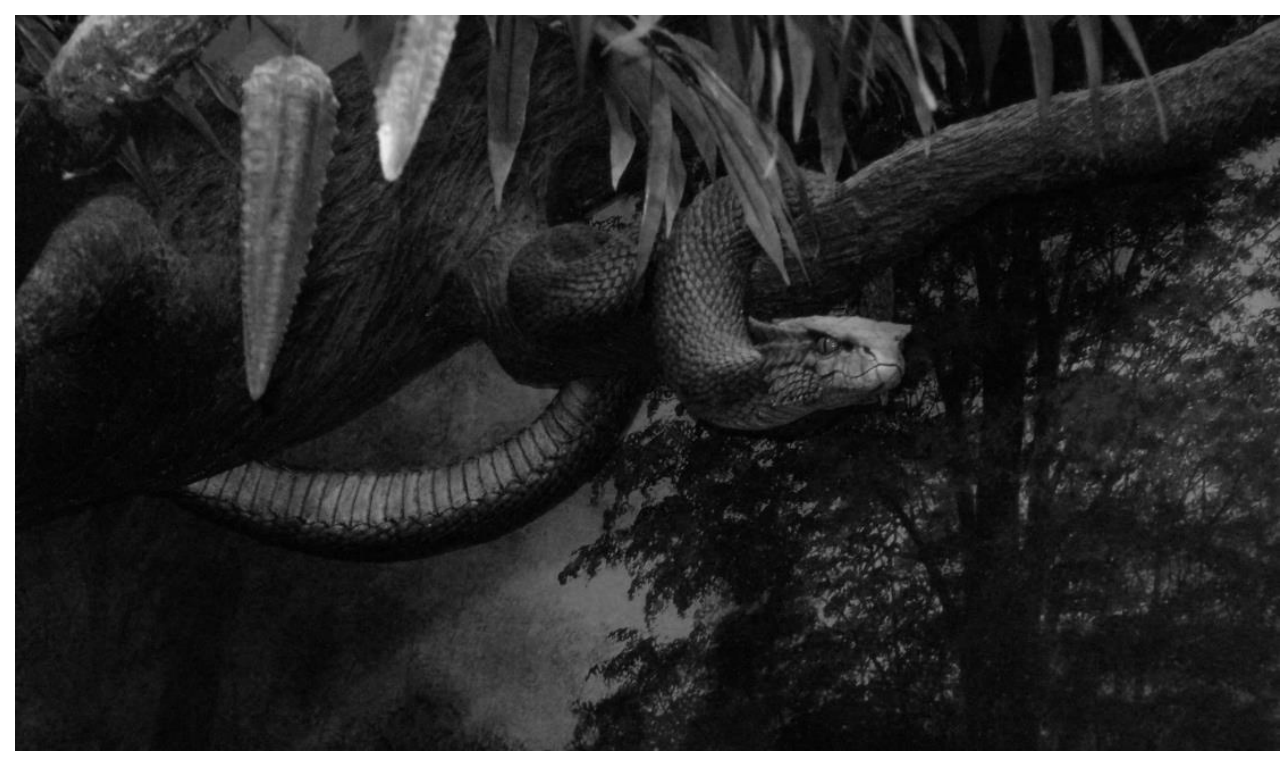

Photo 12. The fictionalized serpent in the Tree of Knowledge. (Photo: S. Watkins)

The scene of Adam and Eve insinuates the coming fall into sin. However, the Corruption section technically begins in the Cave of Sorrows. As one leaves the scene of Adam and Eve, another dark and evil looking path leads to the Cave of Sorrows. This next section is another extremely negative and emotive exhibit.

As a precursor to the terrible world of corruption, the visitor sees a door with numerous locks and the words "The World's Not Safe Anymore" scratched into the door 
(see photo below). The door resembles a feature in a haunted house. But the connection between the Fall in Eden to all forms of evil—moral and physical—is the main point in the Corruption section.

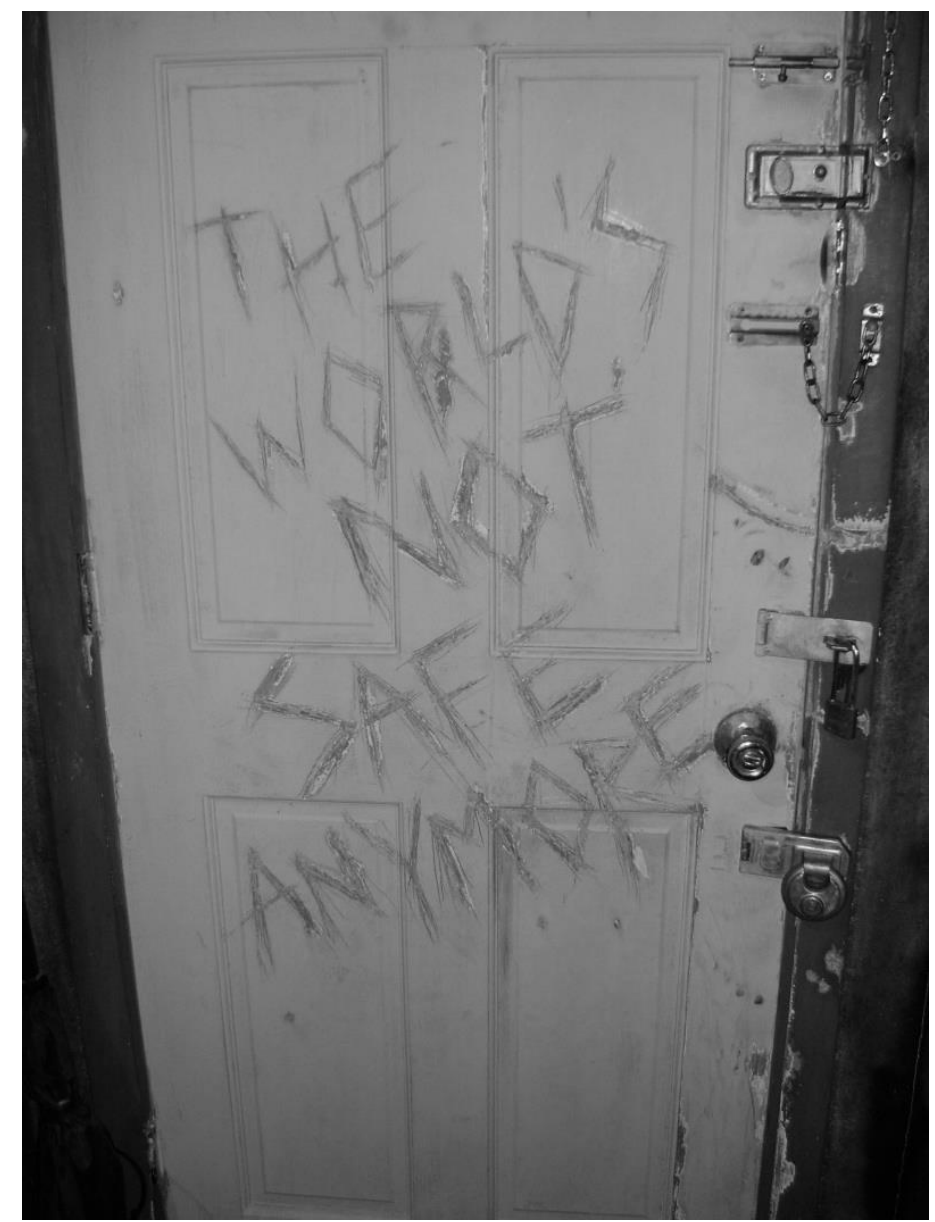

Photo 13. This door comes just after the depiction of the Serpent and of Adam and Eve's transgression. (Photo: S. Watkins)

The ominous looking door is the last item the visitor sees before entering the Cave of Sorrows. This Cave is probably the most difficult and disturbing scene in the entire museum. The Cave portrays all sorts of scenes that show physical and moral evil (Photos $7 \& 8$ ) with sounds piped in through speakers and video screens toward the back of the room. As is obvious from the large, black-and-white display board photos, the 
transgression of Adam and Eve - and by extension all of humanity - has led to every form of corruption and disaster on planet earth.

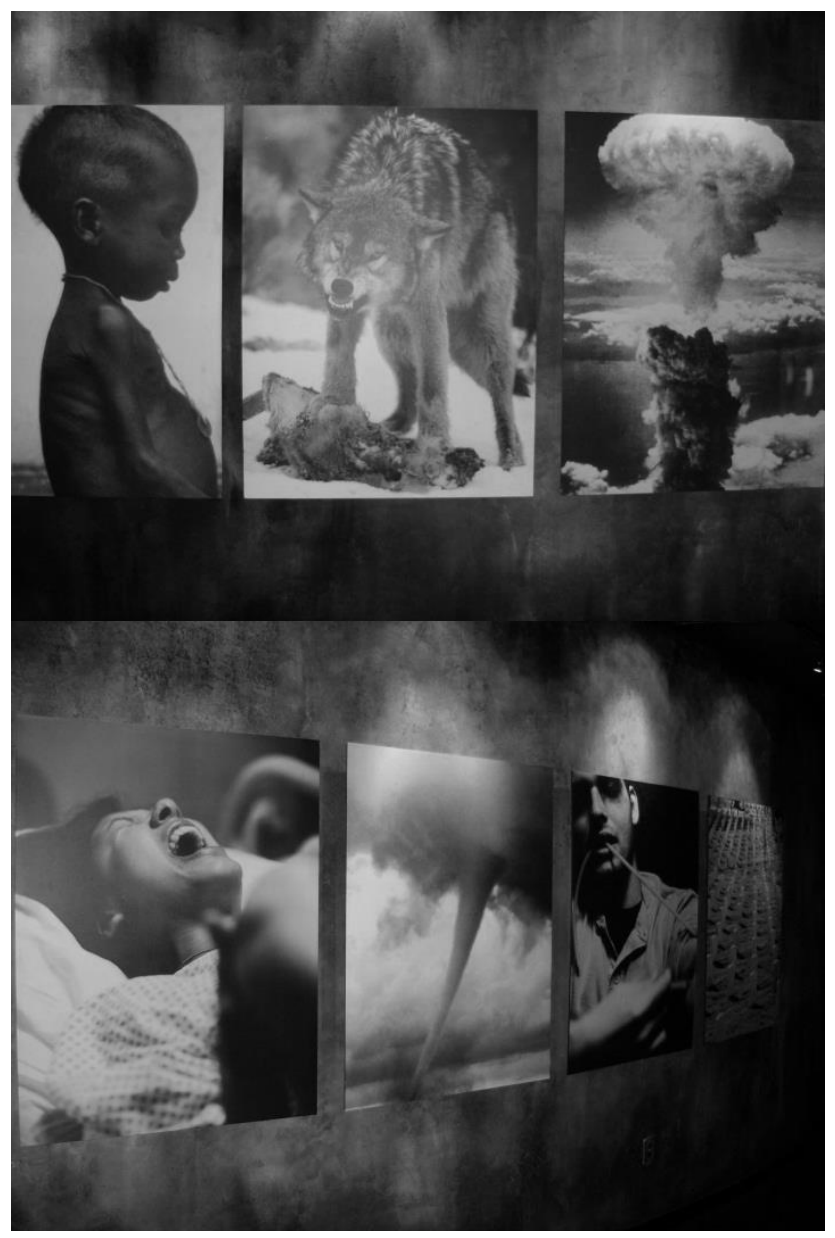

Photos $14 \& 15$. Two of the display board photos in the Cave of Sorrows. (Photo: S. Watkins)

Starvation, predatory animals, nuclear weapons, difficulty in childbirth, natural disasters, drug abuse, and a line of skulls from Pol Pot's Cambodia are shown as a direct result of Adam and Eve's sin. A verse that is cited numerous times throughout the CM is Romans 5:12 — "Therefore, just as through one man sin entered the world, and death through sin, and thus death spread to all men, because all sinned." I will deal with this interpretation at length in the dissertation. Here, I would simply note that this connection between the 
Romans verse - interpreted in a narrow fashion — and the literalized fall of Adam is one of the most important premises used to support the CM's closed hermeneutic approach. As the visitor moves through this dimly lit room, sounds of machine guns, screams, marching formations of Hitler's armies, and plane crashes accompany video images of these same scenes on the video screens toward the exit of the Cave of Sorrows. Something I have noted before is that, with the exception of the tornado, complications in childbirth, and animal predation, nearly every other scene comes from the modern world. This is an intentional move to form a multi-sensory connection between the fall and the troubles of the modern world. The CM attempts to explain any problem in the world as a direct result of the fall.

Exiting the Cave of Sorrows, the visitor returns to a pre-patriarchal scene in which Adam and Eve, now clothed in animal skins, sacrifice a lamb on a stone altar. Eve is shown crying with her hands raised in anguish. Adam stands behind a particularly bloody portrayal of the sacrifice. The next scene shows animals (dinosaurs in this case) tearing one another apart, followed by Cain murdering his brother Abel. There is a scene showing a hairy and unkempt man using a hoe to weed out his garden plot. A placard notes that "thorns and thistles" are also part of God's curse on the earth. Before leaving the Corruption section, an animatronic Methuselah speaks to visitors from inside a tent. His message is that since he has lived nearly an entire millennium, he can tell the story from Adam to Noah. He warns of the coming catastrophe of Noah's flood because people continued to be excessively sinful. This section narrates several passages from Genesis 4 and 5 . 
In terms of floor space the next section, Catastrophe, is the largest section of the Main Exhibits. The Catastrophe section tells the story of Noah from Genesis 6-9. The first portion of the exhibit is an enormous, scale cross-section of the ark. This begins a highly stylized portrayal of a rather sophisticated wooden ark. Pictured in this scene are Noah, his three sons, Shem, Ham, and Japheth, and numerous laborers working diligently to build this gigantic boat. Based on biblical details in Genesis 6, the museum claims that the scale section represented here is only one percent of the size of their estimates for Noah's ark.

Catastrophe contains detailed and elaborate depictions of every conceivable issue involved with how a literal ark could have transported two of every living creature on earth. Cages, food caches, excrement disposal, living quarters, and nearly every detail of life on the ark are addressed here. I have noted that this exhibit, more than any others I have studied, contains far more extra-biblical interpretation than others. The imaginative aspects of this area go beyond the detail in Genesis 6-9. One way to conceptualize the approach here is that it becomes a type of Christian Midrash. ${ }^{503}$ The amount of imaginative artistry and calculated details is staggering. For example, moveable drawers below certain animal cages illustrate how manure may be collected and disposed of in all sections of the ark (please see Photo 16).

${ }^{503}$ Midrash is a Jewish form of interpretation and explanation of portions of the Hebrew Bible. Midrash expands upon the text by adding stories that amount to both extrapolations from what is contained in the text as well as ideas that fill out the missing parts. I am indebted to my colleague, Professor Art Dewey, of Xavier University, for making this connection between the CM exhibits and Midrash. 


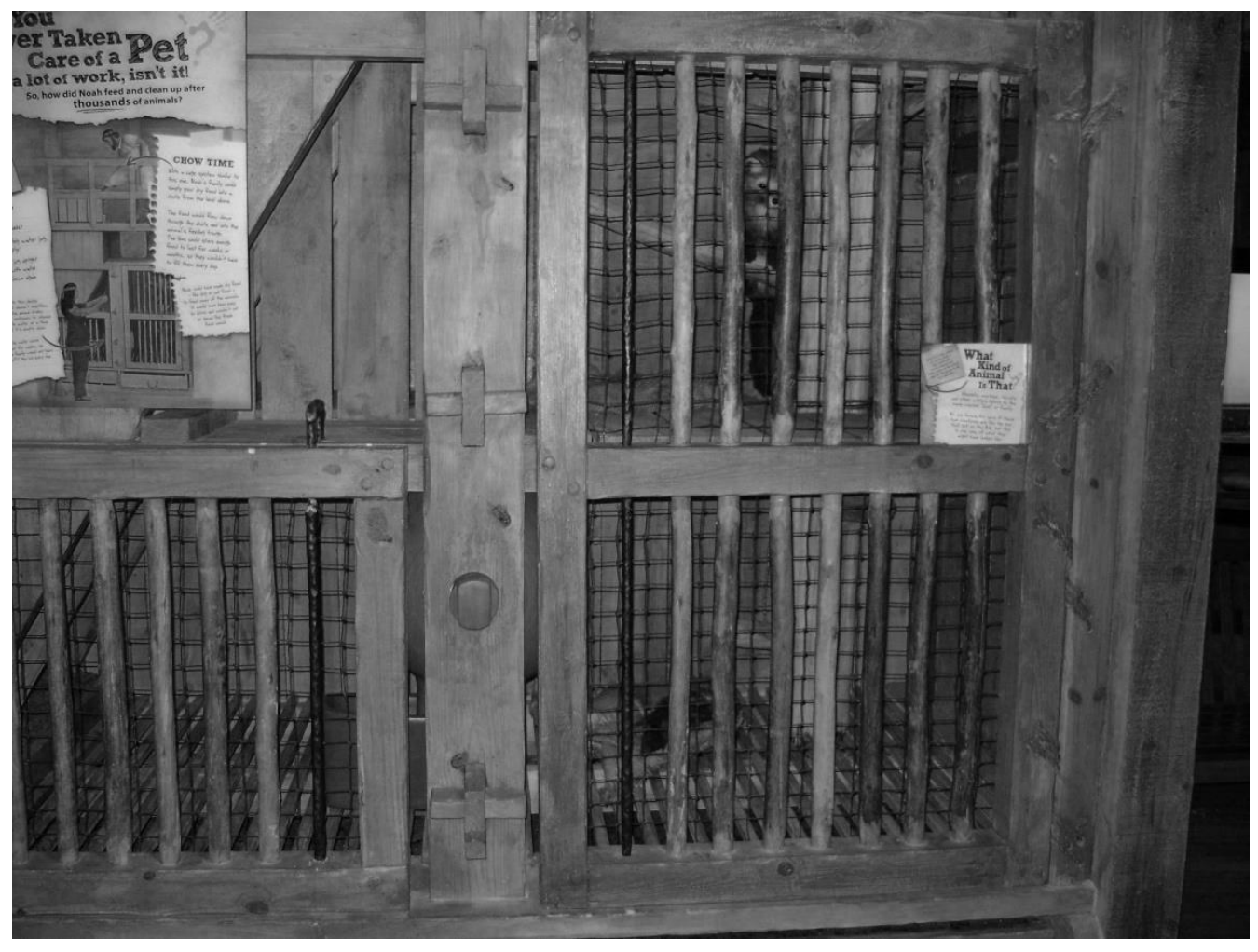

Photo 16. Animal cages on the ark including slats in the bottom of the cage to allow manure to fall into the retractable repository below. Photo: S. Watkins

Photo 16 does not show the drawer at the bottom, but these can be pulled out by visitor's to show the feasibility of how such a manure removal system would actually work. My research has shown that much of this detail is not original work done by the $\mathrm{CM}$ alone, but comes from more extensive publications by the Institute for Creation Research (ICR) in San Diego. One source contains most of the interpretations of Noah's ark at the CM. ${ }^{504}$

The visitor gets a sense of the realism of this alleged ark. The exhibit goes to great lengths to harmonize Early Bronze Age technology with a sophisticated and seaworthy craft that could negotiate the roughest sea states one could imagine. It should be

${ }^{504}$ This book is over three-hundred pages and includes a seventy-six page bibliography. I have not found a single interpretation of the ark as it is presented at the $\mathrm{CM}$ which does not originate in this work. John Woodmorappe, Noah's Ark: A Feasibility Study (El Cajon, CA: Institute For Creation Research, 1996). 
mentioned that the CM interprets Noah's flood to have been both an actual historic event and global in scope. Thus, this ark must have been an amazingly stable vessel for the time period under consideration.

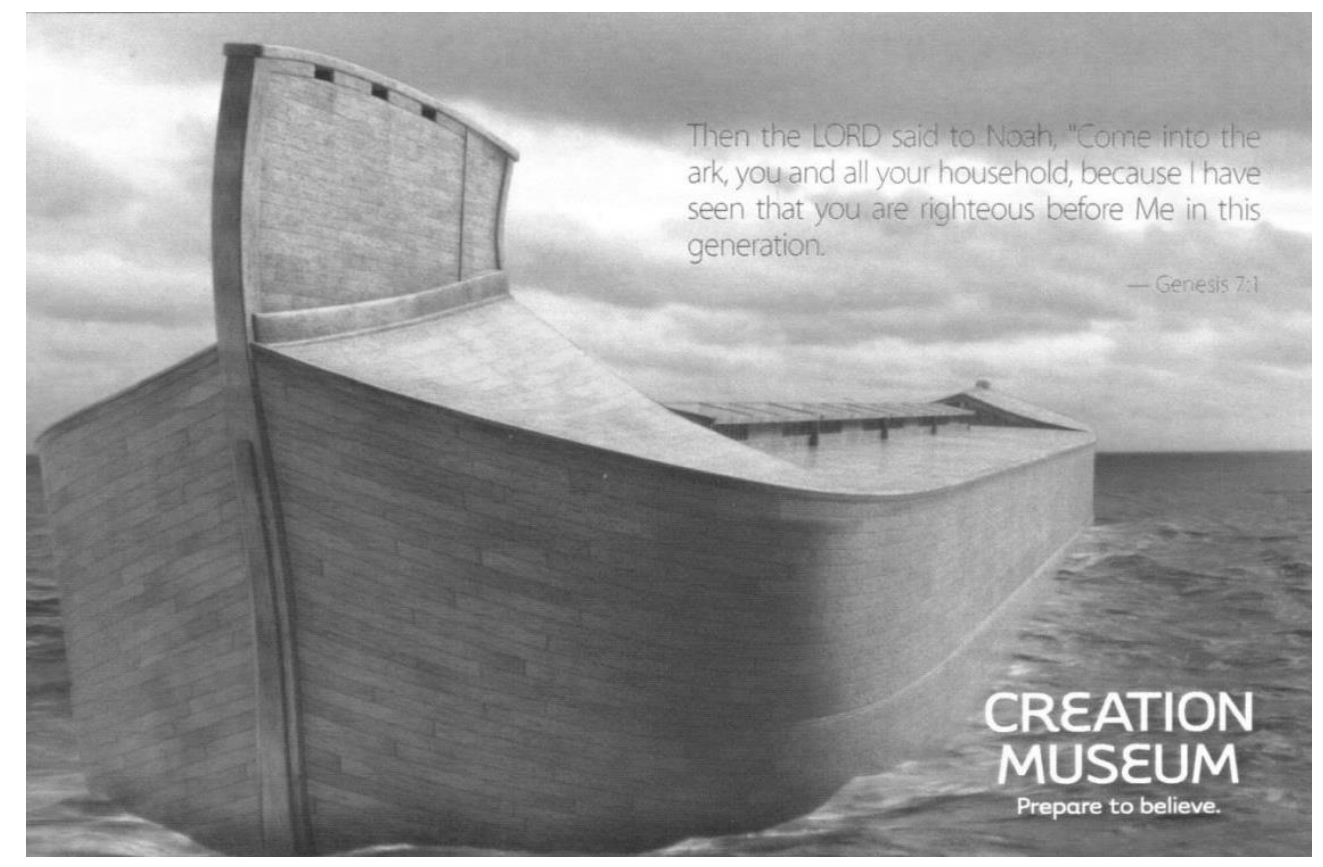

This image comes from a postcard that I purchased at the CM. This version of Noah's Ark is the current interpretation presented at the CM (Copyright 2008, Answers in Genesis).

Notice the realism in the artist's rendering of the ark. Gone are the folksy, Sunday school book pictures of a cartoon ark with giraffe necks protruding from windows. This boat appears sea worthy and stable. Additionally, this is the same image that is being promoted in the effort to raise money for the proposed Ark Encounter, an amusement park in nearby Grant County, Kentucky.

The visitor moves from the Ark Construction room to the Voyage of the Ark room. Each room narrates a realistic version of the construction and journey of Noah's ark. Following the Voyage of the Ark display is another large room titled Flood Geology. 
This room provides the leading YEC apologetic arguments for the fossil record. Once more, the basic arguments derive from the work of the Institute for Creation Research (ICR). More specifically, the pioneering work of Henry Morris and John Whitcomb's The Genesis Flood is the basis for these ideas. ${ }^{505}$ The basic approach has not changed much since its inception in the late 1950s and early 1960s. Flood geology may be summarized by the explanation that a global flood (i.e. Noah's flood) was responsible for the geologic rock strata, fossils, and terrain features such as the Grand Canyon. Known also as “catastrophism," flood geology attempts to account for sedimentary fossils as well as a radical change in topography from an original supercontinent or Pangaea. The difference is that the $\mathrm{CM}$ alleges that this supercontinent broke apart in the flood approximately five-thousand years ago, rather than the scientific academy's view of a gradual break-up beginning two-hundred million years ago.

One of the most striking displays in the Flood Geology room is the representation of an enormous floating forest (see Photo 10). A curved display board contains this artistic rendering of a massive, ancient forest floating on the ocean surface. The scene is dramatically presented with perfect lighting and gorgeous blue and green colors. I have found this piece of artwork to be among the most fascinating aspects of design and presentation in the CM.

505 John C. Whitcomb and Henry M. Morris, The Genesis Flood: The Biblical Record and its Scientific Implications (Phillipsburg, NJ: Presbyterian and Reformed Publishing, 1961). 


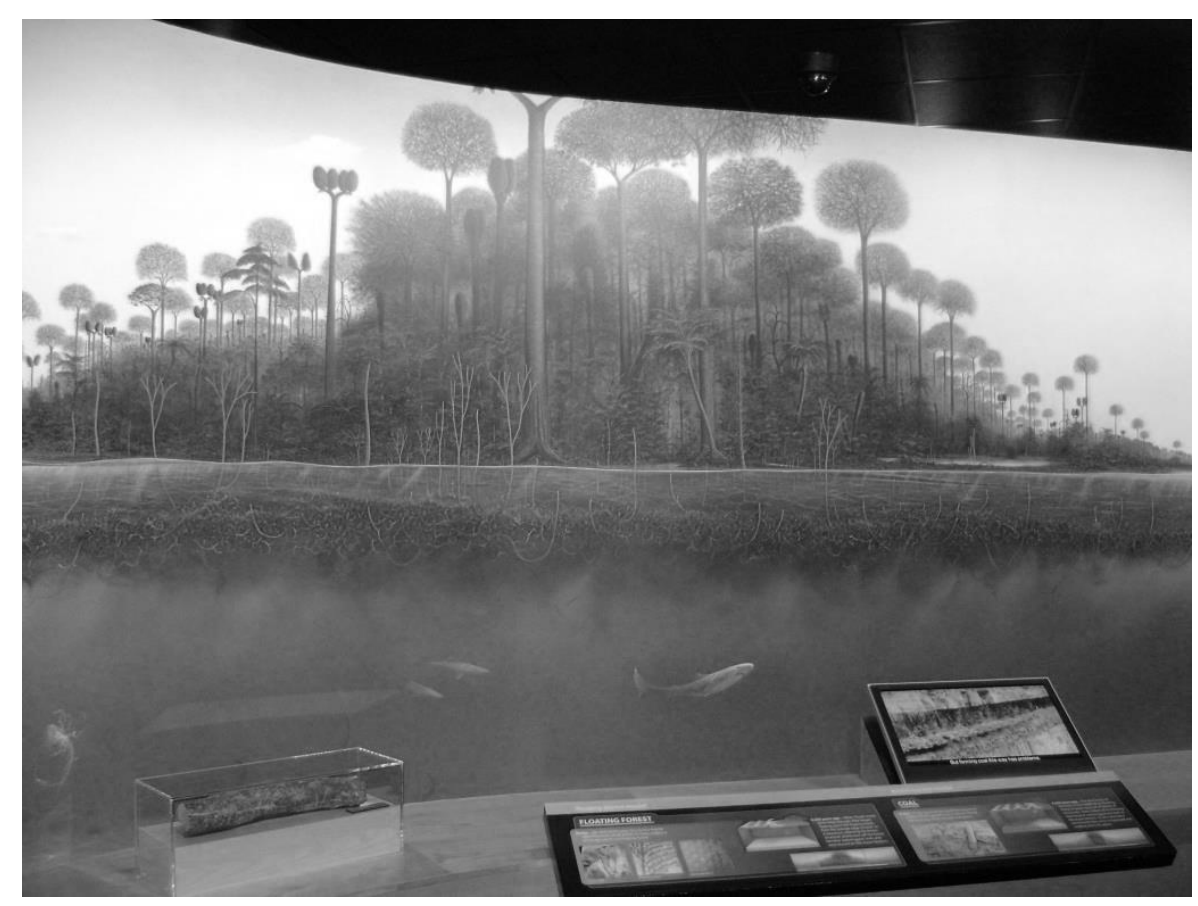

Photo 17. The photo above shows one-third of the entire display board containing the floating forest. (Photo: S. Watkins)

YEC depends heavily on this concept of floating forests. Two scientific requirements demand an explanation that may only be met by this assertion-fossil fuel deposits and animals reaching distant continents that are surrounded by water (e.g. Australia). According to flood geology, there must have been massive floating forests that were rapidly compressed under the extreme pressure of a global flood in order to form such large reservoirs of coal and oil deposits. Secondly, there must be a vehicle for the transport of land animals over thousands of miles of ocean in order for the dispersal of all the animals from the ark. Floating forests is the answer to these YEC conundrums. ${ }^{506}$

${ }^{506}$ I found several references to science articles that actually studied the phenomenon of floating forests. One of these is Professor Paul A. Moody of the University of Vermont. Moody's book Introduction to Evolution (New York: Harper, 1953) examines the phenomenon of floating islands (or forests). However, there are numerous problems with the way in which flood geologists and YEC use the floating forests to explain fossil fuel and land animal migration. 
This is another example of elaborate explanations that have nothing to do with specific biblical texts.

The Flood Geology room is dramatically lit, with sophisticated display boards, video screen, and touch screen computer monitors. From a distance, the overall impression of this room is as up-to-date and impressive as any museum I have visited. The devotion of space and resources to the ark and to Flood Geology is crucial for YECs. Without a catastrophic flood, there does not appear to be any way to explain geologic strata or the fossil record. In fact, it is worth noting that The Genesis Flood is viewed by scholars as the birth of Young Earth Creationism. ${ }^{507}$

The fourth " $\mathrm{C}$ " is Confusion - a relatively short section devoted to the narrative of Genesis 11 and the account of the Tower of Babel. Decorated in an ancient Mesopotamian style, this room explains where all of the different races of humans came from. The CM distances itself from the term "race" as it seeks to demonstrate that all humans are descendants from Adam and Eve, and later, from the three sons of NoahShem, Ham, and Japheth. The logic proposed here is that because all humans are derived from the same prototypical couple, there really is no racial issue. We are one big related family. Differences in skin color, language, facial features, and anything else associated with race and ethnicity resulted from the spreading-out of people from the Tower of Babel. The dispersion was caused by God's miraculous feat of making this once unified group of people — i.e. all speaking the same language — to speak different languages.

${ }^{507}$ Ronald L. Numbers, The Creationists: The Evolution of Scientific Creationism (Berkeley: University of California Press, 1992), ${ }^{507}$ Eugenie C. Scott, Evolution vs. Creationism: An Introduction $2^{\text {nd }}$. Ed. (Berkeley: University of California Press, 2006), and Arthur McCalla, The Creationist Debate: The Encounter Between the Bible and the Historical Mind (New York: Continuum, 2006). 
Eventually, this human diaspora led to pockets of isolated people with shared languages and physical traits.

Also included in Confusion is a connection between evolution and racism. This is not atypical for YECs. Social Darwinism and eugenics have been used in numerous publications in an attempt to demonize evolution. As explained at the CM, evolutionary theory leads to assuming some humans are more highly evolved than others, hence racism. Further, an erroneous connection is made between evolution and social Darwinism and eugenics. As Eugenie Scott has documented, these ideas are more associated with Herbert Spencer and genetics than with the theory of evolution. ${ }^{508}$ These ideas arose mostly in the post, World War I era.

The Confusion exhibit is relatively short and contains placards and video screens indicative of most other sections in the Main Exhibits. Based on Genesis 11, the twofold purpose of Confusion is that of, a) describing where so many different ethnic and cultural groups came from, and b) to connect evolution as a cause of racism and other politically charged social issues (eugenics, euthanasia, genetic manipulation). The overall feeling in this exhibit is somewhat mixed. Some aspects are positive and cheerful while others are dark and negative. For example, a flat screen monitor shows a short film that interprets Genesis 11. In the film, humanity is presented as corrupt as the Tower of Babel is an example of the folly and pride of all people. When God caused languages to be confused, scenes of fighting, darkness, and mayhem are presented. On the other hand, this room is decorated in an attractive Mesopotamian style. In attempting to counter racism, one display board features people from all over the world who are mostly portrayed with

\footnotetext{
${ }^{508}$ Eugenie C. Scott, Evolution vs. Creationism: An Introduction, $2^{\text {nd }}$ Ed. (Berkeley: University of California Press, 2009), 97-99.
} 
happy expressions and most are smiling. The people are all attractive and dressed in their various traditional ethnic clothes. The room is not brightly lit, but it does have a certain mellow, neutral feel to it —unlike the overwhelming negativity of the Cave of Sorrows or Graffiti Alley.

The last three "C"s of the Main Exhibit - Christ, Cross, and Consummation — are all joined into three final rooms. One of these rooms is The Last Adam Theater where a twenty-minute film presents the evangelical Gospel message. In this film the message of Jesus and his mission of salvation is connected to the story of Genesis. The inference is that not believing in the CM's literal Genesis account is equal to not truly believing the Gospel message. One of the ways in which this film connects Jesus to Genesis is by the title, The Last Adam. In other words, because of the first Adam's fall into sin, the human race is hopelessly lost. Thus it was the job of the Last Adam (a typological reference to Jesus from 1 Corinthians). The film also emphasizes the significance of Christ's crucifixion in typical evangelical candor. Consummation, as it is presented in the film, is the pre-millenial viewpoint that Christ will return to carry out a severe judgment on the non-believers (meaning anyone other than Christians) in addition to remaking the world into a type of restored Eden. The last three C's are all included in the film. At one time, there had been a small chapel in this section for those desiring to pray or be counseled. More recently, this chapel was converted into a children's book reading room. It has always struck me as odd that the main parts of Christianity (at least Christ and Cross) are limited to the smallest treatment and the least amount of floor space in the entire museum. 
After Christ, Cross, and Consummation the visitor proceeds to the Palm Plaza. This plaza area is well lit and is usually accompanied by the aroma of freshly brewed coffee which may be purchased at a central kiosk. Artificial palm trees are accompanied by pillars that form a cardo creating a Mediterranean ambience. There are numerous fossil displays inside glass display cases lining the walls surrounding the plaza. Palm Plaza is connected to two other exhibits: the Dragon Theater and the Dinosaur Den. ${ }^{509}$

The Dragon Theater runs a short, eleven-minute video titled Dinosaurs and Dragon Legends. This video makes the assertion that dinosaurs not only roamed the earth in the last five-to-six thousand years, but also that worldwide legends about mythic dragons are actual references to dinosaurs. Moreover, two creatures from the book of Job, transliterated Behemoth and Leviathan, are said to be biblical accounts of dinosaursBehemoth being possibly a sauropod dinosaur and Leviathan being a sea-going plesiosaur. The video relies on the testimony of Harvard trained paleontologist Kurt Wise. ${ }^{510}$ Wise argues that descriptions of Behemoth and Leviathan from the book of Job sound strikingly like two actual dinosaurs. Wise's arguments comprise the majority of the short film. Legends about dragons are the CM's attempt to help explain that there were extra biblical accounts of dinosaurs living with humans.

Adjacent to the Dragon Theater is the Dinosaur Den. The Den contains sixteen life-size replicas of numerous dinosaurs - a few of which are animatronic. There is only one reconstructed triceratops skeleton. Such skeletons are more typical of what one

${ }^{509}$ The Dragon Theater is also referred to as "Dragon Legends Theater" in CM publications. I make this note because the map attached to this document uses Dragon Theater, which I will also use for consistency.

${ }^{510}$ I intend to interview Dr. Wise, who is a faculty member at The Southern Baptist Seminary in Louisville. Dr. Wise was a student of the late Stephen Jay Gould and is arguably the most credentialed Young Earth Creationist in the world. 
would find at museums of natural history. Placards line the short walkway through the dinosaur displays. These placards contain the CM's revisionist interpretations concerning dinosaurs.

Toward the back of the Palm Plaza are two lecture halls. The first, Morris Whitcomb Lecture Room, is named after the co-authors of The Genesis Flood. On the other side of the hallway is The Discovery Hall. Both rooms are attractively decorated and well-lit rooms that may be used as lecture halls or classrooms. These rooms are the locations where various lectures are given throughout the day. For example, Dr. Georgia Purdom (Ph.D. in molecular genetics, Ohio State University) and Dr. David Menton (Ph.D. in biology, Brown University) are the most frequent speakers on a variety of scientific topics. I have rarely visited the $\mathrm{CM}$ when one of these two people failed to be advertised as the day's featured speaker.

There are no other areas adjacent to the Palm Plaza that serve as featured attractions for visitors. A hallway leads guests to a staircase that returns to the Dragon Hall Bookstore. From the bookstore, the visitor has the option to return to the Main Hall or to exit the $\mathrm{CM}$ and return to the parking lot. The bookstore includes hundreds of print publications - primarily ones that are published with the imprint Master Books. Located in Green Forest, Arkansas, Master Books is a division of New Leaf Publications and is devoted almost entirely to YEC causes, especially those of Ken Ham and other authors closely affiliated with the CM. The bookstore is well decorated and it contains everything from toy dinosaurs to children's literature and hundreds of apologetic books. The bookstore provides homeschool material, DVDs, magazines, and numerous other gift sundries and trinkets. 
From the Main Hall, there are two other featured attractions. The Stargazers Room is a planetarium that shows several different films dealing with various YEC interpretations of the cosmos. According to articles by scientists, the planetarium is stateof-the-art and contains factual data on the universe - such as the distance of galaxies and other conventional aspects of

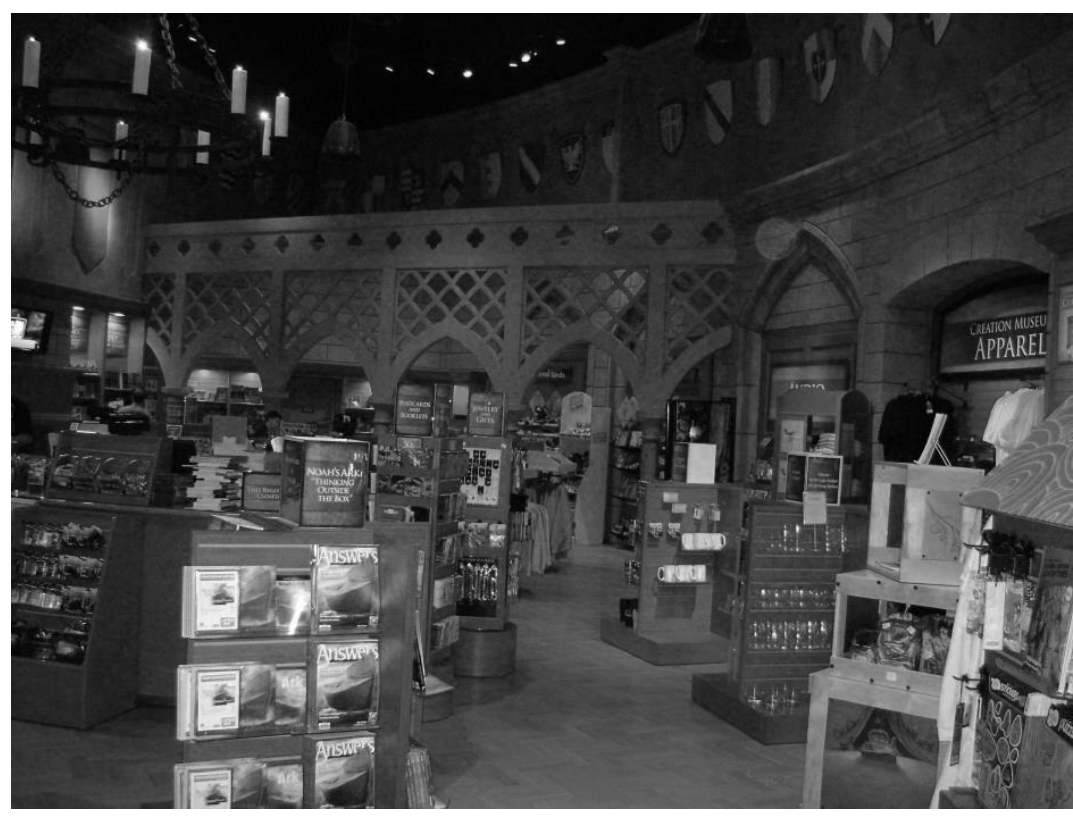

Photo 18. One part of the Dragon Hall Bookstore

modern cosmology. ${ }^{511}$ The most common film featured in the planetarium is titled "Created Cosmos." The film is narrated by Jason Lisle, an astrophysicist who no longer works for the CM. The film contains a few YEC references to a revisionist view of modern cosmology. For example, Lisle makes a claim that an abundance of Blue Supergiants in spiral galaxies proves that these galaxies are much younger than "secular

${ }^{511}$ Daniel Phelps, "The Anti-Museum: An Overview and Review of the Answers in Genesis Creation 'Museum," "Web article posted on the National Center for Science Education website(October 2008). http://ncse.com/creationism/general/anti-museum-overview-review-answers-genesis-creationmuseum (accessed November 21, 2010) 
scientists" claim. But according to scientists who have written on the topic, this is a strange and unsupported claim. ${ }^{512}$

On the opposite side of the Main Hall is a special effects theater (also referred to as Men In White Theater in the map, below). The theater contains seats that vibrate and squirt bursts of water in sequence with certain parts of the film. During one episode portraying Noah's ark, the seats tilt and water bursts forth to induce the sensation of being on the ark. The only other time I have experienced a similar type of theater was at King's Island theme park in an attraction called Days of Thunder (NASCAR) experience. The seats moved and shook to give the sensation of driving a race car. The film played daily in the special effects theater is titled "Men In White." The film is said to be a satire involving two hipster looking young men dressed in white jumpsuits. The pair is presented as the angels Gabe and Mike (Gabriel and Michael). The twenty-three minute film is intended to answer some philosophical questions that come from an animatronic female mannequin named Wendy. Wendy is having existential anxiety about the meaning of life and whether or not God exists. So Gabe and Mike burst on the scene to answer Wendy's questions and to poke fun at higher education and science along the way. While the film is supposed to be light-hearted and funny, there are some rather vitriolic portrayals of academics and scientists as bumbling and out-of-touch.

The last main attraction in the CM is Noah's Café, a full service restaurant designed to look like the inside of the ark. Adjacent to the café is a patio overlooking the scenic lake which fronts the CM. Located outside is also the Lakeside Grill where visitors can purchase burgers and other fast food choices. The Lakeside Grill is open only during

\footnotetext{
${ }^{512}$ Mark Isaak, The Counter-Creationism Handbook (Berkeley: University of California Press, 2007), 184-85.
} 
warm weather periods. The outside patio provides tables where diners can enjoy the beautiful scenery of the botanical gardens on the other side of the lake.

Nature Trails are an advertised attraction throughout the grounds of the CM. Attractively landscaped paths contain lily ponds, roped bridges, a butterfly and hummingbird garden, waterfalls, and a Carnivorous Bog Garden (containing carnivorous plants). In my opinion, the gardens of the $\mathrm{CM}$ are the most aesthetically appealing part of the entire facility - especially during spring and summer.

A trail through the garden leads visitors to the final big attraction, the Petting Zoo. Always popular with children, the Petting Zoo contains some interesting species of animals that fit a particular creationist message. At my last visit I found camels, llamas, donkeys, goats, sheep, turkey, rabbits and a few animals that were cross breeds. One of the cross breeds is a zonkey — a cross between a zebra and a donkey. The other mixed breed was a zorse - a cross between a zebra and a horse. The implication here is subtle but the CM maintains that these cross breed examples show how all the animals in the modern world could have come from an original pair of proto animals which God created on the day that animals were made. In other words, all dogs came from a proto pair of dogs and the same is true for every other species of animal. One reason why this claim is made is because the total number of current species of every animal could never have fit on the ark, given the literal dimensions recorded in Genesis. According to one of their publications, "The zonkey, the Zorse, and donkeys all belong to the horse kind. This helps people understand there can be great variation within each kind of animal God created. And it was animal kinds that Noah took aboard the ark - a dog kind, a cat kind, a 
horse kind, etc." ${ }^{513}$ Like many other petting zoos, visitors may purchase pelletized food to feed to the domesticated animals. During warm weather, camel rides are also available for an extra cost.

In conclusion, this narrative summary has provided a basic overview of the main components of the CM. There are a number of proposed changes and added exhibits which I will deal with in the dissertation. To date, I have not found anyone at the CM with the title "Curator." Further, I could not find any ongoing research projects typical of most museums. Only a small fraction of the space at the CM contains actual skeletons or fossils as the vast majority of exhibits consist of media, film, and animatronics. Also lacking, were any scholarly scientific or biblical studies sources in the bookstore. Part of my analysis will deal with the importance of what is left out at the CM as well as what is included. I mention these observations here because I feel that what is missing from the $\mathrm{CM}$ is important - and sometimes even more so - than what is presented.

${ }^{513}$ Journey Through the Creation Museum (Green Forest, AZ: Master Books, 2008), 91. 


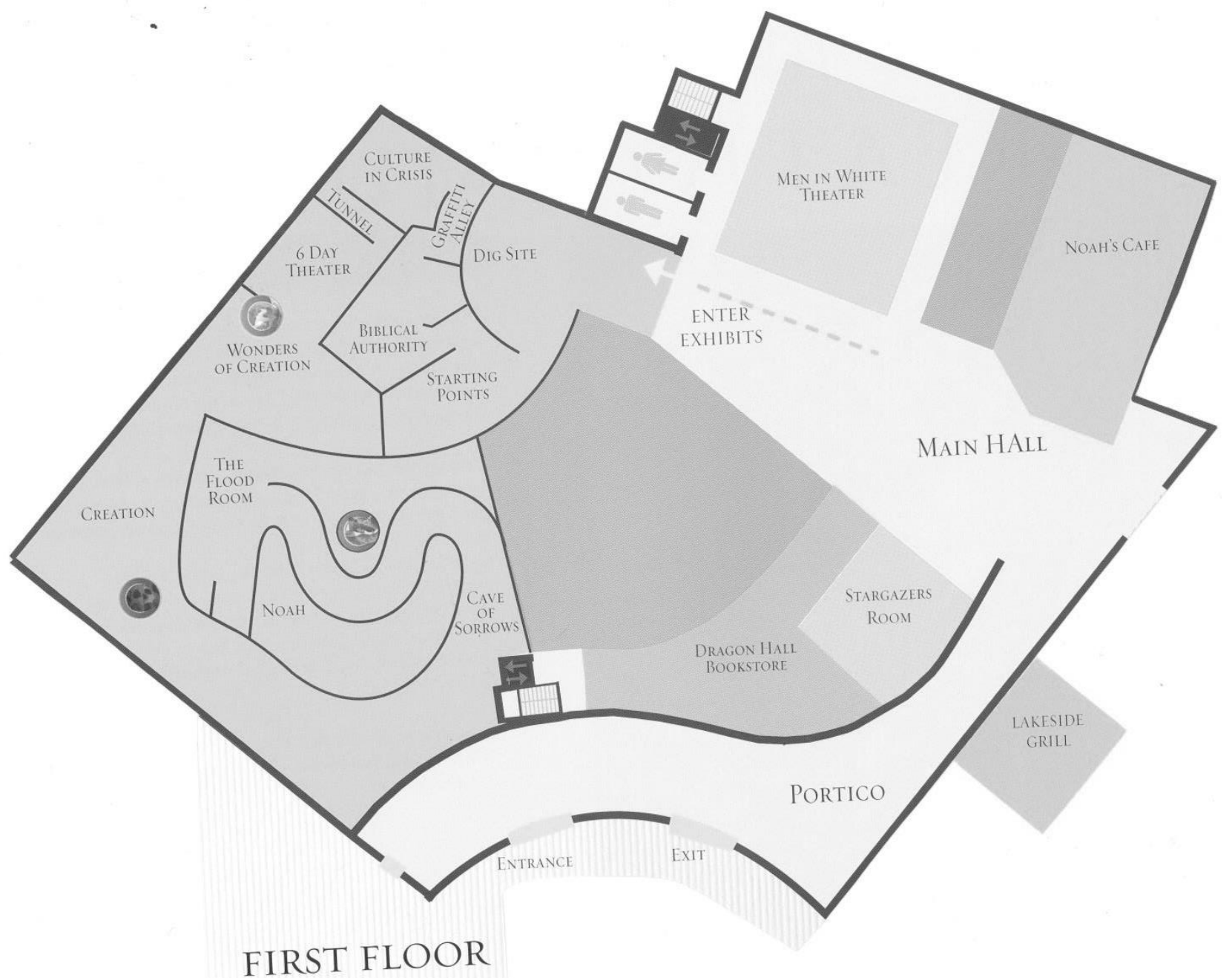

Map 1: First Floor of the Creation Museum. ${ }^{514}$

${ }^{514}$ Ibid, 4. 


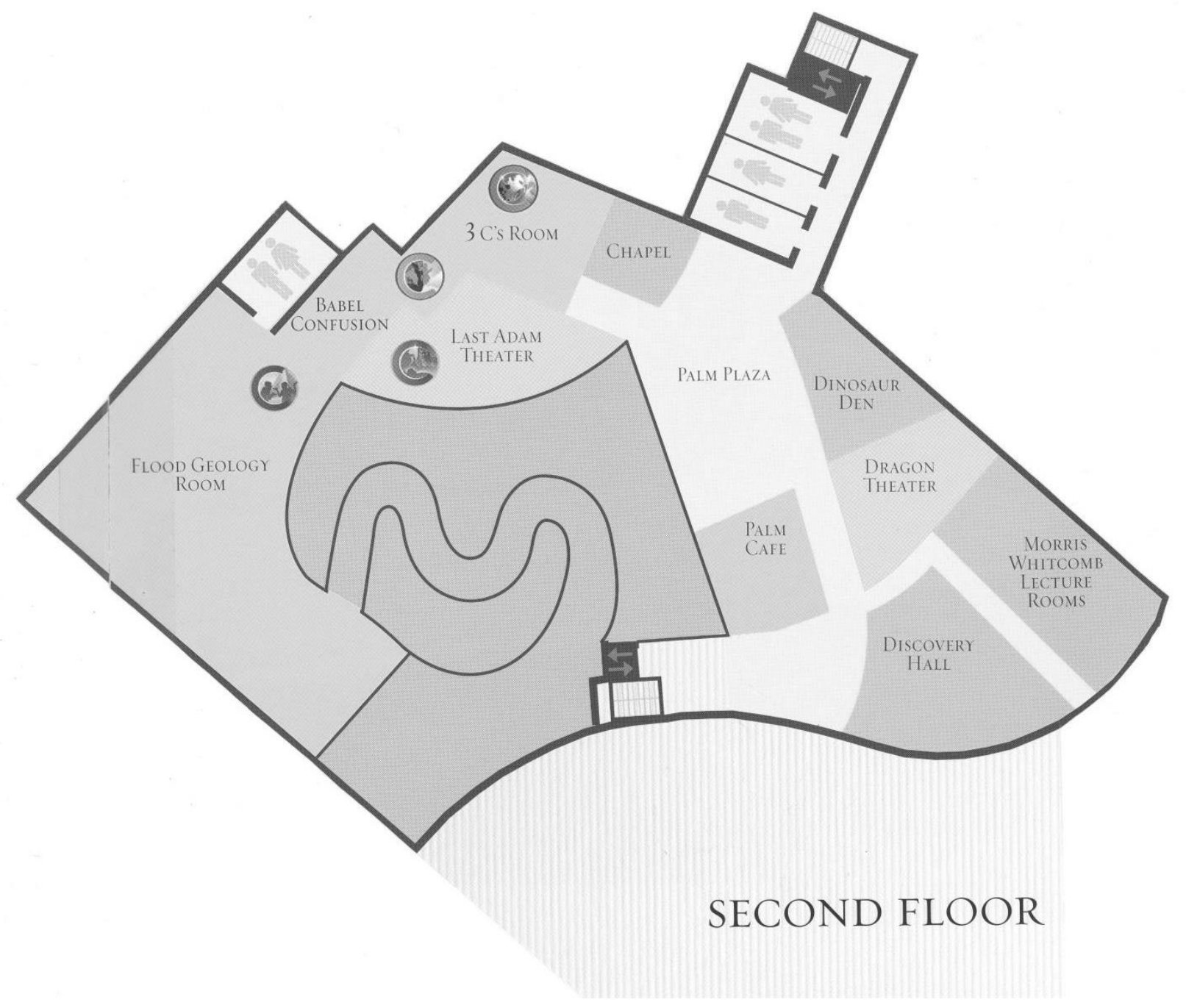

Map 2: Second Floor of the Creation Museum. 


\section{CURRICULUM VITAE}

NAME: $\quad$ Steven Mark Watkins

ADRESS: Department of Sociology, Anthropology, and Philosophy

Nunn Drive

Northern Kentucky University

Highland Heights, KY 41099

DOB: $\quad$ Lexington, Kentucky - February 12, 1968

EDUCATION

\& TRAINING: $\quad$ B.A., History

Northern Kentucky University

1993-96

M. Div., Theology

The Master's Seminary, Los Angeles

1997-2000

Ph.D., Humanities

University of Louisville

2008-2014

AWARDS: W. Frank Steely Award in History/Social Studies for Outstanding Senior, NKU, 1996-97

"Best Article" in Perspectives in History Journal, NKU, 1996-97

History Alumni Society Book Award, NKU, 1994

Dean’s Scholarship, NKU, 1995-96

Honorable Mention in USA Today “All-USA Academic Team”, 1996

First Place in the Alpha Chi Essay Contest, NKU, 1996

Golden Key National Honor Society Scholarship, NKU, 1996 
Certificate of Appreciation from NKU's History and Geography

Department \& Phi Alpha Theta, 1996

PROFESSIONAL SOCIETIES: The American Academy of Religion

Phi Alpha Theta

Sixteenth Century Society

Society of Biblical Literature

The Humanities Education and Research

Association

The Westar Institute

Kentucky Philological Society

PUBLICATIONS: "Dragon Snakes and Fictitious Grapes: What Happens When Myths are Literalized," The Fourth R: An Advocate for Religious Literacy (March-April, 2013)

“Touch,” The Kentucky Monthly (November, 2012)

"Fear," published in The Dos Passos Review (Vol. 7 No. 2 Spring 2011)

"Parachute Jump," in Stories from a Soldiers Heart (Multnomah Publishers, 2003)

"The Battle of Agincourt," Perspectives in History, Journal of Alpha Beta Phi Chapter of Phi Alpha Theta (1995-1996)

\section{NATIONAL MEETING PRESENTATIONS:}

Presenter, "The King James Version as Cultural Icon: A Tool for Monarchs and Fundamentalists," Research paper delivered at the Sixteenth Century Society and Conference, Cincinnati, Ohio, October 25, 2012.

Presenter, "Shyamalan's The Village as a Paradigm for Teaching Utopian and Fundamentalist Boundaries," Research paper delivered at the Communal Studies Association Conference, New Harmony, Indiana, October 2, 2011. 
Presenter, "Leibnizian Optimism: History Reasesses Voltaire's Pangloss," Research paper delivered at the Phi Alpha Theta National Biennial History Conference, San Diego, California, January $7^{\text {th }}, 2010$.

\section{REGIONAL MEETING PRESENTATIONS:}

Presenter, "A Sociolinguistic Approach to Communicative Dysfunction in Religious Speech Communities," Research paper delivered at the Kentucky Philological Association $37^{\text {th }}$ Annual Conference, Richmond, Kentucky, March 5, 2010.

Presenter, "Pro Deo et Patria...For God and Country: Chaplains in the U.S. Military," Northern Kentucky University Military History Lecture, Spring 2009.

Presenter, "The New Sophistry: Young Earth Creationism as a Lesson in Rhetoric, Not Hermeneutics," Research paper delivered at The American Academy of Religion Southeast Conference for the Study of Religion, Chapel Hill, N.C. March 14, 2009.

Presenter, "Are Special Operations Troops 'Expendable:' The Debate over How to Deploy Un-conventional Units,” Northern Kentucky University Military History Lecture, Fall 2006

Presenter, with Dr. James A. Ramage, "Irregular Warfare: The Parallel Tactics of Mosby's Rangers and Navy SEALS," Northern Kentucky University Military History Lecture, Fall 1996 